RENÊ GUILHERME DA SILVA MEDRADO

RETALIAÇÃO COLETIVA E TEORIA DE FORMAÇÃO DE ALIANÇAS NO SISTEMA DE SOLUÇÃO DE CONTROVÉRSIAS DA ORGANIZAÇÃO MUNDIAL DO COMÉRCIO

TESE DE DOUTORADO

PROF. ORIENTADOR: PROF. DR. ALBERTO DO AMARAL JÚNIOR DEPARTAMENTO DE DIREITO INTERNACIONAL

FACULDADE DE DIREITO DA UNIVERSIDADE DE SÃO PAULO SÃO PAULO - 2011 


\title{
RETALIAÇÃO COLETIVA E TEORIA DE FORMAÇÃO DE ALIANÇAS NO SISTEMA DE SOLUÇÃO DE CONTROVÉRSIAS DA ORGANIZAÇÃO MUNDIAL DO COMÉRCIO
}

\begin{abstract}
Tese apresentada à Faculdade de Direito da Universidade de São Paulo (USP) como requisito parcial à obtenção do título de Doutor em Direito Internacional, sob a orientação do Professor Doutor Alberto do Amaral Júnior.
\end{abstract}

Candidato: Renê Guilherme da Silva Medrado

Faculdade de Direito da Universidade de São Paulo São Paulo - 2011 
Banca Examinadora:

(2) 
À Reny, esposa valorosa, companheira e incentivadora das tantas etapas, percorridas em aliança.

Aos meus filhos João Guilherme e Helena, por serem inspiração, mesmo sem entenderem o porquê e para quê disso tudo. 


\section{AGRADECIMENTOS}

Ao Prof. Dr. Alberto do Amaral Júnior, pela percuciente, incentivadora, serena e sempre pertinente orientação.

Aos Profs. Drs. Umberto Celli Jr. e Fernando Dias Menezes de Almeida, pelo encorajamento crítico ao projeto de tese apresentado.

Aos meus queridos pais, Gézio e Raquel Medrado, pelo apoio irrestrito e pelo incentivo constante ao longo dos anos.

Aos amigos colaboradores, Marcelo Kramer, pelas instigantes discussões sobre paisagens e afins; Geraldo Vidigal Neto, pelas argutas conversas e hábil assistência no processo de revisão; e, Rodrigo Carneiro e Diógenes Gonçalves, parceiros de escritório, pela amizade e apoio de sempre.

A Deus, acima de todas as coisas, por um ciclo que se fecha. 
"[D]eveloped countries, viewing things from the perspective of their role as potential defendants, are quite comfortable with membership in a legal system where they can hurt others but some others cannot really hurt them". (Robert E. Hudec (1993), p. 42)

"[Y]ou may cover whole skins of parchment with limitations, but power alone can limit power" (John Randolph, citado por Hans J. Morgenthau (2006), p. 181)

"[I]n theory, the relation of alliances to the balance of power is simple enough. Put affirmatively, states enter into alliances with one another in order to supplement each other's capability." (George Liska (1962), p. 26).

"[I]f there is any distinctively political theory of international politics, balance-of-power theory it is." (Kenneth N. Waltz (2010), p. 117). 


\section{i. ÍNDICE}

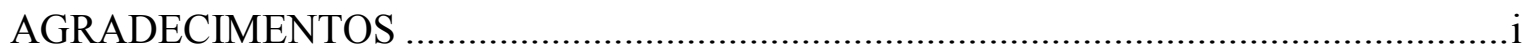

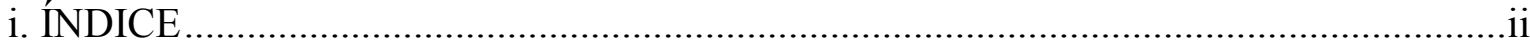

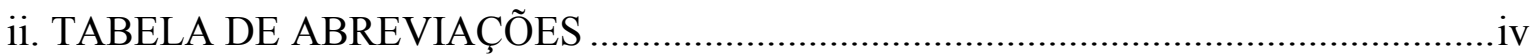

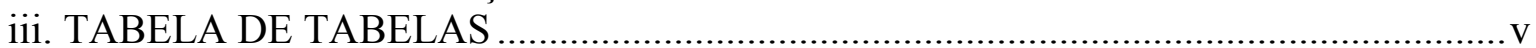

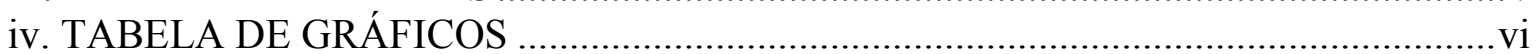

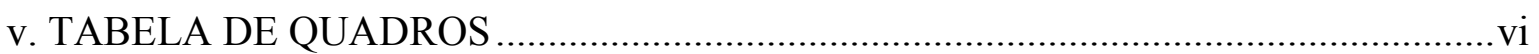

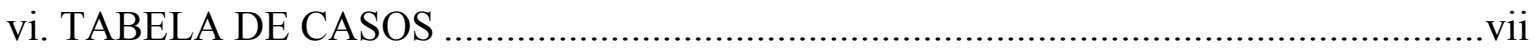

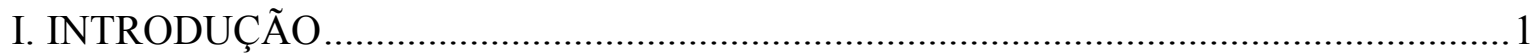

II. O DILEMA DO CUMPRIMENTO DAS RECOMENDAÇÕES DO OSC NO

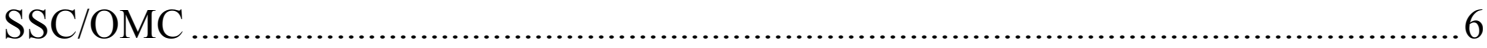

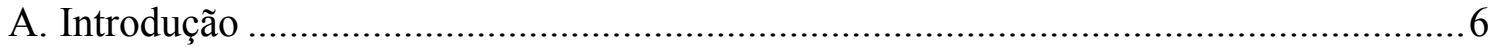

B. Breve Resumo sobre o Procedimento de um Contencioso perante o SSC/OMC .........7

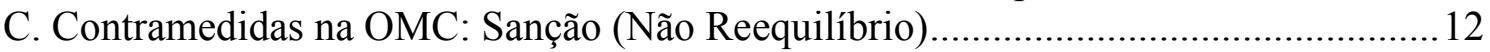

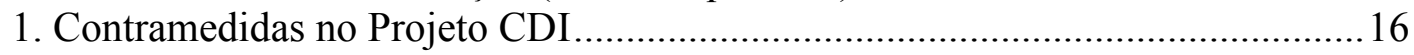

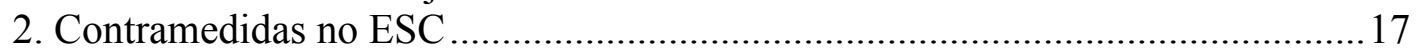

3. Contramedidas Aplicadas: Reequilíbrio ou Punição? ........................................22

D. Relatórios sobre a Natureza das Contramedidas: Arbitragens do Artigo 22.6 ...........24

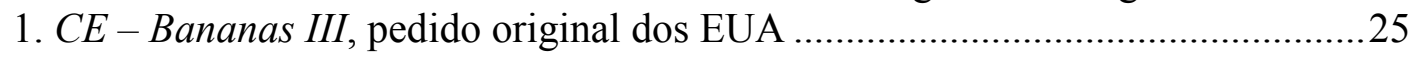

2. $C E-H o r m o ̂ n i o s$, pedidos originais de EUA e Canadá …...................................28

3. CE-Bananas III, pedido original do Equador ….............................................. 30

4. Brasil-Aeronaves, pedido original do Canadá .....................................................33

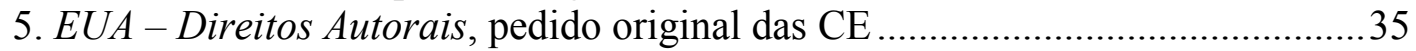

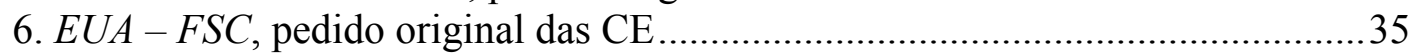

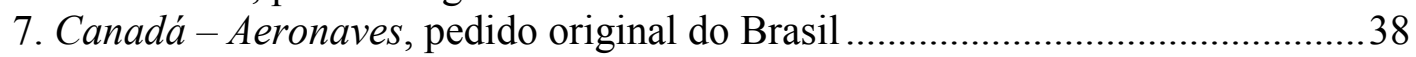

8. EUA - Lei Antidumping de 1916, pedido original das CE .................................40

9. EUA-Emenda Byrd, pedidos originais de Brasil, Canadá, CE, Chile, Coreia,

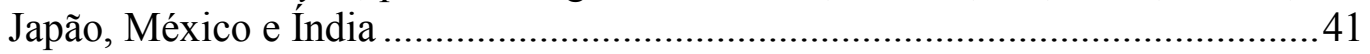

10. EUA - Jogos e Apostas, pedido original de Antígua e Barbuda.........................46

11. EUA - Algodão, pedido original do Brasil .......................................................49

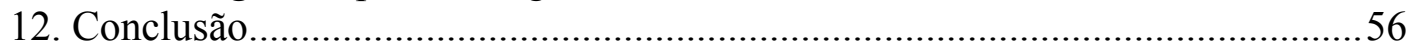

III. PROPOSTAS PARA SOLUÇÃO DO PROBLEMA DO COMPLIANCE NO

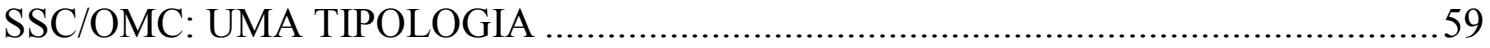

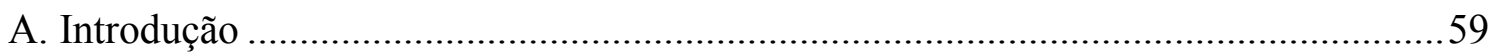

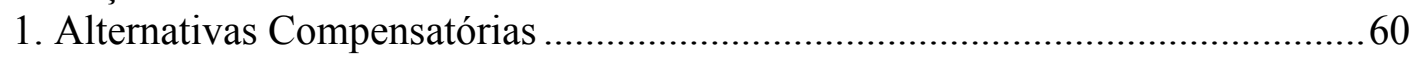

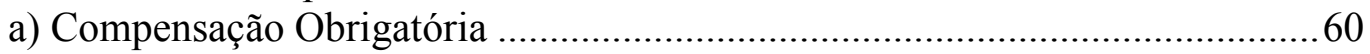

b) Compensação Monetária ........................................................................66

2. Abordagens Alternativas de Enforcement .......................................................66

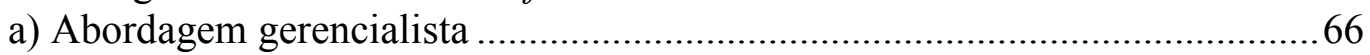

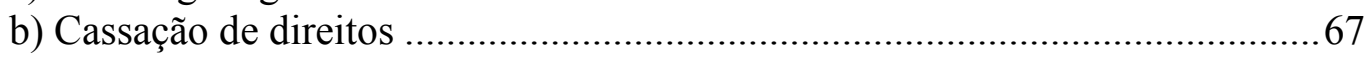

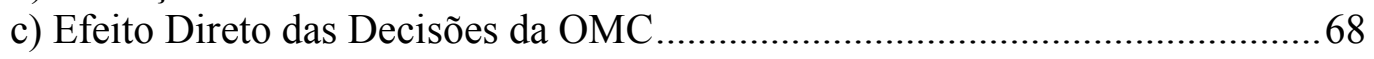

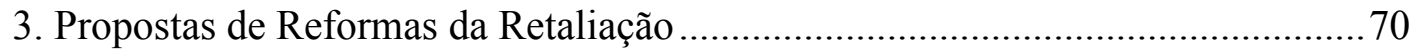

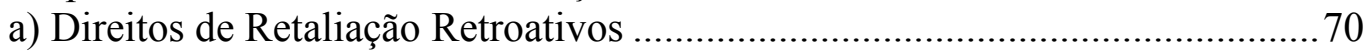

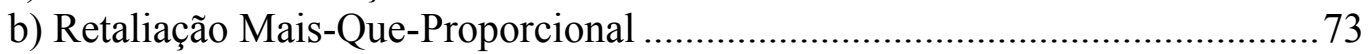

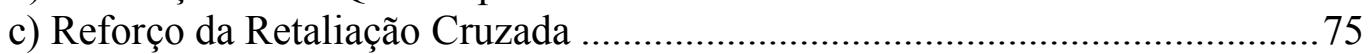

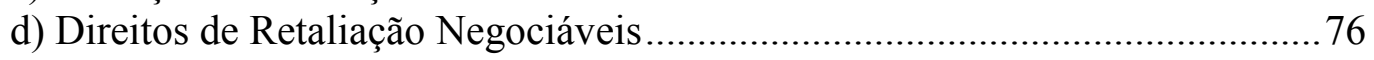




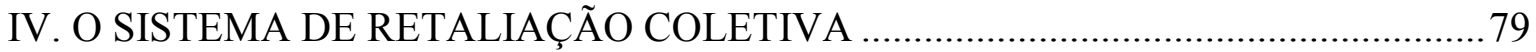

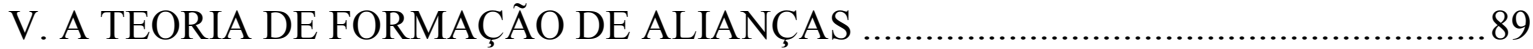

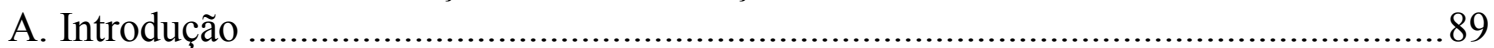

B. Autores Clássicos: Hans J. Morgenthau e George Liska .......................................... 91

1. Hans J. Morgenthau: O equilíbrio de poder e a formação de alianças ................ 91

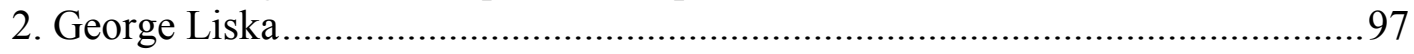

C. Estudos subsequentes aos clássicos: tentativas de sistematização e formalização ... 100

D. Kenneth Waltz (1979): Realismo estruturalista: A formação de alianças como

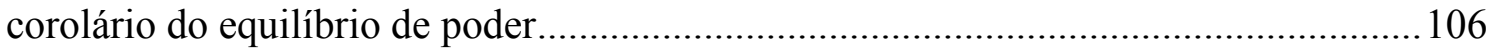

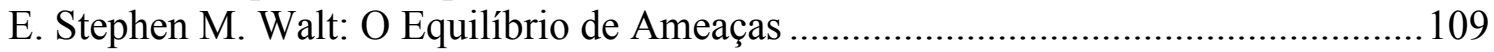

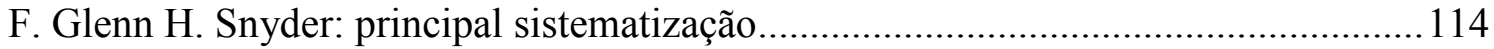

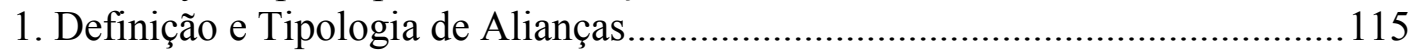

2. O Contexto Sistêmico das Alianças .................................................................... 116

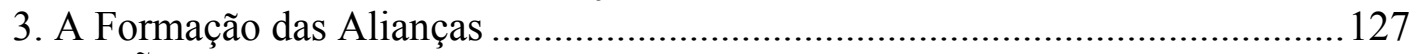

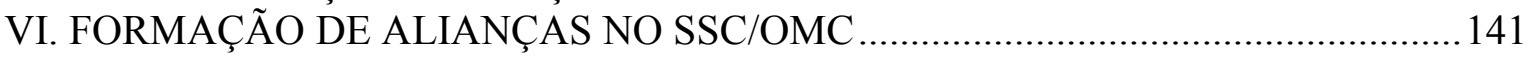

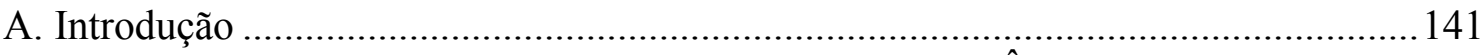

B. Identificação dos Fatores para Formação de Alianças no Âmbito do SSC/OMC .... 142

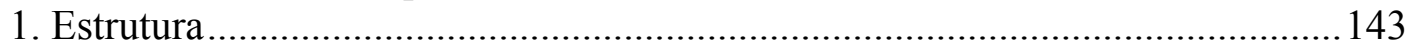

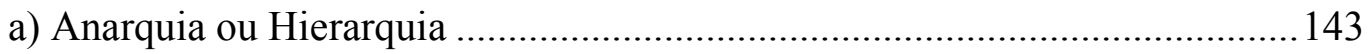

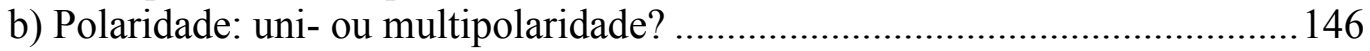

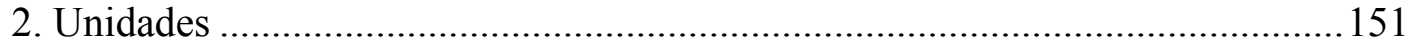

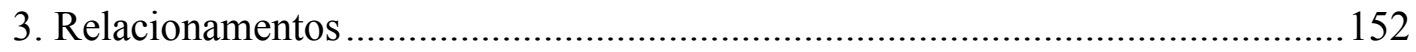

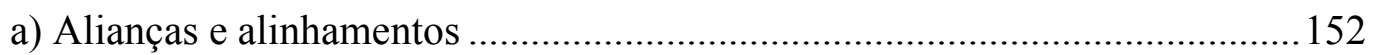

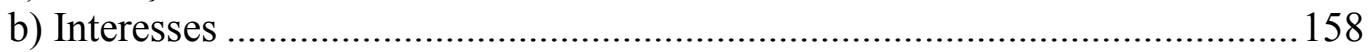

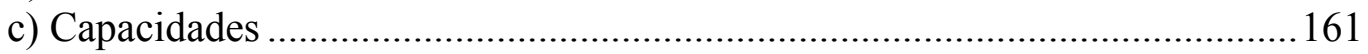

d) Aliança-Dependência (Interdependência) ................................................. 164

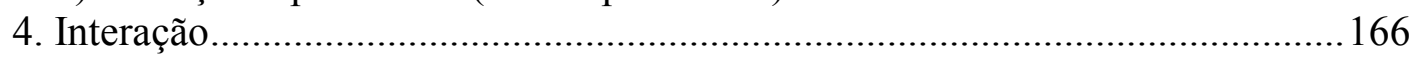

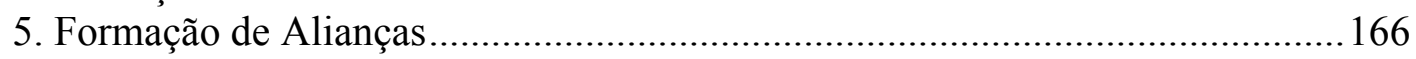

C.Aplicação da Teoria de Formação de Alianças às Situações Fáticas das Onze

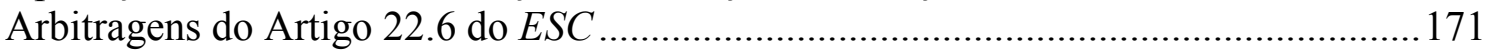

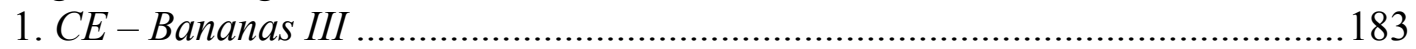

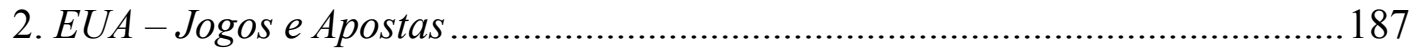

D. Considerações Finais sobre a Utilidade da Aplicação da Teoria de Formação de

Alianças, como Desenvolvida por Glenn H. Snyder, sobre o SSC/OMC .......................189

E. Teoria da Paisagem de Agregação e sua Aplicação ao SSC/OMC .................................192

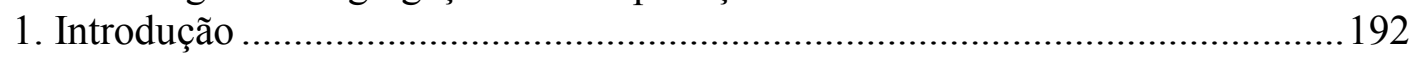

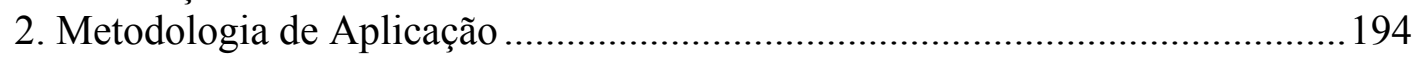

3. Aplicação aos Contenciosos CE - Bananas e EUA - Jogos e Apostas ..............196

VII. PROPOSTA NORMATIVA PARA INCORPORAÇÃO DE UM MECANISMO DE

RETALIAÇÃO COLETIVA NO SSC/OMC ...........................................................203

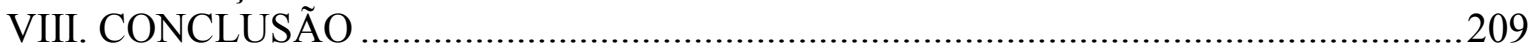

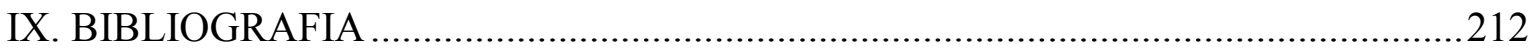

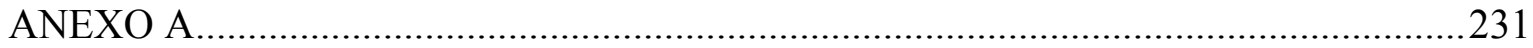

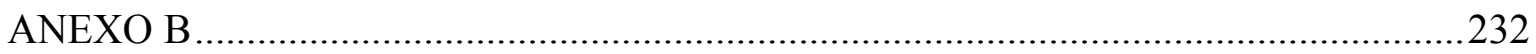

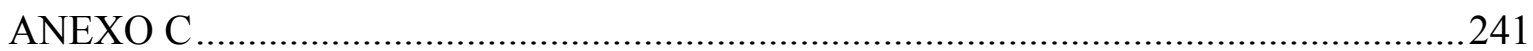




\section{ii. TABELA DE ABREVIAÇÕES}

\begin{tabular}{|l|l|}
\hline ASMC & Acordo sobre Subsídios e Medidas Compensatórias \\
\hline ACP-Países & Países da África, Caribe e Pacífico \\
\hline BRIC & Brasil, Rússia, Índia e China \\
\hline CE & Comunidades Europeias \\
\hline EC & Comunidades Europeias (sigla em inglês) \\
\hline EEC & Comunidade Economica Europeia (sigla em inglês) \\
\hline ESC & Entendimento sobre Solução de Controvérsias \\
\hline EU & União Europeia (sigla em ingles) \\
\hline EUA & Estados Unidos da América \\
\hline FMI & Fundo Monetário Internacional \\
\hline GATS & Acordo Geral sobre o Comércio de Serviços \\
\hline GATT 1947 & $\begin{array}{l}\text { Acordo Geral sobre Tarifas Aduaneiras e Comércio, assinado em 30 } \\
\text { de outubro de 1947 }\end{array}$ \\
\hline GATT 1994 & Acordo Geral sobre Tarifas e Comércio (Anexo do Acordo da OMC) \\
\hline ICTSD & International Centre for Trade and Sustainable Development \\
\hline IMF & Fundo Monetário Internacional (sigla em inglês) \\
\hline MERCOSUL & Mercado Comum do Sul \\
\hline NAFTA & Tratado Norte-Americano de Livre Comércio (sigla em inglês) \\
\hline OMC & Organização Mundial do Comércio \\
\hline OSC & Órgão de Solução de Controvérsias \\
\hline PMDs & Países Menos Desenvolvidos \\
\hline Projeto CDI & $\begin{array}{l}\text { Projeto de Artigos sobre a Responsabilidade dos Estados por Fato } \\
\text { Internacionalmente Ilícito }\end{array}$ \\
\hline PRT & Prazo razoável de tempo \\
\hline SPS & Acordo sobre a Aplicação de Medidas Sanitárias e Fitossanitárias \\
\hline SSC & Sistema de Solução de Controvérsias \\
\hline TBT & Acordo sobre Barreiras Técnicas ao Comércio \\
\hline TRIPS & $\begin{array}{l}\text { Acordo sobre Aspectos dos Direitos de Propriedade Intelectual } \\
\text { Relacionados ao Comércio }\end{array}$ \\
\hline UE & União Europeia \\
\hline US & Estados Unidos da América (sigla em inglês) \\
\hline WTO & Organização Mundial do Comércio (sigla em inglês) \\
\hline
\end{tabular}




\section{iii. TABELA DE TABELAS}

Tabela 1 - Objetivos das Contramedidas por Arbitragem

Tabela 2 - Ganhos Obtidos com Alianças

Tabela 3 - Maiores Usuários do SSC/OMC - "Casos Totais"

Tabela 4 - Unidades das Onze Arbitragens

Tabela 5 - Classificação das Unidades/Membros conforme Distribuição de

Capacidades

Tabela 6 - Classificação das Situações Fáticas conforme Desigualdades de Capacidades

Tabela 7 - Interesses Invocados pelas Partes no Caso CE - Bananas III

Tabela 8 - Energia Mobilizada no Caso CE - Bananas III

Tabela 9 - Energia Mobilizada no Caso EUA - Jogos e Apostas (com Retaliação

Coletiva Facultativa)

Tabela 10 - Energia Mobilizada no Caso EUA - Jogos e Apostas (com Retaliação

Coletiva Obrigatória)

Tabela 11 - Poderio Nacional de Maiores Usuários do SSC/OMC

Tabela 12 - Tipologia dos Interesses Invocados pelas Terceiras-Partes 
iv. TABELA DE QUADROS

\begin{tabular}{|c|c|}
\hline Quadro 1 & Capacidades Iguais \\
\hline Quadro 2 & Dois fracos, um forte \\
\hline Quadro 3 & Dois fortes, um fraco \\
\hline Quadro 4 & Três diferentes capacidades \\
\hline
\end{tabular}

v. TABELA DE GRÁFICOS

\begin{tabular}{|c|c|}
\hline Gráfico 1 & População x PIB (PPP) \\
\hline Gráfico 2 & Comércio Agregado \\
\hline Gráfico 3 & Distribuição de Capacidades \\
\hline
\end{tabular}




\section{vi. TABELA DE CASOS}

\section{OMC}

\section{Controvérsia}

European Communities - Regime for the Importation, Sale and Distribution of Bananas, iniciada em 5 de fevereiro de 1996

Canada-Certain Measures Concerning

Periodicals, iniciada em 11 de março de 1996

Brazil - Export Financing Programme for Aircraft, 19 de junho de 1996

Korea-Definitive Safeguard Measure on Imports of Certain Dairy Products, iniciada em 12 de agosto de 1997

Canada-Measures Affecting the Importation of Milk and the Exportation of Dairy Products, iniciada em 8 de outubro de 1997

United States - Tax Treatment for "Foreign Sales

Corporations", iniciada em 18 de novembro de 1997

Australia - Subsidies Provided to Producers and Exporters of Automotive Leather, iniciada em 4 de maio de 1998

United States - Anti-Dumping Act of 1916, iniciada em 4 de junho de 1998

United States of America - Certain Measures Affecting the Import of Cattle, Swine and Grain from Canada, iniciada em 25 de setembro de 1998

United States - Section 110(5) of the US Copyright Act, iniciada em 26 de janeiro de 1999

United States - Import Measures on Certain Products from the European Communities, iniciada em 4 de março de 1999

United States of America - Countervailing Duty Investigation with respect to Live Cattle from Canada, iniciada em 19 de março de 1999
DS31

Número Nome abreviado

DS27 CE-Bananas III

DS46 Brasil-Aeronaves

DS98 Coreia-Laticínios

DS103

DS108 EUA-FSC

DS126 Austrália-Couro Automotivo

DS136 EUA-Lei Antidumping de 1916

DS144

DS160 EUA-Direitos Autorais

DS165 EUA-Certos Produtos das CE 
Canada - Term of Patent Protection, iniciada em 6

de maio de 1999

United States of America - Reclassification of

DS180

Certain Sugar Syrups, iniciada em 6 de setembro de 1999

United States of America-Measures Treating

DS194

Export Restraints as Subsidies, iniciada em 19 de maio de 2000

United States - Continued Dumping and Subsidy Offset Act of 2000, iniciada em 21 de dezembro de 2000/ 21 de maio de 2001

United States of America - Section 129(c)(1) of the Uruguay Round Agreements Act, iniciada em 17 de janeiro de 2001

Canada-Export Credits and Loan Guarantees for DS222 Canadá-Aeronaves Regional Aircraft, iniciada em 22 de janeiro de 2001

United States of America - Preliminary

DS236

Determinations with Respect to Certain Softwood Lumber from Canada, iniciada em 21 de agosto de 2001

Argentina - Definitive Anti-Dumping Duties on DS241 Poultry from Brazil, iniciada em 7 de novembro de 2001

United States of America - Provisional AntiDS247 Dumping Measure on Imports of Certain Softwood Lumber from Canada, iniciada em 6 de março de 2002

United States of America - Final Countervailing DS257 Duty Determination with respect to certain Softwood Lumber from Canada, iniciada em 3 de maio de 2002

United States of America - Final Dumping Determination on Softwood Lumber from Canada, iniciada em 13 de setembro de 2002

United States - Subsidies on Upland Cotton, iniciada em 27 de setembro de 2002

Canada - Measures Relating to Exports of Wheat DS276 and Treatment of Imported Grain, iniciada em 17 de 
dezembro de 2002

United States of America - Investigation of the DS277 International Trade Commission in Softwood Lumber from Canada, iniciada em 20 de dezembro de 2002

United States - Measures Affecting the Cross-Border Supply of Gambling and Betting Services, iniciada em 13 de março de 2003

European Communities - Measures Affecting Trade in Commercial Vessels, iniciada em 3 de setembro de 2003.

United States of America - Determination of the International Trade Commission in Hard Red Spring Wheat from Canada, iniciada em 8 de abril de 2004

United States of America - Reviews of DS311 Countervailing Duty on Softwood Lumber from Canada, iniciada em 14 de abril de 2004

United States - Continued Suspension of Obligations in the EC-Hormones Dispute, iniciada em 8 de novembro de 2004

Canada - Provisional Anti-Dumping and DS338 Countervailing Duties on Grain Corn from the United States, iniciada em 17 de março de 2006

Brazil - Anti-dumping Measures on Imports of DS355 Certain Resins from Argentina, iniciada em 26 de dezembro de 2006

United States of America - Subsidies and Other DS357 Domestic Support for Corn and Other Agricultural Products, iniciada em 8 de janeiro de 2007

United States of America - Certain Country of DS384 Origin Labelling (Cool) Requirements iniciada em $1^{\circ}$ de dezembro de 2008

Dominican Republic - Safeguard Measures on DS415 Imports of Polypropylene Bags and Tubular Fabric, DS416 iniciada em 15 de outubro de 2010 


\section{Corte Permanente de Justiça Internacional}

Caso sobre a Fábrica em Chrozów (Alemanha v. Polônia), decisão de 13 de setembro de 1928, 1929 PCIJ, Série A, no. 17.

\section{Corte Internacional de Justiça}

Caso sobre Jurisdição em Matéria de Pesca (Reino Unido v. Islândia), julgamento do mérito, 25 de julho de 1974.

Caso sobre o Pessoal Diplomático e Consular dos Estados Unidos em Teerã (EUA v. Irã), julgamento do mérito, 24 de maio de 1980.

Caso sobre o Projeto Gabcikovo-Nagymaros (Hungria v. Eslovênia), julgamento do mérito, 25 de setembro de 1997.

\section{Tribunal de Justiça da União Europeia}

Processos apensos C-402/05 (Yassin Abdullah Kadi) e C-415/05 (Al Barakaat International Foundation), julgamento de 3 de setembro de 2008 (Grande Secção).

\section{Arbitragens}

Caso Naulilaa (Portugal v. Alemanha), 2 UN Reports Of International Arbitral Awards 1012 (Tribunal Arbitral Misto Germano-Português), decisão de 31 de julho de 1928.

Caso Acordo de Serviço Aéreo (EUA v. França), 18 R.I.A.A., p. 416, decisão do Tribunal Arbitral de 9 de dezembro de 1978. 


\section{INTRODUÇÃO}

Este trabalho tem por objeto analisar a viabilidade de implementação, no âmbito do sistema de solução de controvérsias (“SSC”) da Organização Mundial do Comércio (“OMC") (em conjunto, referidos simplesmente por "SSC/OMC"), de um mecanismo de contramedidas (retaliação) coletiva, à luz da aplicação da teoria de formação de alianças, a qual vem sendo amplamente desenvolvida na teoria de relações internacionais.

A adoção de um sistema de retaliação coletiva tem importância pela necessidade de se aprimorar os mecanismos de enforcement das decisões proferidas pelo Órgão de Solução de Controvérsias (“OSC”) da OMC. A proposta de sua adoção no SSC/OMC é relativamente conhecida, tendo tanto a doutrina estrangeira quanto a nacional já ventilado o assunto, concluindo, em geral, parecer ser um meio possível de aprimoramento do $\mathrm{SSC} / \mathrm{OMC}$.

Nesse sentido, a doutrina já superou a controvérsia de que contramedidas no âmbito do SSC/OMC constituem providências necessárias e apropriadas para induzir ao cumprimento ("induce compliance") das decisões do OSC, sendo de sua natureza atingir tal objetivo. Trata-se da própria função das contramedidas, como o próprio OSC, baseado em relatórios preparados por painéis e pelo Órgão de Apelação, tem consistentemente indicado.

Tal natureza encontra apoio na assertiva posta por vários doutrinadores de que o enforcement no regime internacional da OMC deve se basear em técnicas complementares, de gerenciamento (managerial theory) ou sancionatórias, por exemplo, amplamente abarcadas no Acordo da OMC. ${ }^{1}$ Nesse diapasão, o aprimoramento das técnicas sancionatórias deve servir, no mínimo, para que constituam ameaça crível a balizar o comportamento dos Membros (negociação sob a "sombra do futuro" - ou sob a "sombra da sanção"), ou para que entrem em operação, caso necessário, como "último recurso".2

1 Acordo de Marraqueche Estabelecendo a Organização Mundial do Comércio (“Acordo da OMC"), assinado em Genebra em 15 de abril de 1994.

Shoyer (2005); Drezner (2003). 
$\mathrm{O}$ aprimoramento do enforcement no SSC/OMC também encontra eco nas modificações sentidas em tal regime internacional, deixando de ser um regime somente de "integração negativa" - caracterizada por regras de abstenção, de que são exemplo as Cláusulas do Acordo Geral sobre Tarifas Aduaneiras e Comércio de 1947 (“'GATT 1947”) da Nação-Mais-Favorecida (Artigo I, GATT 1947) e do Tratamento Nacional (Artigo III, GATT 1947) - e incorporando regramentos de "integração positiva", como o Acordo sobre Aspectos dos Direitos de Propriedade Intelectual Relacionados ao Comércio (“TRIPS"), o Acordo Geral sobre o Comércio de Serviços (“GATS”), o Acordo sobre a Aplicação de Medidas Sanitárias e Fitossanitárias ("SPS") e o Acordo sobre Barreiras Técnicas ao Comércio ("TBT"), ${ }^{3}$ derivados da Rodada Uruguai. A mudança no perfil do modelo integrativo incorporado no Acordo da $O M C$ não chega a transmudar a natureza das obrigações constantes de tal acordo (embora já haja quem defenda sua natureza erga omnes partes), mas certamente coloca a obrigação de obediência/observância em um patamar bastante elevado.

Nesse sentido, é nítido que os Membros da OMC, ao negociarem o Entendimento sobre Solução de Controvérsias ("ESC") do Acordo da OMC, colocaram a necessidade de compliance em um elevado patamar. São exemplo disso a exclusividade com que os Membros devem se socorrer das regras do ESC ao buscarem a interpretação das obrigações constantes do Acordo da OMC ou o enforcement de tais regras ou das recomendações do OSC, conforme estatuído expressamente no Artigo 23 do ESC, de título auto-explicativo: "Strengthening of the Multilateral System". A necessidade de observância estrita vem sendo cada vez mais realçada pela doutrina e, sobretudo, por manifestações contidas em relatórios de painéis e do Órgão de Apelação, subsequentemente aprovados pelo OSC.

A despeito de todas essas indicações em favor do estrito cumprimento das obrigações constantes do Acordo da OMC, o sistema de enforcement ainda se baseia na bilateralidade. Com efeito, os fundamentos para adoção de contramedidas encontram-se previstos no artigo 22 do ESC, o qual tem origem no Artigo XXIII do GATT 1947. A base da implementação encontra-se no próprio poder dos Membros de fazer com que o outro Membro - via retaliação - concorde em implementar a decisão do OSC. O mecanismo

$3 \quad$ Pauwelyn (2003), p. 71. 
presente no ESC para tanto se centra na reciprocidade (baseado em uma bilateralidade), tal qual delineado no Artigo XXIII do GATT 1947.

Posto isso, a questão é que a bilateralidade da retaliação/contramedida tem sido percebida como insuficiente. A par da discussão acerca do tipo de integração incorporada no Acordo da $O M C$, a bilateralidade das contramedidas no âmbito da OMC parece ser insuficiente em casos envolvendo desequilíbrio de poder.

Com efeito, contramedidas bilaterais, consistentes na suspensão de concessões ou obrigações por parte de países de menor desenvolvimento, dificilmente poderão fazer frente a Membros como Estados Unidos (“EUA') e União Europeia (“UE”). Muitas vezes, estar-se-á diante de situações em que a contramedida mais afetará o Membro demandante do que o Membro demandado. O reconhecimento de tal situação de desequilíbrio se encontra implicitamente estampado no Artigo 22.3 do ESC, que prevê a possibilidade excepcional de aplicação da chamada "retaliação cruzada", ou seja, contramedidas em setores cobertos por outros acordos do Acordo da OMC, diferentes daquele em cujo âmbito o contencioso se desenvolveu. O desequilíbrio de poder, assim, acentua a dificuldade de o próprio Membro demandante arcar com os custos da sanção. A implantação de um mecanismo coletivo de sanção (ou seja, em que diferentes Membros compartilham dos custos da sanção) parece contribuir para sanar essa deficiência do SSC/OMC. ${ }^{4}$

Embora sejam minoria os casos em que o Membro demandado não implementa a decisão do OSC, tem-se que o descumprimento de decisões, especialmente por Membros países desenvolvidos, pode levar a um efeito de redução da legitimidade do sistema de solução de controvérsias, senão da própria instituição. Propostas apresentadas ao OSC há tempos por Membros em desenvolvimento ou de reduzido grau de desenvolvimento acentuaram esse aspecto, ${ }^{5}$ o qual não pode, portanto, ser desprezado.

\footnotetext{
$4 \quad$ Pauwelyn (2003), p. 78.

$5 \quad$ "The question of little or no utilization of the WTO DS by developing and least-developed country Members has been linked to the inadequacies and structural rigidities of the remedies available to poor countries that successfully litigate a dispute before the DS. (...) The lack of an effective enforcement mechanisms and the potential negative impact of retaliatory measures for poor economies is well documented. LDCs are of the view that one solution to this handicap is to adopt a 'principle of collective responsibility' akin to its equivalent under the United States Charter. Under this principle, all WTO Members would collectively have the right and responsibility to enforce the recommendations of the DSB. In the case where a developing or least-developed country Member has been a successful complainant, collective retaliation should be available automatically, as a matter of special and different treatment. In determining whether to authorize collective retaliation, the DSB should not be constrained by quantification
} 
A adoção de contramedidas multilaterais, ou seja, por diferentes Membros contra o Membro demandado, parece ser uma solução possível para o dilema de compliance no âmbito do SSC da OMC. Há estudos demonstrando sua possível eficácia, além de propostas perante o Comitê de Negociações Comerciais da OMC especificando formas de sua implementação, embora ainda não tenha amealhado um nível de apoio suficientemente elevado. ${ }^{6}$

Antes de se propor uma forma detalhada de sua implementação, propomos averiguar se e em quais condições um sistema de retaliação coletiva seria necessário e viável no âmbito do SSC/OMC. Para tanto, utilizamo-nos da teoria de formação de alianças, desenvolvida pela escola realista, desde Hans J. Morgenthau, George Liska, passando por Kenneth Waltz, Stephen Walt e, finalmente, Glenn N. Snyder, com o que esta tese se alinha firmemente na metodologia (neo)realista, tal qual definida no Capítulo VI abaixo.

Nesse sentido, esta tese se desenvolve da seguinte forma: o Capítulo I apresenta uma breve introdução acerca deste trabalho; o Capítulo II expõe o dilema do cumprimento (compliance) das recomendações do OSC, apresentando (i) um breve resumo sobre o procedimento do contencioso perante o $\mathrm{SSC} / \mathrm{OMC}$, (ii) uma introdução aos conceitos de contramedidas (no Projeto CDI e no ESC), e (iii) uma discussão acerca da natureza das obrigações derivadas do Acordo da $O M C$ e da natureza das contramedidas previstas no ESC, valendo-se, para tanto, de análise sobre o posicionamento doutrinário e dos “precedentes" do SSC/OMC a respeito (no caso, exame de cada um dos onze relatórios que analisaram pedidos de aplicação de contramedidas - as chamadas arbitragens do Artigo 22.6 do ESC). O Capítulo III expõe sobre as principais propostas para solução do problema do compliance no SSC/OMC, apresentando-as tipologicamente. Em seguida, o Capítulo IV trata especificamente da retaliação coletiva, conceituando-a e analisando-a com base nos posicionamentos dos diversos autores que a abordaram. O Capítulo V, por sua vez, cuida de apresentar a teoria de formação de alianças, situando-a dentro da discussão sobre o equilíbrio de poder, característica do discurso de Morgenthau e de Waltz, evoluindo

on the basis of the rule on nullification and impairment." Comunicado da Zâmbia de 9 de outubro de 2002 [TN/DS/W/17].

Relatório do Presidente, Embaixador Péter Balás, ao Comitê de Negociações Comerciais (WT/TN/DS/9). 
historicamente no desenvolvimento da teoria, até se focar na literatura mais recente (como Stephen Walt e Glenn N. Snyder), fundado em que prepara as bases para a discussão seguinte. O Capítulo VI aplica a teoria de formação de alianças ao SSC/OMC, buscando caracterizar os elementos que compõem o sistema multilateral de comércio, a saber: Estrutura, Unidades, Relacionamentos e Interação, conforme as concepções da escola neorrealista, identificando-se a seguir as condições que favorecem ou não a formação de alianças no âmbito do SSC/OMC (para tanto, analisaram-se as condições fáticas concernentes a cada uma das onze arbitragens do Artigo 22.6 do ESC, objeto do Capítulo II), com o que se permitiu concluir acerca das situações em que um mecanismo de retaliação coletiva seria desnecessário, facultativo ou obrigatório. O Capítulo VI ainda aplica às situações fáticas previstas nos casos CE - Bananas $I I I^{7}$ e EUA-Jogos e Apostas $^{8}$ a Teoria da Paisagem de Agregação, com o intuito de testar as conclusões anteriormente obtidas. Com base nas conclusões apuradas no Capítulo VI, o Capítulo VII apresenta uma proposta de emenda ao $E S C$, para incorporação de um mecanismo de retaliação coletiva no SSC/OMC. O Capítulo VIII encerra a tese, realçando suas principais conclusões.

7 European Communities - Regime for the Importation, Sale and Distribution of Bananas (Complainants: Ecuador; Guatemala; Honduras; Mexico; United States of America), DS27, recebido em 5 de fevereiro de 1996 (“CE - Bananas III”).

8 United States - Measures Affecting the Cross-Border Supply of Gambling and Betting Services, DS285, recebido em 13 de março de 2003 ("EUA - Jogos e Apostas"). 


\section{O DILEMA DO CUMPRIMENTO DAS RECOMENDAÇÕES DO OSC NO SSC/OMC}

\section{A. Introdução}

Antes de formular uma proposta voltada ao aprimoramento do mecanismo de enforcement da OMC, faz-se necessário expor acerca de suas características atuais. Isso porque só se pode considerar que uma medida aprimora um determinado sistema quando essa medida incorpora os objetivos desse sistema e contribui para promovê-los. Afirmar que a implementação da retaliação coletiva significa um aprimoramento do mecanismo de enforcement da OMC significa, assim, dizer: (i) que o mecanismo que se chama "de enforcement" tem efetivamente essa função, isto é, representa uma maneira de fazer cumprir os acordos da OMC; e (ii) que a adoção da retaliação coletiva no âmbito do SSC será capaz de promover o cumprimento dos acordos com mais eficiência do que o sistema atual é capaz de fazer.

Para responder à primeira pergunta, é preciso adentrar o debate acerca da função da retaliação dentro da OMC. Nesse sentido, será retomado neste capítulo o conhecido debate Jackson-Bello sobre a natureza das obrigações da OMC, levando-se em conta sobretudo a hoje extensa prática dos órgãos de adjudicação da OMC. Um dos pressupostos deste trabalho, afinal, é o de que a retaliação exerce no SSC a função de sanção, e não de mero fator de reequilíbrio de relações contratuais. Como se verá, a prática dos árbitros da $\mathrm{OMC}$, e sobretudo a prática dos Membros, evidencia ser esse o propósito da "suspensão de concessões ou outras obrigações", tal qual prevista pelo ESC.

A resposta da segunda pergunta é o objetivo central deste trabalho. Neste capítulo, limitaremo-nos a demonstrar que, apesar de todo o aprimoramento percebido pelo $\mathrm{SSC} / \mathrm{OMC}$ no sentido de propiciar aos Membros instrumentos de enforcement dos acordos, o mecanismo atual apresenta limitações, as quais não podem ser sanadas dentro da lógica atual de bilateralização da retaliação. 


\section{B. Breve Resumo sobre o Procedimento de um Contencioso perante o SSC/OMC}

A discussão objeto deste trabalho se foca no extremo final de um contencioso perante o SSC/OMC, qual seja, a aplicação de contramedidas (ou retaliação), como forma última de se tentar obter o cumprimento das recomendações do OSC pelo Membro demandado. Antes de se discutir tais questões, apresenta-se a seguir, apenas como referência, uma breve descrição do procedimento do SSC/OMC.

Uma controvérsia da OMC inicia-se oficialmente com um pedido de consultas realizado de um Membro a outro, nos termos do Artigo 4 do ESC. A partir do pedido de consultas formal, o Membro demandado tem de produzir uma resposta em até dez dias, e proceder às consultas em até 30 dias. Caso não o faça, o Membro demandante poderá solicitar o estabelecimento de um painel (Artigo 4.3). De qualquer forma, caso não haja solução por mútuo acordo dentro de 60 dias, a parte reclamante poderá solicitar o estabelecimento de um painel (Artigo 4.7). Já nessa fase, Membros que considerem possuir “interesse comercial substancial" (Artigo 4.11) podem manifestar desejo de integrar as consultas. O Membro demandado tem, nesse momento, a possibilidade de negar que a pretensão de interesse substancial tenha fundamento - embora não possa impedir que o Membro rejeitado formule seu próprio pedido de consultas independente (ibid.).

Caso não haja solução mutuamente satisfatória durante o período de consultas, o Membro que as solicitou poderá requerer o estabelecimento de um painel. Na primeira reunião em que esse item aparecer na agenda, ali colocado pelo Membro demandante, não se aplica o consenso negativo - embora, havendo concordância do Membro demandado, a prática permita ao OSC estabelecer o painel já nessa reunião. Na segunda reunião em que o caso constar da agenda, o painel será estabelecido pelo OSC, a não ser que todos os Membros - incluindo o demandante - decidam o contrário (Artigo 6.1).

A composição dos painéis é feita por acordo entre as partes, podendo o Secretariado da OMC propor nomes às partes (Artigo 8.6). Decorridos 20 dias do estabelecimento do painel, não havendo acordo sobre sua composição, qualquer das partes pode solicitar ao Diretor-Geral da OMC que determine essa composição, nomeando os 
integrantes mais apropriados (Artigo 8.8). O ESC especifica que, quando mais de um Membro solicitar o estabelecimento de um painel para tratar de uma mesma questão, um mesmo painel seja estabelecido para examinar todas as reclamações (Artigo 9.1). Caso isso não ocorra, as mesmas pessoas devem - na medida do possível - integrar os diferentes painéis (Artigo 9.3).

O Artigo 10.2 determina que todo Membro que tenha interesse concreto ("substantial interest") em um assunto submetido a um painel terá oportunidade de ser ouvido e de apresentar comunicações escritas.

A regra geral é que, com o objetivo de tornar o procedimento mais eficaz, o prazo entre o estabelecimento de um painel e a divulgação de seu relatório não ultrapasse seis meses (Artigo 12.8). Caso não seja possível divulgar o relatório dentro desse prazo, o painel deve informar por escrito ao OSC as razões do atraso e realizar uma estimativa do prazo em que essa divulgação ocorrerá (Artigo 12.9). O ESC determina ainda que em nenhum caso poderá o prazo entre o estabelecimento do painel e a divulgação do relatório ultrapassar nove meses (ibid).

Após receber arrazoados das partes, considerar as réplicas destas e ouvir as apresentações orais, o painel distribuirá um esboço de relatório expondo fatos e argumentações, relatório esse que pode ser objeto de comentários das partes (Artigo 15.1). Em seguida, o painel distribuirá às partes um relatório provisório, que inclui tanto os capítulos descritivos quanto as determinações e conclusões do painel (Artigo 15.2). As partes poderão então solicitar por escrito que o painel reveja aspectos específicos do relatório provisório antes de distribuir o relatório definitivo aos Membros (ibid.).

Um relatório emitido por um painel deve ser examinado pelo OSC e, dentro de 60 dias a partir de sua distribuição aos Membros, será adotado salvo consenso em contrário (Artigo 16.4). A adoção não prejudica o direito de Membros expressarem opinião sobre o relatório. O relatório não será adotado nesse momento, entretanto, se uma parte notificar o OSC da sua decisão de apelar do relatório (ibid.).

A contar da notificação por uma parte de que deseja apelar do relatório do Painel, o Órgão de Apelação tem 60 dias para distribuir seu relatório (Artigo 17.5). Caso entenda 
que não será capaz de cumprir esse prazo, esse órgão deverá notificar por escrito o OSC sobre as razões do atraso, e em todos os casos deve apresentar seu relatório em até 90 dias da apelação (ibid.). O relatório do Órgão de Apelação, assim como o relatório do painel conforme modificado pelo Órgão de Apelação, serão então aprovados - salvo consenso em contrário - pelo OSC, novamente sem prejuízo ao direito de Membros de exporem suas opiniões sobre os relatórios (Artigo 17.14).

Em reunião do OSC ocorrida até 30 dias após a adoção do relatório (apelado ou não), um Membro condenado deverá informar ao OSC suas intenções com relação à implementação das decisões e recomendações adotadas (Artigo 21.3). Se não for possível proceder à implementação imediata, o Membro deve também informar um prazo razoável de tempo ("PRT") dentro do qual pretende implementar as recomendações e decisões contidas no relatório (ibid.). Esse prazo pode ser proposto pelo próprio Membro e aceito pelo OSC (Artigo 21.3(a)), mutuamente acordado pelas partes em controvérsia (Artigo 21.3(b)) ou determinado mediante arbitragem compulsória (Artigo 21.3(c)). No último caso, embora o árbitro seja livre para fixar o prazo, deve ter em mente um prazo de 15 meses da adoção do relatório (Artigo 21.3).

O Artigo 21.4 do ESC determina que todo o prazo transcorrido entre o estabelecimento do painel e a determinação do PRT não deve em regra ultrapassar 15 meses, e não pode ultrapassar 18 meses exceto se as partes considerarem as circunstâncias da controvérsia como excepcionais.

Em caso de discordância acerca do status da implementação do relatório, ou seja, se o Membro demandado implementou medidas para assegurar o pleno cumprimento das recomendações do OSC, o Artigo 21.5 do ESC determina novo recurso aos procedimentos de solução de controvérsias, ou seja: novo painel, com nova possibilidade de recurso ao Órgão de Apelação (o chamado painel do Artigo 21.5). Esse painel de implementação deverá distribuir seu relatório em até 90 dias da data em que a questão lhe for submetida, enquanto para o Órgão de Apelação vale o prazo ordinário de 60 ou 90 dias (Artigo 17.5).

O Artigo 22.1 autoriza o Membro demandante, caso vencedor, a aplicar "suspensão de concessões ou outras obrigações" contra o Membro demandado que, condenado, não cumpra após a passagem do PRT as recomendações e decisões contidas no relatório 
adotado pelo OSC. Essa suspensão de concessões ou outras obrigações é chamada de "contramedidas" ou, usualmente, "retaliação". Sua adoção deve ser precedida de negociações entre o Membro condenado e as outras partes, de forma a buscar uma compensação mutuamente aceitável - a qual deve ser compatível com os acordos (ibid.). Nenhuma dessas duas opções, contudo, é preferível à total implementação das recomendações e decisões do relatório aprovado pelo OSC (ibid.).

Caso dentro de 20 dias da expiração do PRT não tenha havido acordo sobre uma compensação satisfatória, as partes que houverem recorrido ao OSC contra o condenado podem solicitar ao OSC autorização para retaliar a parte condenada (Artigo 22.2). Essa retaliação deve obedecer a dois critérios diferentes, um quantitativo e outro qualitativo. Quantitativamente, seu "grau (...) deve ser equivalente ao grau de anulação ou prejuízo" (Artigo 22.4). Qualitativamente, a parte que aplica retaliações deve procurar suspender em primeiro lugar concessões no mesmo acordo violado (Artigo 22.3(a)); caso considere ser “não praticável nem ineficaz" essa suspensão de concessões, a parte deverá ainda procurar suspender concessões ou outras obrigações em "outros setores abarcados pelo mesmo acordo" (Artigo 22.3(b)); apenas no caso de essa possibilidade também ser impraticável ou ineficaz, e se a parte considerar que "as circunstâncias são suficientemente graves", podem ser suspensas concessões ou outras obrigações em acordo diferente do violado.

O Artigo 22.6 autoriza o Membro condenado a impugnar a suspensão proposta, contestando sua adequação tanto no aspecto quantitativo, quanto no qualitativo. Nesse caso, o mesmo Artigo determina que a questão deva ser submetida à arbitragem. Essa arbitragem (a chamada arbitragem do Artigo 22.6) deve ser efetuada pelo painel que inicialmente tratou do assunto, se seus membros estiverem disponíveis, ou por um árbitro designado pelo Diretor-Geral (Artigo 22.6), e deverá ser completada em até 60 dias da expiração do PRT.

Entre os Artigos 21.5 e 22.6 ocorre o que se chamou de o "problema do sequenciamento". O Artigo 22.6 parece ser aplicável logo após o fim do PRT e, visto que a arbitragem que estabelece deve terminar logo após o fim do PRT, pode dar a entender que se ela não ocorrer nesse prazo a parte perde o direito a solicitar retaliações. Entretanto, o Artigo 21.5 parece ser o mais apropriado para determinar a ocorrência de implementação, determinação logicamente necessária para a autorização de retaliações. Essa questão 
permanece em aberto, visto que o Órgão de Apelação recusou-se a decidir acerca do "problema do sequenciamento" - argumentando tratar-se de competência exclusiva dos Membros. ${ }^{9}$ A prática é a adoção de "acordos de sequenciamento" entre as partes, pelas quais o procedimento do Artigo 21.5 pode ser iniciado e finalizado antes que a parte demandante, se vencedora, deva solicitar autorização para retaliações.

Em caso de não-implementação, a retaliação é a "solução última" para problemas dentro do SSC/OMC, caso não ocorra nem implementação nem solução consensual. Entretanto, é uma solução classificada pelo ESC de temporária (Artigo 22.8), e o procedimento não termina necessariamente com a autorização para retaliações. Pode ocorrer de serem autorizadas retaliações e, em seguida, haver controvérsia entre o Membro inicialmente demandado - que acredita ter implementado as recomendações e decisões - e o Membro inicialmente demandante, que discorda. O Órgão de Apelação recentemente decidiu que nada impede o Membro inicialmente demandado de buscar ele uma decisão multilateral de que ocorreu implementação das recomendações e decisões. ${ }^{10}$ Até essa decisão ser adotada, entretanto, permanece a primeira decisão multilateral, que autorizou as retaliações.

De toda forma, a legitimidade para aplicação de contramedidas somente cabe ao Membro demandante, que deu causa à controvérsia, caso prevaleça perante o SSC/OMC. Não há ainda no ESC previsão para que outros Membros - mesmo os que tenham participado como terceiras partes - participem voluntária ou obrigatoriamente da aplicação das contramedidas autorizadas ao Membro demandante. Denota-se, portanto, que a base da implementação encontra-se no próprio poder do Membro demandante de fazer com que o Membro demandado - via retaliação - concorde em implementar a decisão do OSC. O mecanismo presente no ESC para tanto centra-se na reciprocidade (baseado em uma bilateralidade), tal qual delineado originariamente no Artigo XXIII do GATT 1947.

\footnotetext{
9 United States - Import Measures on Certain Products from the European Communities ("EUA - Certos Produtos das $\boldsymbol{C E}^{\prime \prime)}$, relatório do Órgão de Apelação [WT/DS165/AB/R], 11 de dezembro de 2000, 992.

${ }^{10}$ United States - Continued Suspension of Obligations in the EC-Hormones Dispute ("EUA - Suspensão Continuada"), relatório do Órgão de Apelação [WT/DS320/AB/R], § 345 ss.
} 


\section{Contramedidas na OMC: Sanção (Não Reequilíbrio)}

Há uma visão segundo a qual os acordos da OMC teriam uma natureza jurídica diferente de outros acordos de direito internacional. O argumento, exposto pela primeira vez em 1996 por Judith Bello, é de que os acordos "não geram obrigações no sentido tradicional": ${ }^{11}$ os Membros da OMC ter-se-iam concedido mutuamente a opção, normativamente neutra, de descumprir os termos do acordo, bastando compensar esse descumprimento com concessões aos Membros prejudicados ou aceitar que estes descumpram suas próprias promessas em resposta. Nas palavras da autora, "[t] he only true binding WTO obligation is to maintain the balance of concessions negotiated among members". ${ }^{12}$ Por essa lógica, existiria nos acordos até mesmo um certo incentivo ao “descumprimento eficiente" (efficient breach), um descumprimento calculado dos acordos que produza um aumento da produção agregada, com isso trazendo benefícios para a coletividade. ${ }^{13}$ Corresponde a essa visão um mecanismo de retaliação sem caráter de sanção, como mero reequilíbrio do contrato negociado na Rodada Uruguai. ${ }^{14}$

Essa visão foi contestada em 1997 por John Jackson, e desde então essa questão é conhecida como "the Jackson-Bello debate", 15 o qual foi alimentado por vários outros doutrinadores. Essencialmente, examinando detidamente o texto do ESC, Jackson argumenta que as obrigações da OMC são plenamente vinculantes, ao menos no mesmo sentido em que são vinculantes todas as obrigações de direito internacional. ${ }^{16}$ Não é crucial, para a aceitação da proposta aqui apresentada, que a razão neste debate teórico esteja com Jackson; o essencial é o reconhecimento de que o caráter das contramedidas

\footnotetext{
$11 \quad$ Bello (1996), p. 416.

12 Ibid., p. 418.

13 Schwartz and Sykes (2002). O modelo continua a ser utilizado: Collins (2009).

14 A questão é descrita com precisão por Robert Lawrence: "In this construct, the party that runs afoul of an agreement may be likened to a renter who breaks a lease. Such a breach is not an act of negligence nor is it a crime or infraction that should be punished. Contracts are, after all, not social obligations. Breach is a matter between the parties and does not violate commitments to the community (members) as a whole. Once it provides adequate compensation, the promisor in a contract is usually fully relieved of its obligations. To be sure, its reputation and future credibility may suffer as a result of the breach. However, if it decides that it would be better off by breaching the contract, and if the promisee can be left in a position that is no worse than had the contract been fulfilled, the society benefits from allowing such a breach" (Lawrence (2003), p. 15 .

$15 \quad$ Vide, por exemplo, Pauwelyn (2003), p. 27.

16 Jackson (1997), p. 63.
} 
dentro do sistema da OMC é precisamente o de sanção jurídica, não de mero "reequilíbrio contratual".

Nesse sentido, uma observação importante é que o debate Jackson-Bello data de dois anos antes do primeiro relatório arbitral autorizando a aplicação de contramedidas. ${ }^{17}$ Conforme se passará a demonstrar, o desenvolvimento do direito da $\mathrm{OMC}$ e a prática da organização não deixam dúvidas hoje sobre a função das retaliações dentro da estrutura jurídica dos acordos: trata-se de verdadeira sanção privada, ${ }^{18}$ aplicada pelo Membro demandante com o fim de pressionar o demandado a cumprir suas obrigações - e não, sublinhe-se, de um substituto desse cumprimento.

Nessa linha, o Artigo 3.7 do ESC é inequívoco a respeito, estipulando que o “objetivo do mecanismo de solução de controvérsias é garantir uma solução positiva para as controvérsias". A supressão das medidas incompatíveis, "primeiro objetivo do mecanismo de solução de controvérsias", é preferida, mas apenas na "impossibilidade de uma solução mutuamente acordada". Essa linguagem levou alguns autores, na linha de Judith Bello, a concluir que "compliance with the WTO (...) remains elective", ${ }^{19}$ e que "the only sacred WTO imperative is to maintain that [negotiated] balance [of rights and obligations] so as to maintain political support for the WTO Agreement by members". ${ }^{20}$ Alguns autores adeptos da tradição do Law and Economics argumentam que a OMC permite ou deveria permitir a chamada violação eficiente ("efficient breach"), capaz de aumentar o bem-estar geral, ${ }^{21}$ enquanto outros acreditam que a OMC não deve proibir os Membros de realizarem escolhas sociais, como a proibição de venda de alimentos transgênicos ou a defesa de políticas ambientalmente sustentáveis. ${ }^{22}$

Um exame jurídico mais atento dos acordos, contudo, observará que o Artigo 3.7 do $E S C$ estabelece que "[d]everá ser dada preferência à solução mutuamente aceitável para

$17 C E-$ Bananas III, Arbitragem do Artigo 22.6, pedido original dos EUA [WT/DS27/ARB], decisão de 9 de abril de 1999.

18 Para exames de contramedidas no direito internacional e seu caráter de justiça privada, vide Zoller (1984) e Alland (1994).

$19 \quad$ Bello (1996), p. 417.

$20 \quad$ Ibid.

21 Trachtman (2007), p. 130. Collins (2009), entretanto, lembra que "[t]he adaptability of efficient breach to WTO remedies rests upon the often-drawn, and perhaps artificial, comparison between WTO agreements and the law of contract" (p. 230).

22 Para uma discussão, vide Lawrence (2003), pp. 16-18. 
as partes $e$ que esteja em conformidade com os acordos abrangidos" (itálico acrescentado). A conjunção aditiva significa que tanto um quanto outro são requisitos essenciais a essa solução preferível. Essa interpretação se apóia ainda no Artigo 22.1 do ESC, que estabelece que a compensação e a retaliação são "medidas temporárias", explicitando que, das três soluções possíveis para uma controvérsia, "nem a compensação nem a suspensão de concessões ou outras obrigações é preferível à total implementação de uma recomendação" do OSC. Finalmente, o Artigo 26.1(d) autoriza a compensação a fazer parte de "um ajuste mutuamente satisfatório como solução final para a controvérsia", no caso de reclamações de não-violação, "não obstante o disposto no parágrafo 1 do Artigo 22"; contrario sensu, pode-se concluir que a "preferência" estabelecida nesse artigo implica efetivamente que a compensação não caracteriza uma solução final para a controvérsia.

Essa interpretação, de que as retaliações são instrumento de enforcement e não de reequilíbrio, encontra ainda apoio na prática dos Estados, como demonstram Shaffer e Ganin num estudo que engloba as autorizações de retaliação até aquela concedida a Antígua e Barbuda em EUA - Jogos e Apostas (2007). ${ }^{23}$ Os autores observam que, de todos os casos em que foi constatada incompatibilidade com o Acordo da OMC após a expiração do período razoável de tempo, apenas em $28 \%$ houve solicitação de retaliações, e apenas em $8 \%$ houve efetiva imposição. Mesmo EUA e CE, dentre as vezes em que tiveram essa possibilidade, aplicaram poucas vezes a retaliação. Quando o fizeram, houve muito mais ameaça do que aplicação e diversos adiamentos aguardando o processo legislativo do Membro violador. Se os Membros considerassem a retaliação um reequilíbrio vantajoso das relações comerciais, deveriam aplicá-la sempre que tivessem a oportunidade.

Adicionalmente, os Membros procuram fazer a ameaça parecer o mais prejudicial possível para os exportadores do Membro violador. Assim, publicam longas listas com o fim de alarmar diversos setores destes, e buscam sempre atingir aqueles setores politicamente mais fortes no Membro violador. No caso dos EUA, houve a ameaça da retaliação "carrossel” às $\mathrm{CE}$, que afetaria setores de maneira imprevisível. Países em desenvolvimento buscam com frequência a retaliação em propriedade intelectual, com o

$23 \quad$ Shaffer e Ganin (2009), pp. 73-86. 
objetivo explícito de realizar pressão sobre setores como a indústria farmacêutica e de tecnologia dos países desenvolvidos. Nada disso, afirmam Shaffer e Ganin, é compatível com a ideia de que as retaliações serviriam para reequilibrar o acordo ou trariam qualquer vantagem ao Membro retaliante.

Assim, tanto em se partindo da interpretação das obrigações, como faz Jackson, ${ }^{24}$ como da análise da prática, como faz Charnovitz, ${ }^{25}$ pode-se concluir que a "suspensão de concessões ou outras obrigações" prevista pelo ESC exerce a função de sancionar o descumprimento de uma norma vinculante. É aplicada como retaliação, com a finalidade essencial de produzir, pressionando setores politicamente influentes no outro Membro, uma mudança de comportamento no sentido de que este passe a cumprir os acordos. Tendo isso em vista, pode-se concluir que as retaliações têm no sistema da OMC, tanto de jure como de facto, a função de induzir o Membro retaliado ao compliance. Como bem destacou Amaral Jr.: “[O] principal objetivo desse instrumento não é o ressarcimento das perdas e danos, mas a criação de estímulos concretos para a execução das decisões com o aumento da pressão exercida sobre os países desenvolvidos". ${ }^{26}$

Como se vê, o exame textual do ESC traz diversas disposições nesse sentido, o que se reflete inclusive na terminologia corrente, com o uso do termo "contramedidas" para referir a "suspensão de concessões ou outras obrigações". É entretanto na prática da organização e de seus Membros que se observará com mais clareza que a retaliação não é utilizada como forma de "reequilibrar o contrato", 27 e sim com a intenção deliberada de forçar o cumprimento dos acordos. Essa interpretação terá impacto decisivo no desenho das modificações pretendidas no ESC, sobretudo no aprimoramento do instituto "contramedidas".

\footnotetext{
$24 \quad$ Jackson (2004).

25 Charnovitz (2001), pp. 807-808 (argumentando que a função de reequilíbrio, existente no GATT, alterou-se para sanção na OMC).

26 Amaral Jr. (2008), p. 115.

27 Na realidade, a retaliação como estabelecida dentro da OMC nem mesmo tem a possibilidade de reequilibrar o contrato, pois não traz vantagem para o Membro que a aplica. Vide Capítulo II.C.3 abaixo.
} 


\section{Contramedidas no Projeto CDI}

A designação "contramedidas" aparece no Projeto de Artigos sobre a Responsabilidade dos Estados por Fato Internacionalmente Ilícito, elaborado pela Comissão de Direito Internacional da ONU e anexo à Resolução 56/83, de 12 de dezembro de 2001, da Assembleia Geral da ONU (“Projeto CDI”). Essa resolução, herdeira de uma extensa prática de direito internacional, incorpora os parâmetros desenvolvidos pela jurisprudência internacional ao longo do Século XX no que diz respeito às possibilidades e limites da resposta dos Estados a ilegalidades cometidas por outros Estados. ${ }^{28} \mathrm{O}$ capítulo II da terceira parte do Projeto CDI (Artigos 49 a 54) trata das contramedidas em direito internacional geral, de forma que um exame comparativo será importante para se compreender em que medida a "suspensão de concessões ou outras obrigações" pode ser designada propriamente por "contramedidas".

As contramedidas do Projeto CDI são definidas como a inexecução temporária de obrigações internacionais do Estado que as aplica contra o Estado julgado responsável por fato internacionalmente ilícito, ${ }^{29}$ tão-somente com a finalidade de levá-lo a cumprir suas obrigações internacionais. ${ }^{30}$ Em outras palavras, trata-se do direito de um Estado de aplicar, em resposta a uma ilegalidade, medidas que de outra forma seriam ilegais por desrespeitar uma obrigação internacional do Estado aplicador. Observe-se que não há na aplicação das contramedidas uma função de sanção-reparação, nem se vislumbra para aquelas objetivo punitivo: as contramedidas, tendo a função de chamar a atenção da outra parte para a ilegalidade cometida, representam "uma aposta na sabedoria e não na fraqueza da outra parte". 31

Por essa razão, o Projeto CDI determina ainda que as contramedidas devam ser proporcionais ao prejuízo sofrido, tendo em conta a gravidade do fato ilícito e dos direitos

28 Os casos fundamentais são a arbitragem Naulilaa (Portugal v. Alemanha) [1928]; o caso sobre Jurisdição em Matéria de Pesca (Reino Unido v. Islândia) [1974]; a arbitragem sobre o Acordo de Serviço Aéreo (EUA v. França) [1978]; o caso sobre o Pessoal Diplomático e Consular dos Estados Unidos em Teerã (EUA v. Irã) [1980]; e o caso sobre o Projeto Gabcikovo-Nagymaros (Hungria v. Eslovênia) [1997]. A análise pormenorizada de cada caso está fora do escopo do presente trabalho, observando-se que o Projeto CDI foi finalizado após o último deles, levando portanto todos em conta em sua análise.

29 Projeto CDI, Artigo 49(2).

$30 \quad$ Projeto CDI, Artigo 49(1).

31 "[a] wager on the wisdom and not on the weakness of the other party" (arbitragem sobre o Acordo de Serviço Aéreo, ILM, vol. 54, 1978, pp. 339-340, § 91). 
afetados, ${ }^{32}$ não podendo afetar obrigações consideradas fundamentais. ${ }^{33}$ A exigência de proporcionalidade, aqui, tampouco obedece a uma lógica retributiva: visa mais a evitar uma escalada de contramedidas e contra-contramedidas, possibilidade que não pode ser excluída tendo em vista a ausência em direito internacional geral de instituições judiciárias capazes de controlar de maneira imparcial a legalidade ou ilegalidade da medida original.

As contramedidas do Projeto CDI, portanto, não têm por função restabelecer qualquer "equilíbrio de vantagens negociadas", mas chamar a atenção do Estado que se estima violador com mais do que medidas ou declarações exortatórias. Exatamente por esse motivo, devem ser precedidas de demanda ao Estado responsável para que cumpra suas obrigações, assim como de notificação do teor das medidas ao Estado responsável, oferecendo a este a possibilidade de negociação. ${ }^{34}$ Reforça essa função o fato de que as contramedidas não devem persistir até que se atinja uma "equivalência de prejuízos", mas devem cessar assim que o Estado responsável cumprir as obrigações decorrentes do fato internacionalmente ilícito. ${ }^{35}$

\section{Contramedidas no ESC}

Embora o termo "contramedidas" não seja utilizado no $E S C,{ }^{36}$ tornou-se corrente designar assim a "suspensão de concessões ou outras obrigações" prevista pelo acordo. ${ }^{37}$ Nas palavras de Charnovitz, as contramedidas representam um último recurso à disposição dos Membros da OMC em caso de descumprimento persistente dos acordos. ${ }^{38} \mathrm{Um}$ exame das disposições do ESC que dão os contornos desse último recurso permitirá comparar esse mecanismo com as contramedidas em direito internacional geral.

As contramedidas da OMC podem ser caracterizadas como a última etapa do procedimento de solução de controvérsias da organização. Como visto anteriormente, um contencioso perante o $\mathrm{SSC}_{\mathrm{OMC}}{ }^{39}$ se inicia com pedido de consultas, prossegue com a

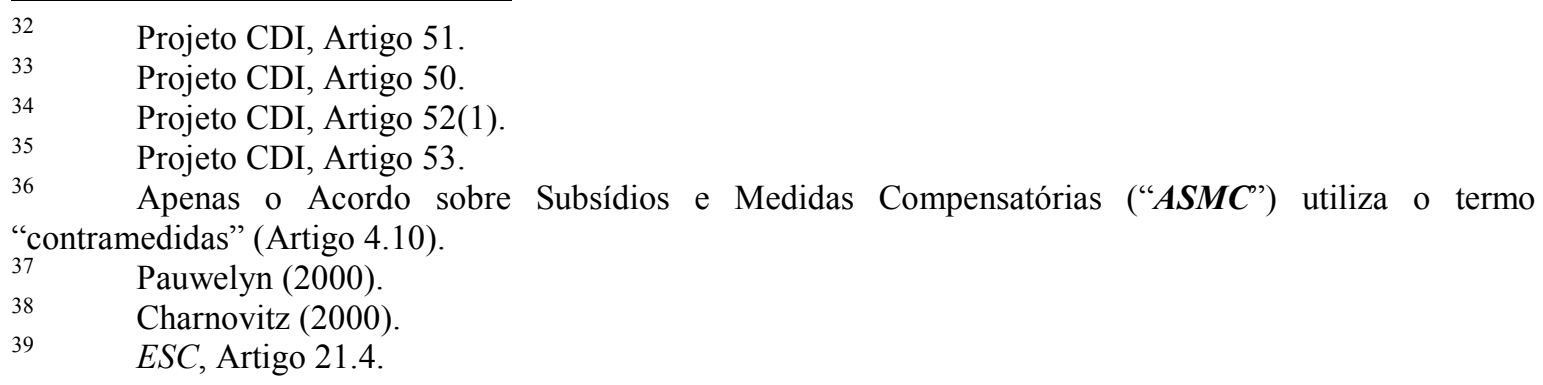


instauração de um painel, sua efetiva instauração pelo SSC/OMC com subsequente processamento até a emissão de relatórios do painel constituído e/ou do Órgão de Apelação (posteriormente adotados pelo OSC), indicando a incompatibilidade da medida objeto do contencioso com o Acordo da OMC (ou algum dos acordos integrantes do Acordo da $O M C)$.

Em caso de ilegalidade da medida ou política examinada, o Membro demandado deve cumprir as decisões e recomendações do OSC em um "período razoável de tempo", o qual, em circunstâncias normais, não passará de quinze meses. ${ }^{40}$ Após a passagem desse período, o Membro inicialmente vencedor tem o direito de solicitar um novo relatório, de um "painel de implementação" (ou "painel do Artigo 21.5"), no qual painel e Órgão de Apelação poderão examinar o cumprimento das decisões e/ou sugestões/recomendações emitidas no primeiro relatório. ${ }^{41} \mathrm{Se}$ esse novo relatório indicar que se mantém o descumprimento, ou se o Membro demandado não adotar nenhuma medida para implementar o relatório inicial, o Membro demandante poderá solicitar autorização ao OSC para suspender, em relação ao Membro demandado, ${ }^{42}$ concessões ou outras obrigações assumidas no quadro da OMC.

Para tanto, o OSC baseará sua decisão de autorizar a aplicação de contramedidas nos termos do Artigo XXIII do GATT 1994 e nos do Artigo 22 do ESC. Cumpre mencionar que o Artigo XXIII do GATT 1994 nada mais é do que a previsão originalmente instituída no GATT 1947, que permitia às PARTES CONTRATANTES do GATT 1947 (as Partes Contratantes quando tomavam uma deliberação - Artigo II.6(a)) autorizarem uma parte contratante a "suspender concessões ou obrigações" devidas a outra parte contratante. Como a reciprocidade estava no âmago do GATT 1947, natural que a sanção jurídica (a contramedida) contivesse um caráter bilateral, o qual não sofreu modificações desde então, a despeito das diversas e profundas mutações ocorridas no regime de comércio internacional, de ordem institucional (com sua plena institucionalização), de matéria de fundo (com a incorporação de novas áreas-tema, além do aprofundamento dos temas já incorporados), no número de participantes (saltando de 24 a mais de 150) e da natureza do

$40 \quad$ ESC, Artigo 21.3(c).

$41 \quad$ ESC, Artigo 21.5.

$42 \quad$ ESC, Artigo 22.2. 
tipo de integração visada (que passou de uma integração negativa para uma integração positiva).

A despeito desses pontos, interessa observar que as características dessa suspensão de concessões ou de outras obrigações, prevista no GATT 1947 e no ESC, são em muito semelhantes às das contramedidas desenvolvidas na prática e na "jurisprudência" de direito internacional geral.

O Artigo 22.1 determina que as contramedidas: (i) devem ser temporárias; e (ii) não são preferíveis à total implementação de uma recomendação do OSC. Uma leitura apressada dessas características pode levar à conclusão de que há mera "preferência" por uma das alternativas (compliance) em relação à outra (noncompliance acompanhado de retaliação). Essa leitura, entretanto, ignora em primeiro lugar o próprio texto do $E S C$, que deixa claro o caráter temporário que deve ter a segunda situação; ignora, em segundo lugar, que a redação de acordos internacionais, e em especial das cláusulas mais intrusivas nestes, comumente emprega palavras menos assertivas do que seria encontrado em dispositivo semelhante em direito interno. ${ }^{43}$ Como se verá mais adiante, é o uso que se faz desse texto que permite concluir definitivamente sobre a questão. No momento, interessa observar que essas duas características das contramedidas da $\mathrm{OMC}$, a temporariedade e o caráter de não-substitutas do cumprimento da obrigação primária, aproximam as contramedidas da OMC das contramedidas de direito internacional geral descritas no Projeto CDI - as quais devem também ser temporárias ${ }^{44}$ e cessar com o cumprimento da

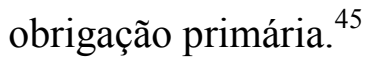

O Artigo 22.3 fornece, tanto ao Membro retaliante, quanto aos possíveis árbitros da retaliação, os critérios para determinar quais obrigações podem ser descumpridas. Apenas obrigações da própria OMC podem ser afetadas, excluindo-se de plano as obrigações de direitos humanos e de caráter humanitário, as da Carta das Nações Unidas e as derivadas de jus cogens. ${ }^{46}$

43 Vide, por exemplo, os Artigos 24 e 25 da Carta das Nações Unidas, que estabelecem para o Conselho de Segurança os direitos de (i) decidir em nome dos Membros; e (ii) criar para estes, sem consentimento, obrigações internacionais.

$44 \quad$ Projeto CDI, Artigo 49(2).

$45 \quad$ Projeto CDI, Artigo 53.

46 Obrigações cuja suspensão é proibida para contramedidas pelo Artigo 50(1) do Projeto CDI. 
Dispositivos semelhantes à proporcionalidade exigida pelo Artigo 51 do Projeto CDI podem ser encontrados no ESC em duas fórmulas. A primeira é a do Artigo 22.4, que prevê que o nível de suspensão de concessões ou outras obrigações autorizado pelo OSC deve ser equivalente ao grau de anulação ou prejuízo sofridos pelo Membro demandante. Trata-se de uma limitação quantitativa à aplicação das contramedidas da OMC. A ela se alia uma limitação qualitativa, a qual determina que as obrigações ou concessões suspensas estejam em regra no mesmo acordo que aquele inicialmente violado, ${ }^{47}$ e no mesmo setor econômico da violação. ${ }^{48}$

A limitação qualitativa, entretanto, aplica-se apenas se a suspensão de concessões ou obrigações no mesmo acordo e setor puder ser considerada não praticável ou ineficaz. ${ }^{49}$ Caso essa aplicação seja não praticável ou ineficaz, o Membro retaliante será autorizado a suspender obrigações em outros setores do mesmo acordo (a retaliação cruzada).

É apenas no caso de subsistir a impraticabilidade ou ineficácia, e em circunstâncias "suficientemente graves", 50 que podem ser atingidos pela retaliação acordos diferentes do inicialmente violado. Em todo caso, o Membro retaliante que deseje afastar a limitação qualitativa deve fundamentar o pedido de retaliação cruzada. ${ }^{51}$ Dessa análise, observa-se que há dois imperativos diferentes a balizar a aplicação das contramedidas: de um lado, a exigência de respeito à proporcionalidade - na forma de equivalência entre prejuízos de prejudicado e retaliado; de outro, a necessidade de eficácia das medidas.

A alínea (d) do Artigo 22.3 especifica o que deve ser levado em consideração na aplicação dos princípios listados nas alíneas anteriores:

“(i) o comércio no setor ou regido pelo acordo em que o grupo especial

$47 \quad$ O Artigo 22.3(g) dispõe: “para efeito do presente parágrafo, entende-se por 'acordo': (i) no que se refere a bens, os acordos enumerados no Anexo 1A do Acordo Constitutivo da OMC, tomados em conjunto, bem como os Acordos Comerciais Plurilaterais na medida em que as partes em controvérsia sejam partes nesses acordos; (ii) no que concerne a serviços, o GATS; (iii) no que concerne a direitos de propriedade intelectual, o Acordo sobre TRIPS."

$48 \quad$ O Artigo 22.3(f) dispõe: “para efeito do presente parágrafo, entende-se por 'setor': (i) no que se refere a bens, todos os bens; (ii) no que se refere a serviços, um setor principal dentre os que figuram na versão atual da 'Lista de Classificação Setorial dos Serviços' que identifica tais setores 14; (iii) no que concerne a direitos de propriedade intelectual relacionados com o comércio, quaisquer das categorias de direito de propriedade intelectual compreendidas nas Secções 1, 2, 3, 4, 5, 6 ou 7 da Parte II, ou as obrigações da Parte III ou da Parte IV do Acordo sobre TRIPS".

49 ESC, Artigo 22.3(b).

$50 \quad E S C$, Artigo 22.3(c).

$51 \quad E S C$, Artigo 22.3(e). 
ou Órgão de Apelação tenha constatado uma violação ou outra anulação ou prejuízo, e a importância que tal comércio tenha para a parte;

(ii) os elementos econômicos mais gerais relacionados com a anulação ou prejuízo e as consequências econômicas mais gerais da suspensão de concessões ou outras obrigações."

Esses dispositivos balizam a definição do nível e tipo de retaliações, procurando garantir não se tornem desproporcionais, tendo, de um lado, níveis equivalentes aos de prejuízo e sendo razoavelmente previsíveis em forma, e, de outro, se mantendo eficazes em circunstâncias nas quais as limitações de forma implicariam impraticabilidade ou ineficácia das contramedidas.

São as características listadas acima que permitem à doutrina dizer que se incorporou à $\mathrm{OMC}$, de maneira regulamentada, aquilo que a Comissão de Direito Internacional chamou “contramedidas' em seu Projeto de Artigos. Trata-se de conferir ao prejudicado por uma violação o direito de faltar com algumas de suas obrigações internacionais, respeitado o princípio da proporcionalidade, com o fim de levar ao conhecimento do Estado descumpridor, com mais do que medidas ou declarações exortatórias, a insatisfação com a violação. Em ambos os casos, permite-se o que seria de outra forma uma ilegalidade, com o fito de levar a contraparte inadimplente a cumprir com suas obrigações. ${ }^{52}$

Trata-se, enfim, do mecanismo de justiça privada que, na ausência de aparato estatal, faz as vezes de sanção. ${ }^{53}$ Se partirmos, à maneira kelseniana, da identificação na norma pela sanção, devemos concluir que o cumprimento das obrigações da OMC não é uma opção dos Membros, mas uma exigência normativa, ao menos da mesma forma que o cumprimento de qualquer obrigação internacional. ${ }^{54}$ No plano teórico, portanto, deve-se

$52 \quad \mathrm{O}$ fato de os acordos da OMC não preverem em regra a obrigação de reparar o dano passado não prejudica a analogia. Isso porque é a mesma a obrigação do aplicador: cessar as contramedidas em face do cumprimento pela parte retaliada das suas obrigações. No âmbito da $\mathrm{OMC}$, essa obrigação está contida no Artigo 22.8 do ESC. Foi reafirmada pelo Órgão de Apelação em EUA - Suspensão Continuada, relatório do Órgão de Apelação [WT/DS320/AB/R], adotado em 14 de novembro de 2008, § 355.

53 Alland (1994); Zoller (1984).

$54 \quad \mathrm{Na}$ realidade, tendo em vista a existência de controle quase-jurisdicional de seu conteúdo e o enquadramento jurídico das contramedidas, pode-se inclusive dizer que as normas da OMC têm mais solidez do que a maioria das normas de direito internacional, submetidas que estão estas em regra não só à autotutela mas ao autojulgamento. 
concluir que as normas da OMC são normas e devem ser respeitadas; ou, como afirmara Jackson antes mesmo da finalização do Projeto CDI, "[c] ertainly they are binding in the traditional international law sense". 55

\section{Contramedidas Aplicadas: Reequilíbrio ou Punição?}

Ainda que teoricamente se possa concluir que a obrigação de respeitar as normas da OMC é uma obrigação jurídica em sentido forte, isto é, não é permutável por uma compensação financeira, não se pode negar que há um importante elemento contratual na determinação das obrigações da OMC. Com efeito, a própria possibilidade de retaliação evidencia que não se pode equiparar as obrigações da $\mathrm{OMC}$ às obrigações listadas no Artigo 50(1) do Projeto CDI, consideradas obrigações de natureza coletiva ou erga omnes ${ }^{56}$ estas são as obrigações de não usar a força, de respeito aos direitos humanos e ao direito humanitário, bem como as outras obrigações de normas peremptórias de direito internacional (jus cogens).

É certo que o ESC obriga a que as soluções bilaterais sejam compatíveis com os acordos. ${ }^{57}$ Por outro lado, a possibilidade de "solução mutuamente satisfatória" admitida em diversas instâncias pelo ESC não permite dizer que as obrigações da OMC sejam erga omnes partes. O texto do Acordo da OMC (incluindo, obviamente, o ESC) simplesmente não permite tal leitura, já que originariamente baseado na reciprocidade entre os Membros. Ademais, é possível que uma medida ou política julgada incompatível com os acordos seja tolerada no sistema por longos períodos de tempo, fundada em acertos bilaterais entre o Membro autor da medida e os Membros que teriam interesse em vê-la repelida. Isso reforça a leitura de que as obrigações presentes no Acordo da OMC sejam de natureza bilateral, embora não se deva excluir ou ignorar o evidente processo de multilateralização de tais obrigações, rumo a obrigações erga omnes partes.

Pode-se mesmo aceitar que, durante as negociações da Rodada Uruguai, nem todos os Membros da OMC tivessem consciência da legalização extrema que o novo procedimento engendrava. Conforme atesta um autor, "[m]any governments saw these

Jackson (1997), p. 63 (grifo no original).

Pauwelyn (2003b), pp. 907-952.

ESC, Artigos 3.5 e 22.1 
agreements not as a binding legal regime but as a diplomatic-political framework which could provide a 'basis for negotiation between States for the purpose of attaining a balance between benefits and obligations", 58 Entretanto, era também previsível que a transferência de poder jurídico aos órgãos jurisdicionais fosse retirar dos Membros o controle sobre os resultados. Ou, como apontam Esserman e Howse, "once created, an effective international judicial system based on compulsory jurisdiction is likely to be used extensively and intensively". ${ }^{59}$ É possível portanto dizer que os negociadores da Rodada Uruguai foram bem-sucedidos em criar um sistema altamente jurisdicionalizado. ${ }^{60}$ Nesse sistema, o controle quase-jurisdicional da legalidade das políticas adotadas pelos Membros distancia as obrigações do tipo-ideal dos acordos renegociáveis, e aproxima-as de obrigações multilaterais - já que qualquer Membro, mesmo que não tenha participado da negociação inicial para determinado setor, pode questionar a legalidade de uma política naquele setor.

A resposta definitiva para a questão do caráter renegociável ou não dos acordos da OMC está ligada à própria forma como as contramedidas são aplicadas atualmente: vale dizer, na forma como as medidas são encaradas tanto pelo árbitros como pelos Membros da OMC. Passar-se-á, então, a um estudo empírico da aplicação desse mecanismos: caso se verifique que a visão predominante sobre elas é que se trata de uma oportunidade para o Membro aplicador de "reequilibrar o contrato", ganhando com isso oportunidades comerciais que de outra forma não teria, deve-se concluir que as retaliações obedecem a essa lógica de reequilíbrio. Caso se verifique o contrário, isto é, que os Membros que aplicam contramedidas o fazem com a finalidade de produzir o maior incentivo possível ao fim da ilegalidade original, pode-se inferir disso que a função exercida pelo mecanismo é a mesma das contramedidas do Projeto CDI: induzir ao cumprimento das normas, exercendo sobre setores politicamente influentes a maior pressão possível dentro das circunstâncias fáticas e jurídicas do caso.

Antes de passar a esse exame, cabe uma observação: compreende-se que, para alguns economistas liberais, não seja admissível a ideia de benefícios trazidos pelo aumento tarifário - a forma mais comum de aplicação de contramedidas dentro da OMC.

$58 \quad$ Reich (1997), p. 776.

$59 \quad$ Esserman and Howse (2003), p. 140.

60 Stoler (2004). 
Não poucos autores liberais defendem que a imposição e a majoração de tarifas trazem invariavelmente prejuízos, penalizando consumidores internos e reduzindo o bem-estar agregado. Outros argumentam que, a partir do momento em que foi determinada uma tarifa ótima, qualquer aumento tarifário com impacto real desviará o comércio em direção a produtores menos eficientes, novamente em detrimento do consumidor local e da riqueza global.

Não se crê necessário, para as conclusões deste trabalho, posicionamento nesse debate. Embora se reconheça a importância central da análise econômica para determinação pelos atores das suas preferências, bem como para a elaboração de regras e mecanismos que promovam a eficiência econômica, consideraremos neste ponto o comportamento habitual desses atores como um dado. Sabe-se que as negociações comerciais internacionais têm por base a permuta entre os atores de vantagens tarifárias e benefícios regulatórios, e que esses atores em regra condicionam a redução da proteção de seu mercado interno a contrapartidas econômicas de outros atores. Pode-se explicar esse comportamento, em teoria dos jogos, com a liberalização unilateral potencialmente produzindo para a parte que abre seu mercado a "recompensa do trouxa" (sucker's payment). A questão dos incentivos e penalizações ligadas à aplicação das retaliações será examinada em detalhes mais adiante. Pelo momento, partir-se-á da observação de que nas rodadas de liberalização a redução tarifária é tratada como uma concessão, à qual deve corresponder uma vantagem - tarifária ou não - para o Membro que reduz suas tarifas. Por isso, não se pode excluir que a possibilidade de aumentar tarifas seja vista pelos Membros como um benefício - uma maneira de proteger temporariamente setores da sua economia, ou uma oportunidade para negociar com terceiros (a quem o comércio vá ser previsivelmente desviado) alguma concessão em outra área. É o exame da prática das retaliações que permitirá afirmar se esse é o caso.

\section{Relatórios sobre a Natureza das Contramedidas: Arbitragens do Artigo 22.6}

Até o momento, desde a implementação dos resultados da Rodada Uruguai, onze (11) foram os contenciosos em que houve solicitação de aplicação de contramedidas, sempre seguidas de recurso pelo demandado ao Artigo 22.6. Adicionalmente, em um caso as partes recorreram à arbitragem do Artigo 25 para determinar o nível de anulação ou 
prejuízo. ${ }^{61} \mathrm{O}$ exame dessas controvérsias permitirá compreender, em primeiro lugar, o sentido dado às retaliações pelos árbitros e pelas partes, e, em segundo lugar, a problemática da aplicação concreta das contramedidas. A descrição dos casos ajudará, posteriormente, a aplicar a teoria de formação de alianças sobre o SSC/OMC (Capítulo VI abaixo).

\section{1. $C E$ - Bananas $I I$, pedido original dos $\mathbf{E U A}^{62}$}

A primeira arbitragem do Artigo 22.6 ocorreu no caso CE - Bananas III, a pedido dos EUA. Para determinarem o montante da retaliação autorizada, os árbitros concentraram-se no significado da palavra "equivalência" no Artigo 22.7 do ESC, concluindo que ela conotava uma correspondência, identidade ou equilíbrio entre dois níveis, o de concessões a serem suspensas e o de anulação ou prejuízo. ${ }^{63}$ Foi no exame dos parâmetros de cálculo desses níveis que os árbitros expressaram seu juízo sobre a função da retaliação:

"We agree with the United States that this temporary nature indicates that it is the purpose of countermeasures to induce compliance. But this purpose does not mean that the DSB should grant authorization to suspend concessions beyond what is equivalent to the level of nullification or impairment. In our view, there is nothing in Article 22.1 of the DSU, let alone in paragraphs 4 and 7 of Article 22, that could be read as a justification for counter-measures of a punitive nature." 64

A questão central para essa decisão foi a inexistência, para os EUA, de perda nas suas exportações de bananas. A perda sofrida pelos EUA era indireta, ocorrida em função de ser norte-americano o capital da empresa que realizava as exportações de países latinoamericanos para as CE, e também, alegavam os EUA, das perdas em vendas de fertilizantes, pesticidas e maquinaria para os países latino-americanos. Para calcular os prejuízos, os árbitros inicialmente postularam a inexistência de um direito de retaliar derivado da mera ilegalidade da conduta de outro Membro: "a Member's legal interest in compliance by another Member does not, in our view, automatically imply that it is

\footnotetext{
$61 \quad$ United States - Section 110(5) of the US Copyright Act (“EUA - Direitos Autorais").

$62 C E-$ Bananas III, Arbitragem do Artigo 22.6, pedido original dos EUA [WT/DS27/ARB], decisão de 9 de abril de 1999 (CE-Bananas III (22.6: EUA)).

$63 \quad C E-$ Bananas III (22.6:EUA), $\$ 4.1$.

$64 C E-$ Bananas III (22.6:EUA), § 6.3 (ênfase no original).
} 
entitled to obtain authorization to suspend concessions under Article 22 of the DSU, ${ }^{65}$ Admitir essa possibilidade, bem como a autorização para aplicação de contramedidas em função de perdas indiretas (em fertilizantes, pesticidas e máquinas) poderia levar a uma dupla contagem de prejuízos e ser incompatível com a exigência de equivalência do Artigo 22.7 do ESC. Nesse raciocínio, os árbitros expressamente compararam a exigência de equivalência do ESC ao princípio de direito internacional geral de proporcionalidade das contramedidas, conforme expresso no esboço do Projeto CDI. ${ }^{66} \mathrm{O}$ cálculo final, fundado num counterfactual acerca das perdas presumidas para os serviços norte-americanos de exportação de bananas para as $\mathrm{CE}$, levou à autorização para aplicação de retaliação em bens no valor máximo de 191,4 milhões de dólares anuais - contra uma solicitação inicial de um único montante de 520 milhões de dólares.

É interessante observar que o cálculo foi feito a partir do final do prazo razoável de tempo para implementação, ${ }^{67}$ do que se extrai que a incompatibilidade, ainda que declarada, só deve contar para efeitos de cálculo das contramedidas a partir do momento em que termina o prazo estabelecido multilateralmente para o compliance. Para esta decisão, o argumento dos árbitros foi o de que a obrigação das CE não deve ser retroativa e, portanto, os "remédios" só devem atingir o período em que a obrigação se torna exigível - i.e., após o fím do período razoável de tempo. ${ }^{68}$ Esta característica da retaliação, esclarecida em arbitragens posteriores, contribui para caracterizar as contramedidas não como mecanismos retributivos ou compensatórios, mas como mecanismos de exigência do cumprimento de uma obrigação.

A retaliação cruzada foi também tratada no caso, já que as CE argumentavam que o pedido dos EUA de retaliação em bens não correspondia ao prejuízo daquele país, sofrido essencialmente no setor de serviços de distribuição, e que o demandante deveria ter seguido os procedimentos do Artigo 22.3(c). ${ }^{69}$ Os árbitros preferiram uma interpretação mais ampla. Visto que o regime de importação das CE violara e continuava a violar tanto o

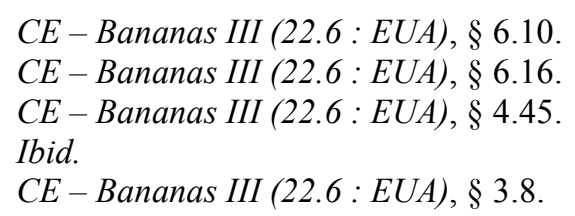


GATT 1994 quanto o GATS, cabia ao demandante decidir em que setor e acordo, dentre os violados, desejava retaliar, até atingir o nível de equivalência. ${ }^{70}$

Após a autorização para aplicação de contramedidas, este contencioso teve uma série de desdobramentos, que culminaram na celebração, em 11 e 30 de abril de 2001, respectivamente, de um acordo entre $\mathrm{CE}$ e EUA e outro entre CE e Equador ("Understanding on Bananas between the EC and the US" $\mathrm{e}$ "Understanding on Bananas between the EC and Ecuador").

A implementação de tais acordos, dependente de um waiver pela Conferência Ministerial da OMC, todavia, foi posteriormente objeto de questionamentos pelo Equador, e pelos EUA, que submeteram a questão a uma arbitragem do Artigo 21.5, para analisar a conformidade das medidas de implementação com os Acordos da OMC. A arbitragem do Artigo 21.5 requerida em 23 de fevereiro de 2007, pelo Equador foi precedida por consultas, às quais se juntaram diversos Membros. ${ }^{71}$ Em 29 de junho de 2007, foi a vez dos EUA requererem a instauração de uma arbitragem do Artigo 21.5.

Com a instauração das arbitragens, decisões finais em ambas arbitragens foram expedidas pelo painel original, posteriormente adotadas pelo OSC. Como conclusão final ficou a de que a medida de implementação da CE para adequação do regime de importação de bananas não era compatível com o Artigo XIII:1 e 2 do GATT 1994, por impor um sistema preferencial de quotas a países ACP (Ásia-Caribe-Pacífico). ${ }^{72} \mathrm{O}$ assunto acabou

$70 \quad$ CE-Bananas III (22.6: EUA), § 3.10 .

71 "On 16 November 2006, Ecuador requested consultations under Article 21.5 of the DSU and Article XXIII of the GATT 1994. On 28 November 2006, Ecuador submitted a revised request for consultations under Article 21.5 of the DSU and Article XXII of the GATT 1994. On 29 November 2006, Colombia requested to join the consultations. On 30 November 2006, Belize, Côte d'Ivoire, Dominica, the Dominican Republic, Saint Lucia, St. Vincent and the Grenadines, and Suriname requested to join the consultations. On 4 December 2006, Cameroon requested to join the consultations. On 6 December 2006, Jamaica requested to join the consultations. On 11 December 2006, Panama and the United States requested to join the consultations. Subsequently, the European Communities informed the DSB that they had accepted the requests of Belize, Cameroon, Colombia, Côte d'Ivoire, Dominica, the Dominican Republic, Jamaica, Panama, Saint Lucia, St. Vincent and the Grenadines, Suriname and the United States to join the consultations. On 23 February 2007, Ecuador requested the establishment of an Article 21.5 panel. At its meeting on 20 February 2007, the DSB deferred the establishment of an Article 21.5 panel. At its meeting on 20 March 2007, the DSB agreed to refer to the original Panel, if possible, the question of whether the new EC banana regime was in conformity with the DSB's recommendations and rulings." (http://www.wto.org/english/tratop_e/dispu_e/cases_e/ds27_e.htm, consultado em 22 de janeiro de 2011). 72 CE - Bananas III, Segundo Recurso à Arbitragem do Artigo 21.5 pelo Equador [WT/DS27/AB/RW2/ECU], decisão de 14 de novembro de 2008 (CE-Bananas III (21.5 : Equador-2)).

$73 C E-$ Bananas III, Arbitragem do Artigo 21.5, pedido de EUA [WT/DS27/AB/RW/USA], decisão de 14 de novembro de 2008 (CE-Bananas III (21.5: EUA)). 
não sendo referido a uma arbitragem do Artigo 22.6, com base na qual o Equador ${ }^{74}$ teria $^{2}$ podido requerer a suspensão de concessões ou outras obrigações em relação às CE.

Em 15 de dezembro de 2009, um acordo ("Geneva Agreement on Trade in Bananas"), 75 classificado como "solução mutuamente acordada", foi anunciado, colocando fim oficialmente a essa disputa (parágrafo 5), tendo como partes, de um lado, a União Europeia, e, do outro, Brasil, Colômbia, Costa Rica, Equador, Guatemala, Honduras, México, Nicarágua, Panamá, Peru e Venezuela.

\section{CE - Hormônios, pedidos originais de EUA e Canadá ${ }^{76}$}

Nesta arbitragem, EUA e Canadá solicitaram autorização para aplicação de contramedidas com base em valores anuais, em consonância com a decisão proferida na arbitragem anterior. Adicionalmente, nenhum dos dois países submeteu uma lista final de produtos. $^{77}$ Além dos valores, portanto, cabia aos árbitros determinar se as retaliações podiam ser autorizadas sem uma lista fixa, dando margem à "retaliação carrossel”, na qual o Membro retaliante altera constantemente a lista de produtos objeto da retaliação, tornando os impactos imprevisíveis para cada setor econômico do Membro retaliado.

Em resposta a essa questão, o raciocínio dos árbitros foi o de que não cabe à arbitragem determinar como devem ser aplicadas as retaliações autorizadas, ou seja, em que produtos, sob qual forma (ad valorem ou não), em que porcentagem adicional. "All of these are qualitative aspects of the proposed suspension touching upon the 'nature' of the concessions to be withdrawn. They fall outside the arbitrators' jurisdiction" ${ }^{78} \mathrm{Na}$ visão dos árbitros, os Membros devem identificar os produtos que podem estar sujeitos a contramedidas de forma a permitir a atribuição de valor anual ao comércio de cada produto quando submetidos à tarifa adicional proposta. Isso feito, entretanto, o Membro retaliante é

74 Provavelmente, os EUA não poderiam vir a requerer suspensão de concessões ou obrigações, pois a medida questionada pelos EUA foi revogada pelas CE ainda no curso desta arbitragem. CE - Bananas III (21.5: EUA), p. USA-162.

75 "Geneva Agreement on Trade in Bananas", comunicado de Brasil, Colômbia, Costa Rica, Equador, União Europeia, Guatemala, Honduras, México, Nicarágua, Panamá, Peru e República Bolivariana da Venezuela [WT/L/784], 15 de dezembro de 2009.

76 European Communities - Measures Concerning Meat and Meat Products (Hormones) ("CE Hormônios"), Arbitragem do Artigo 22.6, pedidos originais de EUA [WT/DS26/ARB] e Canadá [WT/DS48/ARB], decisão de 12 de julho de 1999 (CE - Hormônios (22.6)).

$77 \quad C E-H o r m o ̂ n i o s ~(22.6), \S \S 13$ (EUA)/13 (Canadá).

78 CE - Hormônios (22.6), §§ 19/19, ênfase no original. 
livre para escolher, dentro da lista final, produtos cujo valor anual de comércio, somado, seja inferior ou equivalente ao prejuízo ao comércio determinado em arbitragem. ${ }^{79}$

Novamente, os árbitros consideraram que o nível do prejuízo, determinado para fins de cálculo das contramedidas autorizadas, deveria ser calculado apenas a partir do final do PRT. O raciocínio baseou-se na preferência estabelecida no ESC pela implementação completa dos relatórios, mas a lógica subjacente permaneceu obscura: "To allow the effect of suspension of concessions to exceed that of bringing the measure into conformity with WTO rules would not be justifiable in view of DSU objectives". ${ }^{80}$ Nada impediria que o ESC, com o fito de dar maior peso à preferência que expressa pela implementação, autorizasse contramedidas equivalentes ao prejuízo sofrido desde o relatório final do OSC ou desde o pedido de consultas, por exemplo. Mas os árbitros calcularam o nível de anulação ou prejuízo baseados na seguinte pergunta: quais seriam as perspectivas de exportações anuais de carne tratada com hormônio dos EUA/do Canadá para as CE se a proibição tivesse sido removida em 13 de maio de 1999 - fim do PRT? ${ }^{81}$

A decisão final dos árbitros foi de autorizar contramedidas dos EUA no valor de 116,8 milhões de dólares ao ano (contra 202 milhões anuais solicitados) e do Canadá no valor de 11,3 milhões de dólares ao ano (contra 75 milhões anuais solicitados). ${ }^{82}$ As contramedidas foram aplicadas por tanto os EUA, quanto o Canadá, permanecendo em vigor até esta data.

Posteriormente, o caso se desenvolveu no âmbito de outros dois painéis, agora requeridos pela $\mathrm{CE}$ contra a contínua aplicação de contramedidas por EUA e Canadá. A $\mathrm{CE}$ alegou que, tendo revogado as medidas objeto da disputa anterior, as contramedidas somente poderiam ser aplicadas mediante nova autorização do OSC, o que implicaria violação aos Artigos 3.7, 21.5, 22, 23.1, 23.2 do ESC, especialmente. Afinal, em 16 de

\footnotetext{
79 CE - Hormônios (22.6), $\S \S 21 / 21$. Na arbitragem envolvendo os EUA, as CE solicitaram expressamente aos árbitros que declarassem a ilegalidade da "retaliação carrossel" - aquela na qual a lista de produtos alvo de majoração tarifária se altera constantemente. Os árbitros preferiram não se posicionar, invocando uma declaração dos EUA de que não tinham intenção de alterar a lista de produtos alvo de retaliação. Lembraram apenas que a lista de produtos deve ser elaborada pelos EUA, sendo objeto da arbitragem apenas a decisão sobre o valor de anulação e prejuízo ( $C E$ - Hormônios (22.6), pedido original dos EUA, $\S \S 22-23)$.

$80 \quad$ CE - Hormônios (22.6), $\S \S 39 / 38$.

81 CE-Hormônios (22.6), $\$ \S 38 / 37$.

82 CE - Hormônios (22.6), $\S \S 83 / 72$.
} 
outubro de 2008, o Órgão de Apelação emitiu relatório pelo qual manifestou entendimento de que a declaração das $\mathrm{CE}$ de que havia implementado o relatório não era suficiente para obrigar os EUA e o Canadá a suspenderem a retaliação. Para resolver o impasse, o Órgão de Apelação recomendou às partes que recorressem novamente ao Artigo 21.5, no âmbito da controvérsia original, ${ }^{83}$ o que foi feito pelas CE em 22 de dezembro de $2008 .{ }^{84}$

\section{3. $C E$ - Bananas III, pedido original do Equador ${ }^{85}$}

Esse caso trouxe como grande novidade a invocação explícita pelo Equador das alíneas (b) e (c) do Artigo 22.4 do ESC, as quais autorizam a aplicação de contramedidas em setores e acordos diferentes daqueles objeto do contencioso. Especificamente, o Equador solicitou autorização para suspender suas obrigações em matéria de propriedade intelectual, nos termos do Artigo 22.3(c), suspendendo a proteção de fonogramas, indicações geográficas e desenhos industriais do TRIPS, em relação aos produtos oriundos das CE. ${ }^{86}$ Isso implicava, para os árbitros, examinar, nos termos do Artigo 22.3 do ESC: (i) se a aplicação de contramedidas no GATT 1994 e no GATS - acordos violados pelas CE -, ou em outros setores do GATS, era impraticável ou ineficaz; (ii) se as circunstâncias eram suficientemente sérias para permitir o uso da alínea (c); (iii) se a importância para o Membro retaliante do comércio no setor que este sofreu anulação ou prejuízo havia sido levada em conta; (iv) se elementos econômicos mais amplos relacionados à anulação ou prejuízo, assim como as consequências econômicas mais amplas das contramedidas solicitadas haviam sido levadas em conta. ${ }^{87}$

Ao examinarem o requisito da praticabilidade e eficácia da retaliação no mesmo acordo e setor, os árbitros concentraram-se no termo "eficaz". Determinaram que o objetivo do critério está em dar poder à parte que solicita a retaliação "to ensure the impact of that suspension is strong and has the desired result, namely to induce compliance by the Member which fails to bring WTO-inconsistent measures into compliance with DSB

\footnotetext{
83 EUA - Suspensão Continuada, Relatório do Órgão de Apelação [WT/DS321/AB/R], de 16 de outubro de $2008, \S 737$.

84 http://www.wto.org/english/tratop_e/dispu_e/cases_e/ds26 e.htm, consultado em 19 de janeiro de 2011.

${ }_{85} C E-$ Bananas III, Arbitragem do Artigo 22.6, pedido original do Equador [WT/DS27/ARB/ECU], decisão de 24 de março de 2000 (CE - Bananas III (22.6 : ECU)).

$86 \quad C E-$ Bananas III (22.6: ECU), § 65.

$87 \quad C E-$ Bananas III (22.6: ECU), § 69.
} 
rulings within a reasonable period of time". ${ }^{88}$ Mais adiante, os árbitros afirmaram efetivamente que, na ausência de contramedidas praticáveis e efetivas, "the objective of inducing compliance could not be accomplished and the enforcement mechanism of the WTO dispute settlement system could not function properly". ${ }^{89}$

Os árbitros explicitamente levaram em conta a disparidade entre as duas economias, ao indicar que "[o]ne may ask whether this objective [of inducing compliance] may ever be achieved in a situation where a great imbalance in terms of trade volume and economic power exists between the complaining party seeking suspension and the other party which has failed to bring WTO-inconsistent measures into compliance with WTO law. In such a case, and in situations where the complaining party is highly dependent on imports from the other party, it may happen that the suspension of certain concessions or certain other obligations entails more harmful effects for the party seeking suspension than for the other party. In these circumstances, a consideration by the complaining party in which sector or under which agreement suspension may be expected to be least harmful to itself would seem sufficient for us to find a consideration by the complaining party of the effectiveness criterion to be consistent with the requirement to follow the principles and procedures set forth in Article 22.3". 90

Em seguida, ao analisar a necessidade de "circunstâncias suficientemente sérias" para invocação da alínea (c) do Artigo 22.3 do $E S C$, os árbitros afirmaram que a alínea (d) deve ser usada como contexto para determinação dessas circunstâncias. ${ }^{91}$ A alínea (d) prevê que devem ser levados em consideração a "importância desse comércio" para o Membro reclamante e os "elementos econômicos mais amplos".

Como elemento econômico mais amplo, os árbitros levaram em conta notadamente a pouca importância do Equador para as exportações das $\mathrm{CE}$, das quais aquele país absorvia apenas 0,1 por cento: "given the fact that Ecuador, as a small developing country, only accounts for a negligible proportion of the EC's exports of these products, the suspension of concessions by Ecuador vis-à-vis the European Communities is unlikely to

\footnotetext{
$88 \quad C E-$ Bananas III $(22.6: E C U), \S 72$.

$89 \quad C E-$ Bananas III (22.6: ECU), \$76 (sem ênfase no original).

$90 \quad C E-$ Bananas III (22.6:ECU), § 73 (nota omitida, sem ênfase no original).

$91 \quad C E-$ Bananas III $(22.6:$ ECU),$\S 81$.
} 
have any significant effect on demand for those EC exports". ${ }^{92}$ Adicionalmente, a importância do comércio de bananas para a economia do Equador, na qual esse comércio representava então 5,2\% do PIB e 24,5\% das exportações, foi considerada demonstrada. ${ }^{93}$ A única ressalva dos árbitros foi a determinação de que algum nível de contramedidas poderia ser aplicado aos bens de consumo exportados pelas CE sem prejudicar excessivamente a economia equatoriana.

Assim, a autorização foi concedida para a aplicação de contramedidas no valor de 201,6 milhões de dólares anuais. Foi determinado que essas medidas deveriam em primeiro lugar ser aplicadas suspendendo-se concessões nos setores de bens e de serviços de comércio no atacado; na medida em que estes fossem insuficientes para atingir o valor determinado pela arbitragem (sem maiores especificações), poderiam ser suspensas obrigações nos setores 1,3 e 4 do Acordo TRIPS. ${ }^{94}$ Uma observação final dos árbitros foi incluída no relatório:

"Given the difficulties and the specific circumstances of this case which
involves a developing country Member, it could be that Ecuador may
find itself in a situation where it is not realistic or possible for it to
implement the suspension authorized by the DSB for the full amount of
the level of nullification and impairment estimated by us in all of the
sectors and/or under all agreements mentioned above combined. The
present text of the DSU does not offer a solution for such an
eventuality. Article 22.8 of the DSU merely provides that the
suspension of concession or other obligations is temporary and shall
only be applied until the WTO-inconsistent measure in question has
been removed, or the Member that must implement recommendations
or rulings provides a solution to the nullification or impairment of
benefits, or a mutually satisfactory solution is reached. We trust that in
this eventuality the parties to this dispute will find a mutually
satisfactory solution." 95

Os árbitros, portanto, reconheceram que, na situação de desequilíbrio extremo entre demandante e demandado da controvérsia CE - Bananas III, o "último recurso" do ESC poderia não ser suficiente, mesmo com a exploração pelo Equador das alíneas (b) e (c) do Artigo 22.3.

\footnotetext{
$92 \quad C E-$ Bananas III (22.6: ECU), § 95.

$93 \quad C E-$ Bananas III (22.6: ECU), § 129 (sem ênfase no original).

$94 \quad C E-$ Bananas III (22.6: ECU), § 173.

$95 \quad C E-$ Bananas III (22.6:ECU), § 177 (sem ênfase no original).
} 
Como indicado anteriormente, este contencioso foi encerrado mediante uma “solução mutuamente acordada", ao final de 2009, sem a aplicação de contramedidas. ${ }^{96}$

\section{Brasil-Aeronaves, pedido original do Canadá ${ }^{97}$}

Esta decisão arbitral teve a peculiaridade de ser a primeira na qual um subsídio aparecia como a medida original condenada pelo OSC. A relevância dessa peculiaridade consiste no procedimento especial determinado pelo Artigo 4 do $A S M C$ para a solução de controvérsias. Especificamente no que concerne a contramedidas em caso de subsídios proibidos, o termo utilizado pelos Artigos 4.10 e 4.11 do $A S M C$ é "contramedidas apropriadas"; notas de rodapé apostas à expressão "apropriadas" esclarecem apenas que estas não devem ser "desproporcionais". Ao contrário do que ocorre no $E S C$, não há no $A S M C$ determinação acerca do conteúdo das contramedidas a serem aplicadas.

Ao examinar o significado de "contramedidas apropriadas", os árbitros lembraram que as contramedidas definidas no esboço do Projeto CDI servem para induzir ao cumprimento de obrigações internacionais: "a countermeasure is 'appropriate' inter alia if it effectively induces compliance". ${ }^{98}$ No caso, "effectively 'inducing compliance' means inducing the withdrawal of the prohibited subsidy". ${ }^{99}$ Se o termo "apropriadas" no ASMC não tem o mesmo significado de "equivalente" no $E S C$, é provável que o uso do termo relacionado aos subsídios proibidos deva ser considerado mais um fator agravante do que atenuante. ${ }^{100}$

Os árbitros consideraram, em seguida, que um valor de contramedidas que correspondesse ao valor do subsídio concedido seria "apropriado" nos termos do exame realizado. Diante da solicitação brasileira de que o parâmetro de "nível equivalente ao de anulação ou prejuízo" fosse utilizado, responderam os árbitros, em primeiro lugar, que o efeito multiplicador do subsídio possivelmente resultaria em um nível ainda mais alto de

\footnotetext{
$96 \quad$ Vide nota de rodapé 75 e texto que a acompanha.

97 Brazil - Export Financing Programme for Aircraft ("Brasil - Aeronaves"), Arbitragem dos Artigos 22.6 do ESC e 4.11 do ASMC, pedido original do Canadá [WT/DS46/ARB], decisão de 28 de agosto de 2000 (Brasil-Aeronaves (22.6)).

98 Brasil-Aeronaves (22.6), § 3.44 (ênfase no original).

99 Brasil-Aeronaves (22.6), § 3.45.

100 Brasil-Aeronaves (22.6), § 3.51
} 
contramedidas se adotado o critério da equivalência; ${ }^{101}$ em segundo lugar, que requerer essa equivalência quando o acordo não a exige "would be contrary to the principle of effectiveness by significantly limiting the efficacy of countermeasures in the case of prohibited subsidies". ${ }^{102}$

Adicionalmente, os árbitros aventaram a possibilidade de seguir a orientação do Artigo 22.3(a) do ESC, o qual determina que, em regra, as obrigações suspensas devem ser as mesmas do acordo inicialmente violado. Essa possibilidade, entretanto, contrariaria os objetivos do ASMC: “other countermeasures than suspension of concessions or obligations may not always be feasible because of their potential effects on other Members. This would be the case of a counter-subsidy granted in a sector where other Members than the parties compete with the products of the parties. In such a case, the Member taking the countermeasure may not be in a position to induce compliance". ${ }^{103}$ Aqui novamente se considerou que o objeto e propósito das contramedidas é o de induce compliance por parte do Membro violador, devendo as contramedidas atingi-lo de maneira a garantir a efetividade da indução, sem entretanto afetar os direitos de outros Membros.

O valor de contramedidas autorizadas nesse caso, a serem aplicadas pelo Canadá por meio de suspensão de concessões e outras obrigações no GATT 1994, no Acordo de Têxteis e no Acordo sobre Procedimentos de Licenciamento de Importações, ${ }^{104}$ foi de 344,2 milhões de dólares canadenses anuais, contra 700 milhões originalmente solicitados.

Quatro meses depois, o Brasil informou o OSC de mudanças implementadas na medida objeto da disputa, com o intuito de tornar o programa PROEX compatível com as obrigações do Brasil perante o ASMC. Não tendo concordado com as mudanças implementadas, o Canadá requereu a instauração de um painel de implementação (Artigo 21.5), o qual, todavia, em 23 de agosto de 2001 concluiu pela compatibilidade das medidas de implementação brasileiras com as recomendações do OSC.

\footnotetext{
$101 \quad$ Brasil-Aeronaves (22.6), $§ 3.54$

102 Brasil-Aeronaves (22.6), § 3.58

103 Ibid.

104 Brasil-Aeronaves (22.6), § 4.1.
} 


\section{EUA - Direitos Autorais, pedido original das $\mathrm{CE}^{105}$}

Esta decisão teve a peculiaridade de ter sido solicitada nos termos do Artigo 25 do $E S C$, pelo qual, com o acordo das partes em disputa, é permitida a arbitragem de questões específicas fora do quadro do ESC. Com mandato específico para determinar o nível de prejuízos ou anulação de benefícios das CE em virtude da Seção 110(5) da Lei de Direitos Autorais (Copyright Act) dos EUA, ${ }^{106}$ os árbitros realizaram esse exercício partindo do pressuposto de que seu trabalho servirá de base para a negociação de compensações dos EUA às CE. ${ }^{107}$

Por essa razão, o relatório dos árbitros evitou decisões em matéria de contramedidas, limitando-se ao cálculo do prejuízo: "the most appropriate way to assess the level of EC benefits nullified or impaired is to determine what EC right holders received before the enforcement of the 1998 Amendment - because historical figures are available with respect to that period - and adjust it as appropriate to take into account the evolution of the US market in the sector concerned". ${ }^{108}$

Posteriormente, após algum tempo de negociação entre EUA e CE, em 23 de junho de 2003, ambas as partes informaram ao OSC terem chegado a um arranjo temporário mutuamente satisfatório. ${ }^{109}$

\section{6. $E U A-F S C$, pedido original das $C E^{110}$}

Este caso surgiu de uma condenação do governo dos EUA pelo uso de subsídios ilegais por meio de "Foreign Sales Corporations" (subsidiárias de empresas americanas no exterior). As CE, vencedoras no caso inicial, solicitaram autorização para aplicação de retaliações no valor de 4,043 bilhões de dólares anuais ${ }^{111}$ - sendo os subsídios ilegais

\footnotetext{
105 EUA-Direitos Autorais, Arbitragem do Artigo 25, pedido original das CE[WT/DS160/ARB25/1], decisão de 9 de novembro de 2001 (EUA - Direitos Autorais (25)).

$106 \quad$ EUA-Direitos Autorais (25), § 2.2.

$107 \quad$ EUA-Direitos Autorais (25), § 2.6.

$108 \quad$ EUA - Direitos Autorais (25), § 4.10

109 Vide http://www.wto.org/english/tratop_e/dispu_e/cases_e/ds160_e.htm, último acesso em $19 \mathrm{de}$ janeiro de 2011.

$110 \quad$ United States - Tax Treatment for "Foreign Sales Corporations" ("EUA - FSC"), arbitragem dos Artigos 22.6 do ESC e 4.11 do $A S M C$, pedido original das [CE WT/DS108/ARB], decisão de 30 de agosto de 2002 (EUA - FSC (22.6)).

$111 \quad E U A-F S C(22.6), \S 1.4$.
} 
americanos calculados pelos árbitros em 4 bilhões anuais. ${ }^{112}$ Os EUA argumentaram exagero no valor solicitado, notadamente porque: (a) no caso de subsídios, as contramedidas de cada Membro deveriam ser limitadas aos efeitos no comércio daquele por aquele Membro; e (b) a forma de calcular esses efeitos deveria ser comparável à do Artigo 22.4 do ESC (equivalência). ${ }^{113}$ Os árbitros lembraram que "the relationship to be respected is precisely that of 'proportion' rather than 'equivalence". ${ }^{114}$ Realizaram uma exaustiva análise dos termos do artigo 4.10 do $A S M C$, assim como do contexto e do objeto e propósito desse artigo. A análise, específica para o caso em tela, fundou-se na proibição absoluta dos subsídios à exportação ${ }^{115}$ e na necessidade de remoção desses subsídios: ${ }^{116}$ "as we interpret Article 4.10 of the SCM Agreement, a Member is entitled to act with countermeasures that properly take into account the gravity of the breach and the nature of the upset in the balance of rights and obligations in question. This cannot be reduced to a requirement that constrains countermeasures to trade effects". ${ }^{117}$ Em consequência, argumentaram os árbitros, o valor dos subsídios - e não seus efeitos sobre o comércio deveria servir de parâmetro para aferir a resposta apropriada:

"The quantitative element of the breach in this case is, in fact, that the United States has spent approximately US\$4,000 million yearly in breach of its obligations. To our mind, each dollar is, as it were, as much a breach of the obligations of the United States as any other. Certain dollars do not become any less so - or effectively 'quarantined' from their legal status of breach of an obligation - by virtue of some other criteria (such as trade effects). To put it another way, the United States' breach of obligation is not objectively dismissed because some of the products benefiting from the subsidy are, e.g., exported to another trading partner. It is an erga omnes obligation owed in is entirety to each and every Member. It cannot be considered to be 'allocatable' across the Membership. Otherwise, the Member concerned would be only partially obliged in respect of each and every Member, which is manifestly inconsistent with an erga omnes per se obligation. Thus, the United States has breached its obligation to the European Communities in respect of all the money that it has expended, because such expenditure in breach - the expense incurredis the very essence of the wrongful act.",118

$\begin{array}{ll}12 & E U A-F S C(22.6), \S 6.10 . \\ 13 & E U A-F S C(22.6), \S 4.5 . \\ 14 & E U A-F S C(22.6), \S 5.18 . \\ 15 & E U A-F S C(22.6), \S 5.43 . \\ 16 & E U A-F S C(22.6), \S 5.53 . \\ 17 & E U A-F S C(22.6), \S 5.61 . \\ 18 & E U A-F S C(22.6), \S 6.10 \text { (notas omitidas). }\end{array}$


Diante do argumento de que essas contramedidas, aplicadas na sua inteireza pelas $\mathrm{CE}$, constituiriam uma autorização às $\mathrm{CE}$ "to de facto act erga omnes on behalf of the WTO membership", ${ }^{119}$ os árbitros lembraram tratar-se de uma controvérsia entre dois Membros apenas, e que nas circunstâncias do caso as CE eram o único Membro reclamante a solicitar a aplicação de contramedidas. ${ }^{120} \mathrm{O}$ argumento essencial, portanto, é o de que "in itself, the maintenance of the measure in violation of the United States' obligations under the SCM Agreement upsets the balance of rights and obligations between Members, and more specifically, between the United States and the European Communities". ${ }^{121}$

Diante da ausência de cumprimento por parte dos EUA no sentido de revogar os subsídios proibidos objeto da disputa, o assunto foi novamente referido pelas CE a uma arbitragem de conformidade (Artigo 21.5, ESC), a qual, em fevereiro de 2006, reafirmou que os EUA continuavam "(...) to fail to implement fully the operative DSB recommendations and rulings to withdraw the prohibited subsidies and to bring its measures into conformity with its obligations under the relevant covered agreements."122

O caso não chegou a ser referido a mais uma arbitragem do Artigo 22.6, já que, em 17 de maio de 2006, em reunião do OSC, foi registrada a implementação da decisão pelos EUA (mediante revogação da legislação), com aquiescência da suficiência dessa implementação pela CE, que anunciou ser desnecessária a aplicação de retaliação. ${ }^{123}$

\footnotetext{
$119 \quad E U A-F S C(22.6), \S 6.61$.

$120 \quad E U A-F S C(22.6), \S 6.28$.

$121 \quad E U A-F S C(22.6), \S 6.58$.

$122 E U A-F S C$, arbitragem do Artigo 21.5 do ESC, segundo recurso da CE, [WT/DS108/AB/RW2], decisão de 13 de fevereiro de 2006 (EUA - FSC (21.5) CE-2), § 100.

${ }_{123}$ Órgão de Solução de Controvérsias, Ata da Reunião de 20 de junho de 2006 [WT/DSB/M/212]: "78. The representative of the United States, speaking under "Other Business", said that the United States was very pleased to report that, on 11 May 2006, the US Congress had passed legislation to repeal the "grandfather" provisions of the American Jobs Creation Act and the ETI Act that were a subject of the recent compliance proceedings in the FSC dispute. The United States understood that the US President was expected to sign the legislation later in the course of the day. With that development, the United States understood that the United States and the EC would be able to put this dispute behind them. The United States welcomed news of recent efforts by the EC in response to the repeal and looked forward to hearing more from the EC in the course of the day.

79. The representative of the European Communities said that the EC warmly welcomed the repeal by Congress of the "grandfather" provisions of the American Jobs Creation Act. When the transition rules of that Act were to expire at the end of the year, compliance would finally be achieved in this very long saga. In recognition of these efforts, the Council of the European Union had decided on 15 May 2006, by Regulation 728/2006, to prevent the re-introduction of trade sanctions against US exports. These sanctions had been suspended during the second 21.5 compliance review, but were due to be re-introduced on 16 May. Once the US President signed the Bill, the sanctions would end. This was a positive signal not only for the bilateral relationship but also for the WTO as a whole."
} 


\section{Canadá - Aeronaves, pedido original do Brasil ${ }^{124}$}

Nesta arbitragem, chegada mais de dois anos após a autorização para retaliações em Brasil - Aeronaves, os árbitros basearam-se amplamente nas conclusões dos árbitros no caso $E U A-F S C$ acerca da natureza das contramedidas. O pedido inicial do Brasil foi o de aplicar contramedidas no valor de 3,36 bilhões de dólares, equivalente às perdas que estimava para sua indústria de aeronaves em concorrências com o produto subsidiado. Contra essa estimativa, o argumento do Canadá aceito pelo árbitros foi o de que isso resultaria num nível de contramedidas por aeronave vendida 43 vezes superior àquele determinado dois anos antes em Brasil - Aeronaves. ${ }^{125} \mathrm{Na}$ visão dos árbitros, "the large difference in levels of countermeasures on a per-aircraft basis suggests that Brazil's proposed level of countermeasures may not be appropriate". ${ }^{126}$

Com relação ao caso em exame, os árbitros examinaram o montante das exportações anuais do Canadá para o Brasil, estimadas entre 591 e 927 milhões de dólares. O valor solicitado pelo Brasil era portanto de três a seis vezes maior do que esse valor. Essa diferença tornava não apropriado o valor solicitado pelo Brasil, tendo em vista que "authorizing countermeasures would, if applied, halt such a significant proportion of trade in goods between the two parties for several years". ${ }^{127} \mathrm{O}$ argumento da gravidade da violação pareceu aos árbitros insuficiente neste caso. A necessidade de que as contramedidas fossem suficientes para induzir compliance, entretanto, mereceu exame atento:

"in addition to the level of the countermeasures, the nature of the countermeasures and the sectors subject to countermeasures have a role in determining likely compliance. In addition, other factors internal to the Member subject to the countermeasures may have an impact. While the logic underpinning countermeasures is that higher countermeasures are more likely to induce compliance than lower countermeasures, the requirement that countermeasures be 'appropriate' precludes reliance on that logic alone."128

\footnotetext{
124 Canada - Export Credits and Loan Guarantees for Regional Aircraft ("Canadá - Aeronaves"), arbitragem dos Artigos 22.6. do ESC e 4.11 do ASMC, pedido original do Brasil [WT/DS222/ARB], decisão de 17 de fevereiro de 2003 (Canadá-Aeronaves (22.6)).

125 Canadá-Aeronaves (22.6), $\$ \$ 3.39-3.41$.

126 Canadá-Aeronaves (22.6), § 3.41.

127 Canadá-Aeronaves (22.6), § 3.42 .

128 Canadá-Aeronaves (22.6), § 3.48
} 
Contra o pedido original do Brasil, no qual o valor das contramedidas era calculado em função do prejuízo sofrido, os árbitros decidiram adotar a mesma lógica de Brasil Aeronaves e EUA - FSC e utilizar como ponto de partida o valor do subsídio concedido, "subject to adjustments if necessary to ensure that the level of countermeasures is appropriate". ${ }^{129}$ Multiplicando o valor estimado do subsídio por aeronave pelo número de aeronaves vendidas, o valor total dos subsídios, levado a valor presente, foi calculado em US\$206.497.305,00. Os árbitros então consideraram os três critérios mencionados pelo Brasil que poderiam justificar um aumento desse valor: (i) a necessidade de induzir compliance; (ii) o risco de medidas-relâmpago restarem impunes; e (iii) o impacto desproporcional dos subsídios no mercado. ${ }^{130}$ Desses, apenas o primeiro foi aceito. O valor estimado inicialmente para os subsidios foi então acrescido de $20 \%$ pelos árbitros, "to take into account the fact that Canada, until now, has stated that it does not intend to withdraw the subsidy at issue and the need to reach a level of countermeasures which can reasonably contribute to induce compliance". ${ }^{131}$ Com esse acréscimo, o valor final das contramedidas autorizadas foi de US\$247.796.766,00. Uma observação final dos árbitros, dando conta da possível arbitrariedade desse cálculo, merece reprodução:“(...) adjustments such as the one we are making cannot be precisely calibrated. There is no scientifically based formula that we could use to calculate this adjustment. In that sense, the adjustment might be viewed as a symbolic one. Even so, we are convinced that it is a justified adjustment in light of the circumstances of this case and, in particular, the need to induce compliance with WTO obligations. Without such an adjustment, we would not be satisfied that an appropriate level of countermeasures had been established in this case." $" 132$

Embora tenha sido autorizada a aplicação de contramedidas, o Brasil não chegou a impô-las contra o Canadá, por acordo entre as partes.

\footnotetext{
$129 \quad$ Canadá-Aeronaves (22.6), § 3.51.

130 Canadá-Aeronaves (22.6), $\S \S 3.101-3.118$.

131 Canadá - Aeronaves (22.6), § 3.119.

132 Canadá-Aeronaves (22.6), § 3.122.
} 


\section{EUA - Lei Antidumping de 1916, pedido original das $\mathrm{CE}^{133}$}

Nesta controvérsia, em resposta à legislação americana em matéria antidumping julgada pelo OSC incompatível com o Acordo da OMC e portanto causadora de anulação ou prejuízo (nullification or impairment) às $\mathrm{CE}$-, as CE solicitaram ao OSC autorização para adotar um "regulamento-espelho". ${ }^{134}$ Árbitros e partes concordavam não caber à arbitragem examinar a natureza das contramedidas, apenas determinar se o nível da suspensão de retaliação era equivalente ao nível de anulação ou prejuízo iniciais. ${ }^{135}$

As partes discordaram com relação ao objetivo das contramedidas: enquanto as CE estimavam que "the basic purpose of the suspension of concessions or other obligations is to induce compliance of the other Member with its WTO obligations", ${ }^{136}$ os EUA sugeriram outros propósitos possíveis, como "to restore the balance of benefits under the covered agreements between the parties to the dispute". ${ }^{137} \mathrm{Na}$ resposta, os árbitros afirmaram concordar que "a fundamental objective of the suspension of obligations is to induce compliance. The fact that such suspension is meant to be temporary - as indicated in Article 22.1 - is further evidence of this purpose". ${ }^{138}$ Aceitaram também "the critically important point that the concept of 'equivalence', as embodied in Article 22.4, means that obligations cannot be suspended in a punitive manner". ${ }^{139}$

Pela primeira vez, a proposta contida no pedido de autorização para retaliação não trazia um valor numérico. Ao argumento de que a mera semelhança entre as duas medidas garante a equivalência, os árbitros lembraram que "similar or even identical measures can have dissimilar trade effects. Stated another way, similar or identical measures may not result in the required equivalence between the level of suspension and the level of nullification or impairment". ${ }^{140}$ Caso os efeitos sobre o comércio da retaliação fossem maiores que os efeitos sobre o comércio da violação, estar-se ia diante de um efeito

\footnotetext{
133 United States - Anti-Dumping Act of 1916 (“EUA - Lei Antidumping de 1916”), Arbitragem do Artigo 22.6 do ESC, pedido original das CE [WT/DS136/ARB], decisão de 24 de fevereiro de 2004 (EUA Lei Antidumping de 1916 (22.6)).

$134 \quad$ EUA - Lei Antidumping de 1916 (22.6), §§ 2.1-2.10.

135 EUA - Lei Antidumping de 1916 (22.6), § 3.7.

136 EUA - Lei Antidumping de 1916 (22.6), § 5.3.

$137 \quad$ Ibid.

$138 \quad$ EUA - Lei Antidumping de 1916 (22.6), § 5.7.

$139 \quad$ EUA - Lei Antidumping de 1916 (22.6), § 5.8.

$140 \quad$ EUA - Lei Antidumping de 1916 (22.6), 5.32.
} 
punitivo, que as contramedidas não têm. Calcular o efeito da legislação antidumping americana, entretanto, era problemático: enquanto os EUA sustentavam que o efeito seria “zero", e que a mera condenação não pode servir de prova dos efeitos, a determinação de “anulação ou prejuízo" pelo painel original criava uma presunção de anulação ou prejuízo, necessariamente superiores a zero. ${ }^{141}$

Os árbitros optaram por autorizar as CE a aplicar seu "regulamento-espelho" no limite da anulação e prejuízo sofridos. Estes, por sua vez, deveriam incluir apenas julgamentos finais contra empresas europeias em virtude da Lei Antidumping de 1916, assim como valores devidos em razão de acordos daquelas empresas com o governo norteamericano. ${ }^{142}$ Tendo em vista que a lei em questão não havia sido até então aplicada contra empresas europeias, os árbitros determinaram que qualquer aplicação futura ensejaria o direito das CE de retaliar em igual montante: "The 1916 Act is WTO-inconsistent 'as such', and each application of the Act further nullifies or impairs benefits accruing to the European Communities". 143

Em 3 de dezembro de 2004, foi finalmente anunciada a revogação pelo Congresso norte-americano da Lei Antidumping de 1916, sem necessidade de aplicação de contramedidas pelas CE. ${ }^{144}$

\section{EUA - Emenda Byrd, pedidos originais de Brasil, Canadá, CE, Chile, Coreia, Japão, México e Índia ${ }^{145}$}

Neste caso, a Emenda Byrd (oficialmente a Lei de Compensação por Dumping e Subsídios Continuados de 2000) dos EUA havia sido entendida pelo OSC como sendo incompatível com as obrigações assumidas no GATT 1994 e no ASMC. Propondo

\footnotetext{
$141 \quad$ EUA-Lei Antidumping de 1916 (22.6), § 4.48-5.50.

$142 \quad$ EUA - Lei Antidumping de 1916 (22.6), § 7.7.

143 EUA - Lei Antidumping de 1916 (22.6), § 7.8.

$144 \quad$ "At the DSB meeting on 17 December 2004, the representative of the United States stated that on 3 December 2004, the US president had signed into law the Miscellaneous Trade and Technical Corrections Act of 2004, which included a provision repealing the 1916 Act. Consequently, the United States stated that it had brought itself into compliance with the DSB's recommendations and rulings in this dispute." Relatório Anual, Órgão de Solução de Controvérsias, [WT/DSB/39], emitido em 11 novembro de 2005, p. 31.

145 United States - Continued Dumping and Subsidy Offset Act of 2000 ("EUA - Emenda Byrd'), pedidos originais de Brasil [WT/DS217/ARB/BRA], CE [WT/DS217/ARB/EEC], Chile [WT/DS217/ARB/CHL], Coreia [WT/DS217/ARB/KOR], Japão [WT/DS217/ARB/JPN] e Índia [WT/DS217/ARB/IND], e Canadá [WT/DS234/ARB/CAN] e México [WT/DS234/ARB/MEX], decisão de 31 de agosto de 2004 (EUA - Emenda Byrd (22.6)).
} 
metodologias diferentes para o cálculo, os demandantes - com exceção do Chile solicitaram ao OSC a aplicação de contramedidas em valor anual, para cada solicitante, equivalente às "compensações" pagas no ano anterior pelos EUA aos seus produtores domésticos. ${ }^{146}$ Isso equivalia, observaram os árbitros, a adotar para uma Arbitragem do Artigo 22.6 do ESC uma abordagem - correspondência entre valor da retaliação e valores desembolsados em virtude da medida ilegal - que só havia sido adotada em arbitragens envolvendo o Artigo 4.10 e 4.11 do $A S M C .{ }^{147}$

É interessante observar que os árbitros rejeitaram o modelo proposto pelos Membros demandantes (Chile excetuado), em parte, porque esses Membros sugeriam que cada um deles fosse autorizado a aplicar contramedidas fundadas no valor total desembolsado pelos EUA a cada ano, sem levar em conta apenas os efeitos dessa medida sobre cada Membro tomado individualmente. Os demandantes alegaram que, tendo a violação em questão sido julgada como uma violação e portanto uma causa de anulação ou prejuízo aos Membros, “and since a right generally applies erga omnes, each Member should be entitled to retaliate up to the full effect of the violation". ${ }^{148}$

Tendo em vista a diferença entre as fórmulas empregadas para descrever o nível de retaliação nesses dois acordos ("equivalentes" ou "apropriadas"), os árbitros rejeitaram a abordagem: "this argument fails to recognize the distinction between the violation of a right and the consequence thereof, i.e., nullification or impairment within the meaning of Article XXIII:1 of GATT 1994". ${ }^{149}$ Concluíram que "it would be difficult, in situations other than those relating to prohibited subsidies, to conclude that any disbursement pursuant to an illegal measure automatically causes nullification or impairment at least equivalent to the total amount disbursed". 150

Para calcular o valor de contramedidas autorizadas, os árbitros fizeram referência aos casos anteriores e elegeram os efeitos sobre o comércio como o parâmetro apropriado

\footnotetext{
146 EUA-Emenda Byrd (22.6), $\S 1.4$ (os parágrafos, quando diferentes, serão identificados pelo nome do país).

${ }_{147} \quad E U A-$ Emenda Byrd (22.6), § 3.14 (Canadá, Chile: 3.12 ).

$148 E U A-$ Emenda Byrd (22.6), § 3.33 (Canadá: 3.31; Chile: n/a).

$149 E U A-$ Emenda Byrd (22.6), § 3.34 (Canadá: 3.32; Chile: n/a).

150 EUA - Emenda Byrd (22.6), § 3.49 (Canadá: 3.47; Chile: 3.44).
} 
para embasar o cálculo. ${ }^{151}$ Quando confrontados com o argumento de que as contramedidas têm por função induzir o compliance, responderam:

"The concept of 'inducing compliance' was first raised in the EC Bananas III (US) (Article 22.6 - EC) arbitration and has been referred to since in other arbitrations. However, it is not expressly referred to in any part of the DSU and we are not persuaded that the object and purpose of the DSU - or of the WTO Agreement - would support an approach where the purpose of suspension of concessions or other obligations pursuant to Article 22 would be exclusively to induce compliance. Having regard to Articles 3.7 and 22.1 and 22.2 of the DSU as part of the context of Articles 22.4 and 22.7, we cannot exclude that inducing compliance is part of the objectives behind suspension of concessions or other obligations, but at most it can be only one of a number of purposes in authorizing the suspension of concessions or other obligations. By relying on 'inducing compliance' as the benchmark for the selection of the most appropriate approach we also run the risk of losing sight of the requirement of Article 22.4 that the level of suspension be equivalent to the level of nullification or impairment." 152

Os árbitros então declararam indesejável a simplificação implícita em usar os valores pagos à indústria como se fossem o mesmo que os efeitos sobre o comércio. ${ }^{153}$ Consideraram ainda a necessidade de evitar aceitar pedidos muito remotos, muito especulativos ou não significativamente quantificados. ${ }^{154} \mathrm{E}$ decidiram recorrer a um modelo econômico que permitisse, fundado num valor claramente identificável - os pagamentos realizados em virtude da legislação americana - examinar em que medida esses pagamentos podem causar prejuízos ou anulação de benefícios dos demandantes. ${ }^{155}$

Sobre o uso desse modelo, afirmaram:

"We recognize that, in relying on an economic model in this arbitration, we may be breaking new grounds. This impression may be correct to the extent that we base our determinations on the results of this model. However, we note that economic modelling has already been applied in the US - FSC (Article 22.6 - US) arbitration. We are also mindful that applying economic models in arbitrations under Article 22.6 of the DSU may make such proceedings more complex and costlier. We acknowledge that economic analysis requires expertise that may not be readily available to all WTO Members. We do not believe, however, that this should be a reason to deprive ourselves of a 
means to reach a credible result through a transparent process in complex cases such as this one. Rather, we see the option of using economic models in Article 22.6 arbitrations as creating an opportunity to ensure full cooperation from the parties and, hence, more precise and credible results where the alternative may be to choose between simplistic and perhaps irreconcilable approaches." $" 156$

Aplicado o modelo econômico, os árbitros concluíram que o nível de anulação ou prejuízo para cada Membro demandante poderia ser estimado, a cada ano, como o valor total de pagamentos efetuados em virtude da Emenda Byrd por medidas antidumping ou medidas compensatórias impostas a importações vindas daquele Membro no ano anterior, multiplicado por $0,72 .{ }^{157}$

As observações finais dos árbitros, por tratarem das maiores dificuldades que o procedimento de contramedidas definido pelo ESC enfrentou nesse caso, valem a reprodução:

"6.2 As mentioned above, the DSU does not expressly explain the purpose behind the authorization of the suspension of concessions or other obligations. On the one hand, the general obligation to comply with DSB recommendations and rulings seems to imply that suspension of concessions or other obligations is intended to induce compliance, as has been acknowledged by previous arbitrators. However, exactly what may induce compliance is likely to vary in each case, in the light of a number of factors including, but not limited to, the level of suspension of obligations authorized.

6.3 On the other hand, the requirement that the level of such suspensions remain equivalent to the level of nullification or impairment suffered by the complaining party seems to imply that suspension of concessions or other obligations is only a means of obtaining some form of temporary compensation, even when the negotiation of compensations has failed.

6.4 In other words, it is not completely clear what role is to be played by the suspension of obligations in the DSU and a large part of the conceptual debate that took place in these proceedings could have been avoided if a clear "object and purpose" were identified.

6.5 The WTO dispute settlement system authorizes Members to challenge a law as such, i.e. irrespective of whether it has been applied or not. The "classical" approach based on an assessment of the trade effect of a given measure may not always contribute to the

\footnotetext{
$156 \quad$ EUA - Emenda Byrd (22.6), § 3.79 (Canadá: 3.77; Chile: 3.74, nota omitida).

157 EUA - Emenda Byrd (22.6), § 3.151 (Canadá: 3.149; Chile: 3.147). E, para todos, § 5.2.
} 
identification of the actual level of nullification or impairment, in particular if no instances of application had arisen at the time. This may be because the trade effect of a measure may be difficult to assess due to the lack of verifiable figures. We are of the view that, while parties share a duty to cooperate with the Arbitrator in the establishment of the facts, there is no reason a priori to sanction the requesting party or the respondent if supporting figures are difficult or impossible to find. We believe that this is a situation that has to be addressed in order to reach a decision on what may be achievable through recourse to suspension of obligations in such cases.

6.6 In this arbitration, we have interpreted the concept of nullification or impairment, inter alia, from the terms of Article XXIII of GATT 1994 and Article 3.8 of the DSU. We believe, however, from the extensive discussion of this concept by the parties, that the actual meaning of this provision is disputed and needs to be addressed in the appropriate forum.

6.7 Finally, we note that an issue that arose as a consequence of following the approach whereby each party would be granted the right to suspend obligations exclusively in relation to its own exports is that there will remain disbursements under the CDSOA in respect of goods from other Members and non-WTO Members for which no suspension of concessions or other obligations have been authorized." 158

Em virtude desse relatório, o OSC autorizou a aplicarem contramedidas os seguintes Membros: Brasil, Chile, CE, Índia, Japão, Coreia, Canadá e México. Desses, há notícia de que, utilizando-se da fórmula acima, as CE tenham retaliado em US\$ 27,81 milhões, o Japão em US\$ 52,10 milhões e o Canadá em US\$ 11,16 milhões. Não há notícia de que Brasil, Chile, Índia, Coreia do Sul ou México tenham efetivamente aplicado contramedidas contra os EUA.

Em reunião de 17 de fevereiro de 2006, os EUA informaram sobre a aprovação do Deficit Reduction Act, em $1^{\circ}$ de fevereiro de 2006, pelo Congresso norte-americano, com subsequente sanção presidencial em 8 de fevereiro de 2006. Diversos Membros demandantes e terceiras partes discordaram da conformidade de tal medida com as recomendações do OSC. Em vista disso, CE e Japão continuam a aplicar contramedidas contra os EUA, conforme notificações de novos produtos sujeitos a contramedidas apresentadas por CE (28 de abril de 2006, 19 de abril de 2007, 3 de abril de 2008, 23 de

158 Em EUA - Emenda Byrd (22.6) (notas omitidas) 
abril de 2009 e 22 de abril de 2010) e pelo Japão (22 de agosto de 2006, 23 de agosto de 2007, 29 de agosto de 2008, 14 de agosto de 2009 e 25 de agosto de 2010). ${ }^{159}$

\section{EUA - Jogos e Apostas [DS285], pedido original de Antígua e Barbuda ${ }^{160}$}

Neste caso, após conseguir a condenação da política norte-americana de restrição de jogos e apostas condenada pelo OSC, e não tendo os EUA implementado o relatório em tempo hábil, Antígua e Barbuda requereu o direito de aplicar contra os EUA contramedidas no valor de 3,443 bilhões de dólares, em serviços e em direitos de propriedade intelectual. ${ }^{161}$

Numa nota preliminar acerca do objetivo das contramedidas, os árbitros afirmaram que "while the purpose of suspension of concessions or other obligations under the covered agreements as foreseen in Article 22.1 of the DSU is to 'induce compliance' by the Member concerned with its obligations under the covered agreements, this does not mean that such suspension may be authorized beyond what is 'equivalent' to the level of nullification of impairment". ${ }^{162}$

O counterfactual proposto por Antígua e Barbuda tomava como base uma situação em que os EUA removeriam todas as restrições a seu mercado de jogos e apostas. Entretanto, argumentaram os árbitros, a proibição de jogos e apostas implementada pelos EUA havia sido considerada pelo Órgão de Apelação como defensável em virtude do Artigo XVI(a) do GATS (proteção da moral pública). ${ }^{163}$ A única razão de condenação da política americana pelo Órgão de Apelação havia sido a proibição de que estrangeiros oferecessem dentro dos EUA serviços de apostas em corridas de cavalos, permitidos aos provedores de serviços domésticos. ${ }^{164}$ Por essa razão, apenas esses serviços foram levados em conta no counterfactual elaborado.

\footnotetext{
159 Órgão de Solução de Controvérsias, Ata da Reunião de 31 de agosto de 2010 [WT/DSB/M/286]. United States - Measures Affecting the Cross-Border Supply of Gambling and Betting Services (“EUA - Jogos e Apostas"), arbitragem do Artigo 22.6 do ESC, pedido original de Antígua e Barbuda [WT/DS285/ARB], decisão de 21 de dezembro de 2007 (EUA - Jogos e Apostas (22.6)).

$161 \quad$ EUA - Jogos e Apostas (22.6), § 1.5.

$162 \quad E U A-J o g o s$ e Apostas (22.6), § 2.7.

$163 \quad E U A-J o g o s$ e Apostas (22.6), § 3.57.

$164 \quad E U A-J o g o s$ e Apostas (22.6), § 3.58.
} 
A opinião dissidente de um dos árbitros (que contudo aceitou nesse ponto o voto da maioria), incluída no relatório, propunha uma solução diferente:

"In the view of this arbitrator, the objective of inducing compliance cannot lead to suspension being authorized in excess of equivalence with the level of nullification or impairment of benefits, as foreseen in Article 22.6 of the DSU, and this must remain the benchmark against which the proposed level of suspension is assessed. At the same time, however, in a situation where different means of compliance might form the basis of a counterfactual in order to determine the level of nullification or impairment of benefits, the complaining party would not be prevented from selecting a counterfactual that may lead to a higher level of nullification or impairment than others, provided that such counterfactual is reasonable.

It should be borne in mind, in this respect, that the Member concerned has had the opportunity to comply with the rulings at issue, and that the very reason for the existence of countermeasures under the DSU is to induce compliance with the covered agreement that has not taken place within the period foreseen in the DSU. In these circumstances, the complainant is by necessity obliged to make certain assumptions as to how compliance might have taken place. This has no implications, however, as to the means through which the Member concerned might actually choose to comply in the future, possibly including, in this case, through the adoption of measures that involve a restriction to trade fully consistent with the provisions of Article XIV of GATS."165

O modelo aplicado pelos árbitros, nas bases escolhidas pela maioria, elegeu duas possíveis metodologias para calcular o prejuízo total sofrido por Antígua e Barbuda em virtude da proibição de jogos pelos EUA. Aplicando-se uma delas, o prejuízo de Antígua e Barbuda seria de 304 milhões; aplicada a outra, o prejuízo era calculado em 196 milhões. Ajustando-se esse valor para a entrada de possíveis concorrentes com a abertura à concorrência desse serviço, verificando-se a porção do mercado de apostas correspondente às apostas em corridas de cavalos e computando-se um possível crescimento da demanda americana, os árbitros chegaram ao valor final de 21 milhões de dólares.

Ao avaliar a praticabilidade e eficácia das contramedidas em serviços de recreação, bem como no GATS em geral, os árbitros levaram em conta o argumento de que a porção das exportações dos EUA dirigidas a Antígua e Barbuda era menor que 0,02\%; essas mesmas exportações corresponderiam a 48,9\% das importações do Membro retaliante. ${ }^{166}$

\footnotetext{
$165 E U A-J o g o s$ e Apostas (22.6), $\S \S 370-371$ (sem ênfase no original).

166 EUA-Jogos e Apostas (22.6), § 4.2.
} 
Concluíram que, de um lado, os consumidores de Antígua e Barbuda incorreriam custos incertos para alterar seus fornecedores de serviços de recreação; ${ }^{167}$ de outro, o impacto potencial para os fornecedores americanos de quaisquer restrições à exportação de serviços e recreação para Antígua e Barbuda seria praticamente inexistente. ${ }^{168}$

Ao avaliar a praticabilidade e eficácia das contramedidas em serviços em geral, os árbitros aceitaram o argumento norte-americano de que "general statements relating to the size of the complaining party's economy or the relative size of the economies of both parties do not justify a departure from the requirements of Article 22.3 of the DSU. Rather, the complaining party is required, in all cases, to follow the specific sequence of steps provided in this provision and to make a determination in respect of each of its elements as relevant". ${ }^{169}$ Entretanto, observaram que Antígua e Barbuda havia fornecido dados e estimativas, e que os serviços de mais alto valor importados dos EUA (transporte, viagens e seguros) estavam diretamente ligados à indústria do turismo, da qual o país depende. ${ }^{170}$ Os contra-argumentos oferecidos pelos EUA não foram suficientes para demonstrar que havia maneiras praticáveis e eficazes de Antígua e Barbuda aplicar contramedidas em serviços. Esses mesmos fatores, acrescidos da condição insular do país, do seu baixo desenvolvimento e da pouca diversidade da sua economia, exacerbavam as dificuldades em aplicar retaliações que prejudiquem provedores de serviço norteamericanos, configurando-se as circunstâncias suficientemente graves que permitem o recurso à alínea (c) do Artigo 22.3(c). Os árbitros observaram que "the heavy reliance of Antigua's economy on the very sectors that would be candidates for retaliation under the GATS increases the likelihood that an adverse impact would arise for Antigua itself, including for low-wage workers". ${ }^{171}$

Como em outras ocasiões, os árbitros recusaram o pedido dos EUA de que fosse exigido de Antígua e Barbuda apresentar previamente a maneira como aplicaria a retaliação. Basearam-se para isso no Artigo 22.7 do $E S C$, que não lhes permite examinar a natureza das retaliações. Autorizaram, assim, Antígua e Barbuda a aplicar 21 milhões de dólares em contramedidas contra os EUA, nos seguintes setores do Acordo TRIPS:

\begin{tabular}{ll}
\hline 167 & EUA-Jogos e Apostas (22.6), $\$ 4.59$. \\
168 & EUA-Jogos e Apostas (22.6), § 4.62. \\
169 & EUA - Jogos e Apostas (22.6), § 4.91. \\
170 & EUA - Jogos e Apostas (22.6), §4.94. \\
171 & EUA - Jogos e Apostas (22.6), § 4.114.
\end{tabular}


Section 1: Copyright and related rights

Section 2: Trademarks

Section 4: Industrial designs

Section 5: Patents

Section 7: Protection of undisclosed information. ${ }^{172}$

Embora tenha sido concedida a autorização, não há notícia de sua aplicação por Antígua e Barbuda, tampouco de que os EUA tenham tomado providências visando a tornar a medida questionada em conformidade com as recomendações do OSC.

\section{EUA - Algodão [DS267], pedido original do Brasil ${ }^{173}$}

Neste caso, os árbitros emitiram dois relatórios com suas decisões, em razão das duas bases diferentes que autorizavam o pedido brasileiro de aplicação de contramedidas. De um lado, o Brasil desejava aplicar contramedidas contra subsídios proibidos: o Step 2, que justificaria contramedidas num único montante de 350 milhões de dólares; e o GSM102, que justificaria contramedidas no valor de 1,294 bilhão de dólares anuais (valor para o ano fiscal de 2006). ${ }^{174}$ De outro lado, pedia autorização para aplicar contramedidas contra diversos subsídios acionáveis, no valor anual de 1,037 bilhão de dólares anuais. ${ }^{175}$ No primeiro caso, além do Artigo 22.6 do ESC, era base procedimental o Artigo 4.11 do $A S M C$; no segundo caso, o pedido se fundamentava no Artigo 22.6 do ESC e no Artigo 7.10 do $A S M C$.

No primeiro procedimento, os árbitros logo descartaram a possibilidade de que o Brasil pudesse impor contramedidas com relação ao programa Step 2, o qual havia expirado dois anos antes. Ao argumento do Brasil de que essa expiração havia ocorrido após o fim do PRT, os árbitros lembraram a função das contramedidas: "the suspension of concessions or other obligations, as a remedy, is available where compliance has not been

\footnotetext{
$172 \quad$ EUA - Jogos e Apostas (22.6), § 5.6.

173 United States - Subsidies on Upland Cotton ("EUA - Algodão"), Arbitragem dos Artigos 22.6 do ESC e 4.11 do ASMC, pedido original do Brasil [WT/DS267/ARB/1], decisão de 31 de agosto de 2009 (EUA - Algodão (22.6, 4.11)); United States - Subsidies on Upland Cotton, Arbitragem dos Artigos 22.6 do ESC e 7.10 do ASMC, pedido original do Brasil [WT/DS267/ARB/2], decisão de 31 de agosto de 2009 (EUA-Algodão $(22.6,7.10))$.

$174 \quad$ EUA-Algodão $(22.6,4.11), \S 2.6$.

175 EUA-Algodão (22.6, 7.10), § 4.1.
} 
achieved, and in order to induce such compliance". ${ }^{176}$ Especificaram que, dado esse caráter, os remédios da OMC não se aplicam a infrações passadas:

"In light of our determinations above that countermeasures are a temporary remedy available only where compliance has not been achieved and with a view to inducing such compliance, and that full implementation is preferred to the suspension of concessions or other obligations, we do not consider that there would be a legitimate basis to such countermeasures as requested by Brazil in relation to past payments made until the repeal of Step 2, in the absence of a multilateral determination of non-compliance in relation to such payments and independently of any continuing situation of noncompliance."

Em relação aos subsídios proibidos GSM102, os árbitros não concordaram com o argumento do Brasil de que "the term 'countermeasures' necessarily connotes, in and of itself, an intention to refer to retaliatory action that 'goes beyond the mere rebalancing of trade interests". ${ }^{178}$ Aceitaram, entretanto, que "the term 'countermeasures', in the SCM Agreement, describes measures that are in the nature of countermeasures as defined in the ILC's Draft Articles on State Responsibility". ${ }^{179}$ Contra a posição dos EUA, que desejavam que fosse utilizado como base para o valor das contramedidas o montante gasto pelo governo norte-americano com subsídios, os árbitros determinaram que mesmo no caso dos subsídios, incompatíveis per se com a normativa da OMC, tal incompatibilidade se funda no alto potencial desses instrumentos para causar distorções no comércio. ${ }^{180}$ Por isso, e para evitar o excesso e a desproporcionalidade, ${ }^{181}$ dessas medidas que são um "last resort", ${ }^{182}$ os árbitros decidiram utilizar o prejuízo sofrido pelo Brasil como base para a determinação do valor da retaliação:

\footnotetext{
$176 \quad$ EUA - Algodão $(22.6,4.11), \S 3.45$.

$177 \quad E U A-$ Algodão $(22.6,4.11), \S 3.50$.

$178 \quad$ EUA - Algodão $(22.6,4.11), \S 4.38$.

179 EUA - Algodão $(22.6,4.11), \S$ 4.41. No mesmo sentido: "we therefore find that the term "countermeasures" essentially characterizes the nature of the measures to be authorized, i.e. temporary measures that would otherwise be contrary to obligations under the WTO Agreement and that are taken in response to a breach of an obligation under the SCM Agreement" (Ibid., § 4.42, grifos no original).

${ }_{180}$ EUA - Algodão (22.6, 4.11), § 4.56: "The trade-distorting impact of the prohibited subsidy at issue on the complaining Member effectively reflects the manner in which the economic position of the complaining party to the dispute has been disrupted and harmed by the illegal measure. This provides a measure of the extent to which the balance of rights and obligations between the parties has been upset by the granting and maintenance of the prohibited subsidy at issue. This is necessarily, in our view, a central consideration in determining what may constitute 'appropriate countermeasures' to be applied between such two parties."

181 EUA - Algodão (22.6, 4.11), § 4.85: "We therefore understand this proportionality requirement to be a protection against excessive countermeasures."

${ }^{182}$ EUA - Algodão (22.6, 4.11), § 4.86.
} 
“...countermeasures, in order to be 'appropriate', should bear some relationship to the extent to which the complaining Member has suffered from the trade-distorting impact of the illegal subsidy. Countermeasures are in essence trade-restrictive measures to be taken in response to a Member's application of a trade-distorting measure that has been determined to nullify or impair the benefits accruing to another Member. Countermeasures that would ensure a relationship of proportionality between the extent to which the trade opportunities of the Member applying the countermeasures has been affected and the extent to which the trade opportunities of the violating Member will in turn be adversely affected would notionally restore the balance of rights and obligations arising from the covered agreements that has been upset between the parties. This would ensure a proper relationship between the level of the countermeasures and the circumstances out of which the dispute arises." 183

Os árbitros consideraram também que o mero objetivo de induce compliance não altera a necessidade de verificar o dano específico causado ao Membro que adota as retaliações. ${ }^{184}$ Diante da possibilidade de que essa limitação pudesse terminar por impedir o objetivo inicial de induce compliance, argumentaram:

"It might be suggested that our Member-specific measurement of the trade-distorting impact of prohibited subsidies when assessing a countermeasure under Article 4.10 of the SCM Agreement limits the extent of countermeasures which can be imposed and dulls the effectiveness of such measures thereby making them less powerful for the purpose of inducing compliance. However we are in no doubt that this is the correct interpretation of Article 4.10, for all of the reasons we have mentioned. Whilst an authorized countermeasure addressing only the impacts on a complaining Member will always be of a lesser quantum than the one which would address the impacts on all Members, this does not mean that authorized countermeasures will not be effective or will not induce compliance. The degree of the impact on the complaining Member might be quite significant, and the countermeasure itself might be quite powerful depending on the trade relationship of the parties concerned.

We also note that it is open to all Members who consider that their interests are affected by the violating measure to initiate dispute settlement proceedings and ultimately, if the dispute should reach that stage, to seek 'appropriate' countermeasures that would take due account of the circumstances in that dispute. We note in this respect the terms of Article 4.11 of the DSU, which provides that a Member whose request to be joined in consultations initiated by another Member has been declined, and who considers that benefits accruing to it are being nullified or impaired, may initiate its own consultations. We also note 
the possibility of several Members presenting multiple complaints about the same factual situation as foreseen in Article 9 of the DSU. In the event of multiple complaints, the levels of 'appropriate' countermeasures that could be attained would accordingly increase, thereby increasing the contribution that the countermeasures can make to 'inducing compliance.'."185

Os árbitros consideraram então o modelo proposto pelo Brasil, e lembraram que os prejuízos causados a outros Membros não necessariamente equivaliam ao valor do subsídio, podendo ser inclusive bastante superiores a este. ${ }^{186}$ Rejeitaram tanto a proposta brasileira, ${ }^{187}$ quanto a norte-americana, ${ }^{188}$ e elaboraram o próprio modelo econômico, com base na distorção ao comércio causada pelo GSM102: "a consideration of the tradedistorting impact of the subsidy, which both parties have de facto relied on in their respective approaches (albeit in different forms), constitutes the most pertinent expression of the consequences arising from the violation, for the purposes of quantifying 'appropriate' countermeasures". ${ }^{189}$ Aplicado esse modelo, em boa parte baseado na proposta inicial do Brasil, chegaram os árbitros a um valor de retaliação que, tomando como base o ano de 2006, seria de 147,4 milhões de dólares. ${ }^{190}$

Na decisão referente aos subsídios acionáveis, uma dificuldade inicial surgiu com relação às contramedidas - que nesse caso devem ser "proporcionais (commensurate) ao grau e à natureza dos efeitos danosos que se tenham verificado". ${ }^{191} \mathrm{O}$ extenso exame dessa expressão pelos árbitros atingiu resultados semelhantes ao exame da expressão "apropriados": o essencial, na determinação do valor da autorização, é a "correspondence between the countermeasure and the degree and nature of the adverse effects. The objective of inducing compliance must be seen to arise from the ability of a Member to obtain an authorization, and not from an exaggeration of its permitted amount". 192

Os árbitros rejeitaram a tentativa do Brasil de aplicar contramedidas correspondentes à distorção causada pelos subsídios americanos no mercado global, entendendo que cada Membro deve ser autorizado a retaliar na medida em que vir 
comprometido o mercado para seus próprios produtos. Confrontados com o argumento do Brasil de que isso poderia tornar inútil a obrigação de implementação no caso de efeitos adversos globais, responderam: "The obligation of the United States in terms of implementation remains to remove the adverse effects determined to exist (or withdraw the subsidy). This is a distinct question from the question of the quantum of countermeasures that Brazil is entitled to seek, as the complaining Member whose interests are adversely affected by the existence of this significant price suppression". ${ }^{93}$

Para chegar ao resultado do dano causado pelos subsídios norte-americanos aos produtores brasileiros, os árbitros utilizaram amplamente o modelo proposto pelo Brasil e concluíram que os efeitos adversos dos subsídios no mundo todo somavam 2,905 bilhões de dólares para o ano de 2005. ${ }^{194}$ Tendo em vista a porção da produção mundial de algodão que cabia ao Brasil (5,1\%), determinaram que os efeitos adversos sobre o Brasil eram de 147,3 milhões de dólares para o ano de 2005 - valor máximo das contramedidas a serem aplicadas pelo Brasil em função dos subsídios acionáveis mantidos pelos EUA. Com isso, o valor somado das contramedidas autorizadas foi calculado em 294,7 milhões; ao mesmo tempo, os árbitros criaram fórmulas para determinar, ano a ano, o valor dos danos causados ao Brasil em função dos subsídios norte-americanos. Com isso, obteve-se um "valor de retaliação" variável ano a ano conforme o maior ou menor impacto a cada ano dos subsídios sobre o mercado mundial de algodão.

De posse de uma medida quantitativa, os árbitros examinaram o pedido do Brasil de autorização para aplicar as contramedidas suspendendo obrigações nos Acordos TRIPS e GATS. O primeiro argumento brasileiro, de que a regulamentação das contramedidas pelo $A S M C$ - por ser lex specialis - excluiria os critérios de prioridade expressos no Artigo 22.3 do ESC, foi rejeitado pelos árbitros. Estes consideraram que a expressão "contramedidas" e seus qualificativos no $A S M C$ determinavam o nível de contramedidas; ${ }^{195}$ o tipo de contramedidas, por outro lado, deveria ser definido por uma interpretação conjunta do ASMC e do ESC: “The various paragraphs under Article 4[7] of the SCM Agreement may not be read in isolation from the DSU. [They] replace the equivalent rules of the DSU only to the extent that they differ from and are incompatible

\footnotetext{
$193 \quad E U A-$ Algodão $(22.6,7.10), 4.89$ (grifo no original).

$194 \quad E U A-$ Algodão $(22.6,7.10), 4.193$.

$195 E U A-$ Algodão $(22.6,4.11) \& E U A-$ Algodão $(22.6,7.10), \S 5.25$.
} 
with such rules". ${ }^{196}$ Passaram, por isso, a examinar o argumento dos EUA de que o Brasil não seguiu os princípios e procedimentos do Artigo 22.3 do ESC. ${ }^{197}$

Em primeiro lugar, os árbitros lembraram que o Brasil teria de cumprir os dois requisitos da alínea (c) do Artigo 22.3 se desejasse retaliar em outros acordos, já que o GATT 1994 contém um único setor (bens). Portanto, cumpria à arbitragem verificar (i) se a retaliação em bens era efetivamente impraticável ou ineficaz; e (ii) se as circunstâncias eram sérias o suficiente. ${ }^{198}$ Com relação ao primeiro requisito, os árbitros lembraram o propósito da retaliação cruzada: "this provision seeks to ensure that the complaining party will be in a position to actually have recourse to the authorized remedy, and thus enable it to contribute to inducing compliance, as is its legitimate purpose". ${ }^{199}$ Com relação ao segundo requisito, os árbitros utilizaram os parâmetros da alínea (d) do Artigo 22.6 do $E S C$ : a importância do comércio afetado e o contexto econômico mais amplo. Entretanto, tendo em vista a diferença entre o valor total de contramedidas solicitado pelo Brasil (2,681 bilhões de dólares) e o valor final (294,7 milhões), os pressupostos utilizados pelo Brasil no seu pedido de contramedidas em TRIPS e GATS ficavam prejudicados. ${ }^{200}$ Os árbitros teriam portanto de refazer a análise fundados no novo valor.

Analisando o comércio bilateral Brasil-Estados Unidos, os árbitros observaram que o Brasil importava 18,7 bilhões de dólares anuais em bens dos $\mathrm{EUA}^{201}$ tornando a retaliação em bens em princípio praticável. ${ }^{202}$ Entretanto, argumentou o Brasil, 95\% dessas importações eram de bens de capital; dentre os bens de consumo, $86 \%$ eram suprimentos médicos e educacionais, alimentos, bens automotivos e armas, "sectors where any raising of barriers would entail serious and unreasonable costs to the Brazilian economy". ${ }^{203}$ Embora os árbitros tenham aceitado a maior parte dos argumentos do Brasil em relação à importância dos setores envolvidos, calcularam que existia margem suficiente para o Brasil aplicar contramedidas em bens de consumo em até 407,9 milhões de dólares anuais sem incorrer em custos irrazoáveis. ${ }^{204}$ Por isso, contramedidas até esse valor deveriam ser

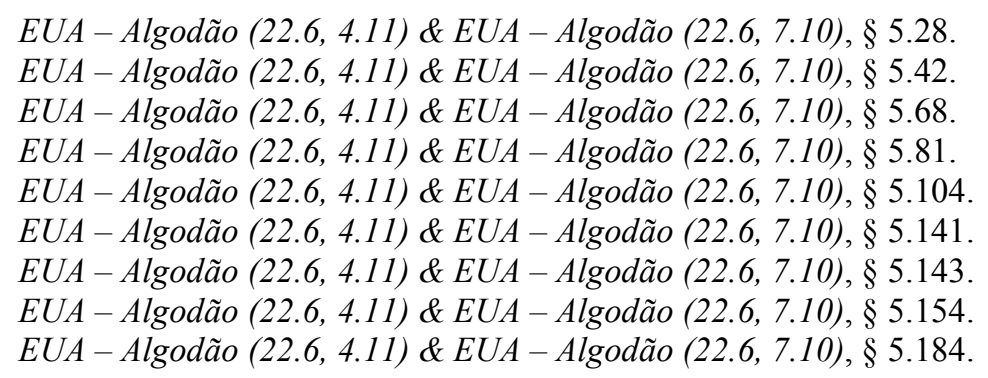


necessariamente aplicadas em bens. Entretanto, no caso de o valor dos subsídios americanos subir, aumentariam - segundo a fórmula contida no relatório - os prejuízos anuais sofridos pelo Brasil. Se isso significasse um valor de contramedidas autorizadas superior aos 407,9 milhões de dólares anuais (valor de 2007), passaria a ser legítimo o argumento brasileiro de que retaliar apenas em bens não é praticável ou eficaz. ${ }^{205}$

Com relação à seriedade das circunstâncias, dois argumentos foram retidos pelos árbitros. O primeiro, o de que as distorções causadas pelos subsídios norte-americanos tornaram-se um elemento estrutural do mercado mundial dos produtos envolvidos; ${ }^{206} \mathrm{o}$ segundo, o da impraticabilidade ou ineficácia de suspensões de concessões pelo Brasil acima do limiar determinado pela arbitragem - elemento que contribuía não só para tornar a retaliação de altos valores impraticável ou ineficaz, mas também para tornar as circunstâncias graves o suficiente para justificar a retaliação cruzada. ${ }^{207}$ Os árbitros, assim, concederam ao Brasil a possibilidade de retaliar em serviços e propriedade intelectual, na medida em que, para um determinado ano, o dano causado pelo total dos subsídios americanos fosse superior à capacidade brasileira de retaliar em bens.

Dada a autorização para o Brasil aplicar contramedidas contra os EUA, o Brasil iniciou preparativos para aplicá-las, tendo anunciado primeiramente a aplicação de contramedidas sobre a importação de produtos, em conformidade com a estrutura de contramedidas aprovada pelo OSC (para tanto, publicou em consulta pública uma minuta de resolução da CAMEX - Câmara de Comércio Exterior, pela qual seria majorada alíquota do imposto de importação de uma série de produtos). ${ }^{208}$ Posteriormente, o Brasil também anunciou a aplicação de contramedidas sobre direitos de propriedade intelectual, tendo também feito publicar minuta de resolução da CAMEX com indicação dos direitos passíveis de contramedidas. ${ }^{209}$

A Resolução CAMEX n 15/2010, de 5 de março de 2010 (publicada no D.O.U. em 8 de março 2010), chegou a ser publicada, com uma vacatio legis de 30 dias (artigo $4^{\circ}$ ), mas foi posteriormente suspensa pela Resolução CAMEX n ${ }^{\circ}$ 43/2010, de 17 de junho

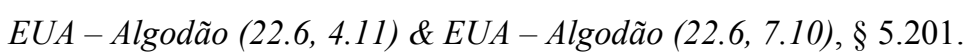

EUA - Algodão $(22.6,4.11) \&$ EUA - Algodão (22.6, 7.10), § 5.220.

EUA - Algodão (22.6, 4.11) \& EUA - Algodão (22.6, 7.10), § 5.221.

Resolução no. 74, de 06 de novembro de 2009, publicada no D.O.U. de 9 de novembro de 2009.

Resolução $n^{\circ}$ 16, de 12 de março 2010, publicada no D.O.U. de 15 de março de 2010 
de 2010 (publicada no D.O.U. em 18 de junho de 2010) em razão do anúncio de um acordo entre Brasil e EUA - Framework for a Mutually Agreed Solution to the Cotton Dispute in the World Trade Organization (WT/DS267) (“Framework") -, o qual foi notificado ao OSC, sem o efeito todavia de uma solução mutuamente satisfatória para o contencioso, prevendo não a revogação dos subsídios, mas medidas compensatórias (dentre as quais, um pagamento de contribuição para desenvolvimento da cultura algodoeira no Brasil). O Brasil assumiu o compromisso de, enquanto o Framework estiver em vigor, não aplicar contra os EUA as contramedidas aprovadas pelo OSC. ${ }^{210}$

\section{Conclusão}

A análise das decisões revela, como mostra a Tabela 1 abaixo, que em todos os relatórios até hoje "induce compliance" foi citado pelos árbitros como sendo ao menos um dos objetivos essenciais das contramedidas da OMC. Em nenhum deles foi aceito o argumento de que entre os objetivos das contramedidas poderia estar um "reequilíbrio" de direitos e obrigações:

Tabela 1 - Objetivos das Contramedidas por Arbitragem

\begin{tabular}{|c|c|c|c|c|c|c|}
\hline Data & Caso & Nome & $\begin{array}{c}\text { Induce } \\
\text { Compliance }\end{array}$ & $\begin{array}{c}\text { Induce } \\
\text { Compliance } \\
+ \\
\text { Equivalence } \\
\end{array}$ & $\begin{array}{c}\text { Induce } \\
\text { Compliance + } \\
\text { Compensation }\end{array}$ & $\begin{array}{l}\text { Rebalancing/ } \\
\text { Compensation }\end{array}$ \\
\hline \multicolumn{7}{|c|}{ Casos não envolvendo subsídios } \\
\hline 9 de abril de 1999 & DS27 & $C E-$ Bananas III & & $\mathrm{X}$ & & \\
\hline 12 de julho de 1999 & $\begin{array}{l}\text { DS26/ } \\
\text { DS48 }\end{array}$ & CE-Hormônios & & $\mathrm{X}$ & & \\
\hline 24 de fevereiro de 2000 & DS27 & CE - Bananas III & $\mathrm{X}$ & & & \\
\hline 24 de fevereiro de 2004 & DS136 & $\begin{array}{l}\text { EUA-Lei } \\
\text { Antidumping de } \\
1916\end{array}$ & & $\mathrm{X}$ & & \\
\hline 21 de dezembro de 2007 & DS285 & $\begin{array}{l}\text { EUA-Jogos e } \\
\text { Apostas }\end{array}$ & & $\mathrm{X}$ & & \\
\hline
\end{tabular}

\begin{tabular}{|c|c|c|c|c|}
\hline Casos envolvendo subsídi & & & & \\
\hline 28 de agosto de 2000 & DS46 & Brasil-Aeronaves & $\mathrm{X}$ & \\
\hline 30 de agosto de 2002 & DS108 & $E U A-F S C$ & $\mathrm{X}$ & \\
\hline 31 de agosto de 2004 & $\begin{array}{l}\text { DS217/ } \\
\text { DS234 }\end{array}$ & $\begin{array}{l}\text { EUA-Emenda } \\
\text { Byrd }\end{array}$ & & $\mathrm{X}$ \\
\hline
\end{tabular}

* A decisão dos árbitros em EUA - Direitos Autorais não foi incluída por não abordar o tema.

210 EUA - Algodão, Comunicação Conjunta de Brasil e EUA, [WT/DS267/45], de 31 de agosto de 2010. 
Quanto aos resultados, há uma clara distinção entre as declarações dos árbitros acerca do objetivo das retaliações nas arbitragens envolvendo subsídios - em que o próprio $A S M C$ substitui as contramedidas "equivalentes" do ESC por contramedidas "apropriadas" ou "proporcionais" (commensurate) - e as declarações feitas naquelas arbitragens que envolvem violações de outros acordos.

Nas arbitragens envolvendo subsídios, todas as vezes menos uma (4 em 5) se considerou que o objetivo das contramedidas é unicamente o de induce compliance. Esse objetivo foi responsável pelo aumento do nível de contramedidas autorizadas (Canadá Aeronaves) e também pela autorização para retaliação cruzada (EUA - Algodão). Apenas na arbitragem de EUA - Emenda Byrd os árbitros aceitaram a possibilidade de que as contramedidas tenham o objetivo de compensar os Membros que as aplicam pelo nãocumprimento por outro Membro de uma obrigação. Não se pode excluir que tenha pesado nessa alteração de discurso dos árbitros o fato de a retaliação ter sido solicitada por oito Membros da OMC - com importantes representantes dos grandes e médios players da organização -, que solicitavam, baseados em $E U A-F S C$, o direito de retaliar cada um em valor correspondente à totalidade dos gastos dos EUA com seu programa de subsídio.

Nos casos não envolvendo subsídios, em todas as vezes menos uma (4 em 5) determinou-se que os subsídios tinham a função de induce compliance, limitada contudo pela exigência de equivalência entre as contramedidas e a anulação ou prejuízo sofridos. Novamente, o contexto em que se deu a única exceção é bastante revelador: os árbitros de $C E$ - Bananas III (pedido original do Equador) enfatizaram o induce compliance como objeto e propósito das contramedidas, ${ }^{211}$ deixando claro que o faziam em razão da diferença de desenvolvimento econômico entre as partes. ${ }^{212}$

A análise dos relatórios arbitrais estabelece como objetivo central das contramedidas da OMC a indução ao cumprimento dos acordos. A equivalência com o grau de anulação ou prejuízo aparece, é certo, como limitação ao exercício desse objetivo, mas não como objetivo paralelo. Nenhum dos relatórios menciona a possibilidade de "reequilíbrio" ser um objetivo da retaliação, embora os EUA tenham insistido em alguns

$211 C E-$ Bananas III, $\S \S 72-76$. O relatório faz referência à necessidade de verificar a equivalência mandato mesmo dos árbitros. É no momento de definir a função das contramedidas que os árbitros esclarecem: "the object and purpose of Article 22 ... is to induce compliance" (Ibid., § 76).

$212 \quad C E-$ Bananas III, $§ 77$. 
casos nessa interpretação. O único relatório que procura mitigar esse objetivo de indução ao cumprimento (EUA - Emenda Byrd) o faz num contexto em que, a seguir a "jurisprudência" anterior, poderiam ser aplicadas contramedidas verdadeiramente desproporcionais do ponto de vista do Membro retaliado.

Estando superada a caracterização do propósito das contramedidas como sendo de indução ao cumprimento, pode-se concluir que uma alteração no mecanismo das contramedidas do ESC visando a torná-lo mais eficaz no tocante à indução ao cumprimento significaria um aprimoramento desse mecanismo. A limitação a ser observada - a se seguirem o espírito das contramedidas no ESC como no Projeto CDI - é que a alteração não pode implicar, para o Membro retaliado, um dano desproporcional àquele criado pela violação inicial. Será preciso que a coletivização da retaliação ocorra de forma a que a quantidade total de retaliação autorizada seja proporcional à anulação ou prejuízo criados pela violação inicial.

Nesse sentido, é importante sinalizar que a maioria das soluções apresentadas para o problema de enforcement no SSC/OMC parte do pressuposto de que o objetivo essencial do sistema seja o cumprimento dos acordos. Breve análise de tais propostas é o tema do próximo Capítulo. 


\section{PROPOSTAS PARA SOLUÇÃO DO PROBLEMA DO COMPLIANCE NO SSC/OMC: UMA TIPOLOGIA}

\section{A. Introdução}

A maioria das soluções apresentadas para o problema de enforcement no SSC/OMC parte do pressuposto - devidamente comprovado - de que o objetivo essencial do sistema seja o cumprimento dos acordos.

Uma tipologia das propostas para a alteração das regras do ESC relativas às retaliações pode ser estabelecida por referência à inconsistência ou insuficiência percebida nas regras atuais.

Em primeiro lugar, há propostas que partem do pressuposto de que o mecanismo atual é via de regra positivo, mas insuficiente para alcançar os objetivos da OMC, e portanto precisa ser aprimorado. Esse aprimoramento responde a duas falhas percebidas no mecanismo atual, uma particular e outra geral. A falha particular consiste na dificuldade, e talvez impossibilidade, de os países em desenvolvimento aplicarem retaliações eficazes contra os países desenvolvidos. A falha geral consiste na pouca utilidade das retaliações para promover o desejado cumprimento das obrigações da OMC.

Em segundo lugar, há propostas que vêem essa falha geral não como um defeito conjuntural do atual mecanismo, mas como o próprio resultado de o "último recurso" disponível para promover a liberalização comercial consistir justamente na aplicação de uma restrição comercial. Estas propostas procuram então resolver ou mitigar o que seus autores percebem como uma contradição lógica entre um dos objetivos da OMC - a liberalização progressiva do comércio internacional - e o efeito restritivo de comércio das retaliações aplicadas por meio da elevação tarifária. A alteração sugerida, em consequência, deve atingir o próprio mecanismo atualmente utilizado para responder às violações dos acordos, para substituí-lo por um outro mecanismo que não afete o objetivo de liberalização comercial.

Em suma, as alternativas apresentadas ao mecanismo de retaliação são diversas, mas podem ser divididas didaticamente em dois tipos: aquelas nas quais o mecanismo 
alternativo visa a compensar o Membro prejudicado, de um lado, e, de outro, aquelas cujo mecanismo visa a produzir compliance sem as desvantagens percebidas na retaliação.

\section{Alternativas Compensatórias}

As alternativas compensatórias visam a produzir efeitos positivos para o Membro prejudicado e, portanto, aparentam ter por base a concepção de reequilíbrio do contrato. Em realidade, muitas vezes se trata de um reconhecimento de que, em alguns casos, a retaliação teria dificuldades em produzir compliance - por exemplo, quando uma economia pequena vence uma grande economia (como em CE - Bananas III ou EUAJogos e Apostas), ou quando a medida violadora é importante para o Membro violador por motivos não comerciais (como em $C E$ - Hormônios). Nesses casos, argumenta-se que as retaliações seriam inúteis ou simplesmente improdutivas, e que mais valeria reforçar as obrigações de compensação.

\section{a) Compensação Obrigatória}

Contrastada com o objetivo proclamado da OMC de progressiva liberalização do comércio por meio da redução tarifária, a autorização para retaliação parece contraditória. Com base nessa observação, Pauwelyn propôs substituir esse sistema pela compensação obrigatória. Se efetuada por meio de uma redução nas tarifas do Membro violador, essa compensação aumentaria a liberalização, beneficiando tanto o Membro compensado como todos os demais - incluindo, se adotada a teoria liberal, aquele que oferece a retaliação. ${ }^{213}$ Embora não se possa forçar a realização desta compensação, argumenta Pauwelyn, é perfeitamente possível torná-la obrigatória, submetendo sua forma e seu valor à arbitragem - assim como já ocorre com a retaliação. ${ }^{214}$

A proposta de compensação obrigatória ganhou impulso após a arbitragem de retaliação do Equador no caso Bananas III, em 2000. Se retaliasse impondo tarifas extras a bens, o Equador se prejudicaria mais do que as CE. A retaliação em propriedade intelectual, por outro lado, ainda que autorizada, parecia de difícil implementação - em especial porque deveria restringir seus efeitos ao território equatoriano - e sua aplicação

\footnotetext{
213 Pauwelyn (2000), p. 345.

214 Ibid.
} 
poderia terminar por prejudicar o Equador muito mais do que às $\mathrm{CE}$. $\mathrm{O}$ caso explicitou o quão pouco eficaz era o "último recurso" da OMC quando aplicado por um país pequeno contra um Membro de grande porte. No seu comunicado de 2002, o próprio Equador adotou a proposta da compensação obrigatória:

"Instead of authorizing the suspension of concessions or other obligations, the DSB (...) could decide that the Member concerned must obligatorily compensate the complaining party. The noncomplying Member must submit a compensation package to the next session of the DSB for its approval (...) If no compensation is submitted(...) it will be understood that the Member concerned intends to compensate in cash." 215

A questão da compensação monetária será examinada a seguir. A primeira parte da proposta do Equador consiste na obrigatoriedade de uma compensação comercial. Compensação comercial significa, na prática, a redução pelo Membro violador de tarifas em áreas que interessam ao Membro reclamante - observada a regra da Nação-MaisFavorecida (NMF).

Kym Anderson ${ }^{216}$ analisa as razões pelas quais acredita que essa proposta teria dificuldades para ser implementada. Em primeiro lugar, está a configuração atual do $E S C$ : não é possível obter uma arbitragem sobre compensação da mesma maneira que se pode fazer com a retaliação. A segunda se refere à necessidade de respeitar a regra da NMF: baixar as tarifas pode causar perdas políticas importantes no Membro violador, sem provocar uma melhora correspondente para o Membro compensado. A terceira é mais estrutural: a compensação dá ao Membro violador controle sobre o processo, deixando com este o poder de decretar o cumprimento das medidas e cessar a compensação obrigando o Membro compensado a ingressar com novo painel pelo Artigo 21.5 do ESC. ${ }^{217}$

Quanto à primeira dificuldade, bastaria alterar o texto do ESC para que os árbitros determinassem simplesmente o nível de anulação ou prejuízo, em vez de arbitrar o nível de retaliação autorizado. Já existe proposta nesse sentido, de Filipinas e Tailândia, a qual entretanto não elimina a possibilidade de o Membro prejudicado solicitar retaliação. ${ }^{218}$

\footnotetext{
215 "Contribution of Ecuador to the Improvement of the Dispute Settlement Understanding of the WTO", comunicado do Equador [TN/DS/W/9], 8 de julho de 2002.

216 Anderson (2002).

217 Ibid., p. 126.

$218 \mathrm{WT} / \mathrm{MIN}(01) / \mathrm{W} / 3, \S 3^{\circ}$.
} 
Quanto à segunda questão, há proposta da Jamaica no sentido de a compensação ser concedida conforme acordo entre os Membros envolvidos, na forma de acesso ampliado ao mercado do Membro desenvolvido ("Increased market access in agreed sectors of the developed-country Member"). ${ }^{219}$

Solucionar o terceiro problema parece mais problemático. É possível retornar à noção de Pauwelyn de que não é necessário que uma conduta seja passível de enforcement para que seja obrigatória. O texto de 2003 do Embaixador Péter Bálas da Hungria ${ }^{220}$ adota essa postura na proposta de artigo $22.2 \mathrm{bis}$, pelo qual pedidos de compensação deveriam ser respondidos em 20 ou 30 dias, ao fim dos quais o Membro prejudicado teria imediatamente a possibilidade de solicitar retaliação. É possível adotar a mesma solução para o fim das concessões adicionais, dando ao Membro compensado o direito de iniciar retaliações unilateralmente, dentro do valor permitido, se entender que a compensação foi suspensa.

Como observa William Davey, é possível promover o uso da compensação, mas isso não muda o fato de que esta requer o assentimento ou a cooperação da parte violadora - o que não pode ser forçado. ${ }^{221} \mathrm{O}$ impacto dessa proposta, por isso, tende a ser reduzido; em última instância, ela não alteraria a distribuição de poder dentro da organização.

\section{b) Compensação Monetária}

A proposta de compensação monetária - isto é, de pagamento de uma soma pelo Membro violador ao prejudicado - foi também lançada por Pauwelyn, apresentada como uma forma de garantir que o setor ou indústria que sofreu o dano se beneficie da compensação. ${ }^{222}$ Essa proposta tem forte apoio dos países em desenvolvimento (liderados pelo Brasil), os quais, como lembra Hudec, realizaram proposta nesse sentido ainda no tempo do GATT, em 1966, sem contudo obter a concordância dos países desenvolvidos. ${ }^{223}$

\footnotetext{
219 "Contribution by Jamaica to the Doha Mandated Review of the Dispute Settlement Understanding", comunicado da Jamaica [TN/DS/W/21], 8 de outubro de 2002, ponto 9.

220 TN/DS/9, pp. 3-19.

$221 \quad$ Davey (2004), p. 23.

$222 \quad$ Pauwelyn (2000), p. 346.

223 "Brazil's 1977 proposals sought to reintroduce some of the additional demands that had been rejected in 1966 - chiefly, a more active, prosecutorial role for the GATT Secretariat, and stronger remedies for developing country complaints, such as collective retaliation or money damages" (Hudec (1993), p. 42). $\mathrm{Na}$ nota de rodapé 34 da obra Hudec (1993), encontra-se a seguinte referência: "For the earlier 1966 proposals along these lines, see GATT, BISD $14^{\text {th }}$ Supp. 18, pp. 139-140 (1966)".
} 
A proposta foi novamente apresentada pelo Brasil em 1977, embora não tenha ganho suporte como da última vez. ${ }^{224}$

Já na fase da OMC, em 2002, o Quênia, em nome do Grupo Africano, propôs que "compensation should prominently reflect the need for monetary compensation to be continually paid pending and until the withdrawal of the measures". ${ }^{225}$ Especificamente voltada para os casos envolvendo países em desenvolvimento, a proposta foi formalizada no ano seguinte com o texto abaixo:

"if the case is one brought by a developing-country Member against a developed-country member, the DSB may recommend monetary and other appropriate compensation taking into account the injury suffered. The quantification of the injury and compensation shall be computed as from the date of the adoption of the measure found to be inconsistent with covered agreements until the date of withdrawal.",226

A decisão do OSC constituiria assim um documento de atribuição de danos, engendrando para o Membro violador uma obrigação internacional de pagar ao Membro prejudicado a quantia determinada pelo órgão. Esse sistema se inspira naquele utilizado no âmbito da União Europeia, no qual uma penalidade financeira pode ser imposta a um Membro que se recuse a cumprir um julgamento do Tribunal de Justiça da União Europeia.

Bronckers e van den Broek identificam no sistema atual diversos defeitos: os remédios atuais: (i) são meramente teóricos, no caso da compensação comercial, ou simplesmente contraprodutivos, no caso da retaliação; (ii) não oferecem alívio àqueles setores efetivamente prejudicados pela violação; (iii) prejudicam inocentes no país violador; e (iv) são difíceis de implementar, em especial se a retaliação for de valor elevado. ${ }^{227}$ Argumentam os autores que a adoção da compensação financeira soluciona todos esses problemas, lembrando que sistemas semelhantes existem no $\operatorname{CIRDI}^{228}$ e no

224 "And finally, the Brazilian Framework proposal for stronger sanctions on behalf of developing countries found no more support in 1977 than it had in 1966." (Hudec (1993), p. 42).

225 "Negotiations on the Dispute Settlement Understanding", proposta do Grupo Africano [TN/DS/W/15], 9 de setembro de 2002, p. 3.

226 "Text for the African Group: Proposals on Dispute Settlement Understanding Negotiations", comunicado do Quênia [TN/DS/W/42], 24 de janeiro de 2003.

227 Bronckers e Van den Broeck (2005), p. 103-104.

228 Centro Internacional para Resolução de Disputas sobre Investimento. Vide Convenção sobre a

Solução de Disputas sobre Investimentos entre Estados e Nacionais de Outros Estados, assinada em

Washington, DC, em 18 de março de 1965, arts. 53-55. 
NAFTA $^{229}$ para controvérsias entre investidores e Estados, ${ }^{230}$ que esse sistema foi aplicado no Tribunal Irã-EUA e que inclusive houve experiência com arbitragem de compensação na própria $\mathrm{OMC}$, entre EUA e CE. ${ }^{231}$

Segundo Kyle Bagwell, a possibilidade de compensação monetária ao Membro prejudicado traz um ganho de eficiência; isso porque a compensação tarifária, ao ser aplicada de maneira não discriminatória (NMF), beneficia também terceiros Membros. Ao excluir da equação cálculos como a porcentagem de mercado do Membro prejudicado e o potencial de crescimento de mercado deste, esse mecanismo facilitaria a negociação entre prejudicado e violador e permitiria mais soluções negociadas. ${ }^{232}$

Joel Trachtman analisa as regras da OMC pela ótica da Law and Economics, enxergando semelhanças entre as regras da organização e o direito dos contratos anglosaxão. Sob seu ponto de vista, o direito da OMC se distingue da proibição do genocídio ou da guerra de agressão, tratando-se de direito instrumental: não deve ser cumprido a qualquer custo, mas apenas na medida em o compliance aumentar o bem-estar. ${ }^{233}$ Para tanto, o sistema de "remédios" deve ter natureza compensatória, de forma a que um membro prejudicado seja indenizado no mesmo nível dos danos causados pela violação, calculados tanto retrospectiva quanto prospectivamente. ${ }^{234}$ Num nível ótimo, essa indenização deixaria o Membro prejudicado indiferente entre o compliance e a indenização, liberando um Membro para descumprir o acordo sempre que isso produza para este mais ganhos do que o valor pago ao prejudicado (que equivale ao prejuízo deste). Com isso, haveria um ganho líquido para a economia global.

Jide Nzelibe critica a proposta de compensações financeiras, entendendo que esta adota implicitamente uma visão benigna do que motiva os Estados Membros. ${ }^{235}$ Considera que os políticos no Estado violador não teriam qualquer incentivo para fazer recair sobre os beneficiários da violação o custo da compensação financeira. ${ }^{236} \mathrm{O}$ grupo que assegurou

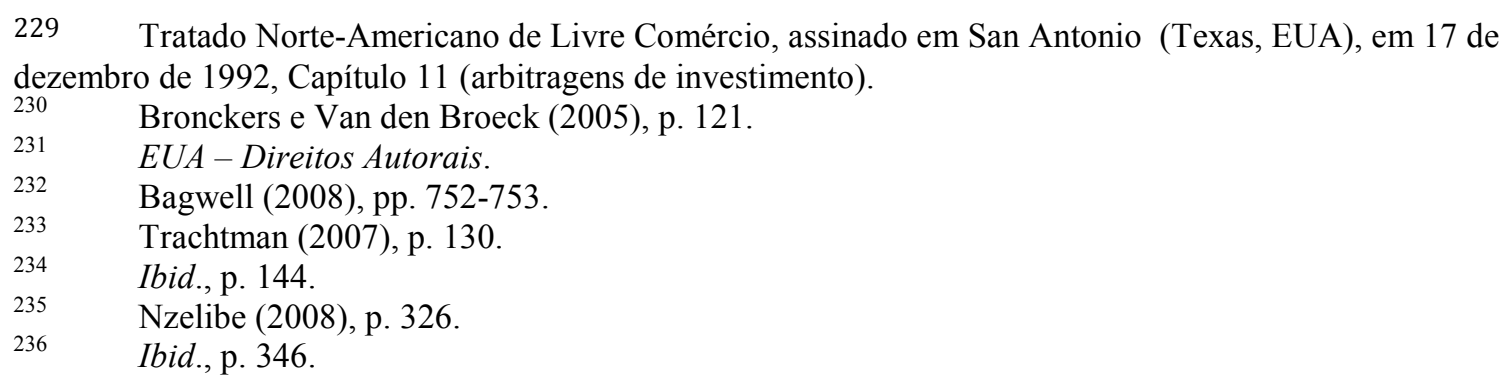


a primeira violação provavelmente faria recair sobre toda a população o custo da violação continuada, terminando com o incentivo atualmente produzido pela concentração dos custos em indústrias sensíveis, escolhidas pelo Membro retaliante. Por outro lado, argumenta, a criação do mecanismo de compensações financeiras incentivaria litigância com a finalidade de obter financiamento para medidas governamentais genéricas, portanto desvinculada do objetivo de terminar com a violação presente e prevenir violações futuras. $^{237}$

Todas essas propostas de compensação estão sujeitas à mesma crítica de Davey -requerem cooperação do Membro inicialmente violador. Charnovitz aponta ainda que um governo que deseje cumprir a norma e pagar uma multa dificilmente adotará um comportamento que gere essa multa. ${ }^{238}$ Trachtman considera esse argumento, mas lembra que há experiências de cash remedies tanto nas arbitragens de investimento do NAFTA quanto em acordos de liberalização comercial assinados pelos EUA com Chile, Cingapura e Austrália. $^{239}$

Esse debate, entretanto, deixa de considerar o maior risco dessa medida, como observado por Reto Malacrida, ${ }^{240}$ por Alan Wolff ${ }^{241}$ e por Davey: ${ }^{242}$ justamente o de que seja politicamente aceitável pagar as multas e, em, consequência os países ricos passem a comprar a liberação de suas obrigações na OMC. Wolff aceita que esse mecanismo seja utilizado para reduzir o dano de medidas incompatíveis com a $\mathrm{OMC}$ em casos em que o cumprimento pareça impossível (como em CE - Hormônios). Davey, por outro lado, propõe que se vincule o valor da multa ao tamanho da economia do violador, que se implementem multas retrospectivas para incentivar compliance imediato e que além disso o valor seja reavaliado periodicamente, talvez aumentando com o tempo. ${ }^{243}$ Gregory Shaffer, finalmente, considera que se deve, de um lado, determinar valores progressivamente crescentes para os países desenvolvidos e de outro limitar esse remédio aos casos em que países em desenvolvimento vençam países desenvolvidos. ${ }^{244}$

\begin{tabular}{ll}
\hline 237 & Ibid., p. 349. \\
238 & Charnovitz (2001), p. 282. \\
239 & Trachtman (2007), pp. 164-165. \\
240 & Malacrida (2008), p. 18. \\
241 & Wolff (2008), p. 802. \\
242 & Davey (2008), p. 126. \\
243 & Ibid. \\
244 & Shaffer (2003), pp. 42-43.
\end{tabular}


Uma última alternativa é considerar que, em determinados casos, o noncompliance deve ser acomodado no sistema, já que advém de uma escolha da parte. Nessa visão, adotada por David Collins, as novas barreiras deveriam ser contrabalançadas por um sistema que compensasse os perdedores, como ocorre no direito do investimento: a parte que investiu esperando ver o contrato cumprido é reembolsada, retornando-se a um "estado de coisas pré-contrato". ${ }^{245} \mathrm{Na}$ prática, o autor propõe um "remédio" de pagamentos decrescentes do Membro violador, correspondentes aos investimentos realizados por exportadores do Membro prejudicado com a finalidade de se aproveitar do compromisso violado. ${ }^{246}$ Segundo o autor, esse sistema levaria, de um lado, a atingir o objetivo de previsibilidade e segurança postulado pelo ESC e, de outro, a realizar o "propósito geral da OMC de otimização dos recursos". 247

\section{Abordagens Alternativas de Enforcement}

Não sendo incompatíveis com as alternativas compensatórias (nem, na prática, com a retaliação), as alternativas de enforcement apresentadas visam a atingir o objetivo de compliance dentro da OMC contornando os problemas identificados no atual "último recurso".

\section{a) Abordagem gerencialista}

Charnovitz propõe mais atenção à abordagem gerencialista adotada por outras organizações internacionais, considerando a abordagem atual da OMC coercitiva e estatocêntrica demais. ${ }^{248} \mathrm{~A}$ abordagem que propõe baseia-se expressamente na percepção de Abram e Antonia Chayes ${ }^{249}$ de que o compliance é promovido mais eficazmente por meio de processos gerencialistas, utilizando uma formulação normativa "dialética" e "instrumentos positivos" como transparência de informação, relatórios, monitoramento, treinamento e procedimentos de revisão periódica - possivelmente com participação de organizações não-governamentais - ONGs. ${ }^{250} \mathrm{~A}$ ideia central por trás da proposta é a de que o comportamento dos Estados "can be changed more easily by the power of

\footnotetext{
245 Collins (2009), p. 242 ("a pre-contractual state of affairs").

$246 \quad$ Ibid., p. 244.

247 Ibid. ("the WTO's overall purpose of resource optimization").

248 Charnovitz (2001), p. 832.

249 Chayes e Chayes (1995).

$250 \quad$ Charnovitz (2001), p. 828.
} 
persuasion than by the persuasion of power". ${ }^{251}$ Procura-se então emular a estratégia utilizada em tratados ambientais e de direitos humanos, pregando-se maior transparência, abertura a indivíduos e diálogo pós-relatório com ONGs e a comunidade empresarial dos países violador e prejudicado.

Com acerto, Charnovitz reconhece, entretanto, que a OMC já se utiliza dessas ferramentas, com um sistema sofisticado de revisão de implementação (além do periódico Mecanismo de Revisão de Políticas Comerciais); poder-se-ia acrescentar que já há grande publicidade dos relatórios, e que o fato de ONGs e o setor empresarial não terem assento na sala do OSC não exclui esses atores do debate público interno - possivelmente o essencial para gerar compliance. Charnovitz lembra ainda que há possibilidade de as técnicas de public shaming terem efeito reverso, gerando no público do Estado violador uma atitude defensiva ou nas ONGs um posicionamento de que a regra é defeituosa (ou interpretada por árbitros ilegítimos!) e a violação continuada deve ser permitida. Esses riscos se justificariam, contudo, pelo argumento de que "ultimately the WTO cannot succeed without public support earned through robust debate". 252

\section{b) Cassação de direitos}

Uma possibilidade adicional é a de que sejam cassados direitos dos Membros em falta com suas obrigações. A questão que se põe é que remover um Membro das negociações e não lhe permitir se opor ao consenso na tomada de decisões importantes parece minar o princípio essencial dessa forma de tomada de decisão e, com isso, uma parte importante da legitimidade da OMC. Poder-se-ia também suspender cooperação técnica, mas isso parece pouco razoável: de um lado, apenas os Membros menos desenvolvidos poderiam ser atingidos; de outro, essa suspensão provavelmente reduziria a capacidade do Membro violador de alterar sua legislação para cumprir as regras da OMC.

Por isso, Davey identifica no uso do SSC/OMC o maior potencial para suspensão de direitos - já que, se um Membro não acata as decisões do sistema quando perde, "simples noções de justiça" 253 indicam que esse Membro não deveria poder invocar esse

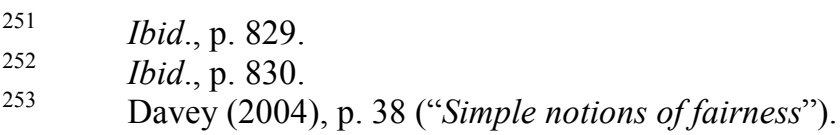


mesmo sistema contra os demais. $\mathrm{O}$ autor afirma que seria possível criar um sistema no qual os diferentes direitos exercidos no seio do OSC fossem progressivamente cassados, mas considera irrealista crer que os Membros estariam dispostos a abrir mão desses direitos - os quais são, afinal, a sua garantia de que todos os outros direitos serão respeitados. $^{254}$

Wolff acrescenta que, se efetivamente implementado, um tal sistema criaria uma licença a todos os Membros para tomar medidas incompatíveis com as regras da OMC contra o Membro violador, o qual ganharia status de pária. Acredita que o resultado possível é que o Membro que perdeu seus direitos derivados do ESC poderia deixar a organização ou minar completamente o sistema da OMC, algo nada desejável. ${ }^{255}$

O Equador, em sua primeira proposta de reforma, defendeu a suspensão do direito de invocar o ESC para Membros violadores que não oferecessem compensação aos prejudicados, com a finalidade de "preservar a credibilidade do mecanismo". ${ }^{256}$ Entretanto, no momento de formalizar sua proposta, abandonou essa possibilidade em favor de um cálculo diferenciado de anulação ou prejuízo em favor dos países em desenvolvimento. ${ }^{257}$ A impossibilidade de utilização do $E S C$, na realidade, equivaleria a tornar tábua rasa o quanto disposto no Artigo 23 do $E S C$, um artigo pedra de toque do SSC/OMC (e de grande importância ao final da Rodada Uruguai), pois tornou obrigatório e exclusivo o recurso ao $\mathrm{SSC} / \mathrm{OMC}$ quando se pretenda verificar a compatibilidade de medidas com os Acordos da $O M C$ ou aplicar medidas retaliatórias contra medidas com eles incompatíveis.

\section{c) Efeito Direto das Decisões da OMC}

Como é regra no direito internacional, as obrigações da OMC são dirigidas aos Estados (e outros Membros): eventuais violações produzem efeitos apenas na esfera internacional. Ou seja, não deriva de uma recomendação ou decisão do OSC qualquer direito para os particulares afetados pela medida violadora. Dar às obrigações e decisões da OMC "efeito direto" significaria alterar esse quadro, permitindo aos entes não-estatais reclamar diretamente dentro dos sistemas judiciários internos o cumprimento das regras da

\footnotetext{
$254 \quad$ Davey (2004), p. 38.

255 Wolff (2008), p. 806.

256 TN/DS/W/9, p. 5 ("in order to preserve the mechanism's credibility").

257 TN/DS/W/33, p. 4.
} 
OMC. Essa ideia se inspira na experiência da União Europeia, na qual decisões da organização em determinados temas produzem direito exigível nos tribunais internos dos Membros.

Ernst-Ulrich Petersmann defende essa proposta, argumentando pela necessidade de novas formas de "citizen-driven, democratic participation, legitimization, and judicial enforcement of international rules". ${ }^{258}$ Argumenta que a natureza cosmopolita do direito do comércio internacional e do modelo concorrencial esposado pela OMC deveria estar juridicamente refletida nos direitos internos. Assim, deveria ser permitido a produtores, investidores, comerciantes e consumidores contestarem violações das regras da OMC nos tribunais internos de cada Membro - sem necessidade de recorrer aos governos. ${ }^{259} \mathrm{De}$ acordo com o autor, essas medidas reduziriam os custos de transação, aumentariam o rule of law, promoveriam a participação democrática no direito do comércio internacional e limitariam o "protecionismo judicial" nos tribunais internos. ${ }^{260}$

O obstáculo essencial a essa proposta parece ser a revolução completa que ela representaria nas relações entre direito interno e direito internacional. A própria União Europeia, utilizada por Petersmann como inspiração, frustrou a expectativa de aceitação de efeitos diretos das decisões da OMC no seio daquela organização. A tese de que, por ser a UE uma organização internacional, poderia ocorrer incorporação automática de outras regras de direito internacional foi derrotada, em primeiro lugar, em relação ao próprio direito da OMC. ${ }^{261}$ Em seguida, com a decisão do Tribunal de Justiça da União Europeia no caso Kadi, ${ }^{262}$ um possível "efeito direto" do direito internacional nos Estados-Membros da UE, estendendo a todos os tratados firmados pela UE o efeito direto que produz o direito daquela organização, parece ter sido afastado. ${ }^{263}$

Ainda que fosse determinado um "efeito direto" para o direito da OMC, haveria dificuldades de implementação. Como observa Charnovitz, dada a vagueza tanto dos acordos como das decisões, um tribunal interno teria dificuldades em decidir quais leis

\footnotetext{
$258 \quad$ Petersmann (2008), p. 379.

259 Ibid.

$260 \quad$ Ibid., p. 380 (“judicial protectionism”).

$261 \quad$ Vide Snyder (2003) e Griller (2000).

262 Tribunal de Justiça da União Europeia (Grande Secção), Processos apensos C-402/05 (Yassin Abdullah Kadi) e C-415/05 (Al Barakaat International Foundation), julgamento de 3 de setembro de 2008.

$263 \quad$ Vide De Búrca (2010).
} 
derrubar para garantir a conformidade da legislação nacional com as regras da $\mathrm{OMC}$, obrigando-o a questões complexas para os poderes políticos. ${ }^{264}$ Em termos práticos, a forma como operaria uma provisão de efeito direto seria obscura. Afinal, há diversas maneiras de cumprir uma decisão do OSC e mesmo painéis e o Órgão de Apelação relutam em sugerir uma forma de cumprimento; quando o fazem, limitam-se a observar que a remoção das medidas em questão seria uma das formas de cumprimento.

\section{Propostas de Reformas da Retaliação}

As propostas apresentadas acima fornecem instrumentos alternativos à retaliação comercial para produzir compliance. Uma segunda categoria de propostas visa a reformar a própria retaliação. Tais propostas partem, em regra, do princípio de que a retaliação comercial atende às necessidades do sistema multilateral de comércio na medida em que permite pressionar com medidas concretas o Membro violador. Incentivam o segmento da indústria local afetado negativamente a batalhar politicamente contra a violação percebida como função de pressões de segmentos da indústria beneficiados pela limitação da concorrência.

\section{a) Direitos de Retaliação Retroativos}

A prática do GATT e da OMC é a de estabelecer direitos de retaliação apenas após a tomada de decisão multilateral (no caso da OMC, após a passagem do prazo razoável de tempo), sem que esses direitos abarquem valor equivalente ao prejuízo sofrido desde o início da violação até a decisão multilateral. Essa prática foi reafirmada recentemente no caso EUA - Algodão, no qual os árbitros negaram ao Brasil o direito de retaliar em valor equivalente ao subsídio Step $2 .^{265}$

Essa prática contradiz as regras costumeiras do direito internacional geral em matéria de responsabilidade dos Estados. O Artigo 31 do Projeto CDI inclui entre as consequências de qualquer ato ilegal a obrigação de reparar totalmente o dano causado pelo ato ilícito. O Artigo 35 especifica que o Estado responsável tem a obrigação de pagar uma restituição, isto é, de restabelecer - desde que possível - o status quo ante. Além

\footnotetext{
$264 \quad$ Charnovitz (2001), p. 825.

265 Vide, neste trabalho, a parte II.D.11.
} 
disso, pelo Artigo 36, o Estado deve compensar quaisquer danos causados pelo ato ilegal que não tenham sido abarcados pela restituição. Esses artigos refletem o direito costumeiro, expresso pela Corte Permanente de Justiça Internacional (“CPJI') já em 1927 no Case Concerning the Factory at Chorzów. ${ }^{266}$

Combinando-se essa prescrição do direito internacional geral com a noção, hoje pacífica, de que os acordos da OMC - bem como as 'recomendações' de painéis e do Órgão de Apelação, após sua adoção pelo OSC - geram obrigações internacionais, pode-se deduzir uma obrigatoriedade de pagamento de reparação, restituição e compensação, em paralelo com a obrigação central de remover a medida ilegal. Há apoio para isso, ao menos no que se refere a subsídios, na decisão do Painel em Australia - Subsidies Provided to Producers and Exporters of Automotive Leather (“Austrália - Couro Automotivo") de que a recomendação de remover o subsídio "não [está] limitada a ações prospectivas mas pode incluir a devolução do subsídio proibido"267, uma decisão no mínimo inovadora.

Debra Steger argumenta que o "remédio prospectivo" da retaliação também falha em reparar completamente violações das regras de antidumping, salvaguardas e medidas compensatórias. Nesses casos, o remédio prospectivo não teria qualquer efetividade. ${ }^{268} \mathrm{~A}$ autora sugere a possibilidade de que a obrigação de respeitar os acordos da OMC deva por isso incluir a obrigação de reparar o prejuízo sofrido anteriormente à violação. Assim, a "remoção da medida" prevista pelo Artigo 3.7 do ESC, para ser efetiva, precisaria incluir a reversão de pagamentos anteriores. A autora lembra que os próprios painéis, bem como o Órgão de Apelação, já dispõem, nos termos do Artigo 19.1 do ESC, do poder de sugerir a maneira pela qual um membro violador pode implementar suas recomendações. Apesar de esse poder ter sido pouco utilizado, ele existe; portanto, um membro reclamante poderia solicitar dos painéis e do Órgão de Apelação esse esclarecimento. ${ }^{269}$

\footnotetext{
$266 \quad “(\ldots)$ it is a principle of international Law that the breach of an engagement involves an obligation to make reparation in an adequate form. Reparation therefore is the indispensible complement of a failure to apply a convention and there is no necessity for this to be stated in the convention itself." Case Concerning the Factory at Chrozów (Alemanha v. Polônia), decisão de 13 de setembro de 1928, 1929 PCIJ, Série A, no. 17 , p. 21.

267 A remoção "[is] not limited to prospective action only but may encompass repayment of the prohibited subsidy but may encompass repayment of the prohibited subsidy", Austrália - Couro Automotivo [WT/DS126/RW], adotado em 14 de fevereiro de 2000, 6.39 .

268 D. Steger (2008), p. 301.

269 Ibid., p. 306.
} 
Joel Trachtman propõe retaliação retroativa baseado em argumentos sobre os incentivos que pesam na decisão dos Membros. Segundo o autor, os Membros cumprirão as regras apenas se os benefícios do noncompliance forem menores que o valor das possíveis retaliações. Forte em sua linha Law and Economics, ele argumenta, entretanto, que o valor dessas retaliações deve estar sujeito a um acréscimo em razão (i) do tempo decorrido entre a ocorrência do dano e a efetivação das retaliações, além (ii) da incerteza associada ao enforcement. ${ }^{270}$ Propõe que a medida dos danos, além de prospectiva, seja também retrospectiva, acrescida de juros e aumentada com um multiplicador para refletir tanto a incerteza do enforcement como o custo sofrido pelo aplicador das retaliações.

Goh e Ziegler manifestam-se contra a decisão do painel em Austrália - Couro Automotivo. Argumentam que, além de ultra petita, a decisão colide com o objeto e fim do Acordo da $\mathrm{OMC}$, uma vez que "[t]he multilateral trading system is about a balance of rights and obligations with the WTO to preserve future trading opportunities rather than redress past injury". ${ }^{271}$ Lembram também as dificuldades práticas da obrigação de reembolso, como a inconstitucionalidade em diversos sistemas jurídicos de o governo desapropriar bens de particulares sem base em lei anterior e sem compensação, e os problemas que poderiam advir de retaliações aplicadas contra um noncompliance eterno fundado no não-reembolso de um subsídio pago cinco, dez ou cinquenta anos antes. ${ }^{272}$

Alan Wolff critica a proposta sobretudo em virtude do preenchimento de lacunas ("gap-filling") por painéis, que resultaria em punição por uma medida que, quando tomada e antes de declarada ilegal, era legítima. ${ }^{273}$ Busca apoio no Artigo 28 da Convenção de Viena sobre Direito dos Tratados (“Convenção de Viena"), o qual postula a nãoretroatividade dos tratados. ${ }^{274}$ Invoca em seguida a presunção de cumprimento até demonstração em contrário. ${ }^{275}$ Mais apropriadamente, poderia invocar a presunção geral de boa-fé dos Estados que vigora no direito internacional. 


\section{b) Retaliação Mais-Que-Proporcional}

Uma retaliação mais-que-proporcional produziria presumivelmente maior incentivo ao compliance: de um ponto de vista puramente mercantilista, daria ao Membro retaliante mais "vantagens" do que a retaliação meramente equivalente, permitindo-lhe sobretaxar a importação de mais produtos do Membro violador. Talvez a Jamaica tenha levado esses fatores em consideração ao propor que uma "implementação" do Artigo 21.8 do ESC se leve em conta, para países em desenvolvimento, não apenas o valor de comércio afetado mas também o impacto na economia dos países em desenvolvimento afetados. ${ }^{276}$

$\mathrm{Na}$ doutrina, Trachtman considera que a retaliação meramente equivalente é insuficiente para produzir o compliance. Compara a retaliação meramente equivalente a uma lei contra o furto que simplesmente obrigasse o ladrão a devolver a propriedade furtada quando descoberto. ${ }^{277}$ Por essa razão, defende uma ampliação do valor da retaliação, para igualar a retaliação não ao dano causado mas ao benefício auferido pelo violador - incluindo para isso danos retroativos e juros, além de um multiplicador para compensar, nos cálculos do violador a incerteza da aplicação de medidas de enforcement.

Alan Wolff critica essa possibilidade, lembrando que, apesar de toda a complexidade de cálculos realizados, há pouca base racional na ideia de que um determinado nível de retaliações seja "equivalente" a um determinado nível de danos, ${ }^{278}$ tese defendida de maneira convincente também por Spamann. ${ }^{279}$ Wolff é contra adicionar à mistura "entirely subjective additional factors" como os objetivos de desenvolvimento - e, presumivelmente, um "multiplicador de incerteza" -, o que serviria apenas para "further discredit the existing system". ${ }^{280}$

Atuando a partir das premissas de que pode haver violações eficientes dos acordos e de que é desejável que haja espaço para estas, alguns autores observam que o sistema atual não desencoraja suficientemente as violações ineficientes. Isso porque a obrigação de que a retaliação seja proporcional ao dano causado não permite ao Membro atingido

\footnotetext{
276 "Contribution by Jamaica to the Doha Mandated Review of the Dispute Settlement Understanding (DSU)", comunicado da Jamaica [TN/DS/W/21], 10 de outubro de 2002, p. 3.

277 Trachtman (2007), p. 141.

278 Wolff (2008), p. 806.

279 Spamann (2006)

280 Wolff (2008), p. 806.
} 
restabelecer o seu nível de bem-estar: ao restabelecer a relação comercial com base em novas e mais altas tarifas, os dois lados perdem volume de comércio, de forma que o Membro retaliante perde bem-estar.

Kyle Bagwell, partindo da teoria dos termos de troca, sugere que isso pode ser evitado por meio de uma autorização para retaliações mais-que-proporcionais no caso de violações graves dos acordos. Armado dessa possibilidade, o Membro retaliante supondo-se que tenha poder econômico - aumentaria tarifas até que houvesse uma alteração dos termos de troca em seu benefício. O governo retaliante seria então compensado pela redução do volume de comércio; reflexamente, o retaliado veria prejudicados os seus termos de troca. Essa possibilidade, segundo Bagwell, desincentivaria em teoria violações ineficientes e garantiria que as violações fossem mantidas apenas se globalmente eficientes. ${ }^{281}$

Bagwell, entretanto, observa que esse aprimoramento, funcional em teoria, enfrenta enormes dificuldades de aplicação prática. Em primeiro lugar, haveria dificuldade de aplicar esse modelo a um sistema multilateral, já que retaliações mais-que-proporcionais colidem com o princípio da reciprocidade e podem gerar para terceiros Membros externalidades, positivas e negativas, difíceis de prever. ${ }^{282} \mathrm{Em}$ segundo lugar, pela quase impossibilidade para os árbitros de calcular um valor para essas retaliações mais-queproporcionais. Além do já complicado cálculo dos efeitos da violação sobre o comércio, os árbitros teriam de compreender como as mudanças de volume de comércio interagem com as pressões políticas e custos de ajuste econômico no Membro retaliante, para poderem traduzi-las em prejuízo adicional a ser computado no valor da retaliação. ${ }^{283}$

Hudec afirma que essa "retaliação punitiva" provavelmente seria contraprodutiva como forma de assegurar a remoção da medida violadora. Ainda que pudesse agradar aos setores prejudicados pela medida em questão, acabaria sendo mais danosa à economia do Membro retaliante do que uma medida meramente proporcional, além de aumentar a resistência interna à suspensão da retaliação uma vez atingido o compliance. ${ }^{284}$ Jide Nzelibe vai no mesmo sentido, lembrando que retaliações mais-que-equivalentes dentro de

\begin{tabular}{ll}
\hline 281 & Bagwell (2008), pp. 748-749. \\
282 & Ibid., pp. 749-750. \\
283 & Ibid., p. 750. \\
284 & Hudec (2000), [p. 26].
\end{tabular}


um mecanismo de self-help são altamente suscetíveis de deteriorarem em uma "free for all escalation in which all parties will be made worse off". ${ }^{285}$

\section{c) Reforço da Retaliação Cruzada}

Em comunicação feita pela Índia em nome de Cuba, República Dominicana, Egito, Honduras, Jamaica e Malásia, é proposta a criação de um Artigo 22.3bis no ESC, permitindo a um Membro país em desenvolvimento como demandante em uma disputa com um Membro país desenvolvido ter sempre recurso à retaliação cruzada, ou seja, a aplicação de contramedidas em outros acordos além daquele objeto da disputa. ${ }^{286}$

Essa proposta parece ter um objetivo claro: permitir aos Membros em desenvolvimento retaliar contra Membros desenvolvidos suspendendo direitos de propriedade intelectual. O fundamento presumível é a dificuldade enfrentada pelos países em desenvolvimento de retaliar por meio do aumento de tarifas, o qual produz poucos efeitos comerciais danosos para o Membro retaliado, podendo entretanto prejudicar fortemente a economia do Membro em desenvolvimento retaliante. Nesse sentido, buscase facilitar a retaliação em propriedade intelectual, área sensível às indústrias farmacêutica, de alta tecnologia e do entretenimento, usualmente localizadas nos países desenvolvidos. Adicionalmente, argumenta-se que essa suspensão de concessões ou de outras obrigações não apresenta efeitos econômicos adversos, tendo inclusive potencial para aumentar o bem-estar do Membro retaliante, ao permitir à sua indústria fabricar produtos "genéricos" sem pagar preço monopolista ao detentor de patente ou direito de autor.

Henning Grosse Ruse-Kahn argumenta que, se corretamente aplicada, a suspensão de direitos de propriedade intelectual pode ser benéfica ao bem-estar do Membro retaliante. ${ }^{287}$ Bem utilizada, uma retaliação como essa pode trazer benefícios nos setores de saúde e educação, além de auxiliar no desenvolvimento de uma indústria de alta

\footnotetext{
$285 \quad$ Nzelibe (2008), p. 329.

286 "Notwithstanding the principles and procedures contained in paragraph 3, in a dispute involving a developing country Member as complaining party and a developed country Member as a party complained against, the complaining party shall have the right to seek authorization for suspension of concessions or other obligations with respect to any or all sectors under any covered agreements, if the party complained against fails to bring its measures into compliance with the rulings and recommendations of the DSB or a covered agreement." "Dispute Settlement Understanding Proposals: Legal Text", comunicado da Índia, [TN/DS/W/47], 7 de fevereiro de 2003.

287 Grosse Ruse-Kahn (2008), pp. 335-339.
} 
tecnologia. Adicionalmente, o uso dessa retaliação poderia gerar no Membro violador pressões para o compliance que de outra forma Membros pequenos não poderiam produzir. Entretanto, lembra o autor, os menores países ainda terão dificuldades de aplicar retaliações realmente efetivas. Segundo Grosse Ruse-Khan, a retaliação em TRIPS não é suficiente para desfazer a assimetria entre os pequenos e os grandes mercados: os maiores Membros (tanto desenvolvidos quanto em desenvolvimento), diz, teriam pouco interesse em participar do sistema se este anulasse as assimetrias de poder existentes. ${ }^{288}$

\section{d) Direitos de Retaliação Negociáveis}

A possibilidade de tornar os direitos de retaliação negociáveis se baseia numa proposta feita pelo México em 2002, fundada na dificuldade que podem ter os Membros menores em encontrar um setor no qual a retaliação possa ser efetiva:

"The suspension of concessions phase poses a practical problem for the Member seeking to apply such suspension. That Member may not be able to find a trade sector or agreement in respect of which the suspension of concessions would bring about compliance without affecting its own interests...There may be other Members, however, with the capacity to effectively suspend concessions to the infringing Member." 289

Assim, o México propõe que seja permitido ao Membro prejudicado, além de retaliar em valor equivalente, transmitir a outros Membros (possivelmente de forma onerosa) o direito de realizar essa retaliação. Segundo o próprio México, os benefícios que poderiam advir dessa permissão seriam, de um lado, tornar mais realista para o Membro violador a possibilidade de retaliação, o que incentivaria o compliance ${ }^{290}$ de outro, proporcionar ao Membro afetado um benefício tangível em troca de seu direito de suspender concessões, produzindo um "melhor reajuste das concessões". ${ }^{291}$

Bagwell, Mavroidis e Staiger realizaram um estudo econômico da proposta. ${ }^{292}$ Sua conclusão é que pode haver interesse de terceiros países em adquirir esse direito de retaliação, tanto pela possibilidade de pressionar pelo compliance quanto pelas pressões

\footnotetext{
$288 \quad$ Ibid., p. 363.

289 "WTO Dispute Settlement Understanding, Negotiations on Improvements and Clarifications of the Dispute Settlement Understanding" proposta do Mexico [TN/DS/W/23], 4 de novembro de 2002, p. 5.

$290 \quad$ Ibid., p. 6.

291 Ibid.

292 Bagwell, Mavroidis e Staiger (2003).
} 
internas que pode haver para proteção de um mercado. Observam que, se for permitido ao Membro violador participar do leilão - e assim "comprar" do Membro prejudicado o direito de retaliação - há boas chances de o leilão ser bem-sucedido, pois enquanto terceiros Membros enfrentam incerteza sobre os efeitos econômicos que a retaliação teria, o Membro violador sofre necessariamente todo o impacto econômico de essa retaliação ser exercida.

Em artigo posterior, Bagwell ${ }^{293}$ considera a crítica segundo a qual esse sistema de compra de direitos de retaliação não funcionaria, tendo em vista que os governos não pagariam pelo direito de se prejudicarem. Conforme sua teoria, contudo, governos de grandes economias, capazes de influenciar os termos de troca, poderiam se beneficiar do direito de aumentar unilateralmente tarifas negociadas num nível mais baixo que o nível ótimo. Retomando o estudo feito anteriormente, aponta que leilões de que participe o Membro violador têm grandes chances de terminar com uma vitória deste, que aceitaria pagar para "remover do mercado" o direito de outros Membros exercerem a retaliação.

Bagwell aponta que essa possibilidade equivaleria, na prática, a uma compensação "forçada" do Membro violador ao prejudicado, ou seja, seria uma forma de implementar a compensação obrigatória. ${ }^{294} \mathrm{O}$ autor, entretanto, ressalva que há riscos no uso desse mecanismo, como provocar um uso excessivo do sistema de solução de controvérsias e possivelmente transformar tensões comerciais inicialmente bilaterais em tensões multilaterais. $^{295}$

Jide Nzelibe faz uma objeção mais fundamental à proposta de retaliação por terceiros. Segundo o autor, os altos custos e o prolongado tempo de uma disputa na OMC tornam essa alternativa desinteressante para qualquer interesse protecionista, que teria de esperar dois ou três anos para impor barreiras. ${ }^{296}$ Simultaneamente, a existência de um grupo dentro do Membro reclamante interessado no efetivo compliance produz incentivos para uma retaliação de enforcement. Caso terceiros Membros possam adquirir os direitos de retaliação, entretanto, o único incentivo interno que possuem para isso é o dos grupos protecionistas domésticos - que passam a contar com uma alternativa legal, relativamente

\begin{tabular}{ll}
\hline 293 & Bagwell (2008). \\
294 & Ibid. \\
295 & Ibid. \\
296 & Nzelibe (2008), p. 335.
\end{tabular}


barata e imediatamente disponível para impor barreiras a seus competidores. Uma retaliação aplicada por terceiros Membros, portanto, tenderia a ser guiada por esses interesses, e não pelo objetivo de enforcement. ${ }^{297}$ 


\section{O SISTEMA DE RETALIAÇÃO COLETIVA}

A retaliação coletiva foi proposta por uma série de países em desenvolvimento no âmbito das negociações de reforma do ESC. Conforme aponta Hudec, essa ideia constava já da proposta de reforma da solução de controvérsias do GATT apresentada em 1966 por Brasil e Argentina, países em desenvolvimento, quando foi bloqueada pelos países desenvolvidos. $^{298}$

Em 1977, a proposta para introdução de retaliação coletiva foi novamente apresentada pelo Brasil, por meio do então chamado "Brazilian Framework proposals”, a qual todavia também não ganhou apoio. Conforme apontou Hudec, "Brazil's 1977 proposals sought to reintroduce some of the additional demands that had been rejected in 1966 - chiefly, a more active, prosecutorial role for the GATT Secretariat, and stronger remedies for developing country complaints, such as collective retaliation or money damages". 299

Conforme o comentário lúcido de Robert Hudec, “[d]eveloped countries, viewing things from the perspective of their role as potential defendants, are quite comfortable with membership in a legal system where they can hurt others but some others cannot really hurt them". ${ }^{300}$ Ao assim descrever a questão, Hudec parece identificar um problema de desequilíbrio de poder no âmbito do SSC/OMC.

Dentro da OMC, em 2002, a proposta surgiu primeiramente na forma de uma pouco definida "large-scale retaliation" proposta pelo Equador como consequência do nãooferecimento de compensações por um Membro violador. ${ }^{301}$ Também em 2002, o grupo dos Países Menos Desenvolvidos ("PMDs") propôs a adoção de um "princípio de responsabilidade coletiva" como o equivalente na Carta da ONU. Esse princípio daria a todos os Membros o direito e a responsabilidade de sancionar o não-cumprimento de uma recomendação do OSC. $^{302}$ No caso de o Membro prejudicado ser um país em

\footnotetext{
298 Hudec (2000), p. 26. Vide também nota de rodapé 223 acima e texto que a acompanha.

$299 \quad$ Hudec (1993), p. 42.

$300 \quad$ Ibid., p. 27.

301 "Contribution of Ecuador to the Improvement of the Dispute Settlement Understanding of the WTO", comunicado do Equador [TN/DS/W/9] 8 de julho de 2002, p. 5.

302 "Negotiations on the Dispute Settlement Understanding", proposta do grupo dos PMDs, TN/DS/W/17, 9 de outubro de 2002, p. 4.
} 
desenvolvimento ou país menos desenvolvido, essa retaliação coletiva seria automática, e sua adoção pelo OSC não deveria ser limitada pela anulação ou prejuízo. ${ }^{303} \mathrm{Na}$ proposta de emenda formalizada, apenas os PMDs seriam beneficiados pela retaliação coletiva.

Essa proposta foi em seguida (22 de janeiro 2003) formalizada pelo mesmo grupo, mas garantindo a retaliação coletiva apenas para os PMDs. ${ }^{304}$ Em seguida (24 de janeiro de 2003), o Grupo Africano propôs emenda ao ESC estendendo a retaliação coletiva para os países em desenvolvimento. ${ }^{305}$ As propostas divergem em relação ao nível de retaliações autorizado. Para os PMDs, o nível de anulação ou prejuízo sofrido pelo PMD prejudicado deveria ser usado como base, permitindo a cada Membro utilizar a totalidade dessa anulação ou prejuízo para sua própria retaliação. ${ }^{306} \mathrm{O}$ Grupo Africano sugeriu uma fórmula mais flexível, que assegurasse compensação plena ao prejudicado, a proteção de seus interesses de desenvolvimento e a efetiva implementação das recomendações e decisões do OSC. ${ }^{307}$

Vários autores têm identificado na retaliação coletiva uma alternativa para se aprimorar o sistema de enforcement do SSC/OMC (no sentido de induce compliance). Como abordou Alberto do Amaral Jr., ao comentar a proposta do Grupo Africano, o instrumento da retaliação coletiva "se resumiria na possibilidade, reservada a mais de um membro, de suspender concessões, sempre que esta faculdade fosse expressamente reconhecida a um país [em desenvolvimento] vitorioso em uma disputa contra algum país [desenvolvido], mudança que equivaleria à passagem de um sistema bilateral para outro de natureza multilateral". ${ }^{308}$ Acrescenta Amaral Jr. que "[a]credita-se que a retaliação coletiva compensaria a debilidade econômica e política de certos Estados e seria de grande utilidade para instaurar maior equilíbrio entre os contendores". ${ }^{309}$ Ao assim fazer, Amaral Jr. parece indicar que a raiz do problema de enforcement seja o "desequilíbrio de poder", sendo a retaliação coletiva uma potencial solução para tal questão.

\footnotetext{
$303 \quad$ Ibid.

304 "Text for LDC Proposal on Dispute Settlement Understanding Negotiations", comunicado do Haiti [TN/DS/W/37], 22 de janeiro de 2003, p. 3.

305 "Text for the African Group Proposals on Dispute Settlement Understanding Negotiations", comunicado do Quênia [TN/DS/W/42], 24 de janeiro de 2003, p. 4.

$306 \quad \mathrm{TN} / \mathrm{DS} / \mathrm{W} / 37,22$ de janeiro de 2003, p. 3.

307 TN/DS/W/42, 24 de janeiro de 2003, p. 4.

$308 \quad$ Amaral Jr. (2008), p. 114.

309 Ibid., p. 114.
} 
Como indicado anteriormente, embora não tenha se detido sobre o assunto, Robert Hudec identificou na implementação de um sistema de retaliação coletiva como um meio eficaz para assegurar a obediência pelos Membros das obrigações oriundas do Acordo da $O M C$.

Já Giovanni Maggi, por meio de estudos com teoria dos jogos, propõe o estabelecimento de um mecanismo de enforcement multilateral para a OMC. ${ }^{310}$ Maggi parte do tradicional modelo do dilema do prisioneiro: nesse modelo, a OMC promove a cooperação ao permitir monitoramento bilateral das condutas e reação dos Membros imediatamente afetados. O autor acrescenta a esse modelo o fato de que a natureza multilateral da OMC permite um monitoramento coletivo, e que o modelo tradicional não leva em conta a possibilidade de enforcement por terceiros. Argumenta que essa possibilidade já existe, ainda que por meios externos às regras da $\mathrm{OMC}$, e se reflete na perda de reputação do Membro violador, a qual leva terceiros Membros a reagir negativamente em relação ao violador. ${ }^{311}$

Aplicando seu modelo ao sistema multilateral de comércio, Maggi conclui que um modelo de relacionamentos e enforcement bilateral é incapaz de manter uma estrutura de livre comércio, visto que um Membro A pode individualmente aumentar suas tarifas em relação a um Membro B sobre o qual A tenha poder econômico - isto é, B depende do Membro A descumpridor para adquirir suas exportações, sem que o inverso seja verdadeiro. ${ }^{312}$ Nesse cenário, B não tem meios de retaliar de maneira eficaz, e, se o fizer, arrisca uma contrarretaliação de A. Num modelo de enforcement multilateral, entretanto, um Membro A que descumpra obrigações com relação ao Membro B (dependente de A) está ainda sujeito a retaliação por um terceiro Membro $\mathrm{C}$, menos sujeito ao poder econômico de A. ${ }^{313}$ Os custos de aplicar o enforcement multilateral são então repartidos entre todos os Membros ${ }^{314}$ - no caso da OMC atualmente, 153 Membros. A potencialidade de uma perda de reputação vis-à-vis todos os Membros da organização é o que, segundo Maggi, explica o fato de grandes potências alterarem sua conduta quando condenadas em painéis do GATT e da OMC, mesmo em casos contra pequenos países.

\begin{tabular}{ll}
\hline 310 & Maggi (1999). \\
311 & Ibid., p. 191. \\
312 & Ibid., p. 199. \\
313 & Ibid. \\
314 & Ibid., p. 203.
\end{tabular}


Nesse sentido, a proposta de retaliação coletiva seria uma mera institucionalização da sanção coletiva (pela perda de reputação) que atualmente ocorre de forma informal.

Joost Pauwelyn identifica no compliance com as regras da OMC um bem coletivo. $^{315}$ Essa possibilidade, entretanto, é pouco explorada nas regras atuais, que permitem na prática que dois Membros concordem em "compensar-se", permitindo-se mutuamente adotar conduta incompatível com as regras da organização. ${ }^{316}$ Essas mesmas regras, ao impossibilitar a retaliação coletiva, concentram no Membro vencedor todos os custos da retaliação econômica. Com isso, Membros mais fracos ficam especialmente prejudicados, quando poderiam ter no enforcement coletivo um remédio jurídico efetivo. ${ }^{317}$ Embora Pauwelyn defenda que as obrigações derivadas do Acordo da OMC sejam de natureza bilateral - não multilateral -, o próprio Pauwelyn indica que tal circunstância não impediria a adoção de um mecanismo multilateral, o qual não modificaria a natureza jurídica das obrigações oriundas do Acordo da OMC, in verbis:

"At the same time, although WTO obligations are reciprocal in nature, nothing prevents WTO members from setting up a collective noncompliance mechanism (...). Such a collective non-compliance mechanism would not alter the character of WTO obligations and somehow transform them into integral obligations simply because they are enforced collectively (...). The efficient implementation of WTO rules may, indeed, be well (if not better) served by a collective compliance mechanism, instead of the current bilateral, state-to-state litigation system centered around breach and bilateral countermeasures. "318

Ainda há que se mencionar os comentários de Petros Mavroidis, o qual observa que, para exercerem a função de levar os Membros violadores ao compliance, as contramedidas da OMC devem impor a estes custos mais altos do que o benefício produzido pela violação. ${ }^{319}$ Dada a disparidade de poder de mercado dos Membros, nem todos possuem a capacidade econômica de aplicar contramedidas efetivas. Embora saúde a então recente decisão dos árbitros de permitir ao Equador retaliar suspendendo direitos de propriedade intelectual, considera "highly unlikely that the European Community will change its banana-import regime because of the Ecuadorian countermeasures in 
TRIPs". ${ }^{320}$ Quanto ao argumento gerencialista segundo o qual a interação repetida e a reputação em risco são suficientes para produzir o compliance, Mavroidis considera-o insuficiente: além de todas as razões subjetivas para o cumprimento das regras, a segurança jurídica exige uma razão institucional, a qual deve fazer parte do contrato para assegurar o respeito às normas em todas as ocasiões. ${ }^{321}$ Embora não proponha diretamente alguma alteração, Mavroidis observa que falhas de duas ordens impedem um maior respeito às regras: de um lado, a ausência de um órgão supranacional de controle do cumprimento dos acordos; de outro, a dificuldade dos países em desenvolvimento em aplicar contramedidas efetivas. Considera por isso necessário discutir a reforma do sistema de remédios para non-compliance dentro do quadro multilateral. ${ }^{322}$

Bagwell, Mavroidis e Staiger avaliam uma proposta mexicana para a reforma do ESC: a possibilidade de implementar a multilateralização do mecanismo de retaliação por meio de leilões, nos quais Membros detentores de "direitos de retaliação" pudessem vendêlos a terceiros Membros, que então aplicariam eles a retaliação. ${ }^{323}$ Por meio de análises econômicas, concluem que esses leilões tendem a ser bem-sucedidos, especialmente se for permitido ao Membro violador "recomprar" o direito de retaliar contra si próprio essencialmente, oferecendo compensação ao Membro prejudicado. ${ }^{324}$ Isso porque, desde que haja outros Membros que possam oferecer ameaça real de retaliação, o Membro prejudicado tem consciência que sofrerá os custos da retaliação na sua integralidade. Preferirá por isso compensar o Membro prejudicado.

$\mathrm{O}$ amadurecimento do $\mathrm{SSC} / \mathrm{OMC}$ rumo à implementação de uma retaliação coletiva foi objeto de estudo anterior do candidato, o qual buscou identificar elementos no desenvolvimento de tal sistema para justificá-la, sem ter todavia apresentado sugestões efetivas acerca de sua solução ou implementação. Recorrendo à análise hartiana do direito, atribuiu-se parte dos problemas atuais à falta de um "centro de poder" capaz de nivelar a disputa entre os Membros de níveis econômicos díspares. ${ }^{325}$ Naquela oportunidade, lembrou-se que, na teoria das relações internacionais, a cooperação depende da existência de interesses recíprocos, da projeção de interações futuras entre os jogadores e do número

\footnotetext{
$320 \quad$ Ibid., p. 808.

321 Ibid., p. 811

322 Ibid.

323 Bagwell, Mavroidis e Staiger (2003).

$324 \quad$ Ibid., p. 37.

$325 \quad$ Medrado (2004), p. 334
} 
de jogadores. ${ }^{326}$ Embora o regime do GATT permitisse a troca de informações e a economia de custos de transação, foi necessário legalizar o regime para superar problemas na estrutura normativa; a falta de clareza por um lado, e a falta de enforcement por outro, permitiam ações oportunistas de non-compliance. ${ }^{327}$ Algumas dessas ações permanecem possíveis na $\mathrm{OMC}$, em parte pela falta de enforcement multilateral, já aparentemente necessário dada a mudança sofrida pelo regime internacional de comércio multilateral, com a incorporação de regramentos de integração positiva, como TRIPS, SPS, TBT, entre outros, deixando de ser um regime de integração negativa somente. $\mathrm{O}$ argumento de que a mera troca de informações permitiria maior compliance, porém, parece se aplicar com dificuldade ao regime da OMC, que não envolve apenas a coordenação de ações para um objetivo maior mas requer cooperação num cenário em que há incentivos econômicos para a violação. $^{328}$

Naquela oportunidade, abordou-se, ainda, que uma das características atrativas do sistema de retaliação coletiva reside na possibilidade de mudança da distribuição de payoffs, com base em que o Membro demandado toma decisão de implementar ou não a recomendação do OSC. Isso porque a característica de bilateralidade nas contramedidas, da forma como estruturadas atualmente, pode sofrer um efeito de saturação - ou seja, a partir de um determinado ponto no nível da sanção, o Membro demandado poderá ficar indiferente ao efeito da retaliação bilateral, sendo qualquer aumento (mesmo "mais-queproporcional" ou "punitivo") ineficaz para provocar uma mudança, sem mencionar a possibilidade de ferir a devida proporcionalidade requerida pelo ESC e pelo Projeto CDI. Ou seja, a partir de um determinado ponto, a retaliação bilateral pode ser simplesmente insuficiente ou ineficaz.

Resolvendo a questão da saturação da retaliação bilateral, a entrada de outros players ou interesses na análise do Membro demandado pode contribuir para modificar a estrutura de payoffs e, por conseguinte, influenciar positivamente a tomada de decisões por parte do Membro demandado. Retomando Maggi, teceu-se os seguintes comentários a 
respeito, que embasam a proposição de que a retaliação coletiva constitui uma alternativa que incrementa a eficácia do sistema de enforcement do SSC/OMC: ${ }^{329}$

"Although favoring the adoption of MEMs [multilateral enforcement mechanisms], Maggi does not propose the total elimination of BEMs [bilateral enforcement mechanisms]. Instead, Maggi suggests that the two mechanisms should be coupled and applied jointly. Thus, a defecting player would face three constraints in case of defection: two BEMs (seeking to deter defection against the player imposing the BEM) and one MEM (aiming to deter defection simultaneously against both players). [nota de rodapé omitida] BEMs would always be applied fully (in terms of duration) and maximally (in terms os severity). The level of the MEMs, on the other hand, would vary. Maintaining flexibility of third party sanctions reduces the incentives for the defecting party to defect simultaneously against the other two players (the two sides of the coin). [nota de rodapé omitida] On the other hand, raising BEMs up to the level beyond the indifference curve of the defecting player is innefective in terms of compliance because, beyond the indifference curve, the decision to defect controls, regardless of how high the level of the BEMs is set. [nota de rodape omitida] Therefore, the addition of MEM can shift the indifference curve of the defecting player, in terms of losses incurred with the other trading partner(s)."

Ainda, observando a proposta mexicana, defendeu-se a necessidade de um mecanismo multilateral de retaliações, mas identificou na proposta do "leilão" de direitos de retaliação alguns problemas. Em primeiro lugar, que seria necessário um mecanismo de legitimação do nível e tipo das sanções aplicadas - talvez com nova arbitragem para determinar em que acordos e setores o Membro adquirente pode exercer a retaliação. ${ }^{330}$ Em segundo lugar, após o leilão há o risco de o Membro que adquire os direitos de retaliação poder ser "compensado" pelo violador de maneira a distorcer o comércio internacional, o que seria prejudicial às regras multilaterais. ${ }^{331}$ Pelos mesmos motivos, propôs-se não se permitir ao Membro violador "recomprar" os direitos de retaliação contra si próprio - seria o mesmo que reintroduzir no sistema a possibilidade de pagamento pelo non-compliance. ${ }^{332}$

A possibilidade de retaliação coletiva foi recentemente objeto de comentários de outros autores, alguns deles negativamente. O Legal Affairs Officer da OMC, Reto Malacrida, identifica nessa proposta o objetivo de baixar o custo econômico da retaliação

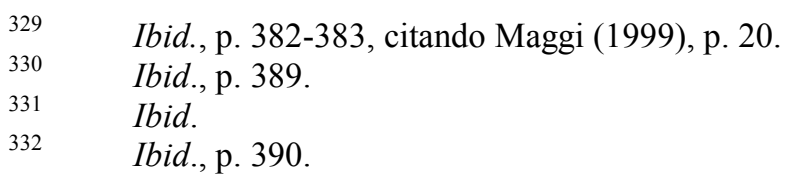


para os países em desenvolvimento, criando para estes uma possibilidade de enforcement em situações nas quais lhes seria impossível atuar individualmente, dados os custos associados com a retaliação individual. ${ }^{333}$ Identifica, entretanto, alguns problemas na proposta. Em primeiro lugar, as dificuldades da ação coletiva, já que é preciso que o Membro país em desenvolvimento prejudicado convença outros Membros a sofrer o custo de uma retaliação ${ }^{334}$ - o qual tende a se tornar elevado conforme as retaliações coletivas forem se acumulando. Há também as dificuldades de aprovar essa proposta, dada a obscuridade sobre a alocação dos custos entre os Membros retaliantes: seria esta negociada caso a caso ou haveria uma fórmula? Finalmente, Malacrida identifica uma dificuldade de coordenação: ou bem cada Membro decidiria por si em que acordos e setores retaliar, criando o risco de retaliação aleatória e desfocada, ou bem essa decisão deveria ser confiada a um sub-grupo de Membros retaliantes. ${ }^{335}$

Alan Wolff considera que a dificuldade essencial da retaliação coletiva é que ela espalha a controvérsia aos demais Membros da $\mathrm{OMC}$, com consequências imprevisíveis, que compara com a sequência de fatos que levaram à Primeira Guerra Mundial. ${ }^{336}$ Ainda que considere compreensíveis as motivações dos países em desenvolvimento proponentes, questiona se o resultado seria um sistema de comércio mais aberto -- em especial no caso de o Membro violador considerar injusta a condenação da medida. ${ }^{337}$

Jide Nzelibe faz à retaliação coletiva a mesma crítica que faz aos direitos de retaliação negociáveis, argumentando que esse tipo de retaliação tenderia a ser dirigido por interesses protecionistas. O resultado seria uma retaliação que, em vez de afetar grupos de exportadores politicamente salientes no Membro violador, atingiria grupos que exportam competitivamente para o terceiro aplicador da retaliação. ${ }^{338}$ Em vez de impor tarifas proibitivas num grupo focado, os interesses protecionistas usariam o direito recebido ou adquirido para impor tarifas suficientes apenas para deslocar produtos exportados.

\footnotetext{
$333 \quad$ Malacrida (2008), pp. 21-22.

334 Ibid., p. 22. Trata-se aqui do custo econômico: o aumento tarifário obriga importadores a procurar outra fonte do mesmo produto, as quais por terem sido até então preteridas se podem presumir mais caras ou de menor qualidade.

$335 \quad$ Ibid.

336 Wolff (2008), p. 812.

$337 \quad$ Ibid.

$338 \quad$ Nzelibe (2008), p. 337.
} 
Segundo o autor, é improvável que as estratégias dos dois grupos (protecionistas e atingidos pela violação) coincidam. ${ }^{339}$

Finalmente, há o argumento de que a falta de possibilidade de retaliação não é a causa mais importante para a assimetria entre os países usuários e os não-usuários do mecanismo de solução de controvérsias. Roderick Abbott observa que as próprias obrigações às quais os países menos desenvolvidos estão sujeitos são relativamente poucas e leves; por outro lado, seus privilégios comerciais são essencialmente tarifas preferenciais, que não são vinculantes dentro da OMC. ${ }^{340}$ Para o autor, uma litigância contra um Membro desenvolvido poderia provocar uma retaliação na forma de suspensão desses benefícios, que o Membro em desenvolvimento não teria como cobrar juridicamente dentro da organização. $^{341}$

A essa crítica se pode acrescentar a objeção baseada em trabalho de Nuno Limão e Kamal Saggi. ${ }^{342}$ Segundo os autores, há uma dificuldade quando pequenos países (em termos econômicos) tentam negociar preferências comerciais com um grande país, num modelo de self-help. Os países pequenos só poderão compelir o país grande se forem capazes de ameaçar com uma retaliação conjunta. Entretanto, a ameaça pode não ser crível, já que nenhum dos países pequenos tem um incentivo individual para punir desvios praticados pelo país grande. ${ }^{343}$ Isso porque, retomando a teoria dos termos de troca, apenas países com poder no mercado global têm capacidade de influir no preço global de um bem - países sem esse poder produzem danos para si mesmos sem danificar o oponente. ${ }^{344}$

Vale dizer que o Presidente do OSC, em junho de 2003, resolveu não incluir a proposta de retaliação coletiva no seu texto consolidado de modificações pretendidos ao ESC, datado de 16 de maio de 2003, pela ausência de um nível suficientemente elevado de suporte. $^{345}$ absence of a sufficiently high level of support, including, inter alia, accelerated procedures for certain disputes; improved panel selection procedures; increased Member-control on panel and Appellate Body reports; clarification of the treatment of amicus curiae briefs; certain proposed changes in the procedures for suspension of concessions or other obligations, including collective retaliation or enhanced surveillance
} 
A questão que se põe acerca da retaliação coletiva, portanto, parece ser como solucionar esse problema de ação coletiva, no qual os Membros fracos terminam não impondo a retaliação, seja porque temem contrarretaliação do Membro forte, seja porque têm expectativa de serem free riders na retaliação alheia, recebendo os benefícios do compliance sem arcar com os custos da sanção.

Nesse sentido, quer nos parecer que tal problema de ação coletiva na implementação de um sistema de retaliação coletiva pode ser examinado à luz da teoria de formação de alianças, a qual muito se desenvolveu no contexto da segurança internacional. Com efeito, a implementação de uma retaliação coletiva se perfaz justamente na formação de dois grupos: um grupo dos Membros que pretendem retaliar coletivamente o Membro violador; e outro grupo que preferirá se alinhar ao Membro violador (ou seja, manterá neutralidade, já que o Membro violador não poderá aplicar uma contraretaliação, uma vez que excluída tal possibilidade sem que haja a competente autorização pelo OSC). Ou seja, a pergunta básica de tal teoria é justamente verificar, dentro de determinada estrutura e condições, que países se alinharão com quais e em que condições e termos. A essa questão se dedicará o próximo capítulo, após o qual se retomará o debate acerca do SSC/OMC, então sob o ângulo da formação de alianças.

of the suspension of concessions or other obligations; and other proposals." (Relatório do Presidente, Embaixador Péter Balás, ao Comitê de Negociações Comerciais [WT/TN/DS/9]). 


\section{A TEORIA DE FORMAÇÃO DE ALIANÇAS}

\section{A. Introdução}

A teoria de formação de alianças tem por fundamento o conceito de equilíbrio de poder, ou balance of power, dentro da tradição realista.

Cumpre observar que a teoria de formação de alianças tem clara influência e desenvolvimento por teóricos realistas e neorrealistas, com especial ênfase em Hans J. Morgenthau, George Liska, Kenneth Waltz, Stephen Waltz e Glenn Snyder. Por conseguinte, esta tese se alinha ao arcabouço realista, não estando em seu escopo tecer considerações sistêmicas baseadas em outras matrizes teóricas referentes às relações internacionais.

Os elementos da teoria realista são conhecidos. Primeiramente, há que se ressaltar que a teoria realista não deve ser tomada como uma visão de mundo, mas como uma teoria que tenha apresentado uma metodologia de análise das relações internacionais, sem a pretensão de esgotar o exame das múltiplas facetas e variáveis envolvidas nas relações entre as nações. Todavia, ao se basear em elementos de caráter objetivo, a teoria realista (amplamente considerada) apresenta um ferramental que permite dissecar a relação entre determinadas unidades do sistema internacional, considerando sua estrutura e as capacidades de tais unidades.

Segundo a escola realista, os interesses dos atores/unidades determinam suas ações; as necessidades das unidades advêm da não regulada competição entre os estados (quando atores são constrangidos por força e competição, ao invés de autoridade e a lei); cálculos baseados em tais necessidades podem permitir descobrir as políticas que melhor servirão aos interesses das nações em questão; sucesso se perfará no teste final, e se definirá em termos de preservação ou fortalecimento do estado:

"The elements of Realpolitik, exhaustively listed, are these: The ruler's, and later the state's, interest provides the spring of action; the necessities of policy arise from the unregulated competition of states; calculation based on these necessities can discover the policies that will best serve a state's interests; success is the ultimate test of policy, and success is 
defined as preserving and strengthening the state. Ever since Machiavelli, interest and necessity - and raison d'état, the phrase that comprehends them-have remained the key concepts of Realpolitik. From Machiavelli through Meinecke and Morgenthau the elements of the approach and the reasoning remain constant. Machiavelli stands so clearly as the exponent of Realpolitik that one easlily slips into thinking that he developed the closely associated idea of balance of power as well. Although he did not, his conviction that politics can be explained in its own terms established the ground on which balance-of-power theory can be built." 346

Conforme expõe Robert O. Keohane, atenção é concentrada no comportamento dos estados, o qual se baseia em um pressuposto de racionalidade, em que cada unidade procura maximizar seus ganhos, dados determinados objetivos e à luz das informações disponível a cada ator no momento decisório:

"This research design is consistent with the hard core of Realism. Attention is concentrated on the behavior of states. In the initial statement of the problem, the rationality assumption, in suitably modest form, is retained: each actor attempts "to maximize expected value across a given set of consistently ordered objectives, given the information actually available to the actor or which he could reasonably acquire in the time available for decision." 347

Prosseguindo, Keohane ressalta a possibilidade de se buscar compreender a ação dos estados por meio da utilização de matrizes que, dada a racionalidade dos atores, permita calcular seus interesses, antecipando suas condutas: "[I]nterests are defined to a considerable extent in terms of power: that is, power factors are built into the game structure. (...) Faced with the game matrix, states, as rational actors, calculate their interests and act accordingly. The structure of world politics, as Waltz defines it, is reflected in the matrices and becomes the basis for action". ${ }^{348}$ Com efeito, a utilização de modelos que buscam compreender a ação das unidades no sistema internacional é uma constante, tendo se tornado praticamente corrente e estabelecida na análise das relações internacionais.

\begin{tabular}{ll}
\hline 346 & Waltz (2010), p. 117. \\
347 & Keohane (1986), p. 175 \\
348 & Ibid.
\end{tabular}


Forte nessas premisssas de poder, interesse e racionalidade é que a teoria de formação de alianças tem se desenvolvido, até porque, nos primórdios, foi impulsionada por um dos mais importantes teóricos realistas clássicos, Hans J. Morgenthau. ${ }^{349}$

\section{B. Autores Clássicos: Hans J. Morgenthau e George Liska}

Dentro do desenvolvimento evolutivo da teoria de formação de alianças, esta seção aborda os autores de linha clássica, entendidos como os autores que primeiramente buscaram elaborar uma sistematização de tal teoria, mediante especialmente a análise de observação de fatos históricos.

\section{Hans J. Morgenthau: O equilíbrio de poder e a formação de alianças}

Após discorrer sobre o poder das nações (seus elementos e formas de sua avaliação), o realista clássico Hans J. Morgenthau situa o equilíbrio de poder como um fator restritivo de tal poder nacional, na medida em que a detenção de diversos elementos de poder e de diferentes aspirações pelas nações soberanas as levam a adotar políticas ou estratégicas visando à manutenção ou à modificação do status quo (a chamada luta pelo poder ou pela paz, como consagrou Morgenthau). ${ }^{350}$

Com efeito, Morgenthau conceitua o equilíbrio de poder como sendo apenas uma manifestação particular de um princípio social geral característico de todas as sociedades compostas de unidades autônomas. ${ }^{351}$ Morgenthau acentua que a ideia de equilíbrio de poder (e as políticas visando sua preservação) não seria somente inevitável, mas sim um fator estabilizador essencial em uma sociedade de nações soberanas. Completa Morgenthau que a instabilidade do equilíbrio de poder internacional deriva não de uma falha do princípio em si, mas das condições particulares sob as quais o princípio opera, no âmbito da sociedade das nações soberanas. ${ }^{352}$ Nesse sentido, sobressai o papel de uma das

\footnotetext{
349 Ao lado de Morgenthau e Liska, como obra clássica, pode-se também fazer referência à obra de Robert L. Rothstein, que tratou da formação de alianças, com foco em nações pequenas (small powers). Os conceitos, desenvolvidos em Rothstein (1968), serão abordados oportunamente.

$350 \quad$ Morgenthau (2006), p. 179.

$351 \quad$ Ibid.

352 "It will be shown in the following pages that the international balance of power is only a particular manifestation of a general social principle to which all societies composed of a number of autonomous units owe the autonomy of their component parts; that the balance of power and policies aiming at its preservation are not only inevitable but are essential stabilizing factor in a society of sovereign nations; and that the
} 
principais condições particulares do sistema internacional de nações: a ausência de um poder central, caracterizando-o como uma anarquia.

Em sua clássica obra Politics Among Nations - The Struggle for Power and Peace, Morgenthau apresenta o equilíbrio de poder (balance of power) como um dos instrumentos utilizados ao longo dos séculos pelas nações soberanas para buscar aplacar as demais nações de conseguirem atingir suas aspirações, em especial quando se trate de aspirações conflitantes ou antagônicas. O corolário é o de que somente o poder consegue limitar o poder ("[Y] $]$ ou may cover whole skins of parchment with limitations, but power alone can limit power"). ${ }^{353}$

Adiante em sua obra, o então professor da Universidade de Chicago aborda o esgotamento de tal modelo para fins de segurança internacional, após lembrar do histórico e das facetas da política de equilíbrio de poder na Europa, dominante sobretudo naquele continente nos Séculos XVIII e XIX, ${ }^{354}$ mas cujo exaurimento levou aos dois conflitos mundiais do Século XX. Morgenthau passa então a desenvolver o que, já àquela época (1948, ano de publicação de sua obra), concluiu devesse ser o novo instrumental de restrição ao poder das nações: a adoção da moralidade, da ética e de normas, enfatizando, a partir daí, a criação no Século XX de instituições internacionais, com ênfase nas Nações Unidas, então fortalecida, comparativamente à Liga das Nações.

Não obstante, convém enfatizar que, para Morgenthau, o princípio da segurança coletiva não aboliu o sistema de equilíbrio de poder, mas somente o reafirmou na forma de uma aliança universal contra um potencial agressor, cuja premissa é que tal aliança universal sempre sobrepujará o agressor. ${ }^{355}$

instability of the balance of power is due not to the faultiness of the principle but to the particular conditions under which the principle must operate in a society of sovereign nations." (Ibid.)

$353 \quad$ Morgenthau (2006), p. 181 (citação de John Randolph).

354 "The Treaty of Utrecht of 1713, which terminated the War of Spanish Succession, recognized for the first time expressly the principle of the balance of Power by way of territorial compensations. It provided for the division of most of the Spanish possessions, European and colonial, between the Hapsburgs and the Bourbons 'ad conservandum in Europa equilibrium, ' as the treaty put it." (Morgenthau (2006), p. 191).

$355 \quad$ "Thus the period between the two world wars stands in fact under the sign of the balance of power by alliances and counteralliances, although in theory the principle of the balance of power was supposed to have been superseded by the League of Nations principle of collective security. Yet, actually, collective security, as will be shown later in greater detail, did not abolish the balance of power. Rather, it reaffirmed it in the form of a universal alliance against any potential aggressor, the presumption being that such an alliance would always outweigh the aggressor." (Morgenthau (2006), p. 204). 
Como bem enfatizou Christopher Bladen, posteriormente, ao comentar as obras de Morgenthau e George Liska, os dois sistemas (equilíbrio de poder e segurança coletiva) se baseiam em alianças: "In a sense, then, both systems give a role to alliance. The balance of power system requires that some actor join with some other to meet the threat of hegemony by a third; no rule requires all to become involved. Collective security appears to differ by demanding participation of all nations." 356

Feitos esses comentários, passa-se a expor apontamentos desenvolvidos por Morgenthau acerca do equilíbrio de poder e sua influência sobre a formação de alianças.

Morgenthau claramente traça uma linha direta entre o equilíbrio de poder e a formação de alianças. Antes de se deter sobre tal, Morgenthau expõe brevemente sobre os demais métodos do equilíbrio de poder, como a divisão de poderes (impedir determinadas unidades de se juntarem), a concessão de compensações (muitas vezes de natureza territorial, ${ }^{357}$ visando a manter um certo equilíbrio de poder entre determinadas nações) e a diminuição do potencial armamentista.

Sem embargo, é sobre as alianças que Morgenthau se debruça, quando se trata de analisar as manifestações do equilíbrio de poder, ao indicar que a mais importante delas se perfaria justamente no equilíbrio entre uma nação ou uma aliança de nações com outra aliança: "[T]he historically most important manifestation of the balance of power, however, is to be found not in the equilibrium of two isolated nations but in the relations between one nation or alliance of nations and another alliance". 358

Segundo Morgenthau, as alianças se operariam dentro dos dois principais padrões do equilíbrio de poder, consistentes no padrão de oposição direta e no de competição. No primeiro, identifica-se uma situação em que uma nação (A) pretende estabelecer seu poder sobre outra (B), que se recusa a tanto. No segundo caso, uma determinada nação (A) aplica uma política imperialista sobre uma terceira (C), mas sofre resistência de outra nação (B), que mantém uma política de manutenção do status quo ou de dominação em relação a C.

\footnotetext{
$356 \quad$ Friedman (1970), p. 78.

$357 \quad$ Vide nota de rodapé 354 acima.

$358 \quad$ Morgenthau (2006), p. 193.
} 
Para Morgenthau, é diante de tais situações que o equilíbrio de poder opera e cumpre suas funções típicas. ${ }^{359} \mathrm{Na}$ situação de oposição direta, A e B objetivarão aumentar seu poderio em relação ao outro, de forma a obter uma posição de prevalência. A corrida pelo aumento do poder (caracterizado como a soma de elementos de poder, posteriormente definidos por Morgenthau e explorados por outros autores) conduzirá a até que uma nação mude seus objetivos imperialísticos ou que uma delas obtenha uma vantagem decisiva sobre a outra. Nesse caso, a nação mais fraca se sujeitará à mais forte - ou uma guerra resolverá a questão. ${ }^{360}$

Então, avança Morgenthau para indicar que, enquanto o equilíbrio de poder operar com sucesso nessas situações, estará cumprindo duas funções. A primeira se perfaz na criação de uma estabilidade precária, a qual, embora sendo a única estabilidade possível em tal contexto, é, todavia, instável por depender das relações de poder e de força entre as nações participantes da situação em questão. Trata-se de uma instabilidade intrínseca de um sistema de equilíbrio de poder, como classificou o autor.

A segunda função exercida pelo equilíbrio de poder seria a de garantir a liberdade de uma nação em relação à outra. Da mesma forma, uma situação de equilíbrio de poder exercerá a função de salvaguardar a independência de uma terceira nação $(\mathrm{C})$, dentro de um padrão de competição, sendo tal independência uma mera função das relações de poder existentes entre as nações concorrentes (A e B). Morgenthau realça, fazendo referência a Edmund Burke, o quanto um sistema de equilíbrio de poder pode ser útil na preservação da independência de nações pequenas. ${ }^{361}$

\footnotetext{
$359 \quad$ Ibid., p. 185.

"It is in situations such as these that the balance of power operates and fulfills its typical functions. In the pattern of direct opposition, the balance of power results directly from the desire of either nation to see its policies prevail over the policies of the other. A tries to increase its power in relation to $B$ to such an extent that it can control the decisions of $B$ and thus lead its imperialistc policy to success. $B$, on the other hand, will try to increase its power to such an extent that it can resist A's pressure, and thus frustrate A's policy or else embark upon an imperialistic policy of its own with a chance for success. In the latter case, $A$ must, in turn, increase its power in order to be able to resist B's imperialistic policy and to pursue its own with a chance for success. This balance of opposing forces will go on, the increase in the power of one nation calling forth an at least proportionate increase in the power of the other, until the nations concerned change the objectives of their imperialistic policies - if they do not give up altogether - or until one nation gains or believes it has gained a decisive advantage over the other. Then either the weaker yields to the stronger or war decides the issue." (Ibid.)

$361 \quad$ "Small nations have always owed their independence either to the balance of poower (Belgium and the Balkan countries until the Second World War), or to the preponderance o fone protecting power (the small nations of Central and South America, and Portugal), or to the lack of attractiveness for imperialistic aspirations (Switzerland and Spain). The ability of such nations to maintain their neutrality has always been
} 
Nesse contexto, Morgenthau apresenta alguns apontamentos acerca das razões que levam as nações a formar alianças, a mais importante manifestação do equilíbrio de poder. Morgenthau trata as alianças como resultado não de uma atuação principiológica, mas de pragmatismo. Sustenta que uma determinada nação evitará formar alianças se entender que detém poder suficiente para atingir seus objetivos ou se os ônus impostos pelos compromissos decorrentes da aliança sobrepujarem seus bônus.

Forte em tais premissas, Morgenthau indica primeiramente que a formação de alianças depende da existência de alguma identidade de interesses (community of interests). Em tal sentido, a aliança ajudaria a delimitar com maior precisão tais interesses, ${ }^{362}$ até porque, esclarece o autor, a aliança somente se fará necessária quando os interesses em comum, em termos de política e ação, não sejam evidentes. Nesse sentido, uma aliança torna tais interesses comuns mais explícitos e operativos. ${ }^{363}$

No tocante aos interesses em comum, Morgenthau traça distinções entre os tipos de interesses que podem levar à formação de alianças, subdividindo-os em cinco grupos: (i) pela sua natureza e relacionamento; (ii) a distribuição entre benefícios e poder; (iii) sua extensão no tempo; (iv) sua efetividade em termos de políticas e ações comuns. Com base nessas distinções, pode-se identificar se a aliança serve a interesses idênticos, complementares ou ideológicos. ${ }^{364}$

Para este Capítulo, importa examinar a questão da distribuição de benefícios em uma aliança. Morgenthau aponta que a distribuição de benefícios em geral reflete a própria distribuição de poder dentro da aliança. A título ilustrativo, idealmente, o melhor seria que os serviços prestados por cada partícipe da aliança fossem proporcionais aos benefícios por tal auferidos. De outra parte, pode-se também vislumbrar situações em que os benefícios seriam absorvidos por apenas uma das partes aliadas (em verdadeira societas leonina). A distribuição dos benefícios (de poder) reflete portanto uma ideia de distribuição dos ônus e

due to one or the other or all of these factors, for instance, the Netherlands, Denmark, and Norway in the First, in contrast to the Second, World War, and Switzerland and Sweden in both wars." (Ibid., p. 188).

362 "Not every commmunity of interest calling for cooperation between two or more nations, then, requires that the terms of this cooperation be specified through the legal stipulations of a treaty of alliance. It is only when the common interests are inchoate in terms of policy and actions that a treaty of alliance is required to make them explicit and operative." (Ibid., p. 195.)

363 Ibid., p. 195.

$364 \quad$ Vide subcapítulo VI.F.1 abaixo para uma tipologia das alianças. 
bônus da aliança, um ponto de relevância ao se discutir a possibilidade de distribuição dos ônus de uma contramedida em diversos participantes, na medida em que poderá gerar impacto sobre a própria formação da aliança para aplicação das contramedidas, em primeiro lugar. No limite, Morgenthau adverte, com apoio em Maquiavel, que uma nação fraca somente deve entrar em alianças por necessidade, pelo risco de se sujeitar à imposição de seus termos pela nação forte, no tocante à distribuição de benefícios e à implementação de políticas da aliança.

De toda forma, Morgenthau pondera que a questão da distribuição de benefícios não é sempre linear, no sentido de que a detenção de um ativo por uma nação pequena pode ser vista como um fator determinante de interesse por parte de uma nação mais forte, impulsionando a formação da aliança. Como se verá adiante, para alguns autores, trata-se do elemento especificidade de ativos, muito analisado dentro da teoria da firma. ${ }^{365}$

Dentro do prisma temporal, as alianças são em geral temporárias ou prevalecentes enquanto durar o interesse comum subjacente ( $a d$ hoc). No mesmo sentido, determinadas alianças podem até se manter em vigor, formalmente, mas perdurarem inoperantes (isto é, incapazes de coordenar as políticas gerais e as medidas concretas visadas), na medida em que os interesses comuns subjacentes não as impulsionem.

Após delinear os contornos de uma teoria de formação de alianças, Morgenthau passa a analisar as limitações de um sistema de equilíbrio de poder. Ao fazê-lo, concentra crítica em um de seus principais elementos, que se perfaz na capacidade de as nações preverem a composição das alianças. Como anteriormente desenvolvido em sua obra, Morgenthau indica que o poderio das nações deve ser analisado com base nos chamados elementos do poder nacional, a saber: geografia, recursos naturais (alimentos, matériaprima), capacidade industrial, preparo militar (tecnologia, liderança, quantidade e qualidade das forças armadas), população (distribuição, tendências), caráter nacional, moral nacional (sua instabilidade e qualidade da sociedade e governo como fatores decisivos), qualidade da diplomacia e qualidade do governo. ${ }^{366}$

\footnotetext{
$365 \quad$ Vide nota de rodapé 440 e texto que a acompanha.

366 Morgenthau (2006), pp. 122-162.
} 
Morgenthau adverte que a computação dos elementos de poder e sua posterior análise deve considerar alguns pontos, sob pena de se incorrer em determinados erros, como: (i) não considerar como relativo o poderio de determinada nação; (ii) tomar um elemento de poder como fator determinante; e (iii) tomar um elemento de poder como fator determinante permanente.

Como um realista clássico, Morgenthau apresenta seus conceitos permeado de uma série de exemplos históricos, os quais foram omitidos nesta exposição a bem da brevidade e para que se permita avaliar a evolução da sistematização da teoria de formação de alianças. Encerrada a análise de sua contribuição, passa-se a examinar o trabalho de George Liska.

\section{George Liska}

George Liska aparece, ao lado de Morgenthau, como um dos autores clássicos da teoria de formação de alianças, na medida em que também funda a formação de alianças como um meio para realização de ajustes em situações de equilíbrio de poder. ${ }^{367}$

Ao abordar o tema em obra dedicada ao assunto (Nations in Alliances), Liska logo apresenta o que lhe parece ser a razão determinante dos alinhamentos: os conflitos. Para Liska, os conflitos em geral derivam das decisões dos atores em manter ou melhorar sua posição nas arenas global, regional ou doméstica. ${ }^{368} \mathrm{~A}$ isso, Liska denomina de movimento, o qual se opera em um sistema (interação entre os diversos atores), dentro de uma estrutura (número e configuração de poderes [atores] mais ou menos poderosos e dos conflitos). ${ }^{369}$

\footnotetext{
$367 \quad$ Essa conclusão é evidente a partir do seguinte trecho introdutório de sua obra: "The dynamics of alignment is most apparent when two major core-powers are surrounded by lesser allies. On the face of it, the core-powers have attracted the lesser countries into alliance; in fact, superior power does not attract. The weaker state naturally fears that its identity will be abridged by aligning with a more powerful one; and the strong state, too, will often shun association, with the weak for fear of overextending its commitments and resources. Movement toward alignment sets in only when another state intervenes as a threat." (Liska (1962), p. 13). Vide também o seguinte trecho: "[I]n theory, the relation of alliances to the balance of power is simple enough. Put affirmatively, states enter into alliances with one another in order to supplement each other's capability. Put negatively, an alliance is a means of reducing the impact of antagonistic power, perceived as pressure, which threatens one's independence." (Liska (1962), p. 26).

$368 \quad$ Ibid., p.12.

369 Ibid., p.12.
} 
Nesse sentido, o professor da Universidade Johns Hopkins se diferencia de Morgenthau, por identificar potenciais ameaças como as forças motrizes determinantes das alianças. Com efeito, conforme indica Liska, “[A]lliances are against, and only derivately for, someone or something. The sense of community may consolidate alliances; it rarely brings them about. (...) Movement toward alignment sets in only when another state intervenes as a threat." 370

O tipo de conflito que leva à formação de alianças, no entender de Liska, não precisa ser necessariamente um conflito dominante, ou seja, que teria por resultado guindar os vencedores a um papel de preponderância e, com isso, transformar a cultura e estrutura prevalecentes de um sistema. Alianças poderão se formar em torno de questões particulares. Essa seria a característica de um sistema multipolar ideal, que seria nada mais do que um conjunto de bipolaridades parciais ativadas (" a multipolar system is but a set of partial, alternately activated bipolarities").

Ao delinear com maior precisão as razões para um alinhamento, Liska claramente se filia à linha realista. Segundo ele, em termos econômicos, alianças visariam a maximizar ganhos (maximize gains) e a dividir responsabilidades (sharing liabilities). Nesse sentido, a decisão de formar uma aliança ou não, a forma de alinhamento e com quem, se daria com referência aos interesses nacionais, para o que se deve basear a análise em aspectos concretos acerca das condições e dos conflitos, em particular, levando em consideração os objetivos em matéria de segurança, estabilidade e status.

Com efeito, construindo sobre a teoria até então desenvolvida, Liska indica que a razão de um alinhamento seria suplementar as capacidades do outro aliado (maximizar capacidades), visando a implementar o objetivo de deter coletivamente um agressor comum, de maneira eficiente. Nesse ponto, Liska expõe que a atuação de uma aliança deve se dar "economicamente", ou seja, não se deve buscar toda e qualquer aliança disponível nem os compromissos mais elevados - ao contrário, deve-se buscar a utilidade marginal da última unidade de compromisso de um determinado aliado e a última unidade de custos na implementação dos compromissos. ${ }^{371}$

\footnotetext{
$370 \quad$ Ibid., pp.12-13.

$371 \quad$ Ibid., p. 27.
} 
Ao justificar uma definição mais econômica das razões de alinhamentos, Liska invocou uma certa ambiguidade no equilíbrio de poder e a caracterização das alianças como sendo transações ("which are distinct from accidental ties of culture and feeling"), introduzindo as noções de "interesses" e de "ganhos" e "responsabilidades" nas análises e determinações políticas. ${ }^{372}$

No tocante aos interesses, de maneira generalista, Liska apenas aponta que a possibilidade de alinhamento aumenta com a identidade dos interesses, embora admita que basta a possibilidade de certa compatibilidade em torno de um interesse comum. Adiciona o autor que as chances de convergência aumentam quando os interesses são complexos, compreendendo interesses idênticos, díspares ou mesmo conflitantes, dentro de uma escala de valoração diferenciada para cada potencial aliado. ${ }^{373}$

Liska trata dos "ganhos" e "responsabilidades", listando os três principais fundamentos de alianças (segurança, estabilidade interna e status). Dentro dessa discussão, interessa ressaltar um ponto que adiante será de relevância substancial, que é a necessidade de se comparar os "ganhos" e "responsabilidades" obtidos no contexto de uma determinada aliança com os "ganhos" e "responsabilidades" que poderiam ser obtidos no contexto de uma outra aliança. ${ }^{374} \mathrm{Ou}$ seja, a possibilidade de uma determinada aliança ser formada depende de uma análise comparativa com as outras possíveis alternativas de alinhamento.

Além de dar uma série de exemplos históricos ilustrando as situações teóricas expostas, Liska passa a tratar dos processos de realinhamento, desalinhamento e os elementos de coesão das alianças. Liska identifica as causas do realinhamento e desalinhamento como sendo coerção (definida como pressão forte e efetiva, em que a impossibilidade de resisti-la constrange uma nação a reavaliar a estrutura de "ganhos" e "responsabilidades"), conflito de interesses e estratégias entre aliados (mudança nos interesses se perfaz em causa interna corporis para re- ou desalinhanento) e alterações na

372 "[T]he ambiguity of the balance of power, and the innermost character of alliances as transactions which are distinct from accidental ties of culture and feeling, conspire to inject the notions of 'interest' and of 'gains' and 'liabilities' into both analysis and policy determination." Ibid., p. 27.

373 Ibid., p. 28.

374 "In order to assess a particular alignment, all these factors must be compared with hypothetical gains and liabilities of other alignments; with non-alignmen; or at least with a different implementation of an unavoidable alliance." Ibid., p. 30. 
autoridade doméstica ou nas relações de poder. Trata-se, portanto, de mudanças baseadas na dinâmica das relações e dos interesses componentes da aliança.

Liska destaca o papel da "paz em separado" (separate peace) quanto a eventuais desalinhamentos, ou seja, a propensão de um membro da aliança dela se retirar para obter paz imediatamente ou no período pós-conflito. ${ }^{375}$ Como ilustra Liska, em contextos envolvendo um ente hegemônico, o oferecimento de "paz em separado" se perfaz em instrumento eficaz para isolar o oponente principal. ${ }^{376}$ Em contraposição, para se evitar tal propensão pró-desalinhamento, o aliado principal deverá controlar um ativo indispensável que torne impossível a transação para seu aliado - ou não desejável para o oponente. ${ }^{377}$

As indicações de Liska quanto à necessidade de comparação entre as alternativas de alianças disponíveis aos autores, baseadas na identificação da propensão de se aliar, foram posteriormente desenvolvidas com maior detalhamento, nos estudos que se seguiram.

\section{Estudos subsequentes aos clássicos: tentativas de sistematização e formalização}

Estudos subsequentes a Morgenthau e Liska conferiram metodologia mais precisa e técnica aos conceitos abstratos e históricos desenvolvidos por tais autores no tocante à formação de alianças.

Mancur Olson e Richard Zeckhauser expuseram, em 1966, um dos mais eloquentes artigos acerca da formação de alianças. ${ }^{378} \mathrm{O}$ texto se constrói dentro da teoria de bens coletivos (collective goods), já objeto de extensos estudos por parte de Olson. ${ }^{379}$

\footnotetext{
375 "The choice will be determined by experimentally discovered propensity of individual powers for an immediate arrangement and possible postwar alignment." Ibid., p. 43.

376 Como explica Liska, em termos gerais, a questão da paz em separado é uma questão de ganhos e perdas e sua duração. Uma parte a quem se oferta proposta de paz em separado em geral recebe oferta em melhores termos do que em uma oferta de paz geral (Ibid., p. 48). Nisso, Liska identifica nada mais do que a própria ideia de equilíbrio de poder: "[I]n any event, the balance of power is the source of the most fundamental dilemma of separate peace. A party follows its dictates when deserting a tôo successful ally; a defector violates these dictates when he initiates a stampede away from the losing side." Ibid., p. 55. $377 \quad$ Ibid., p. 43.

378 Olson e Zeckhauser (1966)

379 Olson (1965).
} 
Com efeito, Olson e Zeckhauser enfocam a análise da formação de alianças a partir de uma perspectiva da teoria de bens coletivos: o papel de um estado-nação é de prover os bens coletivos desejados pela coletividade (segurança, por exemplo); da mesma forma, uma aliança tem por objetivo prover um determinado bem coletivo, no caso, não a indivíduos, mas a estados-nação. ${ }^{380}$

Dentro dessa matriz, desenvolvem Olson e Zeckhauser, interesses individuais em geral são melhor atendidos por ações individuais, mas quando um determinado grupo de indivíduos tem interesses em comum ou objetivos coletivos, então uma organização pode ser útil. ${ }^{381}$

Um bem coletivo detém uma ou duas das seguintes propriedades: (i) se o objetivo pretendido é atingido, todos os indivíduos desejosos de tal objetivo dele se beneficiam automaticamente; e (ii) se o bem se fizer disponível para um indivíduo no grupo, estará disponível aos demais a um custo pequeno ou marginal. Essas propriedades levam ao conhecido problema do "free rider", ou seja, uma conduta oportunista de se beneficiar do bem coletivo, por parte de quem nada ou pouco tenha contribuído para sua obtenção (ou geração). Em grandes grupos, em que é difícil o monitoramento das ações dos diversos indivíduos e a parcela individual de contribuição é pequena, o problema de tal conduta oportunista se acentua, diminuindo os incentivos para que os indivíduos contribuam voluntariamente para obtenção/geração do bem coletivo. ${ }^{382}$

Concluem então Olson e Zeckhauser que, em uma instituição (ou aliança) com pequena membresia, os indivíduos poderão ter um incentivo para contribuir para a obtenção/geração do bem coletivo, mas a tendência é que o farão em um patamar subótimo. Por fim, defendem que, em equilíbrio, haverá uma tendência a que os indivíduos que tenham maior interesse na obtenção do bem coletivo arquem com uma parcela desproporcional de seu custo. Tal conclusão deriva da premissa de que, em uma aliança, a

\footnotetext{
$380 \quad$ Olson e Zeckhauser (1966), p. 177.

"Indeed, almost all kinds of organizations provide public or collective goods. Individual interest normally can best be served by individual action, but when a group of individuals has some common objective or collective goal, then an organization can be useful." Olson e Zeckhauser (1966), pp. 177-178. 382 Olson e Zeckhauser (1966), pp. 177-178.
} 
quantidade a ser despendida por uma nação para obtenção de um bem coletivo (defesa, por exemplo) dependerá dos gastos expendidos pelos demais membros. ${ }^{383}$

Em concomitância à época da publicação do artigo de Olson e Zuckhauser (1966), John G. Cross publicou artigo com algumas proposições baseadas na teoria econômica para abordar a formação de alianças. Cross não se deteve sobre a questão de bens coletivos, mas aplicou um modelo de mercado competitivo (de teoria econômica) à formação de coalizões. ${ }^{384}$ Para tanto, Cross utilizou-se de duas premissas, a saber: (i) membros de uma aliança são motivados pela vontade de maximizar o valor (para eles próprios) da membresia do grupo; e (ii) membresia em um determinado grupo exclui membresia em outro, de forma que a escolha entre alternativas passa a ser uma questão determinante. Ao assim estabelecer, Cross aprofundou a análise até então desenvolvida, colocando no centro da discussão a questão do exame comparativo entre as opções de coalizões existentes. Nesse sentido, Cross explorou modelos competitivos de formação de coalizões, os quais, baseados em estruturas de payoffs, permitiriam verificar a probabilidade de formação de coalizões entre determinados agentes. ${ }^{385}$

Em artigo de 1968, Bruce M. Russett tratou de algumas questões importantes acerca do desenvolvimento de uma teoria de formação de alianças e sua aplicação às relações internacionais. Com base na contribuição para as ciências sociais feita por William Riker (um dos pioneiros em aplicar a teoria dos jogos e outras formulações mais rigorosas a tais ciências), ${ }^{386}$ Russett tratou da questão do "princípio do tamanho" (size

\footnotetext{
383 Para tanto, Olson e Zeckhauser trabalharam com curvas de indiferença e de reação para determinar o ponto de equilíbrio nos gastos de defesa por cada participante: "Figure 2 shows the reaction curves for a two-country model (which can easily be generalized to cover $N$ countries). The intersection point of the two reaction curves indicates how much of the alliance good each ally will supply in equilibrium. The two reaction curves need not always intersect. If one nation has a very much larger demand for the alliance good than the other, its reaction curve may lie at every point outside that of the other, in which case it will provide all of the defense. The equilibrium output will then be the same as the isolation output of the country with the largest isolation output. Whether the reaction curves intersect or not, the equilibrium output is necessarily determinate and stable unless defense is an inferior good, in which case there may be a number of equilibria, one or more of which may be unstable." (Olson e Zeckhauser (1966), pp. 180-181).

$384 \quad$ Nesse sentido, Cross sustentou que definir qual seria a "melhor" aliança em uma determinada situação equivaleria a buscar o menor preço para um determinado produto (Cross (1967), p. 199).

385 Cross (1967), pp. 199-214.

386 William H. Riker mesmo indica a possibilidade de aplicação das matrizes da teoria dos jogos sobre as relações internacionais: "The development in the sixteenth century of the system of European nation-states and the fairly recent extension of this system to the whole world created a pattern of international politics which is very like an n-person game. The players are the nations, but otherwise the rules are rather vague. Often, and especially now when there is threat of nuclear war, the game has seemed non-zero-sum, that is the common benefits of peace and civilization have seemed greater than any possible gain from conflict. But occasionaly international politics turns into a zero-sum game as when total war has occurred or when
} 
principle), segundo o qual determinados indivíduos (atores) formarão o menor grupo com o qual seja possível prevalecer - e não mais que o necessário para tal propósito ("the principle that the players will form that grouping which is the smallest winning coalition, that contains just enough power to gain the decision, but no more than is necessary for the purpose"). ${ }^{387}$ Isso para evitar que, no pós-vitória, se tenha de dividir os louros com quem não tenha contribuído decisivamente para tanto. ${ }^{388}$

Russett aponta algumas dificuldades percebidas em tal princípio, enfatizando aquelas relacionadas à mensuração do poderio das nações, já que não indica como os pesos das diferentes nações seriam calculados para fins de se determinar qual seria a "menor coalizão vencedora". ${ }^{389}$ Bruce M. Russett explora essa questão, apontando que, baseado em estudos conduzidos por William Gamson, em situações em que os payoffs de duas coalizões alternativas são equivalentes, um determinado ator (em geral, a nação média) ${ }^{390}$ ficará indiferente quanto à sua escolha, podendo decidir com base em "preferências estratégicas não-utilitárias”. Para Russett, no contexto das relações internacionais, essas "preferências estratégicas não-utilitárias" consistiriam em "laços de interesses comuns" (como ideologia, por exemplo), já que não relacionados diretamente com os interesses de poder objetivamente resultantes de uma vitória ou derrota. ${ }^{391}$

Ainda no tocante à "menor coalizão vencedora", Russett indica (com base em Theodore Caplow) que, como cada ator busca controlar a coalizão, entre duas alternativas, preferirá aquela em que tenha um ator mais fraco. ${ }^{392}$ Em situações envolvendo mais do que três atores, os custos de negociação serão relevantes, constituindo mais uma variável, pois coalizões com dois membros são mais fáceis de serem formadas do que com três

politics is practiced inside an institution like the United Nations with its essentially zero-sum decisionprocesses. If it does become an analogue of a zero-sum game, the experience of international politics also becomes relevant evidence about the model." (Riker (1962), pp. 272-273).

$387 \quad$ Russett (1968), pp. 239-240.

388 "This is attributed to a desire on the part of the potential winners not to spread the winnings out among superfluous partners - the fewer the actors who must be rewarded, the greater the payoff to those who are rewarded." (Russett (1968), p. 240). Conforme as palavras do próprio Riker: "In social situations similar to n-person, zero-sum games with side payments, participants create coalitions Just as large as they believe will ensure winning and no larger." (Riker (1962), p. 263).

$389 \quad$ Russett (1968), p. 240.

390 Russett (1968), p. 251. Essa nação média (middle power) parece constituir o que Morgenthau classifica como o "holder of the balance". Morgenthau (1948), pp. 204-208.

391 Russett (1968), p. 241. O papel da ideologia é uma constante preocupação de alguns teóricos que analisaram a formação de alianças, até porque desenvolvida em plena Guerra Fria.

$392 \quad$ Russett (1968), p. 245. 
membros. ${ }^{393}$ Outros pontos desenvolvidos por Russett se referem aos problemas relativos à mensuração do poderio nacional, em especial quanto à assimetria de informações existentes, além da possibilidade de inclusão de side payments dentre os elementos a serem considerados na formação de coalizões.

Robert L. Rothstein tratou da alternativa de neutralidade, em geral considerada por pequenas nações, indicando que países pequenos em geral preferem a neutralidade, a não ser que convencidos da possibilidade de alterar o resultado do conflito, hipótese em que poderão se aliar. ${ }^{394}$

Seguiram-se, na década de 70, diversos estudos, aplicando os conceitos sobre a formação de alianças a diversos contextos, com forte ênfase em métodos quantitativos (aplicação de modelos econômicos e/ou matemáticos ${ }^{395}$; estudos com objetivos estatísticos; entre outros).

Dentre esses estudos, vale mencionar Singer e Small (1966), que analisaram 112 tratados (alianças formais) firmados entre 1815 e 1939, visando a descrevê-los quantitativamente. Para tanto, os autores investigaram seus signatários, datas de assinatura e período de vigência, e classificaram o tipo de compromisso adotado (pacto de defesa; neutralidade ou não-agressão; ou de consultas ou cooperação em tempos de crise). Em seguida, agregaram os resultados de maneira a permitir uma análise de seu significado no tocante ao sistema internacional. Ao final, os autores procuraram descrever o objeto de estudo da forma mais completa possível, para facilitar estudos futuros. O trabalho realizado tem natureza descritiva, não tendo por objeto elaborar ou corroborar alguma teoria de formação de alianças. Três anos depois, Singer e Small (1969) realizaram o mesmo estudo de Singer e Small (1966), mas estendendo o período analisado de 1816 a 1965.

Altfeld e Bueno de Mesquita (1979) apresentaram uma teoria baseada em escolha racional acerca de como tomadores de decisão escolhem lados, ou neutralidade, em relação a determinadas guerras. Para tanto, a teoria foca na utilidade esperada (expected utility) de

\footnotetext{
$393 \quad$ Russett (1968), p. 247.

$394 \quad$ Rothstein (1962).

395 Sandler e Hartley (2003), p. 869, listam outros tantos trabalhos desenvolvidos a partir do trabalho seminal Olson e Zeckhauser (1966).
} 
uma guerra para cada nação e a utilidade esperada para cada alternativa disponível para aquela mesma nação. O principal objetivo do estudo foi identificar o cálculo de tomada de decisão que permitiria a um tomador de decisão prever o comportamento esperado de terceiros partes em um determinado conflito. $\mathrm{O}$ estudo proposto parte da definição de resultados (outcomes) e da premissa de que tomadores de decisão se comportam como se eles calculassem a utilidade esperada a se derivar de um resultado de uma guerra e a utilidade esperada a se derivar de cada uma das estratégias alternativas disponíveis. Para tanto, definiram-se dois resultados possíveis para a guerra em questão (o combatente mais forte prevalece; e o combatente mais fraco prevalece), e duas estratégias alternativas para terceiras nações poderem escolher (a terceira nação se junta ao combatente mais forte; e a terceira nação se junta ao combatente mais fraco). Nesse sentido, excluindo-se a possibilidade de a terceira nação intervir, a expectativa é que o combatente mais forte prevaleça. Em caso de intervenção, a terceira nação poderá mudar o resultado esperado ao se aliar ao combatente mais fraco. Mesmo no caso de se aliar ao combatente mais forte, sua junção altera a perspectiva de vitória do combatente mais forte (reforça-a). Nesse sentido, a decisão a ser tomada pela terceira nação depende (é uma função) de uma comparação entre as utilidades esperadas de cada uma das duas situações (escolherá a alternativa que resultar em uma utilidade maior, salvo se se equivalerem, caso em que escolherá a neutralidade).

Altfeld e Bueno de Mesquita (1979) formularam matematicamente tais conceitos, de que retiram algumas conclusões: é maior a probabilidade de nações mais fortes se juntarem a um aliado durante um combate, do que nações mais fracas (ou seja, os interesses [ou utilidade] de países mais poderosos não precisam ser tão evidentes (ou elevados) para conduzi-los a se aliarem em um confronto, diferentemente de nações mais fracas). Os autores então ressaltam o papel da incerteza na definição da informação necessária para realização dos cálculos de utilidade, atribuindo pesos no caso de a tomada de decisão ocorrer em um momento de maior ou menor confiança. ${ }^{396}$ Com base nas alianças identificadas e examinadas no estudo de Small e Singer (1969), Altfeld e Bueno

\footnotetext{
$396 \quad$ "We have assumed that uncertainty about the expected behavior of other states affects the response of $C$ to an ongoing war. In particular, uncertainty affects the information $C$ is able to substitute into equation 4 to make its calculations. For instance, shifts in the composition and alignments of the international system make it difficult for $C$ to evaluate the foreign policy preferences of $S$ and $W$ vis-à-vis all other states. Indeed, such shifts may even make it difficult for $C$ to define the full panoply of its own interests until it is able to sort out the policy implications of shifts in either the composition of the international system, or in the distribution of alliances and the priority of issues." Altfeld e Bueno de Mesquita (1979), pp. 91-93.
} 
de Mesquita (1979) aplicaram o modelo acima brevemente descrito, para concluir por sua eficácia em predizer as escolhas dos países, sugerindo que tomadores de decisão se comportam como se realizassem os cálculos indicados no modelo. ${ }^{397}$

\section{Kenneth Waltz (1979): Realismo estruturalista: A formação de alianças como corolário do equilíbrio de poder}

Em 1979, Kenneth N. Waltz, maior expressão do realismo estruturalista, tratou da questão da formação de alianças, focando-a no contexto do equilíbrio de poder. Ao fazê-lo, o professor de relações internacionais da Universidade Columbia primeiramente analisou a estrutura do sistema internacional, caracterizando-o como uma anarquia. Nesse contexto, destacou a inexistência de um poder central (governo), que detenha o monopólio do uso legítimo da força, deixando os estados em uma situação de self-help (auto-socorro). ${ }^{398}$

Segundo Waltz, em uma estrutura anárquica, unidades (units) são funcionalmente similares e tendem a permanecer como tais. Unidades similares trabalham para manter uma medida de independência. Em sistemas hierárquicos, por sua vez, as unidades são diferenciadas, tendendo a aumentar a extensão de tal especialização. O aumento da especialização, por sua vez, provoca uma maior interdependência ("integração"). Avançando sobre o sistema internacional, Waltz ressalva que as capacidades das unidades dentro de um sistema internacional (as nações) se diferenciam enormemente, havendo instâncias de divisão de trabalho e, portanto, interdependência. ${ }^{399}$

Em um sistema de self-help, cada unidade despende uma parte de seus esforços para obter meios para se proteger dos demais. Em tal sistema, prossegue Waltz, a preocupação em relação à sua proteção condiciona o comportamento de cada unidade. A partir daí, como em um mercado oligopolista, a maximização dos ganhos para todas as unidades depende de uma cooperação plena, sem desvios (i.e., condutas oportunistas). ${ }^{400}$

\footnotetext{
$397 \quad$ Altfeld e Bueno de Mesquita (1979), pp. 110-111.

$398 \quad$ Waltz (2010), pp. 102-104.

399 Waltz diferencia integração e interdependência. O primeiro se aplica a unidades componentes de uma nação; o segundo se refere ao relacionamento entre nações. Integração traz uma nação unida ao passo que a interdependência entre nações mantenha-as ligeiramente conectadas. Integração entre nações ocorre raramente (Ibid., pp. 104-105).

$400 \quad$ Adiante, Waltz equivale essa situação ao Dilema dos Prisoneiros. "The very problem, however, is that rational behavior, given structural constraints to take care of itself, no one can take care of the system. [nota de rodapé: Put differently, states face a 'prisoners' dilemma'. If each of two parties follows his own
} 
No sistema internacional, isso equivaleria a um desarmamento total das unidades. Waltz (apoiado em Fellner) afasta tal hipótese, pois "a possibilidade de uma guerra renovada sempre existe". 401

Além disso, em um sistema internacional, a cooperação é dificultosa, pois não se sabe ao certo como será a partilha dos ganhos oriundos da contribuição de todos (a pergunta dominante é saber quem ganhará mais - não se todos ganharão). ${ }^{402} \mathrm{O}$ uso de capacidades desproporcionais por parte de uma unidade, para garantir auferir uma maior quantidade de ganhos, colocará a cooperação em risco ("Instead, the condition of insecurity - at the least, the uncertainty of each about the other's future intentions and actions - works against their cooperation"). ${ }^{403}$

A segunda forma pela qual a estrutura do sistema internacional limita a cooperação entre as unidades é o receio de ficar dependente dos demais por meio da cooperação ou intercâmbio de bens e serviços. Quanto mais importar ou exportar, mais dependerá dos demais. Quanto mais se especializar, mais dependerá dos demais. Um elevado grau de interdependência entre unidades experimenta uma comum vulnerabilidade, advinda de tal interdependência; o que explica a busca (ou luta ["struggle"], como classificaria Morgenthau), por cada unidade/estado, de aumentar o controle sobre os demais e, por outro lado, elevar sua independência. ${ }^{404}$

Dentro desse contexto, Waltz procura construir uma teoria consistente de relações internacionais, colocando em seu centro exatamente a teoria de equilíbrio de poder. Waltz

interest, both end up worse off than if each acted to achieve joint interests. For thorough examination of the logic of such situations, see Snyder and Diesing 1977; for brief and suggestive international applications. See Jervis, January 1978." (Ibid., p. 109).

$401 \quad$ Ibid., pp. 105-106.

$402 \quad$ "In a self-help system each of the units spends a portion of its effort, not in forwarding its own good, but in providing the means of protecting itself against others. Specialization in a system of divided labor works to everyone's advantage, though not equally so. Inequality in the expected distribution of the increased product works strongly against extension of the division of labor internationally. When faced with the possibility of cooperating for mutual gain, states that feel insecure may ask how the gain will be divided. They are compelled to ask not "Will both of us gain?" but "Who will gain more?" If an expected gain is to be divided, say, in the ratio of two to one, one state may use its disproportionate gain to implement a policy intended to damage or destroy the other. Even the prospect of large absolute gains for both parties does not elicit their cooperation so long as each fears how the other will use its increased capabilities. Notice that impediments to collaboration may not lie in the character and the immediate intention of either party. Instead, the condition of insecurity - at the least, the uncertainty of each about the other's future intentions and actions - works against their cooperation." (Ibid., p. 105).

$403 \quad$ Ibid., p. 105.

$404 \quad$ Ibid., pp. 105-106. 
revolve aos conceitos da Realpolitik, não como uma política de relações internacionais, mas como uma teoria de relações internacionais. Para tanto, retoma Maquiavel (como predecessor teórico), Meinecke e Morgenthau. Ao dar as bases da Realpolitik, Waltz destaca os pressupostos de tal teoria, a saber: os interesses dos atores/unidades determinam suas ações; as necessidades das unidades advêm da não regulada competição entre os estados (quando atores são constrangidos por força e competição, ao invés de autoridade e a lei); cálculos baseados em tais necessidades podem permitir descobrir as políticas que melhor servirão aos interesses das nações em questão; o sucesso se perfará no teste final, e se definirá em termos de preservação ou fortalecimento do estado. ${ }^{405}$

Dada essa estrutura, a teoria de equilíbrio de poder emerge, na visão de Waltz, como $a$ teoria de relações internacionais ("[I]f there is any distinctively political theory of international politics, balance-of-power theory it is."), ${ }^{406}$ a qual se basearia em dois pressupostos, a saber: anarquia e unidades buscando preservação. ${ }^{407}$

Para atingir os objetivos pretendidos, as unidades (estados) utilizam-se em geral dos meios disponíveis, os quais caem em duas categorias: esforços internos e esforços externos. Enquanto os primeiros se perfazem em movimentos para aumentar suas capacidades (militares, econômicas, estratégicas, entre outros), os segundos se constituem em reforçar ou alargar alianças próprias ou enfraquecer ou reduzir as de oponentes.

Ao assim definir as possibilidades do jogo externo (alinhamento e realinhamento), Waltz obviamente coloca a formação de alianças no centro da teoria de equilíbrio de poder e, por conseguinte, na sua teoria de relações internacionais.

Kenneth N. Waltz apresenta então comentários sobre os comportamentos de balancing e bandwagoning (ressaltando terem sido introduzidos por Stephen Van Era), sendo o primeiro o comportamento de se opor a uma determinado agente dominante (comportamento equilibrante) e o segundo o seu oposto, ou seja, de se aliar ao agente dominante (comportamento seguidor). Balancing faria sentido, no entender de Waltz, quando a vitória de uma coalizão sobre outra deixa as unidades mais fracas dessa coalizão

\begin{tabular}{ll}
\hline 405 & Ibid., p. 117. \\
406 & Ibid., p. 117. \\
407 & Ibid., p. 118.
\end{tabular}

Ibid., p. 118 . 
à mercê das mais fortes. Nesse sentido, entre uma coalizão fraca e outra forte, as unidades prefeririam se juntar à coalizão fraca, sob pena de se sujeitar ao aliado mais forte, póssucesso (isso, desde que a coalizão mais fraca reúna poderio defensivo suficiente para dissuadir ataques da coalizão mais forte). ${ }^{408}$ Para tanto, Waltz considera que a detenção de poder é somente um meio - não um fim; do contrário, se maximização de poder fosse o comportamento dominante, as unidades prefeririam se juntar às coalizões mais fortes, levando não à formação de coalizões, mas à de uma hegemonia mundial. ${ }^{409}$ Ao contrário, sustenta Waltz, o comportamento dominante é de equilíbrio (balancing), não de se bandear (bandwagoning), já que as unidades querem manter suas posições, ao invés de maximizar poder.

Waltz não desenvolve uma teoria específica de formação de alianças, devotando o restante de sua clássica obra sobre uma estrutura ótima de um sistema internacional (em que sustenta que um sistema com dois entes hegemônicos seria o de maior estabilidade, dentro do equilíbrio de poder), bem como acerca de questões relativas à administração de assuntos internacionais.

\section{E. Stephen M. Walt: O Equilíbrio de Ameaças}

Como um dos principais estudiosos do assunto, Stephen M. Walt, em sua obra "The Origins of Alliances", apresenta as seguintes questões como objeto de sua análise: o que leva países a dar suporte à política externa dos demais; como governantes escolhem entre potenciais ameaças quando em busca por apoio externo; como grandes potências escolhem quais estados proteger, e como estados mais fracos decidem qual proteção aceitar. Como o próprio Walt resume: "[I]n short, how do states choose their friends?". 410

Definem-se "alianças" como as relações formais ou informais de cooperação entre dois ou mais países soberanos. Conforme o professsor de relações internacionais de Harvard sustenta, a importância do estudo da formação de alianças (ou coalizões) é manifesta, lembrando assertiva de Morgenthau de que alianças "são uma função necessária

\footnotetext{
408 "Secondary states, if they are free to choose, flock to the weaker side; for it is the stronger side that threatens them. On the weaker side, they are both more appreciated and safer, provided, of course, that the coalition they join achieves enough defensive or deterrent strength to dissuade adversaries from attacking." (Ibid., p. 127).

$409 \quad$ Ibid., p. 126.

$410 \quad$ Walt (1983), p. 1.
} 
do equilíbrio de poder operante em um sistema de estado múltiplo".

Walt constrói sua visão acerca da formação de alianças a partir de alguns conceitos, sendo dois dos principais a possibilidade de adoção de comportamento equilibrante (balancing behavior) ou comportamento seguidor (bandwagoning behavior) do país mais forte.

A ideia de comportamento equilibrante deriva da noção muito difundida de que países mais fracos tenderiam a se alinhar para evitar que países mais fortes os dominem. Como visto anteriormente, tal conceito foi bastante explorado nos estudos clássicos sobre a formação de alianças, com especial ênfase na obra de Morgenthau (2006). Tal posicionamento estratégico se sustentaria pela tentativa de frear o fortalecimento de um ente hegemônico, antes que seja tarde. Outra razão seria o fato de se garantir uma posição de maior influência dentro da coalizão entre os mais fracos, em vez de simplesmente manter uma posição de seguidor do ente hegemônico.

O comportamento seguidor, como a própria expressão indica, denota a atitude de um país de se aliar a um estado mais forte. Duas razões explicariam tal comportamento: seria uma forma de neutralizar (appeasement) um eventual ataque por parte do país mais forte, além de uma conduta oportunista de, terminado o conflito, compartilhar do espólio dos países vencidos (aqui logo se identifica uma direta referência a uma situação de conflito armado).

Walt indica, contudo, que tais estratégias nada mais são do que formas de se lidar com ameaças, partindo, então, para identificar o grau de ameaça posto por um determinado país.

Para tanto, Walt pondera que, para além da teoria de equilíbrio de poder, a teoria de equilíbrio de ameaças não se basearia apenas na análise dos elementos do poder nacional população, capacidades econômicas e militares, capacidade tecnológica, coesão política, entre outros. Para Walt, a formação de coalizões ocorre quando a nação ou coalizão mais ameaçadora é significativamente mais forte (perigosa) que a segunda nação ou coalizão mais ameaçadora. 
A medida de ameaça de uma determinada nação ou coalizão seria então um produto dos seguintes elementos: ${ }^{411}$

(i) poder acumulado: cumulação dos recursos totais detidos por um país, como, população, capacidade industrial e militar, desenvolvimento tecnológico, entre outros (tal qual na teoria de equilíbrio de poder);

(ii) proximidade geográfica: fator importante, pois a capacidade de causar ameaça diminui com a distância (tal qual na teoria de equilíbrio de poder);

(iii) poder ofensivo: países com maior poder ofensivo tendem a provocar alianças; e

(iv) intenções agressivas dos países envolvidos: uma reputação de agressividade pode ser um componente importante na formação de alianças, levando a comportamentos equilibrantes.

A partir desses conceitos, conclui Walt que a definição da probabilidade de formação de alianças com base em ameaças - ao invés de poder - proporciona uma matriz de análise mais precisa, pois compara as fontes de ameaça: quanto maior a ameaça maior a probabilidade de países vulneráveis buscarem alianças contra ela. ${ }^{412}$

Em suma, após desenvolver o tema a partir da análise dos conflitos no Oriente Médio, Walt sustenta que a origem das alianças não reside na questão do equilíbrio de poderes (balance of powers), mas no equilíbrio de ameaças, (balance of threats), refinando e redefinindo a teoria.

Como o próprio Walt expõe: ““(...) Balance-of-threat' theory should be viewed as a refinement of balance-of-power theory. Where balance-of-power theory predicts that states ally in response to imbalances of power, balance-of-threat theory predicts that states seek allies when there is an imbalance of threat (that is, when one state or coalition is specially dangerous). The two theories are equally parsimonious, but balance-of-threat theory is more general and abstract. As shown in Figure 1, the main concept informing balance-ofthreat theory is the distribution of capabilities, which is based on population, economic

$411 \quad$ Walt (1985), pp. 8-13.

$412 \quad$ "By defining the basic hypotheses in terms of threat rather than power alone, we gain a more complete picture of the factors that statesmen will consider when making alliance choices. One cannot determine a priori, however, which sources of threat will be most important in any given case; one can say only that all of them are likely to play a role. And the greater the threat, the greater the probability that the vulnerable state will seek an alliance." Walt (1983), p. 26. 
capacity, military power, political cohesion, etc. The central concept of balance-of-threat is the distribution of threats, which consists of capabilities, proximity, offensive power, and intentions. Thus, both theories are based on a single concept incorporating a number of components, although balance-of-threat theory subsumes balance-of-power theory by incorporating capabilities, geography, and intentions. As we shall see, it offers a more compelling explanation of alliance choices than an exclusive focus on the distribution of capabilities does". 413

Para Walt, balancing é o comportamento dominante. A decisão por um ou outro comportamento, todavia, seria determinada por alguns fatores. Entre tais, Walt discorre sobre o tamanho do país, para indicar, apoiando-se em Rothstein (1962), que países pequenos, em geral, adotam um comportamento seguidor caso identifiquem que não detêm meios (capacidade) para alterar o resultado de um determinado conflito. ${ }^{414}$ Ou seja, somente quando sua decisão pode alterar o resultado final é que fará sentido aos países menores adotarem um comportamento equilibrante. Em reverso, faz sentido países maiores adotarem um comportamento equilibrante, pois, em geral, sua decisão pode transformar uma aliança perdedora em vencedora.

No tocante à proximidade geográfica, Walt pontua que países menores serão mais sensíveis a questões ou eventos ocorridos em sua vizinhança, o que poderá influir em sua decisão sobre a adoção de um comportamento equilibrante ou seguidor.

Walt ainda aponta que a adoção de um ou outro comportamento dependerá também de um fator simples: a disponibilidade de aliados. Caso não haja aliados disponíveis para formação de uma coalizão equilibrante, não restará alternativa a um determinado país a não ser adotar um comportamento seguidor. ${ }^{415}$

Por fim, Walt indica que o contexto de formação de uma determinada coalizão é relevante, pois países tendem mais a um comportamento equilibrante durante tempos de paz do que em tempos de guerra, especialmente quando o resultado da guerra já comece a ficar mais aparente. A restauração da paz, no entanto, recriaria os incentivos para adoção

$\begin{array}{ll}413 & \text { Walt (1988), p. } 281 . \\ 414 & \text { Walt (1987), pp. 26-31. } \\ 415 & \text { Ibid., pp. 30-31. }\end{array}$


de comportamentos equilibrantes. ${ }^{416}$

Em resumo, Walt apresenta os seguintes achados no tocante à adoção de comportamentos equilibrantes e seguidores:

- Comportamento equilibrante é mais comum do que comportamento seguidor;

- Quão mais forte for um país, maior é a tendência de adoção de comportamento equilibrante. Países mais fracos tenderão a equilibrar outros países fracos, mas tenderão a seguir países mais fortes, quando ameaçados;

- Quão maior a probabilidade de suporte aliado, maior a tendência ao equilíbrio. Não obstante, quanto mais certa for tal probabilidade, maior o risco de comportamentos oportunistas (free-riding);

- Quanto mais agressivo um país aparentar ser, maior a probabilidade de outros adotarem comportamentos equilibrantes;

- Em tempos de guerra, quanto mais perto um lado se encontre da vitória, maior a tendência de outros o seguirem.

A partir desse arcabouço, Walt ainda analisa o efeito da ideologia e da existência de instrumentos políticos entre determinados países (fornecimento de ajuda econômica ou militar ajuda na criação de alianças leais) sobre sua propensão em se aliarem, embora diminuindo sua importância.

Mais recentemente, Walt ofereceu outra contribuição relevante para a teoria de formação de alianças, ao identificar diferentes técnicas de balancing, que têm se desenvolvido em um mundo unipolar (Walt classifica a estrutura do sistema internacional atualmente como "unipolar"). ${ }^{417}$ Nesse contexto, a ideia parte de um continuum (desde, em uma extremidade de oposição ao unipolar, hard balancing, passando por soft balancing, "leash-slipping", neutrality, bandwagoning até, na extremidade oposta de apoio ao unipolar, regional balancing), refletido a seguir:

\footnotetext{
$416 \quad$ Ibid., p. 31.

$417 \quad$ Assim tem sido definida unipolaridade: "An unipolar system is one in which a single state controls a disproportionate share of the politically relevant resources of the system." Walt (2009), p. 91.
} 
More Opposed to the Unipole

More Supportive of the Unipole

\begin{tabular}{|c|c|c|c|c|c|}
\hline Hard & Soft & "Leash- & Neutrality & Bandwagoning & Regional \\
\hline Balancing & Balancing & Slipping" & & & Balancing \\
\hline
\end{tabular}

A respeito, chama a atenção o conceito de soft balancing. Walt indica que "instead of hard balancing, efforts to join forces to counter U.S. power or limit U.S. influence have generally taken the form of soft balancing." E continua: "[I]n the current era of U.S. dominance, therefore, soft balancing is the conscious coordination of diplomatic action in order to obtain outcomes contrary to U.S. preferences, outcomes that could not be gained if the balancers did not give each other some degree of mutual support. ${ }^{3418}$ Interessante notar que a literatura identifica soft balancing como um instrumento em geral utilizado por países de tamanho médio, visando a constranger iniciativas particulares dos EUA.

Outros tantos trabalhos se seguiram, cobrindo temas dos mais diversos (chances de conflitos armados entre países aliados; influência de alianças no comércio de bens; ${ }^{419}$ análise de questões de segurança na formação de alianças; ${ }^{420}$ confiabilidade de alianças em tempos de guerra), ${ }^{421}$ sem deixar de tratar da atualidade da teoria frente às mudanças geopolíticas ocorridas desde a década de 1980.

\section{F. Glenn H. Snyder: principal sistematização}

Certamente, o estudo mais compreensivo e sistemático acerca da formação e administração de alianças foi realizado por Glenn H. Snyder, em sua obra "Alliance Formation" (Snyder (1997)). Pela capacidade de sistematização, a obra de Snyder tem papel relevante nesta tese, pois incorpora o desenvolvimento da teoria de formação de alianças que a precedeu.

\footnotetext{
$418 \quad$ "Hard balancing usually focuses on the overall balance of power and seeks to assemble a countervailing coalition that will be strong enough to keep the dominant power in check, no matter what policies it decides to pursue. By contrast, soft balancing accepts the current balance of power but seeks to obtain better outcomes within it, by assembling countervailing coalitions designed to thwart or impede specific policies. (...) Instead of combining military forces or conducting joint operations, soft balancers combine their diplomatic assets in order to defend their interests. By definition, soft balancing seeks to limit the ability of the United States to impose its preferences on others." (Ibid.)

$419 \quad$ Gowa e Mansfield (2004).

$420 \quad$ Snyder (1984).

$421 \quad$ Leeds (2003).
} 


\section{Definição e Tipologia de Alianças}

Snyder define alianças como "formal associations of states for the use (or nonuse) of military force, in specified circumstances, against states outside their own membership". ${ }^{422}$ Logo se verifica que a utilização do termo "aliança" se restringe àquelas situações. Outras formas de alinhamentos entre diferentes países poderão ser designados por expressão de conceito não definido, como alinhamentos, arranjos ou coalizões.

O professor de relações internacionais de Chappel Hill então apresenta uma tipologia das alianças, com base em formas de diferenciação, resumidamente apresentada a seguir:

(i) Natureza: unilateral, bilateral ou multilateral;

a. Alianças unilaterais: se dão em geral na forma de garantias, pois apenas um dos membros assume um determinado compromisso (por exemplo, proteção ao aliado), sem qualquer assunção de compromisso por parte do outro;

b. Alianças bilaterais e multilaterais: são a maioria das alianças formadas, com cada membro assumindo alguma obrigação;

(ii) Força (strength): alianças iguais e desiguais. Diferenciam-se pelo equilíbrio de força (ou capacidades) entre seus membros, o que pode levar a um desequilíbrio de obrigações e expectativas;

(iii) Objetivo (purpose): alianças podem ser ofensivas, defensivas ou mistas. Dentro dessas categorias, pode-se incluir:

a. Pactos de neutralidade: em que as partes concordam em não se juntar a um ataque ao aliado (podendo ser tanto ofensivos quanto defensivos);

b. Pactos de não-agressão: em que as partes concordam em não atacar um ao outro (podendo ser tanto ofensivos quanto defensivos); ${ }^{423}$

\footnotetext{
$422 \quad$ Snyder (1997), p. 4. E prossegue: "Thus I take that an alliance, properly speaking, can be the result only of formal agreement of some sort that makes explicit the contingencies in which military cooperation will occur." (Ibid.)

423 "Typically, a weak country making a nonaggression pact with a powerful one will be defensively motivated. A strong country may use such a pact for offensive purposes - to lull a victim into complacency or discourage it from looking for allies. Stalin provides an example of mixed motives. By using a nonaggression pact with Hitler in 1939, he sought chiefly to avoid war by deflecting German aggressiveness westward, but
} 
(iv) Motivação (motive): dentro da categoria alianças defensivas, pode-se identificar motivos diferenciados, como:

a. Segurança contra ataque externo;

b. Aumento da segurança interna ou estabilidade política de um determinado país; $^{424}$

(v) Natureza da obrigação gerada pelo casus foederis: as alianças se diferenciarão pela definição da própria obrigação decorrente do fato ou evento (casus foederis) gerador da obrigação estatuída na aliança;

(vi) Grau de formalização: alianças poderão ser expressas por compromissos tácitos, verbais ou escritos (neste caso, podendo ser expressas por uma infinidade de documentos, como troca de notas, comunicados conjuntos, minutas, memorandos de entendimentos, tratados, entre outros). O termo "aliança" denota os acordos formalmente firmados entre ao menos dois países;

(vii) Duração: Snyder diferencia entre dois tipos, a saber:

a. Alianças de longa duração, ou seja, formadas para lidar com um determinado evento (casus foederis), que poderão ou não ocorrer durante a vigência do acordo; e

b. Coalizões ad hoc, ou seja, arranjos com um propósito específico, as quais, uma vez atingido aquele, se desfazem.

\section{O Contexto Sistêmico das Alianças}

O trabalho de Snyder tem nítida e declarada orientação neorrealista. ${ }^{425}$ Ao justificar tal alinhamento, Snyder situa a discussão da formação de alianças em um contexto sistêmico, com quatro entidades analíticas, a saber: Estrutura, Unidades, Relacionamentos e Interação. Ou seja, Snyder pressupõe que qualquer análise acerca da formação de alianças parta da definição dessas entidades analíticas.

he also made substantial offensive gains himself in occupying eastern Poland with Hitler's permission." (Ibid., p. 13).

424 "Alliance tends to legitimize an existing government and thus to discourage dissidents; it may even promise the ally's aid in suppressing internal disorder. (...) Example of using an alliance for control purposes are the U.S. employment of NATO to control West Germany, and German control over Austria by means of the alliance of 1879. Alliances may also function as cloaks for imperial domination, as the Soviets used the Warsaw Pact during the cold war." Ibid., p. 13.

$425 \quad$ Ibid., p. 20: "In the neorealist perspective, causal influences on behavior are found either in system structure or in the internal characteristics of states, although the theoretical focus in on the structural effects." 
Ao assim fazer, remete-se ao estudo de Kenneth N. Waltz e sua incansável busca por uma sistematização de uma teoria de relações internacionais (e, por conseguinte, do equilíbrio de poder e, por fim, da formação de alianças), por incorporar Estrutura e Unidades. A adição de Relacionamentos e Interação, no dizer de Snyder, faz com que se incorpore um aspecto processual à análise. ${ }^{426} \mathrm{E}$ é justamente nessa adição desse aspecto processual que Snyder contribui sobremaneira à teoria de formação de alianças, como exposto mais adiante.

No tocante à Estrutura, Snyder não difere da teoria até então desenvolvida. Em se tratando de um sistema internacional, classifica-o dentro de uma estrutura de anarquia (ou seja, sem a presença de um ente governamental que garanta a execução de contratos ou promova segurança coletiva, em contraste aos sistemas hierárquicos domésticos). ${ }^{427}$ Daí deriva, na melhor tradição sobre equilíbrio de poder, a necessidade de os países se aliarem para preservar ou aumentar seus interesses ou posições (ao que dá o nome de dilema da segurança - "security dilemma").

Outro aspecto determinante da Estrutura do sistema sob análise se perfaz na análise de sua polaridade, ou seja, quantos pólos uma determinada estrutura sistêmica contém. Snyder tampouco inova nesse tema, conceituando um pólo como uma "superpotência". Seguindo-se classificação oferecida por Stephen M. Walt, haverá unipolaridade quando uma determinada unidade reúna mais capacidades do que as demais reunidas; bipolaridade, quando a maioria das capacidades estiver concentrada nas mãos de duas unidades ("dois grandes poderes"); e multipolaridade, quando forem mais do que duas as grandes potências em um determinado sistema. ${ }^{428}$ A partir daí, Snyder acentua que a configuração de um sistema como unipolar, bipolar ou multipolar influencia as estratégias de formação de aliança.

\footnotetext{
$426 \quad$ Ibid., p. 16 : "Alliances cannot be understood apart from their context in the international system. The system provides much of the motive for allying, and the nature of alliances varies with characteristics of the system. Alliance formation and maintenance are basic systemic processes. The systemic context of alliances may be described in terms of four analytic entities: structure, relationships, interaction, and units. Relationships and interaction are aspects of systemic process: system structure and acting units provide 'external' and 'internal' inputs into the process. The following analysis is based on the 'neorealist' theory of international politics, but it expands that theory by introducing elements of process.".

$427 \quad$ Ibid., p. 17.

$428 \quad$ Walt (2009)
} 
Por exemplo, em um sistema bipolar, alinhamentos decorrem basicamente de tal estrutura. Como as superpotências serão sempre rivais, na medida em que não há outro país que possa equilibrar essa relação. Assim, o relacionamento entre tais superpotências será sempre de competição, na medida em que o outro constitui a única ameaça à sobrevivência de um. O alinhamento das nações mais fracas poderá se dar de maneira expressa, tácita ou mediante uma declaração de neutralidade, caso em que, todavia, possivelmente restará sob a proteção de uma das duas potencias. As causas de alinhamento poderão ser várias, mas incluem principalmente um alinhamento por coerção, proteção ou por uma análise comparativa entre o potencial de ameaça ou de suporte de cada pólo. ${ }^{429}$

Em um sistema multipolar, por sua vez, não existe uma determinação a priori das possibilidades de alinhamento decorrentes da estrutura. Pelo contrário, Snyder indica que, dentro de uma estrutura multipolar, as possibilidades se avolumam, assemelhando-se a um jogo de $N$-pessoas ( $N$-person game), ou seja, um jogo de vários jogadores, dentro da matriz de Dilema dos Prisioneiros (teoria dos jogos). ${ }^{430}$ Nesse contexto, cada país teria duas opções: buscar aliados ou permanecer neutro. Assumindo-se um equilíbrio de capacidades entre as unidades, poder-se-ia chegar a um equilíbrio de geral abstenção. Todavia, o risco de não alinhamento pode sujeitar uma unidade que não tenha se aliado ao domínio de outras que tenham (dado o aumento conjunto de capacidades). Logo, a incerteza do abandono (abandonement) pode impulsionar a formação de alianças, nem que seja para evitar que uma determinada unidade se alie com outra, a constituir uma ameaça não desejável. ${ }^{431}$ Uma vez que uma coalizão se forme, uma contra-coalizão se formará, revelando duas alianças rivais. Esse resultado é pior do que uma situação de abstenção geral, na medida em que todas as unidades tiveram de incorrer em custos e ônus para

429 Aqui, a comparação com o período da Guerra Fria entre EUA e a União Soviética é inevitável e Snyder a traz como ilustração: "Alignment of the lesser states in a bipolar system is only partially determined by structure. Some may be coerced into alliance with a superpower, and such coercion may be structurally motivated, as in the case of Soviet coercion of the Eastern European countries during the cold war. Others, such as the Western European states, will be so obviously threatened by one superpower, for geographic or other reasons, that they will turn to the other for protection. Still others will tend to ally with the local rivals, or the most rewarding financially - or they will not ally with either superpower. Nonaligned states, however, will be under the tacit protection of one or the other superpower. Alignments of the lesser states with each other will be affected by the degree of perceived threat from a superpower. Thus the common threat from the Soviet Union ruled out alignments by Western European countries against one another during the cold war, while the Middle Eastern states, feeling less threat from the Soviet Union, were freer to align and realign according to local conflicts and interests." Snyder 1997, p. 19.

$430 \quad$ A aplicação da teoria dos jogos na análise de relações internacionais já se tornou uma ferramenta comum e corriqueira, como se pode denotar de diversos textos mencionados neste trabalho. No Brasil, vide Calliari (2003), aplicando-a no contexto do SSC da OMC.

$431 \quad$ Snyder (1997), p. 19. Vide também, na parte relativa ao jogo de $N$-pessoas, Ibid., p. 462. 
formar as coalizões, com pouco aprimoramento no nível de segurança. A incerteza do abandono pode também levar a formulações de alianças mais ou menos rígidas, para assegurar a permanência da unidade na aliança (lock-in). ${ }^{432}$

No tocante aos Relacionamentos, Snyder os classifica como a situação de contexto de um determinado comportamento entre duas unidades. Snyder esclarece que os Relacionamentos se diferenciam da Estrutura (por não se perfazerem em conceitos sistêmicos) e da Interação (por definirem o contexto da inter-relação, mas não se constituírem nela). Nesse sentido, os componentes do Relacionamento seriam causas próximas da conduta de uma unidade, constrangidas por causas remotas, como a Estrutura, embora operando independentemente. A sua presença encerra a trajetória causal entre os Atributos das Unidades (preferências, percepções, políticas) e a Interação, em que seriam intermediados por Estrutura e Relacionamentos. ${ }^{433}$

Snyder sustenta que os Relacionamentos seriam compostos por alinhamentos $e$ alianças; interesses comuns ou conflitantes; capacidades; e interdependência, a seguir descritos:

Alinhamentos $\boldsymbol{e}$ Alianças: são variáveis preeminentes entre as variáveis relacionais, pois marcam as linhas de amizade ou inimizade, determinando o tipo de relacionamento entre determinadas unidades (adversário, aliado ou indiferente). Encerram expectativas quanto ao tipo de conduta por parte de outras unidades, dentro de futuras interações (oposição, apoio, neutralidade). ${ }^{434}$

\footnotetext{
432 Snyder não elabora sobre o sistema de incentivos para formação de alianças em um sistema unipolar.

433 Ibid., pp. 20-21.

Alianças não constituem Estrutura, pois não são nem o princípio constitutivo do sistema (anarquia), nem a distribuição de recursos entre estados (polaridade). Em um sistema multilateral, esclarece Snyder, as alianças teriam efeitos quase estruturais: "Since commitments have some force, and since states, once allied, become somewhat dependent on each other, alliances in a multipolar system might be said to have quasistructural effects. They identify friends and foes more clearly, and they aggregate power among friends. Thus they concentrate power in the system and focus insecurities and dependencies between particular states and groups of states. These effects are not greatly dissimilar to those that follow directly from structure in a bipolar system. The difference, of course, is that in a multipolar system the identifications and power concentrations are considered provisional and temporary; they turn on political declarations between approximate equals, not on unequal distributions of power amont states. Since these are large and significant differences, alliances are best considered relationships that are affected by structure and that may have quasi-structural effects but are not constitutive of structure." (Ibid., p. 22).
} 
Interesses: para Snyder, a incorporação dos interesses na análise da interação entre determinadas unidades enriquece a teoria neorrealista, por permitir refinar explicações sobre eventuais alinhamentos decorrentes do equilíbrio de poder (ou de ameaças). Ou seja, os interesses poderão ajudar a indicar a velocidade de formação de uma determinada aliança - ou se tal aliança afinal se formará (por exemplo, no caso de o país fiel da balança ["holder of the balance"] ${ }^{435}$ deter interesses conflitantes com o outro).

Nesse sentido, a incorporação de interesses na análise potencializa a validade do axioma Waltziano de que a flexibilidade de alinhamento em um sistema multilateral induz a uma rigidez de política, e vice-versa (ou seja, de que a existência de alternativas para uma unidade leva a outra unidade aliada a procurar atender seus interesses de maneira customizada). ${ }^{436}$

Ao tratar dos interesses, Snyder os distingue dos objetivos concretos de uma determinada unidade, para valorá-los dentro de determinadas métricas das relações internacionais, a saber: (i) valores intrínsecos, considerados como valores-fim, ou seja, valorados por si próprios, não por seus efeitos sobre outros valores, podendo incluir valores econômicos, morais, entre outros (incluem, por exemplo, políticas de proteção a nacionais no exterior, combate ao tráfico de drogas, entre outros); (ii) valores estratégicos ou reputacionais, considerados como instrumentais, já que medidos não por seu valor, mas por sua contribuição na proteção ou promoção de outros interesses no futuro (incluem, por exemplo, o controle territorial do espaço, dos mares ou de determinada fonte de energia, como forma de contribuir ao poderio nacional ou à segurança). ${ }^{437}$

Snyder ainda trata das dimensões dos interesses, a saber: (a) direção (conflituoso ou comum); e (b) intensidade (o grau de conflito ou de comunalidade), composta pelo escopo e profundidade da comunalidade ou conflito dos interesses.

Por fim, Snyder ainda trata do grau de especificidade dos interesses, que podem ser caracterizados como interesses sistêmicos ou específicos. Tal caracterização pode influir na capacidade de resolução do conflito (interesses gerais, por serem sistêmicos, podem ser

\footnotetext{
$435 \quad$ Waltz (2010).

$436 \quad$ Snyder claramente adota esse axioma Waltziano em sua análise. Vide Snyder (1997), p. 23.

437 Snyder ainda apresenta digressão sobre os interesses estratégicos, bem como diferencia interesses gerais ou particulares (Ibid., pp. 24-27). Tal discussão será retomada quando necessário.
} 
mais difíceis de conciliar) e no tempo de duração de uma aliança (coalizões baseadas em interesses específicos tendem a durar mais por mudarem com menor frequência, diferentemente dos interesses gerais no âmbito de um sistema multipolar). ${ }^{438}$

Em resumo, tem-se que os interesses possam ser classificados por: (i) valores subjacentes: referentes a valores intrínsecos ou estratégicos; (ii) direção: conflitantes ou comuns; (iii) intensidade: intensos, moderados ou leves; (iv) especificidade: sistêmicos ou específicos.

Capacidades: nesse ponto, Snyder evoca a definição de capacidades, há tempos explorada na tradição realista (ou seja, a quantidade de recursos controlados pelas unidades). Todavia, Snyder sugere que tal definição deva focar no potencial de resultado de tais recursos, ou seja, o que a unidade consegue atingir com tais recursos. Ao assim sugerir, Snyder indica que capacidades se constituem como um elo entre a estrutura do sistema e a interação entre as unidades. ${ }^{439}$

Nesse sentido, dependendo da configuração das alianças, com determinados recursos uma unidade conseguirá derrotar um adversário - mas não outros. Tal redefinição permite realçar a importância que a detenção de determinados ativos possa ter para atingir determinados objetivos. Nesse ponto, Snyder invoca o conceito de especificidade de ativos (asset specificity), tão caro dentro da teoria de custos de transação, desenvolvida por Oliver Williamson, ${ }^{440}$ entre outros, ou seja, de que a valoração de um determinado ativo varia de acordo com a unidade que dele fará uso, insculpindo na teoria a noção de capacidade relativa.

Aliança-Dependência: a dependência a uma determinada aliança se perfaz no grau de dano provocado pela deserção total ou parcial (não-cumprimento de obrigações) da aliança por um aliado. De forma mais elaborada, Snyder a define como sendo "uma função do grau de ameaça oferecido por um adversário, a extensão da contribuição do aliado em deter ou defender contra a ameaça e a disponibilidade ou custo de meios alternativos para

\begin{tabular}{ll}
\hline 438 & Ibid., pp. 24-27. \\
439 & Ibid., p. 28. \\
440 & Williamson (1985)
\end{tabular}


neutralizar a ameaça". 441 Nessa linha, o grau de dependência dentro da coalizão determinará o seu de grau de coesão ou fragilidade: os aliados tenderão a ser mais dependentes um do outro quanto maior for a ameaça enfrentada, quanto mais um depender do outro para fazer frente à ameaça e quão menos atraentes ou disponíveis forem as alternativas. Quando os aliados forem assimetricamente dependentes, o menos dependente, em geral, exercerá a maior influência. Inversamente, quando a aliança for simétrica, provavelmente será difícil exercer influência sobre o outro. Por fim, quando for elevada a dependência mútua, a aliança será coesa; quando baixa, a aliança será frágil. ${ }^{442}$

Uma das significativas contribuições de Glenn H. Snyder se perfaz na adição dos Relacionamentos na matriz neorrealista, de que se deriva que o comportamento das unidades - nos dizeres de Waltz - não será apenas influenciado pela Estrutura do sistema, mas também por outros fatores, como exposto por Snyder. Trata-se de uma evolução do quanto defendido por Waltz. Como Snyder ressalta: "considering these factors permits finer-grained predictions and explanations that are possible from structural reasoning alone." 443 Com efeito, Snyder sustenta que o comportamento das unidades deriva dos Relacionamentos, na medida em que interesses se transformem em conflitos, forças em capacidades e vulnerabilidade em interdependência. ${ }^{444}$

Ao retirar os atributos das unidades do isolamento, Snyder acrescenta uma dimensão relacional à formação de alianças, ao mesmo tempo em que apresenta uma metodologia sistemática para tal estudo. Nesse ponto, Snyder é critico do neorrealismo, por não oferecer uma resposta completa sobre a formação de alianças, sustentando que "alinhamento" constitui no principal elo faltante da análise entre, de um lado, Estrutura e Atributos das unidades, e, do outro, Interação e Comportamento. ${ }^{445}$

\footnotetext{
$441 \quad$ Snyder (1997), p. 31.

442 Ibid., p. 31.

$443 \quad$ Ibid., p. 32.

$444 \quad$ "The internal characteristics of states also work their effects through relationships. Relationships form at the intersection of the attributes of states - where interests become conflicts, forces become capabilities, and vulnerabilities become interdependence. It is the assessment of these intersections-how much conflict exists between my interests and my opponent's interests on this issue? Who would win a war between us at what cost? Do I need the help of my ally and will it help? - that bears directly on a state's decisions and behavior, not its own 'unit attributes' in isolation." (Ibid., p. 32).

445 "Contrary to the general belief, neorealism does not say much about what causes states in a multipolar system to identify each other as friends or enemies or about the consequences of such identification. If we have a theoretical knowledge of the dynamics of alliance formation and alliance management, and of how these dynamics are related to the logic of structure, we can predict and explain far more than we can from structure alone." (Ibid., p. 32).
} 
Ao final, Snyder trata da Interação. Snyder crê que a aproximação do realismo estruturalista e a teoria da barganha permitirá uma compreensão mais completa do processo de formação de alianças. Nesse diapasão, Snyder classifica interação como a principal variável do esquema teórico em questão, definindo-a como "o processo pelo qual alinhamentos, interesses, capacidades, e dependência são traduzidos em resultados", podendo tomar diversas formas, como "guerras, crises, corridas armamentistas, e acordos de alianças, além de visitas ou encontros diplomáticos".

Snyder então apresenta esquema que resume as possibilidades de interação entre unidades, partindo-se da premissa de dois tipos básicos de relacionamento (no caso, em questões de segurança): alinhamento ou adversarial. Considera, ainda, que em cada relacionamento será possível identificar um "jogo" iterativo, a ser "jogado" em três arenas: preparação, diplomacia ${ }^{446}$ e ação militar, envolvendo interações entre aliados e adversários, em situações mais próximas ao conflito ou à cooperação. Assim, Snyder propõe a seguinte matriz, que permite determinar payoffs de cada arena de interação (total de seis em cada jogo) sendo que a percepção de tais payoffs determina as escolhas de interação:

\begin{tabular}{cc|c|c|c|}
\hline Jogo Adversarial & Preparação & Diplomacia & Ação \\
\cline { 2 - 5 } & Conflito & $\begin{array}{c}\text { Corrida } \\
\text { armamentista }\end{array}$ & Ameaças de força & Guerra \\
\hline Jogo Aliança & Cooperação & $\begin{array}{c}\text { Compartilhamento } \\
\text { de onnus/ } \\
\text { planejamento } \\
\text { conjunto } \\
\text { Comportamento } \\
\text { oportunista } \\
\text { (free ride) }\end{array}$ & Concessões & $\begin{array}{c}\text { Limitação ou } \\
\text { término da guerra }\end{array}$ \\
\hline
\end{tabular}

Evoluindo a partir daí, Glenn Snyder conclui com o conceito de barganha, focalizando as interações possíveis dentro de um jogo adversarial ou de um jogo de aliança. Isto é, Snyder explica que a análise da interação de aliados em uma aliança - seja para tratar do controle de armas, seja no tocante a uma resolução terminando uma guerra,

446 No caso, entendida como todas as comunicações verbais entre estados, incluindo formação de alianças ou negociações intra-alianças, bem como toda comunicação ou negociação entre adversários. (Ibid., p. 34). 
podendo se perfazer também nos termos iniciais de uma aliança ou as contribuições devidas por cada aliado - pode ser feita a partir de uma matriz simples de jogo entre dois jogadores (na estrutura de Dilema dos Prisioneiros). De fato, como sustenta Snyder, o poder de barganha relativo a adversários dependerá das percepções das capacidades comparativas e da intensidade relativa de seus interesses conflitantes. ${ }^{447}$ No caso de aliados, o poder de barganha derivará das percepções sobre sua dependência relativa, compromissos e intensidade de interesses sobre o objeto da barganha. Reconhecendo a dificuldade de observar tais fatores relacionais, Snyder indica que a percepção deles será uma proxy do comportamento do outro. Nesse sentido, entra o papel da comunicação entre os agentes, na medida em que modificam as percepções desses relacionamentos e do comportamento de si próprio, de maneira a aprimorar o próprio poder de barganha.

Com efeito, no tocante à comunicação, ressalta a importância da comunicação verbal como atividade distintiva da arena diplomática. Entre aliados, o protótipo da cooperação verbal é a "promessa"; por sua vez, entre adversários, o protótipo do conflito verbal é a "ameaça". A credibilidade de ambos reside nos interesses percebidos subjacentes a eles. Percepções, por sua vez, prossegue Snyder, acerca do interesse de outros traduzem-se em expectativas futuras sobre o comportamento futuro, ou seja, "expectativa sobre apoio ou hostilidade constituem o padrão de alinhamento discutido acima". ${ }^{448}$ Nesse sentido, tanto as promessas quanto as ameaças se perfariam na comunicação que visa a fortalecer, enfraquecer ou mesmo mudar as expectativas existentes. Cada agente faz isso condicionando seu comportamento no comportamento do outro, atribuindo valor caso a comunicação seja perdida. Cada agente procura agir de forma a induzir o comportamento do outro na direção da cooperação, completa Snyder, ressaltando que aliados fazem isso por meio de "recompensas", ao passo que adversários o fazem por meio de "punição". Como resultado, cada mecanismo reforça o relacionamento correspondente: promessas de aliança aumentam a solidariedade entre aliados, enquanto o escalonamento de ameaças aumenta a tensão entre adversários. ${ }^{449}$ Importa ressaltar diferença na estrutura de tais sistemas, na medida em que o cumprimento de uma promessa é um passo mais natural do que a aplicação de sanção, anteriormente ameaçada, até porque o não cumprimento de uma obrigação contratada leva a um problema de esvaziamento da 
própria aliança, em prejuízo de ambos. A aplicação de uma sanção, por sua vez, mesmo que objeto de ameaça anterior, deverá passar no teste do interesse próprio (self-interest) do estado ameaçador. Nesse contexto do reconhecimento de uma aliança como um relacionamento, criado por diversas interações, Snyder propõe a matriz de jogo entre dois jogadores, mencionada acima.

a. Jogo Adversarial

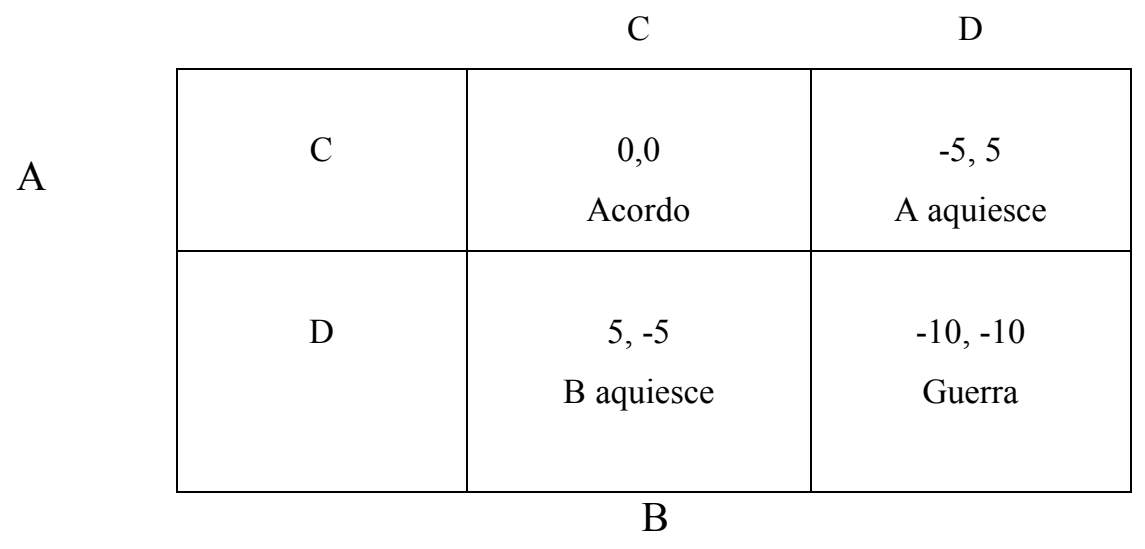

b. Jogo de Aliança

$\mathrm{C}$

$\mathrm{D}$

A

\begin{tabular}{|c|c|c|}
\hline C & $\begin{array}{c}3,3 \\
\text { Acordo }\end{array}$ & $\begin{array}{c}1,5 \\
\text { A aceita termos } \\
\text { de B }\end{array}$ \\
\hline D & $\begin{array}{c}5,1 \\
\text { B aceita termos } \\
\text { de A }\end{array}$ & $\begin{array}{c}\text { Nenhum acordo, } \\
\text { aliança desfeita }\end{array}$ \\
\hline
\end{tabular}

Cada matriz reflete as possibilidades de resultado nas interações mantidas entre as unidades. Na célula DD (matriz “a”), pode-se identificar o payoff atribuído a uma situação de crise e instalação de guerra. Da mesma forma, os payoffs das células CD e DC referemse ao próprio objeto da barganha, indicando a diferença entre os payoffs a intensidade do 
conflito de interesses estabelecido. Afinal, os números na célula CC indicam o payoff de eventual acordo entre os adversários.

Em relação à matriz "b", concernente a uma possível aliança entre as unidades A e B: a célula DD indica os custos de um rompimento da aliança, sendo uma função da relação de sua interdependência; as células CD e DC ilustram a extensão do conflito entre as partes no tocante ao objeto da barganha (entrar em aliança ou permanecer desalinhados, por exemplo) e; por fim, a célula CC mostra os valores para uma celebração de acordo.

Snyder explica que, em cada uma das possibilidades de resultados nas matrizes, deve-se incorporar nos payoffs futuros payoffs de jogadas futuras (trazidos a valor presente), bem como qualquer chance de modificação na possibilidade de futuras jogadas ocorrerem. Isso faz com que se considere que essa primeira matriz constitui a primeira de muitas rodadas, dentro de um jogo iterativo, com cada rodada mudando o contexto de relacionamento da rodada subsequente.

Com isso, Snyder conclui que a matriz apresentada incorpora os quatro elementos sistêmicos de uma teoria de formação de alianças: Estrutura, Unidades (Atributos), Relacionamentos, Interação e Resultados, sendo que os três últimos aparecem na matriz explicitamente e os dois primeiros nos cálculos dos payoffs. ${ }^{450}$ Isso permite integrar em apenas um exercício tanto estrutura quanto efeitos de processo. Como conclui Snyder, "[ $\mathrm{t}]$ he connection between relationships and interaction clearly runs both ways. Not only do relationships shape interaction choices; interactions may also change relationships. Thus an alliance negotiation changes alignments, an arms race changes capabilities, a crisis may change the level of conflict between adversaries and the degree of interdependence between allies, and a war may change all these things". 451

$450 \quad$ "Thus the flexibility of alliances in multipolarity appears as relatively high payoffs in the DD cell of Figure 1-3b, reflecting the existence of alternatives if a present alliance breaks up or an attempt at alliance formation fails. Relatively equal payoffs in the DD cell show the symmetrical dependence typical of multipolarity; the asymmetrical dependence in alliances in a bipolar system would appear as unequal DD payoffs." (Ibid., p. 38).

451 Ibid., pp. 38-39. 


\section{A Formação das Alianças}

Segundo Glenn Snyder, a decisão sobre formar determinada aliança decorre basicamente de uma análise de custo-benefício. Tal análise se perfaz em um exercício de determinação do valor da aliança $(S)$, o qual se baseia em vários elementos, adiante especificados. Com a definição do valor da aliança (custo x benefício), Snyder sustenta que a formação de alianças dependerá de uma análise da estrutura de incentivos a ela relacionada, considerando aspectos sistêmicos (estrutura do sistema internacional) e nãosistêmicos (diferenças de capacidades e conflitos de interesses). Então, Snyder avança com a aplicação da barganha, dentro de uma matriz de teoria do jogos, como forma de analisar o processo de negociação dos termos da aliança. Desse sumário, logo se vê que a teoria de formação de alianças, como sistematizada por Glenn Snyder, constrói-se sobre as bases das teorias de bens coletivos, teoria da coalizão, teoria dos jogos e teoria da barganha.

Segundo Snyder, o cálculo do valor da aliança dependeria da identificação de seus principais benefícios e custos. Snyder então aponta os princípios benefícios de uma aliança, a saber:

1. Elevação da dissuasão de ataque contra si;

2. Elevação da capacidade de defesa contra um ataque contra si;

a) Maior probabilidade de ajuda por parte do estado aliado;

b) Maior probabilidade de sucesso da defesa quando a ajuda do aliado se efetive;

3. Elevação da dissuasão de ataque contra o aliado;

4. Preclusão de aliança ou alinhamento entre o aliado e seu oponente (além de prender o aliado, uma aliança diminui a necessidade de o aliado procurar outro aliado);

5. Eliminação da possibilidade de ataque pelo aliado;

6. Elevação no controle ou influência sobre o estado aliado.

Por sua vez, os principais custos de se alinhar seriam:

1. Risco de se ver obrigado a ajudar o aliado, quando a abstenção seria preferível, na ausência do compromisso; 
2. Risco de aprisionamento (entrapment) em uma guerra em razão de um comportamento indesejável (irresponsabilidade, agressividade, provocador) do aliado;

3. Risco de formação de uma contra-aliança;

4. Eliminação de alternativas de alinhamento (eliminar as opções de um parceiro é um benefício, mas eliminar as suas próprias é um custo);

5. Restrições gerais na liberdade de ação e necessidade de coordenar políticas com o aliado. $^{452}$

Tal lista identifica os benefícios e custos centrais de uma aliança, sem todavia determinar sua magnitude. Nesse sentido, a magnitude dos benefícios e custos de aliança, segundo Snyder, é definida em termos dos benefícios de segurança de cada parte envolvida, sendo determinado por três fatores: (i) a necessidade da aliança (em função da ameaça posta pelo adversário em questão); (ii) o grau de satisfação pelo aliado pretendido de atender tal necessidade (em termos de capacidades e confiabilidade no cumprimento de suas obrigações na aliança, variando, portanto, de acordo com a diversidade de aliados pretendidos); e (iii) os termos reais do contrato da aliança. ${ }^{453}$ No tocante a esse último ponto, há que se averiguar a situação pré-aliança, para verificar se os aliados já se prontificariam a dar suporte ao outro, mesmo na ausência de aliança (por exemplo, em decorrência de situações estruturais) ou mesmo a existência de conflitos entre aliados prospectivos, que os impediriam de se aliarem - ou tornariam um alinhamento mais difícil. A partir dessas premissas, Snyder apresenta uma fórmula representando cada uma das variáveis possíveis no cálculo do valor da aliança para cada aliado (portanto, precisaria ser aplicada duas vezes), sendo que a diferença entre os valores $(S)$ apurados constituiria os ganhos líquidos da aliança. ${ }^{454}$

\footnotetext{
$452 \quad$ Ibid., pp. 44-45.

453 Ibid., p. 45. opponent:

$S=$ security-autonomy level

$\mathrm{Pa}=$ probability of being attacked

$1-P a=$ probability of not being attacked

$P h=$ probability of being helped by the ally (the ally's "loyalty”)

$1-P h=$ probability of not being helped by the ally
}

$454 \quad$ Não é o caso de se ater aos detalhamentos da fórmula proposta por Snyder, já que o próprio Snyder indica não defender sua aplicação empírica (na realidade, Snyder aponta uma série de incompletudes na fórmula em questão), sendo entretanto interessante refleti-la neste texto, pelo seu valor didático:

"Consider the following notation, with respect to a potential attack on one's own state by a given (state) 
Com isso, Snyder avança para analisar os incentivos de natureza sistêmica e os de natureza não-sistêmica relativos à formação de uma aliança.

Ao tratar dos incentivos sistêmicos, Snyder remete novamente à teoria de equilíbrio de poder, com suas premissas, do ponto de vista estrutural, de sistema anárquico e de multipolaridade. Nessa linha, repisa a noção de que é interesse de cada unidade impedir qualquer outra unidade de dominar o sistema (ou seja, de ganhar controle de mais da metade dos recursos militares do sistema). Confronta a teoria de equilíbrio de poder com a teoria de bens coletivos, a qual aponta a existência de incentivos poderosos para que cada unidade não aja contra um agressor, na presunção de que outros deverão fazê-lo (de maneira que a unidade inativa necessariamente se beneficiará sem ter com nada contribuído) ou mesmo do receio de que, agindo, outros não o façam, beneficiando-se do

Pvh = probability of victory with the ally's help

$P d h=$ probability of defeat despite the ally's help

$P v=$ probability of victory without the ally's help

$P d=$ probability of defeat when the ally does not help

$V=$ value of victory

$D=$ value of defeat

Ch $=$ cost of war with the ally's help

$C=$ cost of war when the ally does not help

With respect to potential attack on the prospective ally:

Paa = probability of attack on the ally

$1-$ Paa = probability of no attack on the ally

Pha = probability of oneself aiding the ally

$1-$ Pha $=$ probability of oneself not aiding the ally

Pvha = probability of victory when one aids the ally

Pdha = probability of defeat when one aids the ally

$P v a=$ probability of the ally's victory without one's help

$P d a=$ probability of the ally's defeat when one does not help

$\mathrm{Va}=$ one's own value of successful defense of the ally

$\mathrm{Da}=$ loss to oneself when the ally is defeated

Cha $=$ cost of aiding the ally

$\mathrm{Ca}=$ cost of not aiding the ally

Then

$S=\{[P a(P h)(P v h)(V+C h)]+[P a(P h)(P d h)(D+C h)]+[P a(1-P h)(P v)(V+C)+[(P a$ $(1-P h)(P d)(D+C)]+[1-P a)(V)]\}$

minus

$\{[$ Paa $($ Pha $)(P v h a)(V a+C h a)+[P a a(P h a)(P d h a)(D a+C h a)+[P a a(1-P h a)(P v a)(V a+C a)]+[P a a 1-$ $P h a)(P d a)(D a+C a)]+[(1-P a a)(V a)]\}$

This equation would have to be applied twice, once to find the state's security-autonomy level before alliance (S1) and again to estimate that level after allying (S2). The difference between the two applications is the net gain from the alliance, the alliance's security-autonomy value." 
bem coletivo (no caso, segurança), sem com nada contribuir (problema do free-rider). ${ }^{455}$ Snyder resolve o dilema entre tais teorias ao comparar os ganhos com o free ride com os custos da inação a cada tentativa (rodada) por parte do oponente de dominar mais da metade dos recursos disponíveis. Em um continuum, uma ação resistente coletiva poderia ser prevista quando o oponente estiver no limiar de conseguir tal objetivo. ${ }^{456}$ A formação de uma aliança contribuiria para reduzir o problema dos bens coletivos, na medida em que geraria interesse na parte dos aliados de manter seu compromisso de defender o aliado, seja por um interesse estratégico gerador da própria aliança, seja para provar sua confiabilidade (interesse reputacional).

Quanto aos incentivos não-sistêmicos, sobressaem-se as diferenças de capacidades e os interesses comuns ou conflitantes entre determinados estados, como anteriormente explorados.

Aqui reside uma das contribuições significativas de Snyder: a possibilidade de analisar a formação de alianças a partir das diferenças de capacidades. Tomando-se uma situação entre três unidades, cada qual com capacidades diferentes, pode-se concluir, a partir de uma análise com base na teoria da barganha, os possíveis resultados de tais interações, considerando-se apenas uma estrutura anárquica, com três unidades com diferentes capacidades e a premissa de que as unidades procurarão formar a "menor coalizão vencedora", em respeito ao "princípio do tamanho"457 (ou seja, uma coalizão com o mínimo de participantes possível que permita reunir mais do que - mas o mais próximo de - metade dos recursos disponíveis), de forma a impedir os outros dois de se aglutinarem. Para construção do modelo, Snyder considerou os três benefícios básicos da formação de uma aliança: dissuasão, defesa e preclusão, atribuindo a cada qual um valor (no caso, 20 unidades de segurança), com o que a formação de uma aliança geraria benefícios de segurança (adicionando-se 20 unidades) e também excluiria a possibilidade de o oponente se aliar ao aliado (pois as capacidades do aliado seriam redirecionadas para o oponente, adicionando-lhe 20 unidades).

\footnotetext{
$455 \quad$ Ibid., pp. 50-51.

456 Snyder ressalva que tal comportamento se dava antes da era nuclear (Ibid., pp. 50-51).

457 Aqui, Snyder se apóia nos estudos de William A. Gamson (1961), o qual, por sua vez, se baseou em William Riker (que cunhou a expressão "size's principle", ao analisar coalizões entre partidos politicos), embora seja evidente a referência aos trabalhos de Olson e Zeckhauser (1966) e de Russett (1968). Snyder (1997), p. 55, n. 11: "Each party seeks to join 'that minimal winning coalition with total resources closest to the decision point', that is, with more than, but closest to, 50 percent of the total resources in the triad."
} 
Snyder então explora quatro situações envolvendo as três unidades, diferenciandoas quanto à detenção de capacidades: (i) as três unidades têm igualdade de capacidades; (ii) há duas unidades fracas e uma forte; (iii) há duas unidades fortes e uma fraca; e (iv) as três unidades têm capacidades diferentes.

Os Quadros 1 a 4 adiante resumem as quatro situações, indicando os ganhos de cada possibilidade de aliança e os incentivos existentes para tais alinhamentos: 


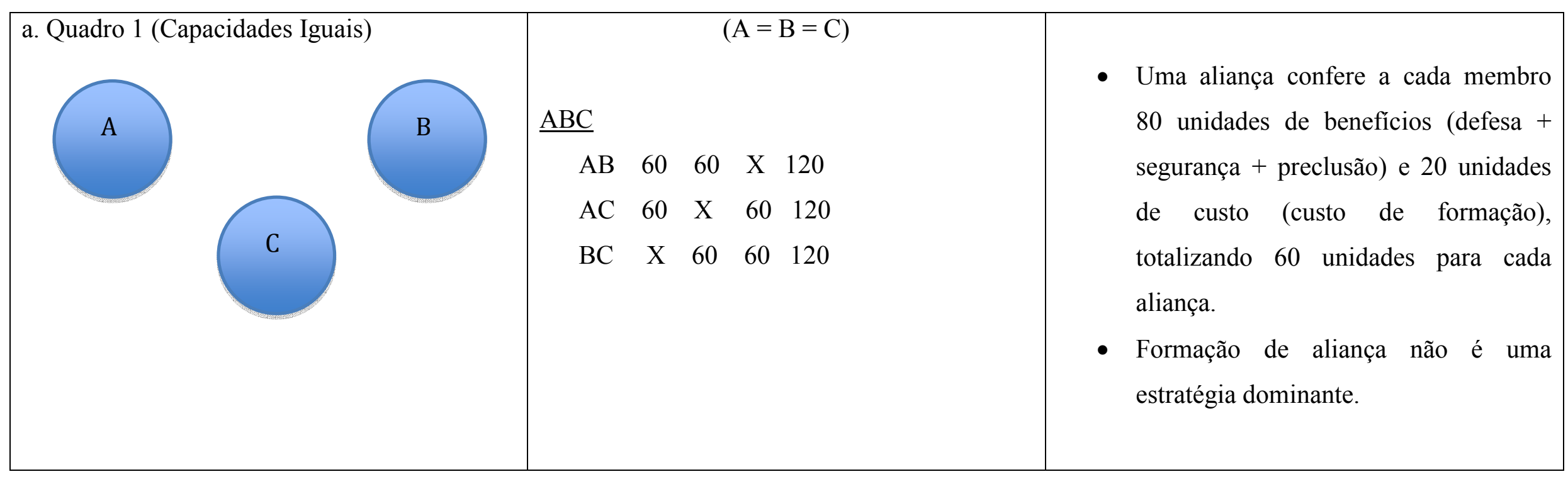




\begin{tabular}{|c|c|c|}
\hline b. Quadro 2 (Dois fracos, um forte) & \begin{tabular}{rccccc}
\multicolumn{8}{c}{$(\mathrm{A}>\mathrm{B}=\mathrm{C} ; \mathrm{A}<\mathrm{B}+\mathrm{C})$} \\
$\underline{\mathrm{ABC}}$ \\
$\mathrm{AB}$ & 0 & 60 & $\mathrm{X}$ & 60 \\
$\mathrm{AC}$ & 0 & $\mathrm{X}$ & 60 & 60 \\
$\mathrm{BC}$ & $\mathrm{X}$ & 80 & 80 & 160
\end{tabular} & $\begin{array}{l}\text { - Mesmo na ausência de alianças, B e C } \\
\text { defender-se-ão entre si, no caso de } \\
\text { ataque de A. Isso reduz os custos da } \\
\text { aliança. } \\
\text { - A defenderá tanto B quanto C, caso } \\
\text { necessário. } \\
\text { - B e C não têm qualquer interesse em } \\
\text { defender A, pois este tem capacidade } \\
\text { para se defender sozinho. } \\
\text { A se aliaria a B ou C apenas por } \\
\text { preclusão (excluir a formação BC). } \\
\text { Mas esse ganho seria sobrepujado pelo } \\
\text { custo de socorrer o aliado, quando } \\
\text { poderia socorrer o mais enfraquecido, } \\
\text { em caso de combate entre B e C. } \\
\text { BC é a formação mais valiosa, por } \\
\text { possibilitar benefícios de dissuasão } \\
\text { (em relação a A), defesa (em relação a } \\
\text { A) e preclusão (por evitar que A se } \\
\text { forme com B ou C), com custos de } \\
\text { formação reduzidos. }\end{array}$ \\
\hline
\end{tabular}




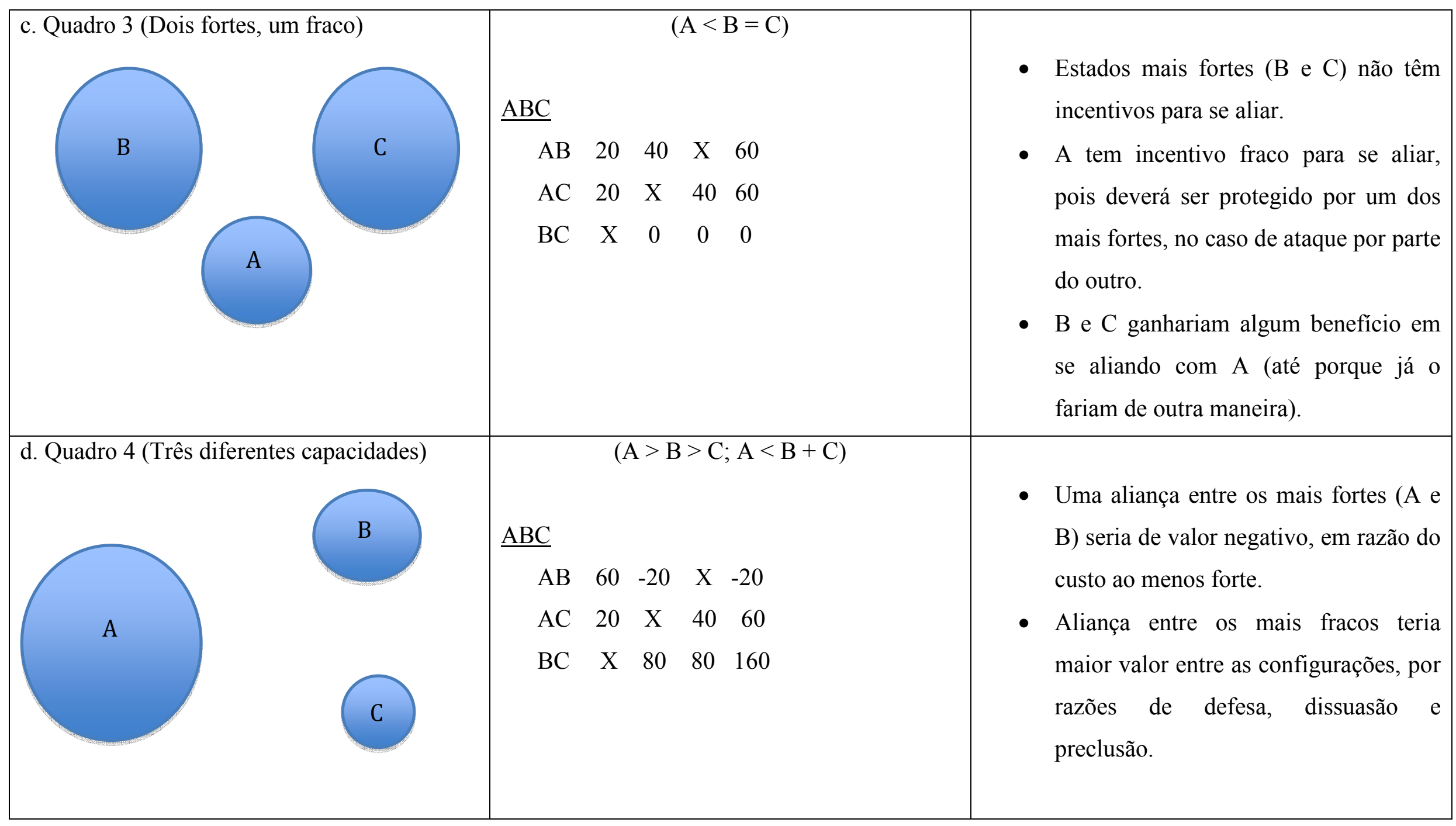


Considerando-se os resultados obtidos acima, Snyder deflui o que segue:

1. Desigualdade de capacidades gera algum grau de alinhamento, independente de alianças formais (interesse estratégico de defender ou não defender determinadas unidades). Estados mais fracos se defenderão uns aos outros e terão a expectativa de serem defendidos por estados fortes contra outros fortes;

2. Alianças formais geram tanto benefícios quanto custos e isso modifica expectativas de alinhamento. Custos e benefícios variarão de acordo com as condições préaliança;

3. Alianças compatíveis com interesses estratégicos valem mais do que as que não o forem, principalmente porque custam menos;

4. As alianças mais valiosas são aquelas entre países fracos ameaçados por fortes;

5. As alianças menos valiosas são aquelas entre dois países fortes contra um fraco;

6. Quando um país forte se alia a um fraco, quem mais se beneficia é o país fraco, se o oponente for fraco; de outra parte, o país forte se beneficiará mais se o oponente for forte. ${ }^{458}$

No tocante a interesses comuns ou conflitantes, Snyder pontua que sua existência no período pré-aliança pode reforçar ou dificultar a formação de uma determinada aliança, respectivamente, especialmente quando os interesses convergirem (ou divergirem) em diferentes temas. ${ }^{459} \mathrm{Na}$ mesma linha, localização geográfica ou topografia podem modificar o padrão de conflito entre dois países: quão mais próximo, mais material para conflito; quão mais próximo, mais ameaçador um país pode se parecer em relação ao outro. ${ }^{460}$ Nesse ponto, Snyder realça a intensidade dos conflitos como propulsor de um eventual alinhamento. ${ }^{461}$

\footnotetext{
$458 \quad$ Ibid., p. 60. Adiante, Snyder acrescenta que: "[T]he strength of incentives to ally and the determinacy of partners will depend on the intensity of conflicts and the degree of strength inequalities, and whether these variables are mutually reinforcing or opposed. When conflicts are severe and particularly when the same states are in conflict on several issues, the drive to ally formally will be strong and the likely partners will be quite clear. When conflicts are mild and nonreinforcing and strength differences are small, there may be little more pressure to ally than in our initial model of pure anarchy, or the probable identity of allies will be quite ambiguous." (Ibid., p. 62).

${ }_{459} \quad$ "Obviously, states will have more reason to ally when they have specific conflicts with other states, thus more reason to fear attack, than when their only sense of threat comes from systemic anarchy." (Ibid., p. ${ }_{460}^{61)}$.

$460 \quad$ Ibid., p. 61.

$461 \quad$ Ibid., p. 62.
} 
De fato, a pré-existência de conflitos altera os valores dos efeitos da aliança sobre os aspectos de dissuasão, defesa e preclusão em relação a uma terceira parte (em geral o oponente). As situações são variadas: a pré-existência de conflitos entre uma situação envolvendo três unidades pode, por exemplo, reforçar ou diminuir a expectativa de ser assistido por uma das unidades (causando um problema de confiabilidade dentro da aliança).

A Tabela 2 abaixo reproduz as configurações apresentadas nas Figuras 1 a 4 acima, diante da adição de informação sobre eventual conflito entre duas das três partes, sendo evidente o impacto de tais conflitos sobre o resultado final das alianças de maior valor:

Tabela 2 - Ganhos Obtidos com Alianças

\begin{tabular}{|c|c|c|c|}
\hline Sem conflito & Conflito entre A e B & $\begin{array}{c}\text { Conflito entre A e B; A e } \\
\text { C }\end{array}$ & Conflito entre B e C \\
\hline \multicolumn{4}{|c|}{ Configuração I: capacidades iguais $A=B=C$} \\
\hline $\mathrm{AB}=120(60,60)$ & $\mathrm{AB}=80(40,40)$ & $\mathrm{AB}=80(60,20)$ & $\mathrm{AB}=120(40,80)$ \\
\hline $\mathrm{AC}=120(60,60)$ & $\mathrm{AC}=120(80,40)$ & $\mathrm{AC}=80(60,20)$ & $\mathrm{AC}=120(40,80)$ \\
\hline $\mathrm{BC}=120(60,60)$ & $\mathrm{BC}=120(80,40)$ & $\mathrm{BC}=120(60,60)$ & $\mathrm{BC}=80(40,40)$ \\
\hline \multicolumn{4}{|c|}{ Configuração II: dois fracos; um forte $A>B=C$; $A<B+C$} \\
\hline $\mathrm{AB}=60(0,60)$ & $\mathrm{AB}=20(-20,40)$ & $\mathrm{AB}=20(0,20)$ & $\mathrm{AB}=60(-20,80)$ \\
\hline $\mathrm{AC}=60(0,60)$ & $\mathrm{AC}=60(20,40)$ & $\mathrm{AC}=20(0,20)$ & $\mathrm{AC}=60(-20,80)$ \\
\hline $\mathrm{BC}=160(80,80)$ & $\mathrm{BC}=160(100,60)$ & $\mathrm{BC}=160(80,80)$ & $\mathrm{BC}=120(60,60)$ \\
\hline \multicolumn{4}{|c|}{ Configuração III: dois fortes; um fraco $A<B=C$} \\
\hline $\mathrm{AB}=60(20,40)$ & $\mathrm{AB}=20(0,20)$ & $\mathrm{AB}=20(20,0)$ & $\mathrm{AB}=60(0,60)$ \\
\hline $\mathrm{AC}=60(20,40)$ & $\mathrm{AC}=60(40,20)$ & $\mathrm{AC}=20(20,0)$ & $\mathrm{AC}=60(0,60)$ \\
\hline $\mathrm{BC}=0(0,0)$ & $\mathrm{BC}=0(20,-20)$ & $\mathrm{BC}=0(0,0)$ & $\mathrm{BC}=-40(-20,-20)$ \\
\hline \multicolumn{4}{|c|}{ Configuração IV: capacidades desiguais $\mathrm{A}>\mathrm{B}>\mathrm{C}$; $\mathrm{A}<\mathrm{B}+\mathrm{C}$} \\
\hline $\mathrm{AB}=-20(0,-20)$ & $\mathrm{AB}=-60(-20,-40)$ & $\mathrm{AB}=-60(0,-60)$ & $\mathrm{AB}=-20(-20,0)$ \\
\hline $\mathrm{AC}=60(20,40)$ & $\mathrm{AC}=60(40,20)$ & $\mathrm{AC}=20(20,0)$ & $\mathrm{AC}=60(0,60)$ \\
\hline $\mathrm{BC}=160(80,80)$ & $\mathrm{BC}=160(100,60)$ & $\mathrm{BC}=160(80,80)$ & $\mathrm{BC}=120(60,60)$ \\
\hline
\end{tabular}

Fonte: Snyder (1997), p. 63

Com a determinação dos valores de cada aliança, pondera Snyder que o exercício acerca da formação de alianças não estará completo até que se adicione a fase da barganha, ou seja, verificar como os países negociarão os termos da aliança. Isso somente será possível por meio de uma análise a partir da teoria dos jogos. Ou seja, Snyder indica ser necessário analisar as alternativas disponíveis aos diferentes países (estática) à luz da dinâmica das relações, na medida em que negociações de alianças podem levar a 
compromissos assimétricos (ao passo que uma análise estática considera apenas compromissos simétricos), além de compromissos de outras naturezas, ou mesmo pagamento a latere (side payments).

Seria já demasiado reproduzir neste texto o encadeamento da análise empreendida por Snyder, para avaliar o processo de barganha da formação de alianças, a partir do qual deriva algumas importantes conclusões. Inicialmente, interessa pontuar que a decisão sobre a formação de alianças depende de uma análise das alternativas disponíveis para um determinado país. E tal decisão dependerá se a aliança formada é possível (ou seja, resulta em situação melhor do que o status quo) e competitiva (por proporcionar mais valor para todos seus membros do que outras alianças), tendo em mente outras possibilidades de alinhamento relevantes (aliança não-competitiva que influencia a barganha entre e através das possibilidades competitivas).

Em uma situação envolvendo três unidades, a distribuição dos payoffs entre as unidades determinaria as possibilidades de formação. Considere-se a seguinte situação:

$$
\text { Caso 1: } \quad \begin{aligned}
& \mathrm{AB}=120(60,60) \\
& \mathrm{AC}=120(60,60) \\
& \mathrm{BC}=120(60,60)
\end{aligned}
$$

$$
\begin{aligned}
& \text { Caso 1A: } \quad \mathrm{AB}=120(70,50) \\
& \mathrm{AC}=100(70,30) \\
& \mathrm{BC}=80(50,30)
\end{aligned}
$$

No Caso 1, qualquer uma das alianças é possivel, pois todas melhoram a situação de cada uma das unidades, comparadas ao status quo. Todas as unidades obterão um ganho de 60 , seja qual for a alternativa escolhida, não havendo espaço para qualquer unidade forçar a escolha de uma aliança sobre outra, pela ausência de poder de barganha em seu favor. Em uma situação como essa, não é possível prever qual aliança se formará. Alterando-se os payoffs do Caso 1 (chegando-se à distribuição refletida no Caso 1A), verifica que mesmo que haja diferença nos valores intrínsecos de cada uma das três possibilidades de aliança, não é possível prever qual aliança será formada, pois cada uma das unidades detém uma alternativa de igual valor comparada com sua outra alternativa (A 
leva 70 ao se alinhar com B ou C; B ganha 50 ao se alinhar com A ou C; e C aufere 30 se se alinhar com A ou C). Deduz-se, portanto, que a aliança de maior valor não é necessariamente a aliança que será formada.

Caso 2: $\quad \mathrm{AB}=120(80,40--40,80)$

$$
\begin{aligned}
& \mathrm{AC}=40(40,0) \\
& \mathrm{BC}=40(40,0)
\end{aligned}
$$

Já no Caso 2, verifica-se que as três alianças são possíveis, por proporcionarem uma situação melhor do que o status quo. A aliança mais competitiva, todavia, é AB. Para $\mathrm{A}$, a outra alternativa seria $\mathrm{AC}$, que se apresenta relevante para A. Dentre o payoff possível para $\mathrm{A}$ em $\mathrm{AB}$, há uma indefinição entre a distribuição de payoffs (se A leva 40 ou 80, ou vice-versa), que dependerá das negociações entre ambos. ${ }^{462}$ De qualquer forma, o fato de haver a possibilidade de obter 80 (ou algo entre 40 e 80 ), torna a alternativa $A B$ mais competitiva do que AC para A. Com a mesma situação se depara B, confluindo-se para a formação da aliança $\mathrm{AB}$, embora dependente de uma negociação entre as partes.

Caso 3: $\quad \mathrm{AB}=120(120,0-0,120)$

$$
\begin{aligned}
& \mathrm{AC}=-10(-10,0) \\
& \mathrm{BC}=-10(-10,0)
\end{aligned}
$$

O Caso 3 é fácil de resolver, pois as alianças $\mathrm{AC}$ e $\mathrm{BC}$ não são competitivas para $\mathrm{A}$ nem para B, eliminando-se a hipótese de alinhamento com $\mathrm{C}$, provavelmente porque exista algum tipo de conflito com tal país, que impeça a formação de aliança (é pior do que o

\footnotetext{
$462 \quad$ "Assume the alliance under negotiation promises better payoffs for both parties than they could get elsewhere - that there is a 'surplus' to be divided by negotiation. Both can gain within a range, the endpoints of which are the values each party could obtain in its best alliance alternative, including the alternative of no alliance. Strictly speaking, it is indeterminate where, within the range, the settlement will fail. John F. Nash, however, showed that it will fall at the point at which the product of the utilities of the bargainers is maximized, given certain plausible assumptions. Thus in Figure 2-6 the bargaining range runs between $P$ and $R$, the values of each party's alternatives, and $Q$ is the Nash solution. The line PQR is also the Pareto-optimal line that marks the maximum benefit the parties can achieve jointly. Once the parties are on this line, any improvement of the terms of one bargainer can only be at the other's expense. If they are below this line, say at point $M$, they can still gain jointly. Moving upward from $M$, the parties might bargain about the type of alliance to form - nonaggression pact, pact of neutrality, entente, mutual defense alliance, and so on - until they arrive at the type that is mutually most advantageous on the Pareto-optimal line. Then they would move back and forth on that line, each party offering terms favorable to itself, until theoretically they settle at $Q$, the Nash solution." (Ibid., pp. 76-77).
} 
status quo). Pode-se então prever que a aliança $\mathrm{AB}$ se formará, embora também dependa da definição da distribuição dos payoffs, a partir da negociação entre as partes da aliança.

Após realizar o mesmo tipo de exercício com situações envolvendo duas unidades e outra com mais de três unidades, Glenn H. Snyder chega às seguintes hipóteses acerca da formação de aliança, passada a fase da barganha: ${ }^{463}$

1. A distribuição de payoffs em uma aliança refletirá o valor inerente da aliança para cada um de seus membros e o valor de suas alternativas disponíveis;

2. Ao estimar o valor das alternativas disponíveis a si e aos potenciais aliados, deve-se considerar o valor de todas as alternativas no sistema, para todos os seus membros;

3. Tomando-se todas as alternativas disponíveis, resultará um espectro (range) de barganha estabelecido pelo valor das alternativas de cada parte, dentro do qual estarão os termos do contrato, ou um determinado ponto representando os termos em que os payoffs de cada (ou todas) as partes nesta aliança são exatamente iguais ao que se poderia obter em outras alternativas;

4. Haverá um espectro (range) de barganha quando ambas (todas) as partes valorarem a aliança sob negociação mais do que sua melhor alternativa; tal aliança se formará, mas seus termos são indeterminados;

5. Payoffs convergirão para um ponto quando todas as alianças possíveis forem valorosas comparativamente por seus membros; neste caso, qualquer uma das alianças poderá se formar e os payoffs de seus membros serão determinados;

6. A aliança mais valiosa não necessariamente é a que se forma;

7. Algumas alianças, que logicamente não formariam, influenciarão a distribuição de payoffs naquelas que se formarem (alianças relevantes).

A partir desse arcabouço teórico, Snyder realizou análise das alianças que marcaram o final do Século XIX na Europa. Snyder justificou a escolha de tais alianças por estarem em um sistema de estrutura multipolar e porque seu objetivo teórico era identificar e ilustrar a lógica da formação de alianças em tal sistema, não adentrando sistemas uni- ou bipolares. Nesse sentido, acrescenta Snyder ainda que, nesse contexto, a formação de alianças é produto de um sistema anárquico e multipolar, da desigualdade de

$463 \quad$ Ibid., p. 75. 
capacidades e da existência de interesses comuns ou conflitos entre estados, considerandose um determinado processo de barganha.

Posto isso, quer nos parecer que a teoria apresentada por Snyder (dentro do contexto do arcabouço teórico sobre formação de alianças até então desenvolvido) se apresenta de utilidade substancial para se analisar a formação de alianças no âmbito do $\mathrm{SSC} / \mathrm{OMC}$, conforme desenvolvido no próximo Capítulo. 


\section{FORMAÇÃO DE ALIANÇAS NO SSC/OMC}

\section{A. Introdução}

A partir do arcabouço teórico exposto acima, esta tese pretende analisar as condições de formação de alianças no contexto do SSC/OMC, visando à aplicação de retaliação coletiva. Caso as características do SSC/OMC sejam favoráveis à formação de coalizões, os Membros poderão então considerar como válida a proposta de implementação de uma sistema de retaliação coletiva no âmbito do SSC/OMC. Esse é o objetivo central desta tese: perquirir se os fatores básicos ao alinhamento estão presentes e, em caso positivo, sob quais condições tais alinhamentos deverão ocorrer. Dada uma resposta positiva às questões acima postas, a identificação de tais condições será crucial para que se possa elaborar uma proposta que, levando em consideração as condições presentes, permita/fomente a formação de alianças, com vistas a tornar mais eficaz o $\mathrm{SSC} / \mathrm{OMC}$, ou seja, a induzir os Membros a cumprirem com suas obrigações no âmbito do Acordo da OMC.

Primeiramente, deve-se esclarecer que, para se realizar tal análise, opta-se expressamente pela abordagem realista, tal qual definida no Capítulo $\mathrm{V}$ acima.

Dessa feita, haja vista que a obra de Snyder se mostra como a tentativa mais completa de sistematização da teoria da formação de alianças, opta-se pela adoção da parte introdutória do estudo empreendido por Glenn H. Snyder, mediante a identificação e análise dos elementos Estrutura, Unidades, Relacionamentos e Interação, para se identificar os fatores básicos ao alinhamento do SSC/OMC. Contribuições trazidas por outros autores poderão ser mencionadas, na medida em que tenham sido incorporadas ou corroboradas por Snyder (far-se-ão as devidas anotações nesse sentido).

Uma vez identificados os fatores propícios ao alinhamento, procurar-se-á analisar situações de limite específicas, em que o sistema poderia ter se valido de contramedidas coletivas, ou seja, as onze arbitragens nas quais houve autorização para aplicação de contramedidas, descritas no Capítulo II acima. As situações fáticas de tais arbitragens 
servirão de ilustração para se perquirir sobre a utilidade de um eventual mecanismo de retaliação coletiva, cujos contornos jurídicos, caso a resposta seja positiva, serão abordados no Capítulo seguinte. A aplicação desses conceitos ao SSC/OMC deverá ajudar a concluir pela possibilidade de implementação, total ou parcial (com indicação de suas limitações e eventuais fragilidades), de um mecanismo de retaliação coletiva no âmbito do SSC/OMC.

\section{B. Identificação dos Fatores para Formação de Alianças no Âmbito do SSC/OMC}

Antes de adentrar a análise dos fatores que favorecem ou não a formação de alianças no $\mathrm{SSC} / \mathrm{OMC}$, há que se perquirir se um eventual descumprimento de uma decisão do OSC por parte um determinado Membro poderia ser percebido como uma ameaça tal a levar os demais Membros a se aliarem para induzir o Membro demandado a adotar a recomendação do OSC. Com efeito, conforme exposto anteriormente, a formação de alianças é impulsionada não somente por uma situação de equilíbrio de poder, mas também por uma situação de desequilíbrio de ameaças (balance-of-threat), ou seja, quando um país se mostre especialmente perigoso ("balance-of-threat theory predicts that states seek allies when there is an imbalance of threat (that is, when one state or coalition is specially dangerous)"). ${ }^{464}$

Quer nos parecer que, a essa altura do debate, a desobediência contumaz por parte de um Membro da OMC no tocante a decisões do OSC é algo que preocupa sobremaneira os demais Membros, revelando-se como verdadeira ameaça ao SSC/OMC, pela descrença que gera nos Membros mais fracos e pela sensação de ilegitimidade que empresta a todo o sistema multilateral de comércio, em que uns podem mais do que outros.

Ao nosso ver, são expressão desse entendimento: a própria evolução do SSC/OMC, tal qual registrado nas disposições do $E S C,{ }^{465}$, bem como o regime de enforcement

\footnotetext{
$464 \quad$ Vide nota de rodapé 412 e texto que a acompanha.

465 Vide nota de rodapé 471 abaixo e texto que a acompanha (evolução do sistema para monopólio interpretativo e de enforcement). Como indica Amaral Jr., apoiado em do Prado: "Victor do Prado salienta três características do mecanismo de solução de controvérsias formado na Rodada Uruguai: a abrangência, a automaticidade e a exequibilidade. A abrangência se reporta à competencia do mecanismo de solução de controvérsias para apreciar a violação de todos os acordos da $\mathrm{OMC}$ e ao fato de que inexiste outro órgão com atribuição de solucionar tais litígios. A automaticidade consiste nos estágios sucessivos que as demandas percorrem, conforme limites temporais rígidos, necessários para tolher a ação unilateral dos membros com
} 
característico do $\mathrm{SSC} / \mathrm{OMC} ;^{466}$ as manifestações apresentadas pelos diferentes Membros nas reuniões do Grupo Negociador; ${ }^{467}$ os posicionamentos doutrinários favoráveis que em sua maioria atualmente advogam a necessidade de cumprimento in natura das obrigações perante o OSC; ${ }^{468}$ o conjunto das decisões proferidas nas arbitragens do Artigo 22.6 do $E S C$, que em sua grande maioria identificaram o objetivo das contramedidas como sendo de indução ao cumprimento. ${ }^{469}$

\section{Estrutura}

O primeiro elemento a se identificar é a Estrutura do SSC/OMC, a ser definida pela identificação (i) como um sistema (a) anárquico ou hierárquico; e (b) uni, bi ou multipolar; e (ii) das unidades que o compõem.

\section{a) Anarquia ou Hierarquia}

Como exposto anteriormente, tem-se que um sistema possa ser estruturado dentro de uma anarquia ou uma hierarquia, sendo a primeira caracterizada pela ausência de um ente governamental que garanta a execução de contratos ou promova segurança coletiva, em contraste com os sistemas hierárquicos domésticos. ${ }^{470}$

Dada essa definição, resta nítido que o sistema de solução de controvérsias da $\mathrm{OMC}$ se encontra dentro de uma estrutura anárquica. Embora a $\mathrm{OMC}$, como resultado da Rodada Uruguai, tenha passado por uma transformação profunda em termos de institucionalização e de adensamento de juridicidade, como apontado antes, ${ }^{471}$ tal evolução não levou a OMC a uma posição de ente governamental, ou, no limite, supranacional.

vistas a retardar indevidamente o processo. A exequibilidade, por seu turno, evidencia que a OMC pode obrigar os membros a cumprir as decisões do Órgão de Solução de Controvérsias, mediante a imposição de sanções aos violadores. Adicionam-se a estas características a dupla instância e a supervisão multilateral por todos os membros para a aprovação dos relatórios dos painéis e do Órgão de Apelação. Esses traços dão à OMC posição singular no quadro das organizações internacionais da atualidade." (Amaral Jr. (2008), p. 103). $466 \quad$ Vide nota de rodapé 3 e texto que a acompanha.

$467 \quad$ Vide nota de rodapé 5 e texto que a acompanha.

$468 \quad$ Vide Capítulo II.C acima.

$469 \quad$ Vide Capítulo II.D acima.

$470 \quad$ Vide nota de rodapé 428 e texto que a acompanha.

471 Vide nota de rodapé 465 e texto que a acompanha. Alberto do Amaral Jr. enfatiza exatamente esses pontos: "A nova disciplina devotou-se à tarefa de corrigir os vícios que impregnavam o sistema anterior: a excessiva fragmentação, a morosidade procedimental e o não-cumprimento das recomendações e decisões 
A OMC é uma instituição internacional que favorece o surgimento de cooperação de seus Membros dentro do regime de comércio internacional, mediante o emprego de técnicas de transparência, construção de capacidades (capacity building), facilitação das negociações (seja por meio de seu Secretariado, seja como mero ponto focal das negociações), e enforcement.

No tocante ao enforcement, já é bastante conhecido que a Rodada Uruguai trouxe notáveis avanços ao SSC/OMC, tornando-o o mecanismo de solução de controvérsias mais evoluído no direito internacional público, ao ter eliminado os entraves deliberatórios para aprovação de relatórios de painéis (e do Órgão de Apelação), mediante a inversão da regra do consenso positivo (para a regra do consenso negativo), compilação das regras procedimentais a serem seguidas nos contenciosos levados ao OSC, mas, sobretudo, por meio da instituição de uma exclusividade do SSC/OMC na interpretação das normas da OMC e na aplicação de sanções por suposta violação aos compromissos ou obrigações relativas ao sistema multilateral de comércio (Artigo 23, ESC). ${ }^{472}$

A despeito de tais características, que parecem indicar que a OMC caminha rumo à hierarquização, definitivamente, ainda não é possível concluir que a $\mathrm{OMC}$ tenha sido guindada à condição de um ente governamental, continuando o sistema internacional de comércio a se estruturar como uma anarquia.

dos painéis. A referência feita no artigo XVI, $\S 1^{\circ}$, de que salvo diposição em contrário a OMC "shall be guided by the decisions, procedures and costumary practices followed by the Contracting Parties to GATT 1947 and the bodies established in the framework of GATT 1947'"[nota de rodapé omitida] mostra que a continuidade vincula a solução de controvérsias no GATT e na OMC. Esse sentido de continuidade vincula a solução de controvérsias no GATT e na OMC. Esse sentido de continuidade exprime-se nas alusões que os painéis e o Órgão de Apelação fazem à jurisprudência do GATT quando resolvem conflitos acerca da interpretação dos tratados da OMC. Consuma-se, assim, a transição de um sistema predominantemente diplomático, baseado na negociação entre as partes, que marcou a experiência do GATT, para um sistema organizado em torno de regras jurídicas." (Amaral Jr. (2008), p. 101).

472 Tal monopólio restringiu o uso de determinadas normativas dos EUA e da Comissão Europeia, as quais eram utilizadas para examinar a compatibilidade de determinadas medidas de outros países com as regras do comércio internacional, no caso, a Section 301 e a Trade Barriers Regulation, respectivamente. Tais regulamentações foram objeto posteriormente de contenciosos questionando a compatibilidade de determinadas medidas tomadas com base em tais legislações, a saber, os contenciosos United States of America - Sections 301-310 of the Trade Act 1974 [DS152], iniciada em 25 de novembro de 1998, e European Communities - Measures Affecting Trade in Commercial Vessels [DS301], iniciada em 3 de setembro de 2003. 
Com efeito, em uma anarquia, as unidades procuram assegurar o cumprimento de suas obrigações por meio de mecanismos próprios (ou seja, o chamado self-help). ${ }^{473}$ No âmbito da OMC, eventuais violações das obrigações ou compromissos assumidos pelos diferentes Membros somente são resolvidas (solucionadas) por iniciativa do Membro cujos direitos tenham sido anulados (com efeito, a iniciativa cabe ao Membro, não havendo previsão no ESC de atuação de ofício do OSC). Da mesma forma, após declaração da incompatibilidade da medida em questão, o Membro deverá se valer de suas próprias capacidades para induzir o Membro demandado a adotar a recomendação do OSC, já que a estrutura bilateral das contramedidas, prevista no Artigo XXIII do GATT 1947, não foi modificada no GATT 1994.

Ou seja, embora o SSC/OMC tenha sofrido uma transformação rumo à institucionalização (no sentido de que todo o percurso processual que culmina na aplicação de contramedidas seguem as normas da instituição), a parte final do sistema de enforcement (cumprimento das obrigações) continua baseada em medidas de self-help, já que depende da capacidade indutora bilateral do Membro demandante, não diferindo em nada de um sistema anárquico. Tal capacidade se perfaz nos compromissos ou obrigações que o Membro demandante possa, bilateralmente, suspender em relação ao Membro demandado. Nada mais. Com isso, o sistema de enforcement da OMC ainda se baseia no princípio da força, do poder e, enquanto não se transformar em um sistema hierárquico, por conseguinte, deverá ser aplacado pela força, pelo poder, nos dizeres de Morgenthau (“somente o poder limita o poder"). ${ }^{474}$ Como também indicado anteriormente, daí deriva, na melhor tradição sobre equilíbrio de poder, a necessidade de os Membros se aliarem (Keohane (1984)), ${ }^{475}$ no caso, para preservarem seus direitos no âmbito do SSC/OMC.

\footnotetext{
473 "But world politics is decentralized rather than hierarchic: the prevailing principle of sovereignty means that states are subject to no superior government (Ruggie, 1983a). The resulting system is sometimes referred to as one of 'self-help'. (Waltz, 1979). (...) Sovereingty and self-help mean that the principles and rules of international regimes will necessarily be weaker than in domestic society. In a civil society, these rules 'specify terms of exchange' within the framework of constitucional principles (North 1981, p. 203). In world politics, the principles, norms, and rules of regimes are necessarily fragile because they risk coming into conflict with the principle of sovereignty and the associated norm of self-help. They may promote cooperation, but the fundamental basis of order on which they would rest in a well-ordered society does not exist. They drift around without being tied to the solid anchor of the state." Keohane (1984), p. 62.

$474 \quad$ Vide nota de rodapé 353 e texto que a acompanha.

$475 \quad$ "Yet even if the principles of sovereignty and self-help limit the degree of confidence to be placed in international agreements, they do not render cooperation impossible. Orthodox theory itself relies on mutual interests to explain forms of cooperation that are used by states as instruments of competition. According to balance-of-power theory, cooperative endeavors such as political-military alliances necessarily form in selfhelp systems (Waltz, 1979)." Keohane (1984), p. 62.
} 
Ademais, a celebração de acordos de livre comércio bilateral entre os próprios Membros da OMC dá mostras adicionais de que a atuação da OMC não é monopolística, sofrendo a concorrência de outros subsistemas, de caráter regional ou local, retirando-lhe uma das características essenciais dos sistemas hierárquicos.

\section{b) Polaridade: uni- ou multipolaridade?}

É crucial a determinação de se o sistema multilateral de comércio se compõe em uma unipolaridade, uma bipolaridade ou uma multipolaridade.

Retomando os conceitos anteriormente expostos, tem-se que haverá unipolaridade quando uma determinada unidade reúna mais capacidades do que as demais unidades conjuntamente; bipolaridade, quando a maioria das capacidades estiver concentrada nas mãos de duas unidades (“dois grandes poderes"); e multipolaridade, quando forem mais do que duas as grandes potências em um determinado sistema (Stephen M. Walt). ${ }^{476}$

Em um contexto de segurança, a análise da polaridade se dá por meio de um exame ou cômputo das capacidades detidas pelas unidades do sistema. Por exemplo, no pósguerra, em 1945, era evidente que emergia um mundo bi-polar, pela existência de duas unidades (EUA e União Soviética) detendo a maioria das capacidades mundiais, em comparação com as demais unidades existentes. O advento dos armamentos nucleares realçou ainda mais tal dualidade e bipolaridade.

Em um contexto de comércio internacional, literatura e comentários têm proliferado acerca da evolução havida no sistema multilateral de comércio entre uma uniou bipolaridade (de EUA e o bloco europeu), ${ }^{477}$ em 1947, quando da realização das Conferências de Bretton Woods, ${ }^{478}$ para atingir uma pluripolaridade entre as décadas de

\footnotetext{
$476 \quad$ Vide nota de rodapé 429 e texto que a acompanha.

$477 \quad$ Evenett (2007), pp. 2-4.

$478 \quad$ "Once upon a time, the world was dominated by a hegemon, or so goes the familiar story. It is easy enough to see the General Agreement on Tariffs and Trade (GATT) of 1948 as a public good supplied by the United States alone, but by the 1960s the GATT could be seen as a bilateral agreement with Europe. That model was still a good approximation in the Tokyo Round of the 1970s, but it was clear from the roles played by Brazil and India in shaping the launch of the Uruguay Round in the 1980s that things had begun to change. Either power was shifting into new hands, or new forms of power had emerged. The Blair House
} 
1980-90 (com o famoso Quad, formado por EUA, Comunidade Europeia, Japão e Canadá), até a multipolaridade dos dias atuais. ${ }^{479}$ Em termos de multipolaridade, enfoque tem sido dado à participação ativa de Brasil, China e Índia no sistema multilateral de comércio, já identificados como potenciais candidatos a pólos nesse sistema, seja pelo papel desempenhado junto às negociações da OMC, seja pelas suas capacidades econômico-comerciais, conforme defende Evenett. ${ }^{480}$

Nesse sentido, quer nos parecer que o cômputo das capacidades deva se dar diferentemente de uma análise das capacidades verificadas em um contexto de segurança militar.

Com efeito, em se tratando de uma área-tema (issue-area) autônoma, a análise das capacidades deve considerar elementos relevantes a tal área-tema. Keohane sustenta esse

accord between the United States and the European Union was necessary to conclude the Uruguay Round, but far from sufficient. It would still be foolhardy to pretend that any round would end before the United States and the EU are ready, yet they cannot force an outcome. It follows that the notion that the Doha suspension suggests the need for institutional reform rests on two interrelated assumptions about the changing nature of global politics. First, institutional reform is said to be needed to accommodate the rise of new powers (especially Brazil, India, and China)." (Wolffe (2007), p. 4).

$479 \quad$ "Critical mass implies that markets that represent a significant share of global production and consumption should help to supply the systemic public good. Yet, if current material power determined the relative hierarchy of WTO Members, it would be hard to understand the list of countries that appear to play leading roles. The original Quad (the United States, the EU, Japan, and Canada) still includes the largest markets, but they can no longer supply systemic leadership alone. China, India, and Brazil are often mentioned as the most important new powers - although only China has entered the ranks of the top traders (see Wolfe 2006). These three are not powers on the scale of the United States, but they now have the collective strength to challenge the established order (Hurrell 2006)." (Ibid., p. 5).

${ }_{480} \quad$ "Which nations are likely to join the EU and the USA as leading trade powers? This question is difficult to answer with certainty, however, recent economic performance and the profile adopted during the Doha Round of negotiations suggest, initially, three potential candidates namely, Brazil, China, and India. As the data reported in Table 1 indicates, in purchasing power parity terms, after 30 years of fast growth China now has an enormous economy, whose gross domestic product (GDP) is two-thirds that of the size of the U.S. economy.[nota de rodapé omitida] Underlying China's phenomenal economic growth has been an export boom that has seen it become the third largest exporter of merchandise goods in the world (see Table 1). The ratio of total imports plus exports to GDP in China is just under 65 percent, a level far higher than in the U.S., EU [nota de rodapé omitida], Brazil, and India. China's growing clout has been recognised by its trading partners and, indeed, some have contended that fear of competitive Chinese exports has made some WTO members more reluctant to liberalise under the auspices of the Doha Round. Even if China's growth rate were to halve over the decade to come then it would still be a sizeable economic power. Together, these matters justify further consideration of China as a potential pole of the world trading system." (Ibid.)

In contrast the case in favour of Brazil and India's emergence as poles is less clear cut. Brazil and India are the 15th and 20th largest exporters of merchandise goods in the world, respectively (see Table 1). Moreover, neither country's trade-to-GDP ratio is exceptionally high. Even so, both countries are regional powers and have been keen to raise their profile globally. Both countries have played a central role in the Doha Round negotiations and have built worldwide coalitions of WTO members, which is one important characteristic of leading trading powers. Their inclusion as potential poles is more of a reflection of this fact than because of their prior economic performance. Having said that, both countries (and India in particular) may in the future become global economic powerhouses." (Evenett (2007), p. 8). 
posicionamento ao indicar, com base em Waltz, que um determinado sistema internacional poderá ter diferentes estruturas, diferindo-se em áreas-temas e de acordo com os recursos que possam ser usados para afetar seus objetivos: "different sets of capabilities will qualify as 'power resources' under different conditions". Keohane e Nye denominam tal diferenciação como teorias de "área-estrutura" (structure-area), em que a força militar, embora importante, não se assume esteja mais sob o topo da hierarquia dos recursos de força. ${ }^{481}$ Identificando que as capacidades de poder devem se ajustar aos objetivos visados, Keohane defende que "power resources are differently effective across issue-areas, and the usability of a given set of power resources depends on the 'policy-contingency frameworks', within which it must be employed."

Keohane e Nye (1977) já sustentavam que a análise da estrutura de uma determinada "área-tema" deve se ajustar, na medida em que as capacidades utilizadas em uma determinada "área-tema" não são necessariamente eficazes em outra "área-tema". Da mesma forma, "dominant rule-making power in one area does not necessarily imply effective control over other areas as well". Construindo sobre a diferenciação entre questões de segurança (classificada como "alta política", por estarem no topo da hierarquia das relações internacionais) ${ }^{482}$ e outras questões (dentre as quais o comércio internacional, expressamente mencionado no texto), Keohane e Nye (1977) asseveram que "[W] here the use or threat of force is ineffective, it will be more difficult for a major power, in what would formerly have been a hegemonial position across the board, to influence policy in one issue area by using resources not specific to that area". 483

Isso leva a inferências importantes, pois a hegemonia - ou unipolaridade existente na área de segurança (detida pelos EUA), não é automaticamente transferida para à "área-tema" de comércio internacional. Isso implica que as capacidades existentes na "área-tema" de segurança não sejam necessariamente utilizadas na "área-tema" de comércio internacional, nem mesmo causem impacto no tocante à estrutura dessa "áreatema" e, por conseguinte, sobre o comportamento das unidades/países. Keohane e Nye (1977) ainda sustentam que "[t]he premise of issue structuralism is that power resources in

$481 \quad$ Keohane (1986), p. 184, citando Keohane e Nye (1977), caps. 3 e 6.

$482 \quad$ "(...) However, one must assume that there is a hierarchy of issues, with military security at the top, and that force is usable, since otherwise one could find very different patterns of politics and regimes, for different issue areas." Keohane e Nye (1977) p. 49.

$483 \quad$ Keohane e Nye (1977), p. 49. 
one area lose some or all of their effectiveness when applied to others" ${ }^{484}$ Ressaltam ainda que quanto mais complexa for a interdependência, maior será a relevância da análise por "áreas-temas" (ênfase no estruturalismo de tema - "issue structuralism"). ${ }^{485}$

Mais recentemente, o professor de relações internacionais de Harvard, Joseph S. Nye Jr., retomou o tema da caracterização do mundo atual como uni- ou multipolar. Para Nye, equivoca-se quem analisa o mundo considerando tão-somente uma única dimensão, em geral, da pujança militar detida pelos EUA. ${ }^{486} \mathrm{O}$ problema decorrente de tais caracterizações seria, de um lado, superestimar a capacidade dos EUA de atingir objetivos em certas dimensões da política mundial, e, do outro lado, superestimar a importância de determinados países, dentro da multipolaridade.

Nesse sentido, complementando as discussões sobre a existência de diferentes “áreas-temas", Nye apresenta a metáfora do "jogo de xadrez tridimensional”, em que se distribuiria o poder entre as nações. No tabuleiro superior do xadrez tridimensional, referente ao poderio militar, haveria uma preponderância unipolar, pela já sabida superioridade norte-americana em tais termos. O tabuleiro do meio comporta o poder econômico, que Nye considera como sendo multipolar, pela participação da Europa, Japão e China (a alcunha BRICs não havia sido ainda inventada). Nesse ponto, Nye elabora ao afirmar que "nesse tabuleiro econômico, os Estados Unidos não são hegemônicos e muitas vezes precisam negociar em termos de igualdade com a Europa. Isto levou alguns a falarem num mundo híbrido, uni-multipolar". ${ }^{487} \mathrm{O}$ tabuleiro de baixo se refere às relações transnacionais "que transpõem as fronteiras e escapa ao controle governamental" e em que o poder estaria amplamente disperso, descabendo discussão centradas em polaridade. ${ }^{488}$

$484 \quad$ Keohane e Nye (1977), p. 50. Ainda: "Power will not be fungible, as in the overall structure model; military capabilities will not be effective in economic issues, and economic capabilities relevant to one area may not be relevant to another. (...) It is clear that different issue areas often have different political structures, that may be more or less insulated from the overall distribution of economic and military capabilities. They differ greatly in their domestic politics, in their characteristic patterns of politicization, and in the interest groups that are active." Ibid.

$485 \quad$ Keohane e Nye (1977), p. 60.

486 "Com a derrocada da União Soviética, alguns passaram a descrever o mundo resultante como unipolar, outros, como multipolar. Ambos os grupos têm razão e ambos se equivocam, visto que cada qual se refere a uma dimensão diferente do poder que já não se pode supor homogeneizada por força da supremacia militar." Nye (2002), p. 79.

$487 \quad$ Nye (2002), p. 79.

488 "Esse reino inclui agentes não estatais completamente diversos: num extremo, banqueiros transferindo eletronicamente importâncias mais vultosas que a maioria dos orçamentos nacionais, no outro, terroristas empreendendo ataques e hackers prejudicando as operações da internet. Nesse tabuleiro inferior, o 
Conclui Nye que "quem participa de um jogo tridimensional perde se se concentrar unicamente no tabuleiro interestatal militar, deixando de lado os outros e as conexões verticais entre eles." No mesmo sentido se posiciona Daniel Drezner, ao enfatizar que, embora a ideia de hegemonia norte-americana funcione bem no terreno da segurança, "it is far from clear whether such an assumption is accurate when thinking about the global political economy". ${ }^{489}$ Drezner desafia o poderio militar como suficiente para atingir objetivos em áreas como a política econômica global, questionando sua decantada fungibilidade.

Dentro desse contexto, resta evidente que as questões objeto deste trabalho se posicionam no tabuleiro do meio, em que cada vez mais se estrutura uma nítida multipolaridade.

Nesse diapasão, para os fins deste Capítulo, não nos parece necessário se deter sobre as capacidades que devem compor o poderio nacional de cada um dos Membros da OMC. Tal discussão, neste Capítulo, seria desnecessária, pois parece não haver mais dúvida acerca da característica de multipolaridade no sistema de comércio multilateral.

A título ilustrativo apenas, tomando-se informações divulgadas pela OMC, pode-se inferir que o comércio internacional apresenta características de multipolaridade, pela presença de diversos participantes (Membros) com relevante participação no comércio internacional e pela diversidade qualitativa do intercâmbio comercial, levando à conclusão de que nenhum país pode prescindir de nele participar, revelando inafastável interdependência no fluxo comercial. Nesse sentido, faz-se referência ao Anexo A, o qual contém dados com base nos quais se pode concluir pela existência de outros países com poderio econômico suficiente para contrabalançar os EUA, como a União Europeia, a China e o Japão. Referência também se faz ao sub-capítulo VI.B.3.c abaixo, que contém

poder está amplamente disperso, de modo que não tem o menor sentido falar em unipolaridade, em multipolaridade ou em hegemonia." Nye (2002), p. 79.

489 "While the assumption of American hegemony works well in the security realm [nota de rodapé omitida] it is far from clear whether such an assumption is accurate when thinking about the global political economy. As a share of the global economy, the United States had more power and fewer peer competitors in 1945 than at any point during the current era of globalization - yet no scholar would claim that global policy harmonization was stronger back then. This fact highlights another weakness of the hegemony assumption: the belief that military power, or even productive power, is sufficiently fungible to affect outcomes in the global political economy. [nota de rodapé omitida] Even in realms where American power currently appears preeminent, there are coding disputes." (Drezner (2007), p. 23). 
uma discussão sobre os elementos de poderio nacional a serem considerados no âmbito da "área-tema" de comércio internacional e com base em que se oferece uma classificação de diferentes Membros da OMC de acordo com suas capacidades, sendo que, em tal classificação, a União Europeia, a China e o Japão aparecem como Membros fortes, ao lado dos EUA.

Ademais, há que se ressaltar que a multipolaridade já se faz refletir na operação das negociações mantidas no âmbito da OMC como amplamente documentado. ${ }^{490}$

Conclui-se, portanto, que o regime internacional do comércio internacional se estrutura sob uma multipolaridade. As implicações dessa conclusão são relevantes. Conforme anteriormente exposto, Snyder indica que, dada a multipolaridade, não é possível prever ex ante as possibilidades de alinhamento decorrentes da estrutura, na medida em que as possibilidades de alinhamento se avolumam, assemelhando-se a um jogo de $N$-pessoas ( $N$-person game), ou seja, um jogo de vários jogadores, dentro da matriz de Dilema dos Prisioneiros (teoria dos jogos). ${ }^{491}$

\section{Unidades}

No contexto do SSC/OMC, as unidades são os 153 Membros da OMC. São eles quem podem exigir uns dos outros o estrito cumprimento das obrigações e compromissos assumidos no âmbito do Acordo da OMC, mediante requerimento ao OSC de estabelecimento de consultas (ESC, Artigo 4), instauração de painel (ESC, Artigo 6,) e, ao final, autorização para aplicação de contramedidas (retaliação) ao OSC (GATT 1994, Artigo XXIII, e ESC, Artigo 22). Estabelecido o painel, com a habilitação de terceiras partes, poder-se-á delimitar o universo das unidades para demandante(s), demandado(s) e

\footnotetext{
$490 \quad$ "The world that the WTO was created to govern has been changing rapidly, and, unlike many other international organizations, the WTO has proved unusually responsive to these changes. The most important of these changes has been the shift in the economic balance of power, with the emergence of the new powers that have come to be popularly known as the BRICs. Unlike other organizations, such as the IMF, the World Bank or the UN Security Council, that have been slow to adapt their decision-making structures to reflect these ground-level changes, the WTO has welcomed Brazil, China and India (the BICs) into the core of its decision-making. Moreover, many of these institutional changes within the organization are not a knee-jerk reaction to the financial and economic crisis, but predate it. As a result, the WTO today looks quite different from the 'rich man's club' of the General Agreement on Tariffs and Trade (GATT), which was dominated by the old Quad (EU, US, Canada and Japan)." (Narlikar (2010)).

$491 \quad$ Vide nota de rodapé 430 e texto que a acompanha.
} 
terceira(s) parte(s). Essa delimitação será particularmente importante na análise que se seguirá.

\section{Relacionamentos}

O terceiro fator sistêmico da formação de alianças, dentro da sistematização de Glenn Snyder consiste nos Relacionamentos. ${ }^{492}$ Trata-se da situação de contexto de um determinado comportamento entre duas unidades. Justamente por tratar de uma situação específica acerca do comportamento entre duas unidades, seu exame há que se dar considerando uma situação fática precisa. Não obstante, é possível tecer alguns comentários gerais preliminares acerca dos elementos de Relacionamentos (alinhamentos $e$ alianças; interesses comuns ou conflitantes; capacidades; e interdependência), tendo em vista o contexto do SSC/OMC.

\section{a) Alianças e alinhamentos}

Como indicado anteriormente, ${ }^{493}$ para Snyder, alianças e alinhamentos são variáveis preeminentes entre as variáveis relacionais, pois marcam as linhas de amizade ou inimizade, determinando o tipo de relacionamento entre determinadas unidades (adversário, aliado ou indiferente). Encerram expectativas quanto ao tipo de conduta por parte de outras unidades, dentro de futuras interações (oposição, apoio, neutralidade).

Nesse ponto, toma-se o conceito de "alianças", relembrado por Snyder, ${ }^{494}$ isto é, como acordos formais ou tratados entre sujeitos de direito internacional público destinados a produzir efeitos jurídicos (como, por exemplo, a assunção de compromissos e obrigações). ${ }^{495}$

\footnotetext{
$492 \quad$ Vide nota de rodapé 433 e texto que a acompanha.

$493 \quad$ Vide nota de rodapé 434 e texto que a acompanha.

$494 \quad$ Snyder (1997), p. 4.

495 Amaral Jr. (2008), p. 47: “A importância e o significado de que se revestem os tratados exige solenidade para a sua celebração, representada pela exigência de forma escrita. Os acordos entre Estados soberanos, que em geral comportam consequências de grande alcance para as respectivas sociedades, não pode circunscrever-se ao mero ajuste verbal. É lógica, portanto, a obediência à forma escrita como meio de conferir maior segurança e estabilidade às relações entre as partes."
} 
Igualmente, toma-se o conceito de "alinhamentos" como toda forma de relação entre dois países que não se firme por meio de uma aliança. Nesse ponto, remete-se ao conceito de "atos concertados não convencionais" (ou gentlemen's agreements ou nonbinding agreements $)^{496}$ que Nguyen Quoc Dinh definiu como "instrumentos procedentes de uma negociação entre pessoas habilitadas a vincular o Estado e chamadas a enquadrar as relações destes, sem para tal ter um efeito obrigatório", podendo adotar variadas formas, como comunicados comuns, declarações, cartas, códigos de conduta, combinações, memorandos, atos finais, protocolos, entre outros. ${ }^{497}$

Decerto que esses instrumentos se diferenciam de resoluções de organizações internacionais e de tratados, alinhando-se com Dihn, não parece ser o caso de se especificar os tipos de atos concertados não convencionais que seriam passíveis de observação, na medida em que "qualquer que seja o interesse intelectual destas classificações, elas não poderiam ocultar a unidade da noção do acto concertado não convencional do ponto de vista jurídico" ${ }^{498}$ E tal unidade da noção do ato concertado não convencional é justamente que "[t]ais atos não acarretam obrigações internacionais, mas simplesmente a expectativa de que os participantes agirão em conformidade com as posições expressas", como salienta Amaral Jr. ${ }^{499}$

Aqui cabe um ponto distintivo. A opção por se definir um corte de alinhamento com base no conceito de atos concertados não convencionais se deve à tênue separação entre os conceitos de "alinhamentos" e "interesses". Como poderá ser observado na próxima seção, a existência de interesses convergentes ou conflitantes entre determinados Membros da OMC pode acelerar, retardar ou inibir a formação de determinada aliança. Nesse sentido, a adoção de um critério para definição de “alinhamentos" permitirá distingui-los de eventuais "interesses convergentes" eventualmente existentes entre dois Membros. Com isso, espera-se atribuir uma classificação mais precisa na definição das situações de formação de alianças sob análise.

$496 \quad$ Amaral Jr. observa que "[O] tratado se distingue do gentlemen's agreement, acordo firmado entre chefes de Estado e de governo, de caráter moral, que não dispõe de força juridical obrigatória. Resulta da confiança mútua entre os pactuantes, fator que, por si só, engendra fundada esperança de que se cumprirão as promessas efetuadas." (Ibid., p. 48).

497 Dinh (2002), pp. 394-395.

$498 \quad$ Ibid., p. 396

$499 \quad$ Amaral Jr. (2008). 
Postas essas definições, no tocante a alianças, deve-se perquirir sobre a existência de acordos comerciais entre determinados Membros sob consideração e se tal existência teria o condão de acelerar, retardar ou inibir a formação de determinada aliança visando à aplicação de contramedidas coletivas.

Nessa linha, não parece haver dúvida de que acordos relativos a comércio internacional (trade agreements) devam ser considerados em tal exame, por se tratar de tratados estabelecidos na mesma "área-tema". Ganham relevância, assim, os acordos estabelecendo uniões aduaneiras ou áreas de livre comércio, no âmbito do Artigo XXIV do GATT 1994. Seguindo o mesmo raciocínio de distinção entre "áreas-temas", explorada anteriormente, parece ser o caso de se excluir da análise tratados relacionados a outras “áreas-temas”. A “área-tema” de segurança requer comentários adicionais, todavia.

Ficou devidamente caracterizada a distinção entre "áreas-temas", posicionando-se as questões de segurança internacional no tabuleiro superior do "xadrez tri-dimensional" de Joseph Nye, a configurar o que usualmente se refere como "alta política" ("high politics"). ${ }^{500}$ Nesse contexto, exclui-se a possibilidade de um país se utilizar de capacidades disponíveis em uma dimensão para atingir objetivos em outra. Ou seja, não se vislumbra - nem se perquire - de um determinado país vir a pretender fazer uso da força para resolver um contencioso comercial na OMC. Não há registro de tentativas dessa natureza. A questão então passa a ser se seria possível um determinado Membro utilizar-se da possibilidade de aplicar contramedidas coletivas contra outro Membro, com quem mantenha uma tensão militar - ou esteja em conflito armado. Não se deve excluir tal possibilidade, mas análise de tal natureza extrapolaria os limites deste trabalho, por exigir uma análise das ligações (linkages) entre as diversas "áreas-temas". Para se evitar um tratamento excessivamente hermético, define-se que se analisarão tão-somente os tratados firmados entre determinados Membros havidos na "área-tema" de comércio internacional, a não ser que se constate uma situação de conflito armado.

Estabelecido isso, a questão a ser respondida é se o fato de dois Membros serem signatários de um tratado comercial influencia eventual estratégia de participação de coalizão com ou contra o outro.

$500 \quad$ Vide nota de rodapé 487 e texto que a acompanha. 
A formação de uniões aduaneiras ou de áreas de livre comércio por Membros da OMC é permitida pelo GATT 1994 (Artigo XXIV:5), a despeito da regra basilar da NaçãoMais-Favorecida (Artigo I, GATT 1994), cujo objetivo é garantir tratamento igualitário entre os Membros da $\mathrm{OMC}$ no tocante às obrigações e concessões assumidas pelos demais. Ainda assim, devem os Membros submeter os tratados de formação de uniões aduaneiras ou de áreas de livre comércio ao escrutínio da $\mathrm{OMC}$, para verificação de sua compatibilidade com a normativa multilateral (Artigo 7, GATT 1994), embora tal exame raramente seja empreendido.

Dessa feita, já há muito se constata a proliferação de tratados comerciais, em um fenômeno que Jagdish Bhagwati denominou de "Cumbuca de Espaguete" ("Spaghetti Bowl"), dada a multiplicidade de acordos bilaterais ou plurilaterais firmados entre os diversos Membros da OMC. ${ }^{501}$ A crítica de Bhagwati é no sentido de que tais acordos (preferenciais) de comércio teriam por efeito reduzir os benefícios visados pela normativa multilateral, criando áreas de tratamento preferencial, erodindo o sistema. Críticas à parte, dada a multiplicidade dos acordos comerciais existentes, ${ }^{502}$ as situações específicas deverão ser tratadas oportunamente.

O efeito de determinados tratados comerciais sobre a propensão de determinados Membros a participarem de contramedidas coletivas contra parceiros comerciais pode ser inicialmente verificado a partir da própria existência de contenciosos entre Membros participantes de um mesmo acordo comercial.

Por exemplo, pode-se citar a situação entre Brasil e Argentina. Embora participantes do MERCOSUL, isso não impediu que o Brasil requeresse perante o OSC a instauração de um painel visando a analisar a compatibilidade de medidas antidumping impostos sobre as importações na Argentina de frango salgado originário do Brasil. ${ }^{503} \mathrm{O}$ requerimento culminou na circulação de relatório por um painel que identificou que a

\footnotetext{
$501 \quad$ Vide Bhagwati (2002).

502 Em 31 de julho de 2010, 474 acordos regionais de comércio haviam sido notificados à OMC, 283 dos quais estavam em vigor (http://www.wto.org/english/tratop_e/region_e/region_e.htm, visitado em 22 de janeiro de 2011).

503 Argentina - Definitive Anti-Dumping Duties on Poultry from Brazil [DS241], iniciada em 7 de novembro de 2001.
} 
medida antidumping em questão era incompatível com uma série de dispositivos do Acordo Antidumping. Da mesma forma, mais recentemente, a participação de ambos no MERCOSUL não impediu que a Argentina requeresse a abertura de consultas com o Brasil para discutir medidas antidumping aplicadas pelo Brasil no tocante a importações de resinas originárias da Argentina. ${ }^{504}$ Nesse caso, todavia, o contencioso não chegou ao seu término, tendo as partes atingido a uma "solução mutuamente satisfatória". Ou seja, a participação de ambos os países no MERCOSUL não impediu a instalação de um contencioso entre eles.

Igualmente, a existência do NAFTA, formado com EUA, Canadá e México, não impediu que EUA e Canadá travassem por anos um contencioso a respeito das importações nos EUA de softwood lumber, produto que foi protagonista de diferentes contenciosos ao longo dos últimos anos. ${ }^{505}$ Aliás, a lista de contenciosos tendo EUA e Canadá em posições opostas é relevante. ${ }^{506}$ Também há que se chamar a atenção para o contencioso mantido

504 Brazil - Anti-dumping Measures on Imports of Certain Resins from Argentina [DS355], iniciada em 26 de dezembro de 2006.

$505 \quad$ United States of America - Preliminary Determinations with Respect to Certain Softwood Lumber from Canada [DS236], iniciada em 21 de agosto de 2001, United States of America - Provisional AntiDumping Measure on Imports of Certain Softwood Lumber from Canada [DS247], iniciada em 6 de março de 2002, United States of America - Final Countervailing Duty Determination with respect to certain Softwood Lumber from Canada [DS257], iniciada em 3 de maio de 2002, United States of America - Final Dumping Determination on Softwood Lumber from Canada [DS264], iniciada em 13 de setembro de 2002.

506 Canada - Certain Measures Concerning Periodicals [DS31], iniciada em 11 de março de 1996, Canada - Measures Affecting the Importation of Milk and the Exportation of Dairy Products [DS103], iniciada em 8 de outubro de 1997, United States of America - Certain Measures Affecting the Import of Cattle, Swine and Grain from Canada [DS144], iniciada em 25 de setembro de 1998, United States of America - Countervailing Duty Investigation with respect to Live Cattle from Canada [DS167], iniciada em 19 de março de 1999, Canada - Term of Patent Protection [DS170], iniciada em 6 de maio de 1999, United States of America - Reclassification of Certain Sugar Syrups [DS180], iniciada em 6 de setembro de 1999, United States of America - Measures Treating Export Restraints as Subsidies [DS194], iniciada em 19 de maio de 2000, United States of America - Section 129(c)(1) of the Uruguay Round Agreements Act [DS221], iniciada em 17 de janeiro de 2001, United States of America - Continued Dumping and Subsidy Offset Act of 2000 [DS234], iniciada em 21 de maio de 2001, Canada-Measures Relating to Exports of Wheat and Treatment of Imported Grain [DS276], iniciada em 17 de dezembro de 2002, United States of America Investigation of the International Trade Commission in Softwood Lumber from Canada [DS277], iniciada em 20 de dezembro de 2002, United States of America - Determination of the International Trade Commission in Hard Red Spring Wheat from Canada [DS310], iniciada em 8 de abril de 2004, United States of AmericaReviews of Countervailing Duty on Softwood Lumber from Canada [DS311], iniciada em 14 de abril de 2004, Canada - Provisional Anti-Dumping and Countervailing Duties on Grain Corn from the United States [DS338], iniciada em 17 de março de 2006, United States of America - Subsidies and Other Domestic Support for Corn and Other Agricultural Products [DS357], iniciada em 8 de janeiro de 2007, United States of America - Certain Country of Origin Labelling (Cool) Requirements [DS384], iniciada em $1^{\circ} \mathrm{de}$ dezembro de 2008. 
entre EUA e México no tocante às importações no México de xarope com alta concentração de frutose originário dos EUA. ${ }^{507}$

A menção a esses dois acordos regionais serve para ilustrar que a existência de um acordo regional entre dois Membros não necessariamente se traduz em influência (positiva ou negativa) sobre uma estratégia de questionar medidas comerciais do outro - ou, no limite, de participar de uma coalizão com ou contra o outro para aplicação de contramedidas. A análise dos efeitos de eventuais alianças deverá necessariamente ser feita caso-a-caso.

Quanto aos alinhamentos, a questão a ser verificada é se eventuais alinhamentos no âmbito das negociações da Rodada Doha do Desenvolvimento poderiam influenciar (positiva ou negativamente) a formação de coalizões para aplicação de contramedidas. Por exemplo, pode-se citar o caso de Brasil e Índia que, nos últimos anos, vêm liderando o G20 nas negociações voltadas à conclusão da rodada. Provavelmente, tal posicionamento poderia levar a uma certa indisposição desses Membros em participar de uma retaliação coletiva contra o outro, em razão de interesses comuns objeto de negociação.

Todavia, para evitar confusão entre os conceitos de alinhamento e de interesses (embora todo alinhamento tenha algum interesse comum subjacente), para fins de análise de alinhamentos, deve se considerar como existente quando devidamente documentado (mediante a assinatura de ato concertado não convencional), mantendo-se coerência com a discussão anteriormente desenvolvida. Nesse ponto, pode-se identificar eventuais alinhamentos também por "sub-área-tema", ou seja, se determinado posicionamento em uma negociação sobre agricultura poderia influenciar (positiva ou negativamente) a formação da coalizão. Tal qual o exame das alianças, a análise de eventuais alinhamentos deverá se dar de maneira casuística.

$507 \quad$ Mexico - Anti-Dumping Investigation of High-Fructose Corn Syrup (HFCS) from the United States [DS132], iniciada em 8 de maio de 1998. 


\section{b) Interesses}

Recapitulando a tipologia sobre interesses, Snyder classifica os interesses a partir dos seguintes critérios: (i) valores subjacentes: referentes a valores intrínsecos ou estratégicos; (ii) direção: comuns ou conflitantes; (iii) intensidade: intensos, moderados ou leves; e (iv) especificidade: sistêmicos ou específicos. ${ }^{508}$

No âmbito do SSC/OMC, por se tratar de uma relação controvertida, antagônica, submetida a um processo de solução administrada pelo OSC, a posição de interesses conflitantes entre os Membros demandante e demandado é evidente: trata-se de interesses: relativos a valores intrínsecos (a liberação comercial); conflitantes (dado seu antagonismo); intensos (como comprova o pedido de instauração de um painel perante o OSC); e específicos (por se concentrarem em uma questão jurídico-comercial determinada).

A posição dos interesses das terceiras partes, por sua vez, pode ser identificada a partir de exame das razões indicadas pelas próprias terceiras partes ao OSC para se habilitarem como tais nos contenciosos.

Com efeito, a participação de terceiras partes nos contenciosos perante o $\mathrm{SSC} / \mathrm{OMC}$ tem base legal nos artigos 4.11, 10.2 e 17.4 do ESC, sendo o texto de seu Artigo 10.1 revelador a respeito: "The interests of the parties to a dispute and those other Members under a covered agreement at issue in the dispute shall be fully taken into account during the panel process".

No estágio inicial do contencioso, na fase de consultas (Artigo 4), qualquer Membro detendo "interesse comercial substancial ("substantial trade interest" - Artigo 4.11) poderá notificar os Membros que realizarão consultas e o OSC de sua intenção de participar das negociações. Havendo concordância por parte do Membro demandado de que tal pedido procede ("that the claim of substantial interest is well-founded"), sua junção como terceira parte terá acontecido. Havendo rejeição de tal pedido, aquele Membro ficará

$508 \quad$ Vide Capítulo V.F.2 acima. 
livre para pedir consultas autônomas com o Membro demandado, o que levará potencialmente ao estabelecimento de um painel autônomo. ${ }^{509}$

Estabelecido o Painel (Artigo 6, ESC), o ESC reduz o nível do requisito necessário para participação de uma terceira parte, requerendo apenas que o Membro detenha um "interesse substancial” ("substantial interest") na questão objeto do contencioso. Em tal condição, após reservar seus direitos de terceira parte, poderá se fazer ouvir sobre a questão, incluindo a apresentação de manifestações próprias ("written submissions" Artigo 10.2), embora sem direito de apelar ao Órgão de Apelação (Artigo 17.4).

Nesse sentido, no tocante à caracterização de determinados interesses como interesses substanciais a justificar a participação como terceira parte, o Órgão de Apelação afirmou o entendimento de que se trata de uma questão cabível somente ao Membro ("selfregulating"), ${ }^{510}$ conforme relatórios do Órgão de Apelação nos casos CE - Bananas III e Korea - Definitive Safeguard Measure on Imports of Certain Dairy Products ("Coreia Laticínios”). O Órgão de Apelação colocou a caracterização de determinado interesse comercial ("substantial interest") a justificar a intervenção como terceira parte na mesma linha que a caracterização de interesse de um Membro para requerer a instalação de um painel (desnecessidade de se demonstrar interesse "econômico" ou "jurídico", sendo tal interesse "self-regulating"). ${ }^{511}$ Interessante notar que, ao decidir tal questão no âmbito do

$509 \quad$ ESC, Artigo 4.11: "Whenever a Member other than the consulting Members considers that it has a substantial trade interest in consultations being held pursuant to paragraph 1 of Article XXII of GATT 1994, paragraph 1 of Article XXII of GATS, or the corresponding provisions in other covered agreements [nota de rodapé omitida], such Member may notify the consulting Members and the DSB, within 10 days after the date of the circulation of the request for consultations under said Article, of its desire to be joined in the consultations. Such Member shall be joined in the consultations, provided that the Member to which the request for consultations was addressed agrees that the claim of substantial interest is well-founded. In that event they shall so inform the DSB. If the request to be joined in the consultations is not accepted, the applicant Member shall be free to request consultations under paragraph 1 of Article XXII or paragraph 1 of Article XXIII of GATT 1994, paragraph 1 of Article XXII or paragraph 1 of Article XXIII" of GATS, or the corresponding provisions in other covered agreements."

510 "In EC-Bananas, the Appellate Body stated that the need for a 'legal interest' could not be implied in the DSU or in any other provisions of the WTO Agreement and that Members were expected to be largely self-regulating in deciding whether any DSU procedure would be 'fruitful'. We cannot read in the DSU any requirement for an 'economic interest'. We also note the provisions of Article 3.8 of the DSU, pursuant to which nullification and impairment is presumed once violation is established." (Coreia - Laticínios, relatório do Órgão de Apelação, 14 de dezembro de 1999, para. 160).

$511 \quad$ "We agree with the Panel that "neither Article 3.3 nor 3.7 of the DSU nor any other provision of the $D S U$ contain any explicit requirement that a Member must have a "legal interest" as a prerequisite for requesting a panel'. We do not accept that the need for a 'legal interest' is implied in the DSU or in any other provision of the WTO Agreement. It is true that under Article 4.11 of the DSU, a Member wishing to join in multiple consultations must have 'a substantial trade interest', and that under Article 10.2 of the 
caso CE - Bananas III, o Órgão de Apelação confirmou a assertiva do Painel de que “(...) with the increased interdependence of the global economy, (...) Members have a greater stake in enforcing WTO rules than in the past since any deviation from the negotiated balance of rights and obligations is more likely than ever to affect them, directly or indirectly". 512

Ao reservar os direitos de terceira parte, um Membro deve fazê-lo por escrito ao OSC, oportunidade em que arrola os interesses substanciais a que se refere. Ao fazê-lo, tem sido prática dos Membros indicar expressamente o interesse comercial afetado, ou simplesmente fazer referência a "interesses sistêmicos" no tocante ao processamento da demanda. Busch e Reinhardt (2006) veem na indicação de "interesses sistêmicos" uma sinalização do Membro de que levará para a apreciação do Painel questões mais amplas de fundo, de caráter axiomático, a refletir um interesse mais aprofundado do Membro na disputa, baseado em preocupações fundamentais, do que simplesmente uma tentativa de ganhar acesso ao mercado objeto da disputa. ${ }^{513}$ Embora faça sentido o comentário de Busch e Reinhardt (2006), confirmaremos a classificação de um interesse sistêmico como "intenso" somente após examinar na situação fática em questão se tal classificação corresponde (na dúvida, classificar-se-á como “intenso”).

A Tabela 12, constante do Anexo B, sumariza, no tocante às onze arbitragens anteriormente mencionadas, quais foram os tipos de interesses invocados pelas terceiraspartes que reservaram seus direitos em cada uma das demandas originárias, às quais se fará

DSU, a third party must have 'a substantial interest' in the matter before a panel. But neither of these provisions in the DSU, nor anything else in the WTO Agreement, provides a basis for asserting that parties to the dispute have to meet any similar standard. Yet, we do not believe that this is dispositive of whether, in this case, the United States has 'standing' to bring claims under the GATT 1994." (CE - Bananas III, para. 132).

512 Ibid., para. 136 (citando relatório do Painel).

$513 \quad$ "This is not to say that systemic interests substitute for a lack of a substantial trade interest. On the contrary, reference to systemic interests is typically an indication that third parties intend to raise broaderand potentially more axiomatic - concerns, and in this regard systemic interests are the most tangible signal that the third parties are keenly interested in the dispute. In a case concerning oil tubular goods, for example, China, Japan, and Taiwan all cited systemic interests, as well as substantial trade interests. Indeed, while all three countries are sizable producers of the good in dispute (hence their substantial trade interests), they also had fundamental concerns about the case, as suggested by the forty-eight pages dedicated to their submissions in the final panel report. [nota de rodapé omitida] Canada, by contrast, participated as a third party in a dispute over a product the country scarcely imports, desiccated coconut; yet despite this lack of a substantial trade interest, it did not invoke a systemic interest. [nota de rodapé omitida] Our point is that, by citing a systemic interest, members are signaling a deep interest in the case and not simply trying to gain access as a third party in a dispute in which they lack a clear economic interest. " (Busch e Reinhardt (2006), p. 452). 
referência adiante. Não se exclui a possibilidade de um Membro deter interesse (não externado) no resultado de um determinado contencioso. Todavia, perquirir sobre tal interesse, sem qualquer evidência, seria um tanto especulativo, o que se evitará fazer neste trabalho.

\section{c) Capacidades}

Como exposto anteriormente, a tradição realista tem como um dos pontos de sua análise o cômputo das capacidades, do poderio nacional, mediante análise de determinados elementos, os chamados "elementos do poderio nacional”, na acepção de Morgenthau. Em sua clássica obra, em que tratou unicamente de questões de segurança internacional, Morgenthau listou os seguintes fatores de poderio nacional:

1. Geografia: insularidade, extensão, auto-suficiência alimentar e acesso a matérias-primas, com destaque atualmente para o petróleo;

2. Capacidade industrial: essencialmente, capacidade de produção armamentista;

3. Preparação militar: tecnologia, com destaque atualmente para a tecnologia nuclear, liderança, quantidade e qualidade das forças armadas;

4. População: distribuição entre as nações e tendências (aumento mais lento, envelhecimento);

5. Caráter nacional;

6. Moral nacional, qualidade da sociedade e do governo;

7. Qualidade da diplomacia; e

8. Qualidade do governo, incluindo adequação entre meios e políticas, equilíbrio entre recursos disponíveis e apoio popular interno e externo.

Pelas razões exploradas acima, o exame das capacidades das unidades deve se dar no âmbito da "área-tema" em questão (seção B.1.b, sobre "Polaridade"), conforme Keohane (1995), Keohane e Nye (1977) e Nye (2002) (cumpre observar que Snyder não adentra essa questão, pois sua análise foca questões de segurança militar, daí se buscar apoio nos autores que analisaram o tema). 
Para eleição dos itens constitutivos do poderio nacional no âmbito da "área-tema" de comércio internacional, partiu-se da lista de Morgenthau (1947), a qual inclui os fatores listados acima. A partir de tal lista, excluíram-se os itens diretamente ligados a questões de segurança militar (geografia; capacidade industrial; preparação militar), bem como outros itens de difícil mensuração, dado seu elevado grau de subjetividade (caráter nacional; moral nacional).

Embora não tratando exatamente dessa questão, Drezner (2007) aponta que a identificação de "grandes poderes" é possível por meio do tamanho de seu mercado interno e sua vulnerabilidade a choques externos. ${ }^{514}$ Por essa razão, incluiu-se como fator componente do poderio nacional de comércio internacional os dados de PIB nominal, PIB (PPP) e PIB per capita, por serem expressão do tamanho do mercado interno. Também se optou por coletar dados que mostrem a participação e exposição do Membro ao comércio internacional (participação no comércio internacional de mercadorias; importações totais e exportações totais), bem como referências que permitissem verificar o grau de exposição do Membro ao comércio internacional (participação no comércio no PIB [nominal] e participação no comércio no PIB [PPP]). Feitas essas adaptações, propõe-se a seguinte lista:
1. População;
2. PIB nominal;
3. PIB (PPP);
4. PIB per capita;
5. Participação no comércio internacional de mercadorias;
6. Importações totais;
7. Exportações totais;
8. Participação do comércio no PIB (nominal);
9. Participação do comércio no PIB (PPP).

$514 \quad$ "Great powers are defined by their internal market size and reduced vulnerability to external shocks. This endows them with the necessary market power and coercive power to alter the incentives for weaker states. For the empirical cases that will be evaluated in this book, the only great powers are the United States and the European Union." (Drezner (2007), p. 58). 
Para reunião dos dados no tocante ao SSC/OMC, primeiramente, identificou-se os "principais usuários" do SSC/OMC, definidos como número de "casos totais" de que tenha participado (inclui participação como terceira parte, pois, como se viu, serve de indicativo de interesse na solução do contencioso, constituindo um sinal inicial de possível participação na retaliação coletiva), constantes da Tabela 3 abaixo:

\section{Tabela 3 - Maiores Usuários do SSC/OMC - "Casos Totais"}

\begin{tabular}{|c|c|c|c|c|c|}
\hline Membro & Demandante & Demandado & Terceira Parte & $\begin{array}{c}\text { Total } \\
\text { (como parte) }\end{array}$ & $\begin{array}{c}\text { Total } \\
\text { (Casos Totais) } \\
\end{array}$ \\
\hline EUA & 96 & 110 & 80 & 206 & 286 \\
\hline UE & 82 & 70 & 98 & 152 & 250 \\
\hline Japão & 14 & 15 & 102 & 29 & 131 \\
\hline Canadá & 33 & 16 & 71 & 49 & 120 \\
\hline Índia & 19 & 20 & 63 & 39 & 102 \\
\hline Brasil & 25 & 14 & 61 & 39 & 100 \\
\hline China & 7 & 20 & 71 & 27 & 98 \\
\hline México & 21 & 14 & 55 & 35 & 90 \\
\hline Coreia do Sul & 14 & 14 & 53 & 28 & 81 \\
\hline Australia & 7 & 10 & 55 & 17 & 72 \\
\hline Argentina & 15 & 17 & 30 & 32 & 62 \\
\hline Tailândia & 13 & 3 & 45 & 16 & 61 \\
\hline Taipé Chinesa & 3 & 0 & 55 & 3 & 58 \\
\hline Chile & 10 & 13 & 26 & 23 & 49 \\
\hline Turquia & 2 & 8 & 28 & 10 & 38 \\
\hline Noruega & 4 & 0 & 33 & 4 & 37 \\
\hline Nova Zelândia & 7 & 0 & 30 & 7 & 37 \\
\hline Colômbia & 5 & 3 & 25 & 8 & 33 \\
\hline Guatemala & 8 & 2 & 16 & 10 & 26 \\
\hline Equador & 3 & 3 & 13 & 6 & 19 \\
\hline Venezuela & 1 & 2 & 16 & 3 & 19 \\
\hline Honduras & 7 & 0 & 12 & 7 & 19 \\
\hline Peru & 3 & 4 & 10 & 7 & 17 \\
\hline Filipinas & 5 & 6 & 5 & 11 & 16 \\
\hline Indonésia & 5 & 4 & 4 & 9 & 13 \\
\hline Hungria & 5 & 2 & 2 & 7 & 9 \\
\hline $\begin{array}{l}\text { Antígua } \\
\text { Barbuda }\end{array}$ & 1 & 0 & 0 & 1 & 1 \\
\hline
\end{tabular}

Fonte: World Trade Organization (2010).

Acrescentou-se a esses Membros todos os Membros que tenham participado como demandantes, demandados ou terceiras partes nas onze arbitragens do Artigo 22.6, chegando-se à Tabela 11 constante do Anexo A, a qual consolida os dados de poderio 
nacional no âmbito do SSC/OMC, com base em dados obtidos da $\mathrm{OMC}^{515}$ e do Fundo Monetário Internacional (“FMI"). 516

Há que se ressaltar que, ao se fazer a análise de uma situação específica, deve-se levar em conta também o conceito de capacidade relativa (asset specificity) mencionado por Snyder. ${ }^{517}$ Ou seja, importa saber o poderio nacional de determinado Membro, mas interessa ainda mais perquirir o poderio nacional de determinado Membro em relação ao Membro em questão. Esse conceito é de grande relevância pois, no caso do SSC/OMC, a detenção de um ativo específico pode significar que determinado Membro tenha um ativo (o fluxo comercial de um determinado produto) de relevância ao Membro demandado, cuja restrição poderá ter um impacto eficaz em termos de induzir ao cumprimento. Dessa feita, ao se analisar uma situação fática, será necessário verificar se existem um ou alguns fluxos comerciais relevantes que poderiam ser classificados como um ativo específico no tocante ao Membro demandado.

\section{d) Aliança-Dependência (Interdependência)}

Finalmente, no tocante à aliança-dependência, tem-se que a aliança-dependência está para o aliado como a capacidade está para o adversário: tem a ver com a capacidade relativa do aliado ou do adversário de causar dano a uma determinada unidade. Quanto a uma coalizão, a dependência a uma determinada aliança se perfaz no grau de dano provocado pela deserção total ou parcial (não cumprimento de obrigações) da aliança por um aliado. ${ }^{518}$ Por sua vez, o grau de dependência dentro da coalizão determinará o seu grau de coesão ou fragilidade: os aliados tenderão a ser mais dependentes um do outro quão maior for a ameaça enfrentada, quanto mais um depender do outro para fazer frente à ameaça e quão menos atraentes ou disponíveis forem as alternativas. Quando os aliados forem assimetricamente dependentes, o menos dependente, em geral, exercerá a maior influência. Inversamente, quando a aliança for simétrica, provavelmente será difícil exercer

\footnotetext{
$515 \quad$ World Trade Organization (2010).

$516 \quad$ International Monetary Fund (2010).

517 Vide nota de rodapé 440 e texto que a acompanha.

$518 \quad$ Snyder (1997), p. 31.
} 
influência sobre o outro. Por fim, quando for elevada a dependência mútua, a aliança será coesa; quando baixa, a aliança será frágil. ${ }^{519}$

A ideia de aliança-dependência tem relação direta com questões intra-aliança, anteriormente tratadas em Olson e Zeckhauser (1966), um texto a que Snyder empresta significativa relevância no desenvolvimento de sua própria teoria, classificando-o como "seminal". ${ }^{520}$ Dada a relevância que Snyder dá a tal texto, parece ser apropriado relembrar alguns de seus conceitos, destacando-se os seguintes pontos: eventuais disparidades entre a distribuição de capacidades afetam a coesão e a liderança no âmbito da aliança (quanto maior for a assimetria na distribuição de capacidades, maior a chance de o líder ditar a direção política da aliança). Trata-se justamente da questão da aliança-dependência, apontada por Snyder.

Nesse diapasão, Olson e Zeckhauser (1966) já apontavam para os perigos do "abandono" (risco de ser abandonado no caso de conflito), tema que foi incorporado na teoria de Snyder, expressamente. Com efeito, como ressaltou Snyder, "[T]he existence of alternatives and the uncertainty of alignment generate an endemic distrust among allies. All must be concerned about the danger of being abandoned; hence all must take care that the ally does not become disillusioned and restless". ${ }^{521}$ Ao assim comentar, Snyder socorre-se de Kenneth Waltz, que via uma relação de causa e efeito entre a flexibilidade de um alinhamento e a adoção de uma tratamento rígido intra-aliança. ${ }^{522}$ Como notou Snyder, "[T] discourage the ally from defecting, one is constrained to frame one's own policy, to some extent, to suit the ally's interests". 523

No contexto do SSC/OMC, quer nos parecer que o problema do abandono, eventualmente derivado de uma relação desequilibrada de aliança-dependência, em determinadas situações, poderá colocar em risco esforços para o estabelecimento de um sistema de contramedidas multilateral. Ou seja, havendo muita dependência de um potencial membro em relação à capacidade relativa de um potencial aliado - ou muitas alternativas disponíveis ao Membro que se pretenda participe da retaliação coletiva -,

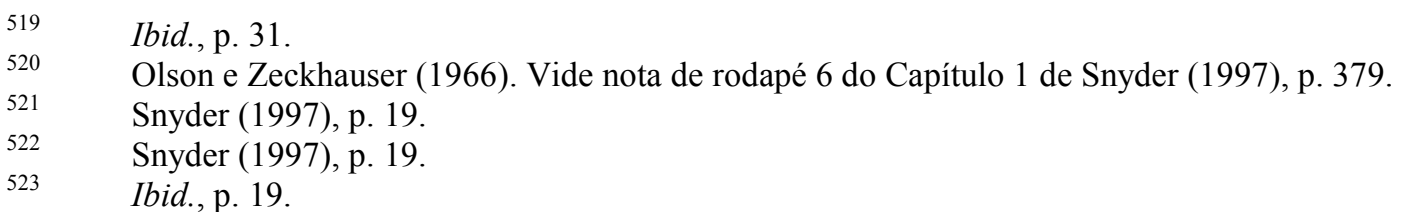


deverá se perquirir sobre a adequação, para determinadas situações, da adoção de um sistema de contramedidas coletivo de caráter obrigatório. Esses conceitos serão retomados, quando do exame das onze arbitragens do Artigo 22.6.

\section{Interação}

A análise da interação se perfaz em nada mais do que uma análise sistematizada dos quatro elementos sistêmicos de uma teoria de formação de alianças: Estrutura, Unidades (Atributos), Relacionamentos, Interação e Resultados, no caso, proposta por Snyder para que seja feita a partir um Jogo de Aliança, em uma matriz conhecida de Dilema dos Prisioneiros. ${ }^{524}$

Tal análise somente pode ser feita a partir de uma situação fática específica. Não obstante, recapitula-se apenas que, como sustenta Snyder, o poder de barganha relativo a adversários dependerá das percepções das capacidades comparativas e da intensidade relativa de seus interesses conflitantes. ${ }^{525}$ No caso de aliados, o poder de barganha derivará das percepções sobre sua dependência relativa, compromissos e intensidade de interesses sobre o objeto da barganha.

\section{Formação de Alianças}

A discussão de Snyder finaliza com uma análise do processo de formação de alianças, oportunidade em que realça a necessidade de se apurar o valor de uma determinada aliança, bem como analisar a estrutura de incentivos sistêmicos e nãosistêmicos para formação de coalizões.

O cálculo da formação de uma coalizão se baseia em uma série de elementos, cuja utilidade neste trabalho é afastada, considerando seu caráter eminentemente numérico, pela limitação de dados e pela opção, neste trabalho, por uma abordagem mais teórica, tendo em vista ser esta a primeira aproximação da teoria de formação de alianças com o SSC/OMC.

\footnotetext{
$524 \quad$ Vide nota de rodapé 449 e texto que a acompanha.

$525 \quad$ Snyder (1997), p. 37.
} 
No tocante à estrutura de incentivos, ressalta-se que a estrutura de incentivos sistêmicos (multipolaridade e número de unidades) foi devidamente abordada na seção anterior, restando analisar a estrutura de incentivos não-sistêmicos identificados por Glenn H. Snyder (vide seção V.F acima) no âmbito do SSC/OMC.

Nesse ponto, a estrutura de incentivos não-sistêmicos se baseia na diferença de capacidades e nos conflitos de interesse, com base em que foi possível a Snyder considerar diferentes situações, refletidas nos Quadros 1 a 4 acima, bem como extrair algumas conclusões importantes acerca do processo de formação de alianças. ${ }^{526}$ Tomando por base tais achados de Snyder, pode-se chegar a algumas primeiras proposições referentes à formação de alianças, no contexto do SSC/OMC:

1. Estrutura: desigualdade de capacidades gera algum grau de alinhamento, independente da existência de coalizões. [Comentário referente SSC/OMC: consistente com afirmações da literatura e de propostas apresentadas ao Grupo Negociador, trata-se de uma proposição que incentiva a criação de um sistema de retaliação coletiva justamente nas situações em que haja desigualdade de capacidades, para preservação do equilibrio de poder];

a. Países mais fracos ${ }^{527}$ se defenderão uns aos outros e terão a expectativa de serem defendidos por estados mais fortes contra outros mais fortes. [Comentário referente SSC/OMC: essa proposição corrobora a percepção inicial da utilidade e necessidade de um sistema de retaliação coletiva para benefício de Membros fracos; indica suporte à propensão de neutralidade por parte dos Membros fracos, diante de uma participação de Membros mais fortes nos custos da sanção, limitando sua participação quando possa fazer alguma diferença para alterar o resultado do conflito. Neste caso, os

\footnotetext{
$526 \quad$ Vide nota de rodapé 458 e texto que a acompanha.

527 Utiliza-se os adjetivos "fraco" e "forte" acompanhados do advérbio de intensidade "mais", dado o conceito de capacidade relativa, anteriormente exposto.
} 
interesses dos Membros mais fracos deverão ser intensos para que participem de uma coalizão]; ${ }^{528}$

b. As alianças mais valiosas são aquelas entre países mais fracos ameaçados por mais fortes. [Comentário referente SSC/OMC: proposição faz sentido dentro da estrutura do SSC/OMC, pois são os Membros fracos que já expressamente requereram a instituição de um sistema de retaliação coletiva. Por outro lado, alianças entre Membros mais fracos evitariam problemas de aliança-dependência, em que um desequilíbrio na distribuição de capacidades poderia criar uma instabilidade em sua manutenção];

c. As alianças menos valiosas são aquelas entre dois países mais fortes contra um mais fraco. [Comentário referente SSC/OMC: essa proposição indica que a retaliação coletiva não deve ser autorizada em casos envolvendo Membro demandante forte contra Membro demandado fraco, haja vista o descompasso de capacidades, também em razão dos problemas de aliançadependência anteriormente apontados.];

d. Quando um país mais forte se alia a um mais fraco, quem mais se beneficia é o país mais fraco, se o oponente for mais fraco. [Comentário referente SSC/OMC: essa proposição parece indicar a utilidade da retaliação coletiva em situações envolvendo Membros de diferentes tamanhos, sendo o demandante um Membro mais fraco, o demandado de tamanho médio e uma terceira parte mais forte. Comparativamente, provavelmente não seria eficaz uma eventual retaliação por parte do Membro mais fraco em relação a um Membro mediano, mas mais fraco que o mais forte];

e. Quando um país mais forte se alia a um mais fraco, o país mais forte se beneficiará mais se o oponente for mais forte. ${ }^{529}$ [Comentário referente

\footnotetext{
$528 \quad$ Rothstein (1962) foi quem primeiramente indicou que estados pequenos somente se aliam quando identificam a possibilidade de influírem no resultado do conflito. Glenn Snyder parece adotar implicitamente essa proposição de Rothstein (1962), daí sua incorporação acima. Snyder faz expressa menção ao trabalho Rothstein (1962), como uma obra clássica sobre o tema. Vide Snyder (1997), p. 2, n. 5.
} 
SSC/OMC: essa proposição parece indicar um incentivo para que um Membro mais forte se alie a um Membro demandante fraco, contra um Membro demandado forte, desde que necessário para a formação de uma "menor coalizão vencedora", em respeito ao "princípio do tamanho", 530 abordado por Snyder; de outro lado, indica um problema de "free rider" por parte do Membro mais fraco em participar dos custos da sanção, preferindo manter neutralidade, por não poder interferir no resultado do conflito ; $^{531}$

2. Alianças formais geram tanto benefícios quanto custos e isso modifica expectativas de alinhamento. Custos e benefícios variarão de acordos com as condições préaliança (existência de interesses comuns ou conflitantes).

a. Interesses comuns: alianças compatíveis com interesses comuns valem mais do que outras sem tal situação, porque os custos de transação são menores. [Comentário referente SSC/OMC: no âmbito do SSC/OMC, (i) a existência de interesse comum - identificável pela participação como terceira parte, por exemplo - será um fator propulsor da formação de uma aliança visando a aplicação de uma retaliação coletiva; (ii) nesse sentido, com base no item 1.a acima, quando um Membro mais forte tiver interesse estratégico em determinado assunto sob disputa, um Membro mais fraco poderá ter a expectativa de ser socorrido por aquele Membro mais forte, contra o Membro mais forte demandado];

b. Interesses conflitantes: a pré-existência de interesses conflitantes tem relação com os valores de dissuasão, defesa e preclusão, de forma que, em uma situação envolvendo três unidades:

\footnotetext{
$529 \quad$ Snyder (1997), p. 60. Adiante, Snyder acrescenta que: "[T]he strength of incentives to ally and the determinacy of partners will depend on the intensity of conflicts and the degree of strength inequalities, and whether these variables are mutually reinforcing or opposed. When conflicts are severe and particularly when the same states are in conflict on several issues, the drive to ally formally will be strong and the likely partners will be quite clear. When conflicts are mild and nonreinforcing and strength differences are small, there may be little more pressure to ally than in our initial model of pure anarchy, or the probable identity of allies will be quite ambiguous." (Snyder (1997), p. 62).

$530 \quad$ Vide notas de rodapé 387 e 457 e textos que as acompanham.

531 Vide nota de rodapé 528 e texto que a acompanha.
} 
i. A pré-existência de conflito pode reforçar a expectativa de ser assistido por uma das unidades (pois o conflito com uma pode levála a se aliar com a outra) [Comentário referente SSC/OMC: no âmbito do SSC, a existência de outro contencioso tendo por objeto a mesma medida objeto do contencioso em questão indica uma probabilidade maior de formação de coalizão para aplicação de retaliação coletiva. Aliás, a aprovação do OSC para aplicação em um contencioso análogo em andamento equivalerá a uma situação de feixes de retaliações bilaterais, cujo efeito seria semelhante à de uma retaliação coletiva];

ii. A pré-existência de interesses conflitantes pode diminuir a expectativa de ser assistido por uma das unidades (pois o conflito com o outro pode lhe dar a segurança de ser protegido por um) [Comentário referente SSC/OMC: no âmbito do SSC, a existência de interesses conflitantes exclui a possibilidade de o Membro demandado participar da retaliação coletiva contra ele mesmo ou contra um outro Membro demandado que tenha interesse alinhado com o seu];

iii. A intensidade dos interesses conflitantes pré-existentes pode significar um propulsor de um eventual alinhamento. [Comentário referente SSC/OMC: quando se chega ao final do contencioso, ou seja, no momento da aplicação da retaliação, a intensidade do conflito se encontra no ponto quase máximo, superado apenas por sua própria aplicação]; ${ }^{.32}$

3. Barganha - alternativas disponíveis: a formação de uma coalizão dependerá das alternativas disponíveis ao país em consideração, levando em conta se a coalizão é possivel (resulta em situação melhor do que o status quo) e competitiva (proporciona mais valor para todos seus membros do que outras alianças), tendo as

532 Assertiva consistente com a proposição de Snyder de que a formação da aliança somente se dá quando o adversário estiver prestes a atingir seu objetivo. Vide nota de rodapé 456 e texto que a acompanha. 
demais coalizões relevantes (aliança não-competitiva que influencia a barganha entre e através das possibilidades competitivas) em mente.

Feitos os apontamentos acima, parte-se agora para análise das situações fáticas objeto das onze arbitragens do Artigo 22.6 do ESC, descritas na seção II.D acima.

\section{Aplicação da Teoria de Formação de Alianças às Situações Fáticas das Onze Arbitragens do Artigo 22.6 do ESC}

A aplicação de contramedidas é precedida de uma arbitragem cujo objeto é determinar o nível de suspensão de concessões ou outras obrigações por parte do Membro demandante em relação ao demandado. Trata-se da chamada arbitragem do Artigo 22.6 do ESC. Somente após a autorização do pelo OSC, e baseado no relatório do árbitro, é que poderá o Membro demandante aplicar as contramedidas, mediante suspensão de concessões ou outras obrigações feitas ao Membro demandado.

Até o momento, dos 418 contenciosos levados ao SSC/OMC, somente onze (11) casos chegaram até o estágio limite de aplicação de contramedidas/retaliação $(2,63 \%$ de todos os casos). Por terem chegado a tal estágio limite, as situações fáticas neles observadas podem servir de referência para a análise ora empreendida. Com efeito, o sistema de solução de controvérsias proporcionou uma série de oportunidades para que os Membros em consideração chegassem a uma solução mutuamente satisfatória, mediante a realização de consultas prévias, de consultas obrigatórias precedentes à instalação de um painel, a análise do relatório do painel, sua reavaliação pelo Órgão de Apelação, sem falar nas variadas possibilidades de arbitragens para determinar o período razoável de tempo para implementação da decisão do OSC (Artigo 21.3.c), para determinar a conformidade da implementação com os termos da decisão do OSC (Artigo 21.5) e, afinal, a discussão em torno da possibilidade de aplicação de contramedidas, sua forma e extensão (Artigo 22.6). Tendo percorrido todo esse procedimento, resta evidente se tratar de uma situação limite de não-cumprimento, tornando sua análise a mais próxima das situações observáveis em que a retaliação coletiva poderá operar. 
Partindo-se da premissa de uma estrutura anárquica e multipolar, o próximo passo é identificar as unidades sob consideração. Para tanto, a Tabela 4 a seguir compila os dados de cada uma das arbitragens, indicando o nome do contencioso, os Membros demandantes, demandados e as terceiras partes que indicaram interesse em participar do contencioso:

\section{Tabela 4 - Unidades das Onze Arbitragens}

\begin{tabular}{|c|c|c|c|}
\hline Contencioso & $\begin{array}{c}\text { Membro(s) } \\
\text { demandante(s) }\end{array}$ & $\begin{array}{c}\text { Membro(s) } \\
\text { demandado(s) }\end{array}$ & Terceiras Partes \\
\hline $\begin{array}{l}\text { CE-Bananas } \\
\text { (DS27) }\end{array}$ & $\begin{array}{l}\text { Equador } \\
\text { Guatemala } \\
\text { Honduras } \\
\text { México } \\
\text { EUA }\end{array}$ & $\mathrm{CE}$ & $\begin{array}{c}\text { Belize; Camerões; Canadá; } \\
\text { Colômbia; Costa Rica; } \\
\text { Dominica; República } \\
\text { Dominicana; Gana; Grenada; } \\
\text { Índia; Jamaica; Japão; Nicarágua } \\
\text { Filipinas; Santa Lúcia; São } \\
\text { Vincentee Grenada; Senegal; } \\
\text { Surinâme; Venezuela; Costa do } \\
\text { Marfim; Brasil; Madagascar; } \\
\text { Panamá } \\
\end{array}$ \\
\hline $\begin{array}{l}\text { CE - Hormônios } \\
\text { (DS26/DS48) }\end{array}$ & $\begin{array}{c}\text { EUA (DS26) } \\
\text { Canadá (DS48) }\end{array}$ & $\mathrm{CE}$ & $\begin{array}{l}\text { Austrália; Canadá; Nova } \\
\text { Zelândia; Noruega* }\end{array}$ \\
\hline $\begin{array}{l}\text { Brasil-Aeronaves } \\
\text { (DS46) }\end{array}$ & Canadá & Brasil & $\begin{array}{c}\text { Austrália; UE; } \\
\text { Coreia do Sul; EUA }\end{array}$ \\
\hline $\begin{array}{l}\text { Canadá - Aeronaves } \\
\text { (DS222) }\end{array}$ & Canadá & Brasil & Austrália; UE; Índia; EUA \\
\hline $\begin{array}{l}E U A-F S C \\
\text { (DS108) }\end{array}$ & $\mathrm{CE}$ & EUA & $\begin{array}{c}\text { Austrália; Barbados; Brasil; } \\
\text { Canadá; China; Índia; Jamaica; } \\
\text { Japão }\end{array}$ \\
\hline $\begin{array}{l}\text { EUA-Lei } \\
\text { Antidumping de } 1916 \\
\text { (DS136) }\end{array}$ & $\mathrm{CE}$ & EUA & Índia; Japão; México \\
\hline $\begin{array}{l}\text { EUA - Emenda Byrd } \\
\text { (DS217/DS234) }\end{array}$ & $\begin{array}{c}\text { Austrália (DS217) } \\
\text { Brasil (DS217) } \\
\text { Chile (DS217) } \\
\text { CE (DS217) } \\
\text { Índia (DS217) } \\
\text { Indonésia (DS217) } \\
\text { Japão (DS217) } \\
\text { Coreia do Sul } \\
\text { (DS217) } \\
\text { Tailândia (DS217) } \\
\text { Canadá (DS234) } \\
\text { México (DS234) }\end{array}$ & EUA & $\begin{array}{l}\text { Argentina; Canadá;Costa Rica; } \\
\text { Hong Kong, China; Israel; } \\
\text { México; Noruega }\end{array}$ \\
\hline $\begin{array}{l}\text { EUA - Algodão } \\
\text { (DS267) }\end{array}$ & Brasil & EUA & $\begin{array}{l}\text { Argentina; Austrália; Benin; } \\
\text { Canadá; Chade; China; Taipé } \\
\text { Chinesa; CE; Índia; Nova } \\
\text { Zelândia; Paquistão; Paraguai; } \\
\text { Venezuela; Japão; Tailândia }\end{array}$ \\
\hline $\begin{array}{l}\text { EUA - Jogos e Apostas } \\
\text { (DS285) }\end{array}$ & Antígua e Barbuda & EUA & $\begin{array}{l}\text { Canadá; Taipé Chinesa; CE; } \\
\text { Japão; México; China }\end{array}$ \\
\hline
\end{tabular}

* EUA e Canadá participam reciprocamente como terceira parte nos contenciosos trazidos pelo outro. Informação omitida pois o interesse como Membro demandante já se encontra registrado. 
Identificadas as Unidades, é possível agrupar as situações fáticas de forma a se identificarem situações em que haja desigualdade de capacidades, com base nas capacidades das unidades constantes da Tabela 4 acima.

Nesse sentido, partindo-se dos dados de capacidades mencionados anteriormente, foi possível classificar as unidades sob consideração ("maiores usuários" do SSC/OMC e Membros participantes das arbitragens do Artigo 22.6, conforme indicado na seção "Capacidades" acima) em três grandes grupos de Membros: os "fracos", os "médios" e os "fortes".

Para tanto, primeiramente, preparou-se um gráfico das unidades tendo no eixo $\mathrm{X}$ a capacidade "População (em milhões de pessoas)" e no eixo Y a capacidade "PIB per capita 2010 PPP (US\$ bilhões)", do que se resultou uma dispersão das unidades conforme a confluência de tais variáveis. O resultado encontra-se refletido no Gráfico 1 abaixo:

Gráfico 1 - População x PIB (PPP)

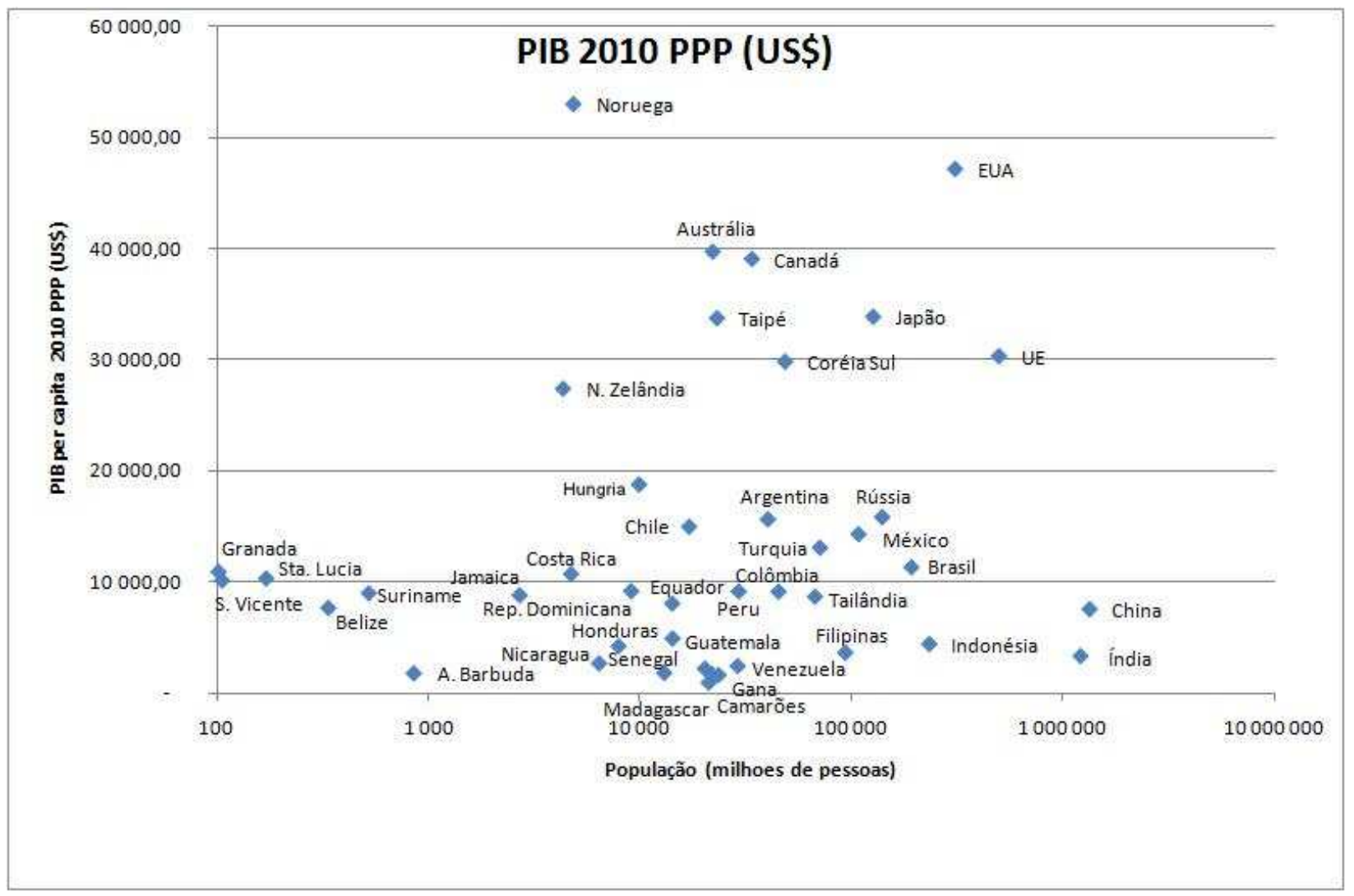

Fonte: International Monetary Fund (2010). 
Em segundo lugar, preparou-se um segundo gráfico intitulado “Comércio Agregado (US\$ bilhões)", tendo no eixo X as unidades consideradas (maiores usuários do SSC/OMC e Membros participantes das arbitragens do Artigo 22.6) e, no eixo Y, valores para refletir o comércio agregado em bilhões de dólares norte-americanos (comércio agregado é o resultado da soma das seguintes capacidades de cada unidade, constantes da Tabela 9 no Anexo A: Exportação de Mercadoria, Importação de Mercadoria, Exportação de Serviços e Importação de Serviços). O resultado, em ordem decrescente foi o seguinte: União Europeia, EUA, China, Japão, Coreia do Sul, Canadá, Rússia, México, Índia, Taipé Chinesa, Austrália, Brasil, Tailândia, Turquia, Indonésia, Noruega, Hungria, Venezuela, Chile, Argentina, Filipinas, Colômbia, Nova Zelândia, Peru, Equador, Costa Rica, Guatemala, República Dominicana, Costa do Marfim, Gana, Honduras, Senegal, Camarões, Jamaica, Nicarágua, Madagascar, Suriname, Beliza, Antígua e Barbuda, Dominica, Santa Lúcia, São Vicente e Granadinas e Granada, conforme refletido no Gráfico 2 abaixo:

Gráfico 2 - Comércio Agregado

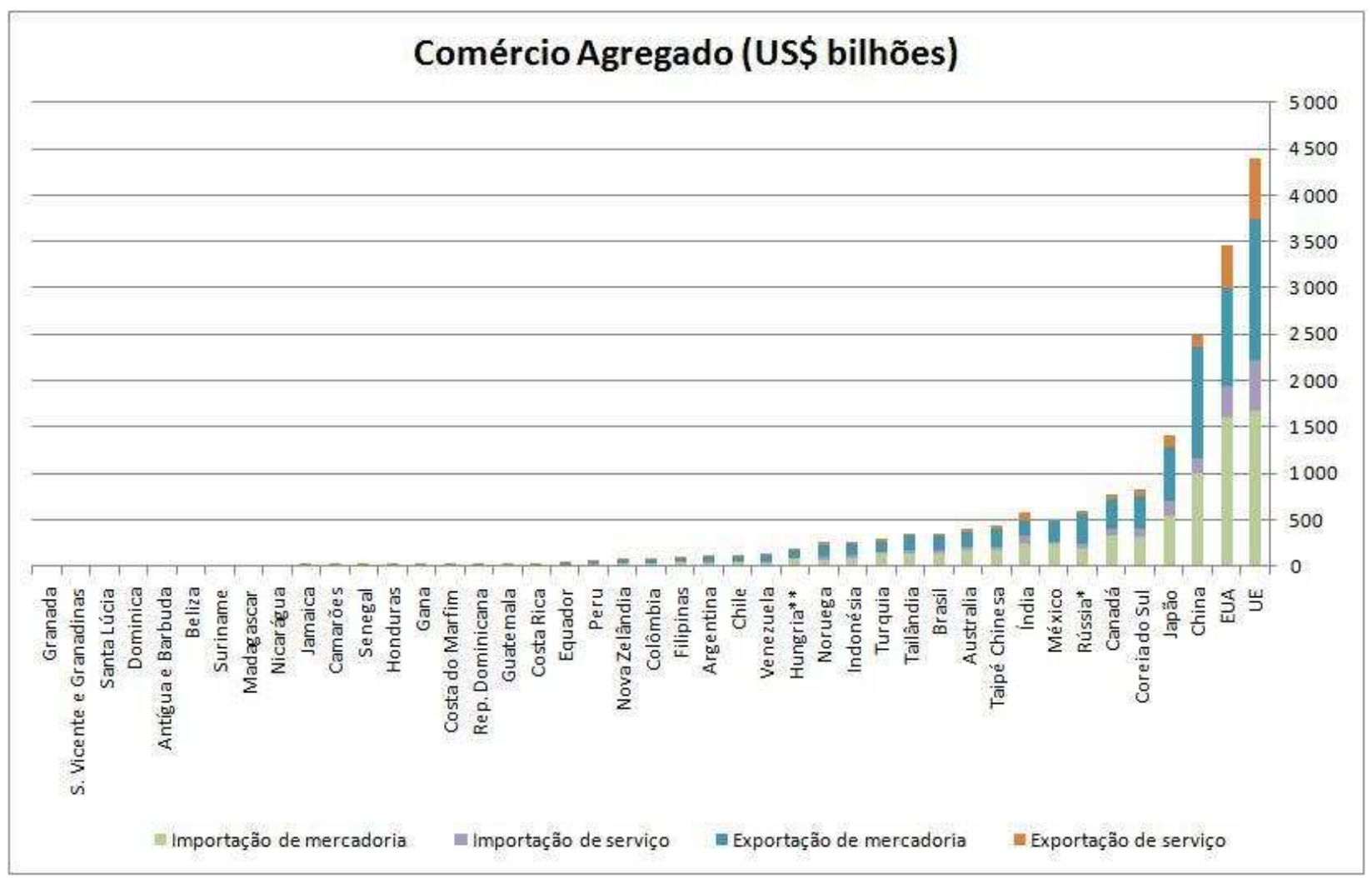

Fonte: World Trade Organization (2010). 
Ao final, combinaram-se os resultados obtidos nos Gráficos 1 e 2 acima, em um gráfico de dispersão, tendo no eixo X os valores de "Comércio Agregado" refletidos no Gráfico 2 (em escala logarítmica) e, no eixo Y, os dados de "PIB 2010 PPP (US\$ bilhões)", com o que foi possível distinguir-se em uma nova dispersão três grupos de Membros: "fracos", "médios" e "fortes".

\section{Gráfico 3 - Distribuição de Capacidades}

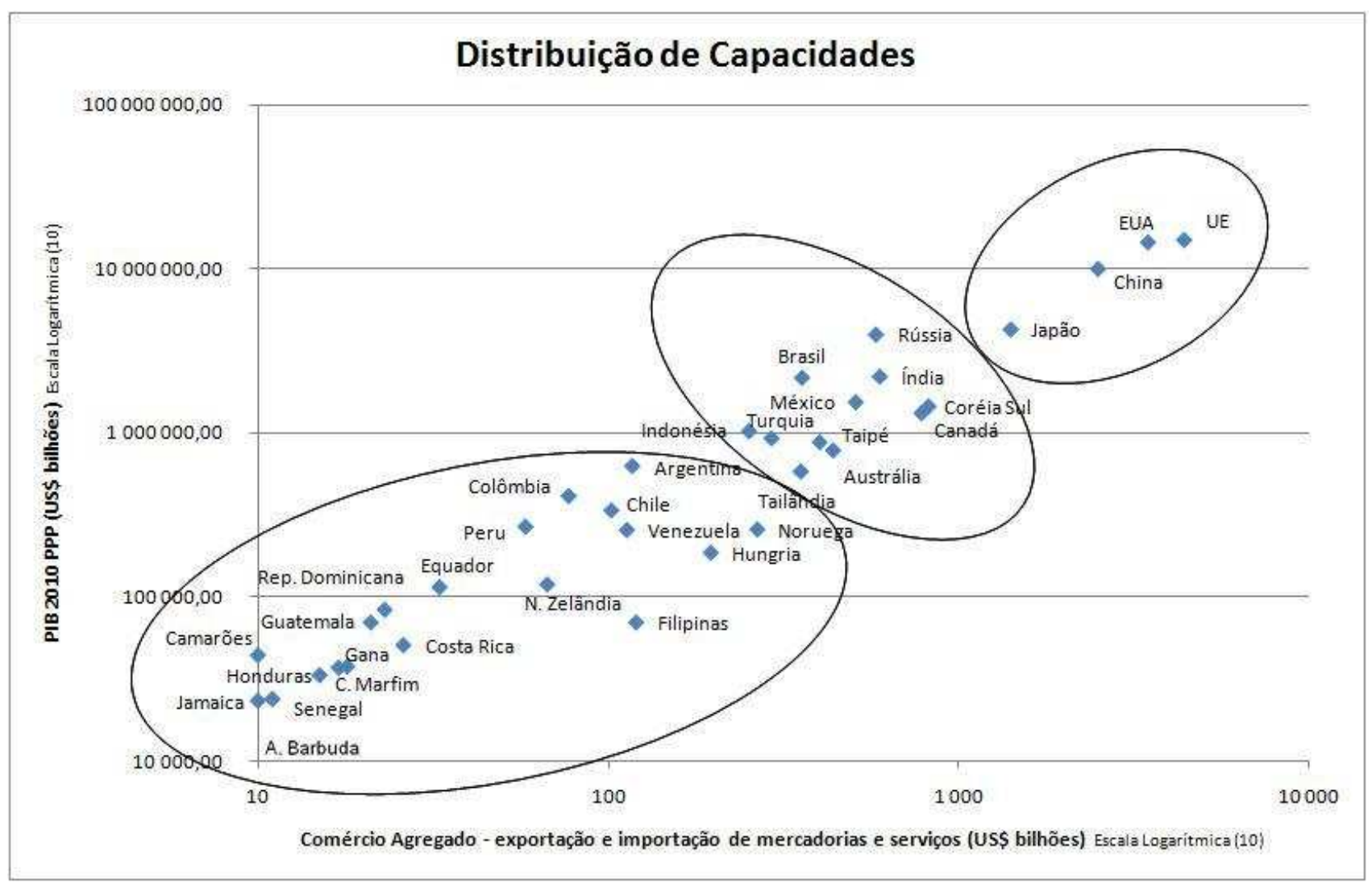

Fontes: World Trade Organization (2010); International Monetary Fund (2010).

A dispersão dos Membros considerados indica um grupo destacado disperso no alto à direita, composto por União Europeia, EUA, China e Japão, o qual se distinguirá como Membros "fortes". Um grupo intermediário, dos Membros "médios", localizados mais ao centro do Gráfico 3, formado por Rússia (que não é Membro), Índia, Coreia do Sul, Canadá (em posição mais próxima ao primeiro grupo), Brasil, México, Austrália, Taipé Chinesa, (em posição intermediária nesse subgrupo), Tailândia, Turquia e Indonésia (já quase tocando o início do terceiro grupo da dispersão). Por fim, identifica-se um terceiro agrupamento, composto pelas demais unidades, iniciado por Argentina, Noruega, Filipinas, Chile, Hungria, Venezuela e Colômbia, seguidos de Peru, Nova Zelândia, Equador, Filipinas, República Dominicana, Guatemala, Costa Rica, Gana, Costa do Marfim, 
Honduras, Camarões, Senegal e Jamaica. Antígua e Barbuda, dada sua pequenez, acabou quase não se refletindo no gráfico, por quase não caber na unidade de medida adotada.

Com base nesse resultado, chega-se à seguinte classificação das unidades, consideradas conforme a distribuição de capacidades (excluiu-se a Rússia por não ser Membro da OMC ainda):

\section{Tabela 5 - Classificação das Unidades/Membros conforme Distribuição de Capacidades}

\begin{tabular}{|c|c|c|}
\hline Fortes & Médios & Fracos* \\
\hline $\begin{array}{c}\text { União Europeia; EUA; China; e } \\
\text { Japão }\end{array}$ & $\begin{array}{l}\text { Índia; Coreia do Sul; Canadá; } \\
\text { Brasil; México; Austrália; Taipe } \\
\text { Chinesa; Tailândia; Turquia e } \\
\text { Indonésia }\end{array}$ & $\begin{array}{l}\text { Argentina; Noruega; Filipinas; } \\
\text { Chile; Hungria; Colômbia; Peru; } \\
\text { Nova Zelândia; Venezuela; } \\
\text { Equador; Guatemala; Honduras; } \\
\text { Antígua e Barbuda; Costa Rica; } \\
\text { Belize; Benin; Camarões; } \\
\text { Dominica; República } \\
\text { Dominicana; Gana; Granada; } \\
\text { Jamaica; Nicarágua; Santa Lúcia; } \\
\text { São Vicente e Granada; Senegal; } \\
\text { Suriname; Costa do Marfim; } \\
\text { Madagascar; Panamá; Paquistão; } \\
\text { Paraguai; e Israel. }\end{array}$ \\
\hline
\end{tabular}

* Adicionou-se os países-ACPs que participaram como terceiras partes no contencioso CE - Bananas III.

Considerando a classificação acima, a Tabela 6 abaixo registra o agrupamento das situações das onze arbitragens do Artigo 22.6 para revelar situações de desigualdade de capacidades: $:^{533}$

533 Casos análogos paralelos, ou seja, em que dois Membros tenham requerido a instalação de um painel para verificar a compatibilidade de uma mesma medida de um mesmo Membro demandado, foram agrupados, por corresponder a uma mesma situação fática (casos de CE - Bananas III; CE - Hormônios; e Brasil-Aeronaves/Canadá-Aeronaves). 


\section{Tabela 6 - Classificação das Situações Fáticas conforme \\ Desigualdades de Capacidades}

\begin{tabular}{|c|c|c|c|c|c|c|}
\hline & \multicolumn{6}{|c|}{ Situações Fáticas } \\
\hline & \multicolumn{2}{|c|}{ Forte $x$ Forte } & \multirow{2}{*}{$\begin{array}{l}\text { Médio } x \\
\text { Forte }\end{array}$} & \multirow{2}{*}{$\begin{array}{l}\text { Médio x } \\
\text { Médio }\end{array}$} & \multirow{2}{*}{$\begin{array}{l}\text { Médio x } \\
\text { Fraco }\end{array}$} & \multirow[t]{2}{*}{ Fraco $x$ Forte } \\
\hline & Sem Coalizão & Com Coalizão & & & & \\
\hline \multirow{4}{*}{ 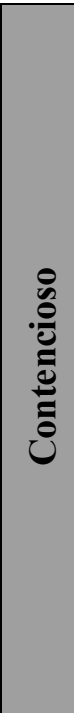 } & $\begin{array}{c}\text { Direitos } \\
\text { Autorais } \\
\text { (CE x EUA) }\end{array}$ & $\begin{array}{c}\text { Hormônios } \\
\text { (EUA + Canadá } \\
\text { x CE) }\end{array}$ & $\begin{array}{l}\text { Algodão } \\
\text { (Brasil x } \\
\text { EUA) }\end{array}$ & $\begin{array}{c}\text { Aviões } \\
\text { (Brasil x } \\
\text { Canadá/ } \\
\text { Canadá x } \\
\text { Brasil) } \\
\end{array}$ & & $\begin{array}{c}\text { Jogose } \\
\text { Apostas } \\
\text { (Antígua e } \\
\text { Barbuda x } \\
\text { EUA) }\end{array}$ \\
\hline & $\begin{array}{c}F S C \\
\text { (CE x EUA) }\end{array}$ & $\begin{array}{c}\text { Bananas } \\
\text { (Equador + CE } \\
\text { x EUA) }\end{array}$ & & & & \\
\hline & & $\begin{array}{c}\text { Lei Antidumping } \\
1916 \\
\text { (CE, Índia, } \\
\text { Japão e México } \\
\text { x EUA) }\end{array}$ & & & & \\
\hline & & $\begin{array}{c}\text { Emenda Byrd } \\
\text { (CE, Brasil, } \\
\text { Canadá e Outros } \\
\text { x EUA) }\end{array}$ & & & & \\
\hline
\end{tabular}

Antes mesmo de adentrar o próximo estágio da análise ("Alianças e Alinhamentos"; e "Interesses"), a classificação acima já permite extrair determinadas conclusões, com base nas proposições de Snyder acerca da formação de alianças.

Em primeiro lugar, contata-se que os casos envolvendo disputas entre Membros fortes (EUA x CE ou CE x EUA) são em geral resolvidos entre tais Membros mais fortes.

A forma mais recorrente de solução é, após aprovada a aplicação de contramedidas, os EUA - diante da ameaça da retaliação - tomarem as medidas necessárias para implementar as recomendações do OSC, conforme EUA - Direitos Autorais, ${ }^{534}$ EUA - Lei Antidumping de $1916^{535}$ e EUA - FSC. ${ }^{536}$ Vale notar que esses três casos requereram modificações legislativas e, para tanto, o envolvimento do Poder Legislativo norteamericano, o que, em grande parte, pode ter sido a causa da demora nas mudanças

\footnotetext{
$534 \quad$ Vide nota de rodapé 105 e texto que a acompanha.

535 Vide nota de rodapé 133 e texto que a acompanha.

$536 \quad$ Vide nota de rodapé 110 e texto que a acompanha.
} 
necessárias nas medidas objeto de disputa, para trazê-las em conformidade com as recomendações do OSC.

EUA - Emenda Byrd destoa do padrão desses três casos, pois há ali uma discordância quanto à conformidade do remédio adotado com as recomendações do OSC, bem como participação de outros Membros retaliantes (embora, também Membros fortes, o Japão, e um médio, o Canadá). Ainda assim, não há sinal de que a ameaça apresentada pelas contramedidas europeias e japonesas sejam ineficazes para induzir os EUA a modificarem a medida objeto da disputa, haja vista que já levaram à aprovação de legislação visando a revogar a medida questionada. De outra parte, aparentemente, as CE se contentaram com a aprovação de um "regulamento-espelho" que, de alguma forma, concedeu algum conforto às empresas europeias porventura sujeitas a direitos antidumping nos EUA. ${ }^{537}$ Seria uma espécie de "solução mutuamente satisfatória" velada.

Nesse diapasão, há que se relembrar a situação vivida no caso EUA - Salvaguardas do $A c ̧ o,{ }^{538}$ o qual reforça a proposição acima, na medida em que as medidas de salvaguardas foram revogadas pelos EUA na véspera da implantação de contramedidas (as chamadas contramedidas "carrossel”) pelas CE contra os EUA, embora sem qualquer referência a elas. ${ }^{539}$

Esses casos em conjunto corroboram a proposição de Snyder de que "desigualdade de capacidades gera algum grau de alinhamento" (item 1 acima); inversamente, havendo igualdade de capacidades, não há incentivos sistêmicos para alinhamento. ${ }^{540}$

\footnotetext{
537 Regulamento (CE) n. $.^{\circ} 673 / 2005$ do Conselho, de 25 de Abril de 2005, que institui direitos aduaneiros adicionais sobre as importações de certos produtos originários dos Estados Unidos da América $538 \quad$ United States - Definitive Safeguard Measures on Imports of Certain Steel Products [DS252], iniciado em 26 de março de 2002.

539 David Sanger, A Blink from the Bush Administration. New York Times, 5 de dezembro de 2003.

$540 \quad$ É interessante notar que William Davey identificou esse mesmo padrão, embora intuitivamente, ao comentar, ainda em 2004, que as contramedidas (suspensão de concessões) parecem ser eficazes quando ameaçadas por um país grande contra outro grande (e também por um grande contra um menor): "There is a more general problem with suspension of concessions. While it seems to work when threatened by a large country against a smaller one, and has worked when implemented by one major power against another, it may not be an effective remedy for a small country (even if it can target sensitive large country sectors such as copyright holders). Moreover, the EC Bananas and EC Hormones cases show that it is not always effective, at least not immediately, between major powers. It should be noted, however, that retaliation by the EC against the US seemed to have a political effect in the FSC case that led to US implementation, even if the significance of the economic impact of the retaliation was not clear. In addition, the EC and others'
} 
Ademais, o caso EUA - Emenda Byrd evidencia que Membros mais fracos (caso de Brasil, Chile, Índia, Coreia e México) preferirão se abster de se aliar (na aplicação de contramedidas) quando presentes Membros mais fortes dispostos a aplicá-las (caso de CE, Japão e Canadá). Corrobora-se com isso a proposição de Snyder de que "Países mais fracos (...) terão a expectativa de serem defendidos por estados mais fortes contra outros mais fortes" (item 1.a acima) e de que "quando um país mais forte se alia a um mais fraco, o país mais forte se beneficiará mais se o oponente for mais forte" (item 1.e acima), na medida em que "indica um problema de "free rider" por parte do Membro mais fraco em participar dos custos da sanção, preferindo manter neutralidade".

O contencioso $C E$ - Hormônios parece representar uma situação especial, diante da contumácia das $\mathrm{CE}$ em não cumprirem a recomendação do OSC de modificar a medida objeto de disputa. Nesse caso, há que se ressaltar, EUA e Canadá, os dois países demandantes com autorização para retaliar, formam, sem qualquer dúvida, uma "menor coalizão vencedora" (conforme princípio do tamanho, expressamente adotado por Snyder), por sobrepujarem as capacidades de comércio internacional das CE. Ainda assim, isso não tem sido suficiente para induzir as CE a cumprirem a recomendação do OSC.

Comparando-se tal situação com outra "menor coalizão vencedora", formada no contencioso CE - Bananas III (em que tanto EUA como Equador estavam habilitados a aplicar contramedidas), nota-se que possivelmente o foco de resistência da mudança não se deva necessariamente a razões comerciais, mas pareça mais atrelado a questões culturais, já que o consumidor europeu é muito sensível à adição de produtos químicos ou não orgânicos em sua alimentação - causando um problema de incapacidade política interna para promover a modificação. ${ }^{541}$

threat of retaliation seemed to work in the US Steel Safeguards case. Nonetheless, occasional inefficacy of suspension of concessions and the unfavorable position in which it leaves developing countries may soon combine to create a serious credibility problem for the system that must be confronted." (Davey (2005), p. 13).

541 William Davey comenta tal relutância: "In the case of the SPS Agreement, it would appear that public concerns over food safety and the impact of those concerns on politicians has been a significant problem that has delayed implementation in SPS cases." (Ibid., p. 11). 
Com efeito, em $C E$ - Bananas III, embora o contencioso tenha tomado décadas para ser resolvido em sua inteireza (possivelmente reflexo da complexa estrutura de tomada de decisões nas $\mathrm{CE}$, do regime de importação envolvido e dos interesses conflitantes dos países-ACP a serem atingidos), ao final, foi implementada mudança na legislação europeia, para o efeito de chegar a uma solução mutuamente acordada entre partes relevantes, sem que para isso tenha sido necessário aplicar contramedidas, seja pelos EUA, seja pelo Equador (no caso, com a autorização inédita para impor retaliação cruzada sobre direitos de propriedade intelectual). ${ }^{542}$ Sinal da força da ameaça da retaliação por parte de outro Membro forte - os EUA -, embora reforçado pelo risco de uma retaliação sobre direitos de propriedade intelectual da parte do Equador.

A proposição de que "desigualdade de capacidades gera algum grau de alinhamento" (item 1 acima) e, inversamente, sua inexistência não gera incentivos próalinhamento, parece também explicar a situação no contencioso travado entre Brasil e Canadá (Brasil-Aeronaves; Canadá-Aeronaves).

Conforme indicado na Tabela 3 acima, Brasil e Canadá encontram-se posicionados como Membros médios e, como tais, mantêm uma equivalência de capacidades, que não parece justificar a necessidade de recurso a qualquer mecanismo de coalizão. O fato de os contenciosos terem se processado normalmente, com acusações de lado a lado, reciprocamente (na melhor forma "tit-for-tat"), ${ }^{543}$ dá mostras da igualdade de forças entre tais países. Tanto é que o resultado final foi a adequacão de programas ao $A S M C$ e a celebração de um acordo mutuamente satisfatório.

Resta então analisar as situações restantes (EUA - Algodão e EUA - Jogos e Apostas) que envolvem as tentativas, respectivamente, de um Membro médio (Brasil) e de um Membro fraco (Antígua e Barbuda), de induzirem um Membro forte (os EUA, em ambos os casos) a cumprir recomendações do OSC. Trata-se exatamente das situações em que se identificam potenciais problemas de enforcement, a possivelmente justificar a adoção de um sistema de retaliação coletiva.

\footnotetext{
$542 \quad$ Vide notas de rodapé 62 e 70 e textos que as acompanham.

$543 \quad$ "Canada did not impose countermeasures against Brazil most likely because Brazil could do the same in the same dispute (export subsidies in regional aircrafts where Bombardier and Embraer, Canadian and Brazilian producers respectively hold a join dominant position in the market)." Bagwell, Mavroidis e Staiger (2004), p. 12.
} 
Em EUA - Algodão, após anos de processamento da disputa, chegou-se a uma solução temporária entre Brasil e EUA, após um bem-sucedido processo de negociação entre os dois países, permeado de estágios processuais e ameaças retaliatórias por parte da diplomacia brasileira. ${ }^{544}$ A questão que se apresenta é se tal mudança só foi possível em razão da ameaça representada pela aplicação de retaliação cruzada por um país médio.

Com efeito, nota-se que, embora aprovada, a retaliação cruzada no caso $C E$ Bananas III não foi necessariamente a força motriz de mudança da medida das CE - mais provavelmente, deve ter sido a co-participação de EUA, um Membro forte com interesses comuns em igual profundidade. Tampouco parece ter sido eficaz no caso EUA-Jogos $e$ Apostas, em que, sem um co-participante (aliado) na aplicação de contramedidas, não há o menor sinal de mudança na medida norte-americana objeto da disputa.

Isso talvez sugira a insuficiência da retaliação cruzada, como aliás adiantado anteriormente, ${ }^{545}$ quando aplicada por Membros fracos, haja vista o reduzido universo de sua possível aplicação, reflexo de seu diminuto mercado interno, uma das principais medidas do poderio nacional na "área-tema" em questão. Corrobora essa hipótese a análise do processo de negociação entre EUA e Brasil, no âmbito de EUA - Algodão, em que se pode observar que os EUA somente se engajaram efetivamente na negociação quando a ameaça de retaliação cruzada se mostrou crível, ou seja, após publicação da Consulta Pública referente à sua aplicação. ${ }^{546}$

Com efeito, os que advogam o reforço da retaliação cruzada, como Grosse RuseKahn (2008), sinalizam que a retaliação cruzada até poderia ter efeitos de geração de bemestar, pelo acesso a tecnologias e possibilidade de fomento às indústrias de produtos genéricos, por exemplo, ou de alta tecnologia. Esse argumento, todavia, olvida que mesmo a geração de tais indústrias depende da capacidade de atrair investimentos, ou, na realidade, de as tecnologias em questão serem capturadas imediatamente por indústrias já

\footnotetext{
$544 \quad$ Vide nota de rodapé 210 e texto que a acompanha.

545 Grosse Ruse-Kahn (2008), pp. 335-339. Vide também a nota de rodapé 288 e texto que a acompanha.

546 Resolução nº 16, de 12 de março 2010, publicada no D.O.U. de 15 de março de 2010.
} 
instaladas - dado o caráter transitório e precário das contramedidas, algo somente plausível em Membros/países médios.

Essa constatação parece nada mais que reforçar a necessidade de instauração de um mecanismo de retaliação coletiva, o qual até poderá abranger suspensão de compromissos ou obrigações em acordos diferentes do objeto da disputa. O caso EUA - Jogos e Apostas parece ser sintomático, nesse sentido, por Antígua e Barbuda (um Membro fraco) ter recebido autorização do OSC para aplicação de contramedidas, incluindo contramedidas sobre direitos de propriedade, sem que os EUA tenham sequer considerado aprovar modificações na medida em questão.

A situação de Antígua e Barbuda em EUA - Jogos e Apostas somente se diferencia da do Equador em $C E$ - Bananas III pela presença de um poder equilibrante, no caso os EUA. A questão então passa a ser justamente: de que tipos de instrumentos o Equador poderia se socorrer na hipótese de ausência de um poder equilibrante como os EUA? Observando-se os casos de coalizão acima indicados (CE - Bananas III; EUA - Lei Antidumping de 1916; EUA - Emenda Byrd), foi justamente a possibilidade de formação de uma "menor coalizão vencedora" que propulsionou a indução ao cumprimento de EUA ou de CE. Isso somente foi possível pelo alinhamento de interesses comuns entre Membros forte, médios e fracos em prol da obtenção do compliance.

Essa constatação equivale a dizer que se identifica em tais circunstâncias um grau elevado de aliança-dependência, sendo a dependência de uma determinada aliança o grau de dano provocado pela deserção total ou parcial (não cumprimento de obrigações) da aliança por um aliado. ${ }^{547}$ Isso posto, a ausência (deserção) de Membros com interesse comum em determinados contenciosos parece sugerir que a solução seja uma obrigatoriedade na participação da retaliação, sem a qual ela não será possível, diante da inexistência de um interesse mínimo por parte de Membros que permitiriam chegar a uma “menor coalizão vencedora”. Essa proposição, aliás, é corroborada pelo axioma Watziano, adotado por Snyder, segundo o qual se identifica uma relação de causa e efeito entre o grau

547 Snyder (1997), p. 31. Vide nota de rodapé 441 e texto que a acompanha. 
de flexibilidade de um alinhamento e a adoção de um tratamento rígido intra-aliança (quanto mais dependente, mais rígida deve ser a estrutura da aliança). ${ }^{548}$

Por suas características peculiares, prosseguir-se-á com a análise desses dois casos (EUA - Jogos e Apostas e CE - Bananas III) agora enfocando, dentro de Relacionamentos, nas "Alianças e Alinhamentos" e nos "Interesses" envolvidos. Adentrar a análise do terceiro e do quarto fatores de formação de alianças em relação a tais contenciosos pode oferecer elementos adicionais acerca da formação de alianças nas situações do SSC/OMC em que pareça necessária (ou seja, aquelas em que um Membro médio ou um Membro fraco pretenda induzir um Membro forte a cumprir uma recomendação do OSC).

O caso $C E$ - Bananas III merece um exame mais detido à luz da teoria de formação de alianças: é certo que tal contencioso foi resolvido mediante um acordo muito festejado; todavia, tal acordo somente foi possível após décadas de processamento do contencioso. A pergunta posta é se a existência de um mecanismo de enforcement mais eficaz poderia conduzir a uma solução mais rápida, sob cuja sombra as CE operariam.

\section{CE - Bananas III}

Inicialmente, verifica-se não haver qualquer acordo entre Equador, Guatemala, Honduras, México e EUA, separadamente, de um lado, e, do outro lado, CE, que tenha impedido a manutenção de conflitos entre si no âmbito da $\mathrm{OMC}$, de que o próprio contencioso constitui óbvia prova. Pelo fato de se posicionarem como demandantes do mesmo contencioso, pode-se classificar os interesses de Equador, Guatemala, Honduras, México e EUA como comuns, intensos e específicos.

Quanto a terceiras partes, ressalta-se, no tocante a "Alianças", a existência do "Acordo de Parceria entre os Estados de África, das Caraíbas e do Pacífico e a Comunidade Europeia e os seus Estados-Membros" (“Acordo de Cotonu”), ${ }^{549}$ precedido

\footnotetext{
$548 \quad$ Vide nota de rodapé 442 e texto que a acompanha.

549 Acordo de Parceria entre os Estados de África, das Caraíbas e do Pacífico e a Comunidade Europeia e os seus Estados-Membros, assinado em Cotonu, em 23 de Junho de 2000.
} 
pela Convenção de Lomé, ${ }^{550}$ o qual estabelecia formas de cooperação entre a CE e os países-ACP (África, Caribe e Pacífico). Por esses acordos, foi estabelecido um tratamento preferencial aos países-ACP no comércio de bananas na União Europeia, o qual foi posteriormente questionado no âmbito deste contencioso. Em vista de tal posição, resta evidente que os países-ACP que ingressaram no contencioso como terceira-parte apresentam uma "aliança" com as CE, com objeto diretamente ligado ao da disputa, que se traduz em interesse comum com as CE, o Membro demandado, e conflitante com os Membros demandantes.

A Tabela 7 abaixo resume a natureza dos interesses invocados pelas terceiras partes para adentrar como tais o contencioso:

Tabela 7 - Interesses Invocados pelas Partes no Caso CE - Bananas III

\begin{tabular}{|c|c|c|c|c|}
\hline Caso: & \multicolumn{4}{|c|}{$C E-$ Bananas III [DS27] } \\
\hline Demandante: & \multicolumn{4}{|c|}{ Equador, Guatemala, Honduras, México, EUA } \\
\hline Demandado: & \multicolumn{4}{|c|}{$\mathrm{CE}$} \\
\hline Terceiras partes: & $\begin{array}{l}\text { Interesses } \\
\text { comerciais }\end{array}$ & $\begin{array}{l}\text { Interesse } \\
\text { sistêmico }\end{array}$ & $\begin{array}{c}\text { Mera reserva de } \\
\text { direitos }\end{array}$ & $\begin{array}{c}\text { Sem } \\
\text { manifestação }\end{array}$ \\
\hline \multicolumn{5}{|c|}{ Terceiras partes pró-CE } \\
\hline Belize & $\mathrm{X}$ & & & \\
\hline Camarões & $\mathrm{X}$ & & & \\
\hline Granada & $\mathrm{X}$ & & & \\
\hline Jamaica & $\mathrm{X}$ & & & \\
\hline Santa Lúcia & $\mathrm{X}$ & & & \\
\hline $\begin{array}{l}\text { São Vicente e } \\
\text { Granadinas }\end{array}$ & $\mathrm{X}$ & & & \\
\hline Senegal & $\mathrm{X}$ & & & \\
\hline Suriname & $\mathrm{X}$ & & & \\
\hline Domínica & $\mathrm{X}$ & & & \\
\hline Costa do Marfim & $\mathrm{X}$ & & & \\
\hline Madagascar & & & & $\mathrm{X}$ \\
\hline \multicolumn{5}{|c|}{ Demais terceiras partes } \\
\hline Canadá & & $\mathrm{X}$ & & \\
\hline Colômbia & $\mathrm{X}$ & & & \\
\hline Costa Rica & $\mathrm{X}$ & & & \\
\hline Rep. Dominicana & $\mathrm{X}$ & & & \\
\hline Gana & $\mathrm{X}$ & & & \\
\hline Japão & & & $\mathrm{X}$ & \\
\hline Nicarágua & $\mathrm{X}$ & & & \\
\hline
\end{tabular}

550 Convenção Comunidade Econômica Europeia-ACP assinada em Lomé em em 28 de fevereiro de 1975, Sucedida pelas Convenções Lomé II (assinada em 31 de outubro de 1979), Lomé III (assinada em dezembro de 1984) e Lomé IV (assinada em 15 de dezembro de 1989). 


\begin{tabular}{|l|c|l|l|l|}
\hline Filipinas & & & $\mathrm{X}$ & \\
\hline Venezuela & $\mathrm{X}$ & & & \\
\hline Brasil & & & & $\mathrm{X}$ \\
\hline Panamá & & & & $\mathrm{X}$ \\
\hline Índia & $\mathrm{X}$ & & & \\
\hline
\end{tabular}

Salvo Madagascar, todas as terceiras partes países-ACP (Belize, Camarões, Granada, Jamaica, Santa Lúcia, São Vicente e Granadinas, Senegal, Suriname, Domínica e Costa do Marfim) indicaram seu interesse como comercial no contencioso, por serem todos produtores e exportadores de bananas, tendo o resultado da disputa representado um prejuízo direto a tal interesse comercial. Em vista de tal indicação, pode-se classificar os interesses de CE e das terceiras-partes países-ACP como comuns, intensos e específicos.

Da mesma forma, as demais terceiras partes que indicaram ter interesses comerciais na disputa podem ser classificadas como tendo interesses conflitantes com o demandado, já que uma decisão contrária ao regime preferencial aos países-ACP significaria uma abertura de parcela significativa do mercado comunitário europeu (Colômbia, Costa Rica, República Dominicana, Gana, Nicarágua, Venezuela e Índia). Com isso, pode-se classificar os interesses de tais terceiras partes com CE como sendo conflitantes, intensos e específicos.

Outros Membros reservaram direitos de terceiras partes, com destaque para o Canadá, que indicou interesse sistêmico, no sentido de se preocupar com a interpretação legal a ser dada a determinadas provisões do GATS, como textualmente indicou em sua manifestação. ${ }^{551}$ Com isso, pode-se classificar seu interesse com CE como sendo neutro, em termos de direção, intensidade e especificidade.

Brasil, Panamá e Japão não indicaram expressamente a natureza de seus interesses no assunto, não se manifestando a respeito (caso dos dois primeiros) ou meramente reservando direitos (caso do último).

$551 \quad$ "Canada had a systemic interest in this matter and believed that a number of issues of systemic interest could be raised in the panel proceedings. One such issue was whether or not the GATS was relevant to this matter. Any conclusions by the panel on this might affect products other than bananas." Manifestação do Canadá [WT/DSB/M/16]. 
Em razão de posicionamentos posteriores por parte de Brasil e Panamá, dois produtores e exportadores de bananas, contrariamente às $\mathrm{CE}$ (tendo inclusive participado como demandantes de painel no âmbito da Decisão Ministerial de Doha, em março/abril de 2005, ao lado de Colômbia, Costa Rica, Equador, Guatemala, Honduras, Nicarágua, Panamá e Venezuela), ${ }^{552}$ pode-se classificar os interesses desses Membros com relação às CE como também sendo conflitantes, intensos e específicos.

Identificam-se, portanto, interesses comuns e conflitantes que, lado a lado, permitem a configuração de dois blocos, um em prol e outro contra o Membro demandado. A configuração seria composta por um grupo liderado pelo demandado, CE, e os diversos países-ACP. Do outro lado, os Membros demandantes centro-americanos, apoiados pelos EUA, tendo outros aliados de porte, como Brasil e Índia, também perfilados.

Dentro das regras do sistema atual, de retaliação bilateral, é permitido somente aos Membros demandantes aplicar retaliação sobre o demandado. Isso implicaria uma configuração de CE (e países-ACP) contra EUA (e países demandantes centroamericanos). Uma situação de igualdade de capacidades, que culminou em um processo moroso e fragmentado, até sua final solução.

Fosse um sistema de retaliação coletiva, possivelmente Brasil e Índia poderiam ter juntado suas capacidades contra as $\mathrm{CE}$, dados seus interesses conflitantes, intensos e específicos, o que, em conjunto com a coalizão formada por EUA e países centroamericanos, levaria à constituição de uma "menor coalizão vencedora". A probabilidade de formação de tal aliança seria elevada, pois, conforme as proposições de Snyder, a formação de tal "menor coalizão vencedora" ajudaria a modificar o resultado do conflito, justificando a participação dos Membros mais fracos (no caso, Membros "médios"), resolvendo o problema do "free rider". Frente a uma ameaça dessa pujança, possivelmente as $\mathrm{CE}$ teriam modificado seu regime de comércio de bananas antes mesmo de se chegar a uma situação limite, como foi a aprovação de retaliação cruzada sobre direitos de propriedade intelectual, requerida pelo Equador.

$552 \quad C E-$ Bananas III. 
Em conclusão, no caso $C E$ - Bananas III, a possibilidade de adoção de um mecanismo de retaliação coletiva teria sido útil para aumentar o poder indutor do SSC/OMC para que as CE adequassem a medida sob disputa às recomendações do OSC. Em tais condições, o mecanismo de retaliação coletiva poderá ser adotado em caráter meramente facultativo: (i) pela pré-existência de interesses comuns, intensos e específicos a propulsionar a formação de uma aliança; (ii) pela elevada capacidade relativa dos Membros formadores da "menor coalizão vencedora"; e (iii) pela possibilidade de os Membros médios influenciarem no resultado do conflito.

\section{EUA - Jogos e Apostas}

A situação fática de EUA - Jogos e Apostas não apresenta complexidades no tocante a "Alianças e Alinhamentos" e "Interesses". Quanto a "alianças", ressalta-se apenas que EUA e Antígua e Barbuda são membros da OEA - Organização dos Estados Unidos. Trata-se de uma filiação, todavia, que não tem impedido seus Membros de manterem contenciosos entre si no SSC/OMC, sendo inúmeros os exemplos que poderiam ser aqui citados. ${ }^{553}$

Quanto às terceiras partes do contencioso (Canadá, Taipé Chinesa, CE, Japão, México e China), sabe-se que Canadá, México, EUA e Antígua e Barbuda são membros da OEA; que EUA, Canadá e México formam o NAFTA; que Antígua e Barbuda e CE são partes do Acordo de Cotonu; e que Antígua e Barbuda e o Reino Unido mantêm um acordo de promoção e proteção de investimentos. ${ }^{554}$ Salvo o Acordo de Cotonu, não nos parece que qualquer desses documentos possa refletir uma aliança que impeça qualquer das partes de se aliar a um lado (com os EUA) ou ao outro (com Antígua e Barbuda). Não foram identificados documentos que indicassem possíveis alinhamentos das terceiras partes com os Membros demandantes ou demandados.

\footnotetext{
553 Além das já citadas controvérsias intra-NAFTA e intra-Mercosul e das controvérsias anteriormente referidas do Brasil contra EUA (EUA - Algodão) e Canadá (Brasil - Aeronaves e Canadá - Aeronaves), há disputas entre os países pequenos do continente americano. O caso mais recente, com a primeira solicitação formal de consultas feita em 15 de outubro de 2010, é Dominican Republic — Safeguard Measures on Imports of Polypropylene Bags and Tubular Fabric, em que são parte demandante Costa Rica [DS414], Guatemala [DS416], Honduras [DS417] e El Salvador [DS418].

$554 \quad$ "Agreement Between the Government of the United Kingdom of Great Britain and Northern Ireland and the Government of Antigua and Barbuda for the Promotion and Protection of Investments", assinado em 12 de junho de 1987.
} 
Quanto aos interesses das terceiras partes, nenhuma delas especificou tratar-se de interesses comerciais ou sistêmicos, que lhes motivaram ingressar como terceira parte em tal contencioso (vide Tabela 12, Anexo B). Não consta das atas das reuniões do OSC em que Antígua e Barbuda requereu a instauração do painel qualquer manifestação de tais partes que pudesse indicar a direção, intensidade e especificidade de seus interesses. Por essas razões, exclui-se o Acordo de Cotonu como uma aliança que pudesse indicar um interesse tal por parte da CE que influenciasse ex ante a formação de alianças neste caso. Há que se registrar, por fim, não ter sido requerido contencioso análogo paralelo por qualquer outro Membro contra os EUA.

Não se identificou, assim, qualquer situação pré-aliança propulsionando ou impedindo a formação de coalizão em prol de Antígua e Barbuda para promover uma retaliação coletiva. Isso parece significar não haver, por parte de qualquer Membro da OMC, uma percepção de que a medida objeto da disputa se traduza em uma ameaça tal a justificar seu engajamento para repartir os custos da sanção com Antígua e Barbuda.

A propósito, no tocante a "aliança-dependência", pela diferença de capacidades com os EUA (são exatamente dois extremos em termos de capacidades, conforme refletido no Gráfico 3), acentuada pela percepção identificada pelos próprios árbitros acerca da baixa capacidade relativa de Antígua e Barbuda em relação aos EUA, ${ }^{555}$ nota-se que Antígua e Barbuda, caso venha a formar uma coalizão, dependerá claramente do(s) demais participante(s) da coalizão para induzir os EUA ao compliance. A aliança-dependência de Antígua e Barbuda neste caso é portanto muito elevada.

Diante desses fatos, quer nos parecer que a adoção de um mecanismo de retaliação coletiva neste caso seria necessária. Mais do que isso, sua adoção neste caso seria de caráter obrigatório: (i) pela baixa capacidade relativa do Membro demandante; (ii) pela inexistência de alianças, alinhamentos ou interesses comuns ou conflitantes que propulsionem uma aliança; e (iii) por sua elevada aliança-dependência, sob pena de simplesmente não se formar uma "menor coalizão vencedora" e se relegar a indução dos EUA ao cumprimento às ínfimas capacidades de Antígua e Barbuda.

$555 \quad$ Vide nota de rodapé 171 e texto que a acompanha. 


\section{Considerações Finais sobre a Utilidade da Aplicação da Teoria de Formação de Alianças, como Desenvolvida por Glenn H. Snyder, sobre o SSC/OMC}

Este Capítulo teve por objeto realizar uma primeira aproximação da teoria de formação de alianças, como desenvolvida por Glenn H. Snyder, com o sistema de solução de controvérsias da OMC.

O resultado da aplicação de tal teoria se mostrou satisfatório, na medida em que, inicialmente, se tenha identificado tratar-se de um sistema estruturado sob a multipolaridade, consistentemente com a hipótese de aplicação originalmente desenvolvida por Snyder. Com efeito, Snyder aplicou sua teoria sobre as situações fáticas de segurança militar referentes às alianças formadas entre países da Europa Central ao final do Século XIX justamente porque tais situações estavam inseridas em um sistema multipolar. Ao se concluir pela existência de uma estrutura multipolar no contexto da "área-tema" de comércio internacional, a aplicação da teoria de formação de alianças passa a ser não somente possível, como necessária, já que, diferentemente de situações insertas em contextos uni ou bipolares, não é possível prever ex ante (ou seja, antes de se analisar os elementos da teoria) as possibilidades de alinhamento.

Adicionalmente, a aplicação da referida teoria permitiu observar de maneira mais objetiva os problemas de desequilíbrio de poder no âmbito do SSC/OMC. Muitos advogam intuitivamente a necessidade de implementação de um sistema de retaliação coletiva no caso de desequilíbrio de poder entre Membros demandante e demandado. A teoria de formação de alianças permitiu perceber as situações em que uma coalizão seria desnecessária, justamente pela ausência de um desequilíbrio de capacidades entre as unidades sob consideração. Em tais circunstâncias, deve-se simplesmente deixar que os próprios Membros (na maioria dos casos, envolvendo contenciosos entre Membros fortes) resolvam a questão entre si. A mesma conclusão vale para contenciosos envolvendo controvérsias entre Membros médios ou controvérsias entre Membros fracos, ou seja, em que as capacidades se mostrem equilibradas. Dessarte, a teoria de formação de alianças permitiu concluir pela desnecessidade de aplicação de retaliação coletiva quando ausente o desequilíbrio de poder, o que se revela uma contribuição de alta relevância. 
De outra parte, a teoria de formação de alianças ofereceu instrumentais úteis que permitiram concluir pela utilidade de um mecanismo de retaliação coletiva no âmbito do $\mathrm{SSC} / \mathrm{OMC}$, justamente para corrigir problemas de desequilíbrio de poder, considerando que o sistema de enforcement ainda se baseia na força (self-help). A teoria de formação de alianças, em sintonia com seus primordiais estudos, permitiu observar as situações em que um mecanismo de retaliação coletiva ajudaria a aplacar ou minimizar problemas de desequilíbrio de poder, oferecendo, mais do que isso, indicações precisas acerca das situações de utilização de um sistema tal.

De fato, com base na teoria de formação de alianças, foi possível concluir haver situações em que um mecanismo de retaliação coletiva deverá ser meramente facultativo, ao passo que, em outras, deverá ser imbuído de caráter obrigatório.

Um mecanismo de retaliação coletiva poderá ter caráter meramente facultativo quando, em uma situação de desequilíbrio de poder: (i) houver outros Membros com interesses comuns, intensos e específicos a propulsionar a formação de uma aliança; e (ii) tais Membros reunirem capacidade relativa suficiente para formar uma "menor coalizão vencedora", juntamente com o Membro demandante. O caso CE - Bananas III retrata exatamente essa situação. Em tal circunstância, bastaria que o ESC facultasse ao OSC, a pedido de um Membro demandante, a possibilidade de permitir a qualquer Membro se candidatar para participar da retaliação coletiva, caso em que se alinharia com o Membro demandante para tal fim. A teoria de formação de alianças permite concluir que a aliança se formaria, sem necessidade de pressão externa (i.e., do OSC), daí seu caráter facultativo neste caso.

O mecanismo de retaliação coletiva deverá ter caráter obrigatório, por sua vez, quando, diante de uma situação de desequilíbrio de poder, (i) seja patente a baixa capacidade relativa do Membro demandante; (ii) não haja Membros com interesses comuns, intensos e específicos a propulsionar a formação de uma aliança com o Membro demandante; e (iii) seja improvável a formação de uma "menor coalizão vencedora". Das 11 arbitragens do Artigo 22.6 do ESC, essa situação somente se fez presente no caso EUA - Jogos e Apostas, o que revela a excepcionalidade da medida proposta. 
Nos casos de aplicação obrigatória da retaliação coletiva, a teoria de formação de alianças permite ainda concluir que, em tais situações, o OSC deveria ser autorizado a examinar a composição da "menor coalizão vencedora", a qual, segundo a teoria desenvolvida por Snyder, deverá contar com Membros que detenham "ativos específicos" (ou seja, fluxos comerciais de determinados produtos ou serviços de relevância para o Membro demandado) que aumentem o poder indutor da contramedida.

Ainda, a teoria de formação de alianças mostra-se útil não somente para testar a possibilidade de implantação de um mecanismo de retaliação coletiva, mas também para servir de ferramental a ser futuramente - ou seja, pós-implantação do mecanismo de retaliação coletiva - utilizado pelo próprio OSC para verificar o tipo de situação sob análise, ou seja, se passível de aplicação facultativa ou obrigatória.

Por fim, há que se ressaltar que as conclusões obtidas neste trabalho não requereram a aplicação de todo o arcabouço metodológico proposto por Glenn H. Snyder, sendo que a parte de sua teoria referente a "interação" não chegou a ser aqui testada, seja porque se revelou desnecessária, seja porque o propósito deste trabalho não compreendia sua plena aplicação, consistindo em uma primeira aproximação de tal teoria ao SSC/OMC. Não obstante, dependendo da complexidade das situações a serem examinadas, trabalhos subsequentes poderão se valer da teoria da formação de alianças, como desenvolvida por Snyder, em toda sua extensão. 


\section{E. Teoria da Paisagem de Agregação e sua Aplicação ao SSC/OMC}

\section{Introdução}

Esta seção aplica a Teoria da Paisagem de Agregação a situações em que tenha sido autorizada a tomada de contramedidas no âmbito do SSC/OMC. Tal aplicação servirá de teste adicional à possibilidade de formação de alianças (agregação) no âmbito do $\mathrm{SSC} / \mathrm{OMC}$, consistindo esta oportunidade numa primeira aproximação dessa teoria à formação de alianças no contexto da OMC.

Desenvolvida a partir de modelo de Robert Axelrod e D. Scott Bennett (1993), a Teoria da Paisagem de Agregação é um instrumento que permite apurar os lados que determinados agentes escolherão (choosing sides) em uma determinada situação de conflito. A Teoria da Paisagem foi apresentada por Robert Axelrod em texto (Choosing Sides - A Landscape Theory of Aggregation) inserido em uma obra de coletânea de tal autor (The Complexity of Cooperation), que dá seguimento a estudos anteriores seus a respeito da teoria da cooperação, sobre a qual tal autor se deteve nos anos de 1980 (The Evolution of Cooperation), em estudos que procuraram demonstrar as condições necessárias para desenvolvimento de cooperação, a qual vem sendo amplamente aplicada sobre as relações internacionais.

Axelrod expõe que dita teoria vem sendo utilizada para entender problemas de agregação em diferentes contextos, como alianças comerciais para definir padrões industriais; coalizões de partidos políticos em parlamentos; redes sociais; grupos sociais em democracias; e estruturas organizacionais.

Além disso, Axelrod discorre sobre a possibilidade de utilização de tal teoria para entender alinhamentos internacionais (em especial para prever a formação de alianças, por exemplo, em guerras). Ao assim fazer, Axelrod faz expressa referência aos trabalhos de Walt (1987), Snyder (1984) e Liska (1962), além de mencionar Morgenthau (1956) e Waltz (1979) (vale notar que Snyder (1997) ainda não havia sido lançado, mas muitas das ideias desenvolvidas por Snyder (1997) já se encontravam abordadas em Snyder (1984)). 
Axelrod pontua brevemente alguns aspectos do desenvolvimento da teoria de formação de alianças, como a questão do equilíbrio de ameaças como propulsor de alianças, mas enfatiza o aspecto abordado por Snyder, de incorporação de interesses, comuns ou conflitantes, gerais ou específicos, como fator de estabelecimento de um padrão de alinhamento, ao lado de "poder". 556

Para Axelrod, a contribuição que a Teoria da Paisagem de Agregação oferece em relação à teoria de formação de alianças até então desenvolvida é de poder agregar elementos adicionais àquela metodologia, especialmente no tocante à possível conjugação concomitante de interesses comuns e conflitantes (interesses divergentes). Para tanto, Axelrod e Bennett (1993) introduzem o conceito de propensão (baseado em interesses divergentes) o qual, conjugado com o tamanho (poder) dos países, pode determinar resultados. Com efeito, como o próprio Axelrod pontua: "particular interests and affinities have not yet been integrated into a coherent model of alignments. Landscape theory offers a way to provide this integration by representing divergent interests in the single concept of propensity, which combines with the size (power) of states to determine outcomes". 557

Nesse ponto, retomando-se o quanto desenvolvido acima, a Teoria da Paisagem de Agregação dá um passo além à teoria de Snyder que, muito embora faça abertura para que se classifique os interesses dos países em questão de acordo com sua intensidade, não permite a identificação explícita de interesses divergentes na análise. $\mathrm{Na}$ Teoria da Paisagem da Agregação, a intensidade dos interesses (ou, a propensão), nada mais será do que a soma dos interesses pró ou contra um determinado alinhamento. A presença de elementos em maior número em relação a um certo lado, determinará a escolha do lado de quem tal país tem maior propensão a - e, portanto, vai se - aliar. Como se verá abaixo, a incorporação da propensão, por fim, permite ponderar o quanto de força (ou energia, para utilizar a expressão empregada por Axelrod) um determinado alinhamento deterá, refinando o conceito de capacidade relativa, explorado por Snyder.

\footnotetext{
$556 \quad$ Axelrod e Bennett (1993), p. 83.

Ibid., p. 82.
} 


\section{Metodologia de Aplicação}

Em sua aplicação a situações de relações internacionais, a Teoria da Paisagem parte da seleção de um número de países, para cada qual se deve determinar um tamanho, definido por diferentes fatores, como fatores demográficos, industriais, militares, comerciais, ou uma combinação desses, de forma a adequar à situação específica. Para os fins deste trabalho, pelas razões expostas no Capítulo anterior, o tamanho dos países será definido pelas capacidades da "área-tema" de comércio internacional, as quais se encontram especificadas na Tabela 11, conforme refletido no Gráfico 3.

Como exposto anteriormente, dentro da Teoria da Paisagem de Agregação, cada par de países tem uma propensão para trabalhar junto. A propensão será positiva e elevada se os países tiveram boas relações; será negativa se houver muitas fontes de potencial conflito. $^{558}$

Para os fins deste trabalho, a propensão será determinada pela identificação dos interesses "pró" e "contra" de um determinado Membro em relação a uma demanda no $\mathrm{SSC} / \mathrm{OMC}$, aos quais se atribuirá uma determinada nota (com sinais positivos e negativos, respectivamente), conforme escala de 0 a 10, indicada abaixo. A soma dos interesses "pró" e "contra" permitirá identificar com precisão de que lado determinado Membro se encontra, na medida em que a soma resulte em um valor positivo (pró-demanda) ou negativo (contra-demanda).

Nesse sentido, a determinação dos interesses "pró" e "contra" em uma determinada demanda levará à formação de uma configuração composta por dois grupos: um grupo que se alinha com o Membro demandante e o outro que se alinha com o Membro demandado. Membros que adotam neutralidade nada mais apresentam que interesses comuns e conflitantes em igual intensidade, anulando-se por conseguinte (com isso, o grau de propensão soma zero).

Axelrod indica que, usando distância e propensão, é possível apurar o grau de frustração de um determinado país de pertencer a um determinado agrupamento. 
Determinado país quererá mudar de agrupamento caso o grau de frustração naqueloutro for menor do que o atual. Para os fins deste trabalho, a frustração encontra-se incorporada nas medidas de interesses "pró" ou "contra", ao passo em que se anulem, ao serem somados.

Com efeito, a Teoria da Paisagem de Agregação se completa ao calcular a energia presente em cada um dos agrupamentos. A energia do agrupamento será a soma ponderada das frustrações de cada país pertencente àquele agrupamento, sendo que o fator de ponderação são os tamanhos de cada país. ${ }^{559}$ Para os fins deste trabalho, a energia será calculada pela ponderação (multiplicação) dos tamanhos (capacidades) pela propensão de cada Membro.

Cumpre observar que a referencia à "paisagem" no nome da teoria deriva da possibilidade de se construir uma paisagem de energia, que permite visualizar as configurações e intuitivamente vislumbrar as possibilidades de mudança, conforme explica o próprio Axelrod: "Once energy is defined, the abstraction begins to pay off. Given the energy of each configuration, it is possible to construct an energy landscape. The landscape is simply a graph that has a point for each possible configuration and a height above this point for the energy of that configuration." (vide Anexo C para a a figura proposta por Axelrod e Bennett (1993), a qual todavia nos parece desnecessária para compreender os conceitos por eles desenvolvidos).

Como se depreende, o modelo em questão não necessariamente resulta em uma situação global ótima. Como expõe Axelrod, o modelo pode não resultar em uma configuração que satisfaça a todos os países. Mesmo se diante de situação global ótima, uma determinada configuração deverá contemplar algum grau de frustração por parte de alguns países, por terem de ladear em agrupamento oposto a um país "amigo" (o que permite que países "inimigos" eventualmente, dependendo das configurações em questão, estejam lado a lado).

A Teoria da Paisagem de Agregação se mostra adequada para analisar a possibilidade de formação de coalizões entre países, por contemplar as principais complexidades das relações internacionais, em plena sintonia com a teoria de formação de 
alianças.

No contexto da $\mathrm{OMC}$, a teoria da paisagem permite analisar o problema do número crescente de participantes, apresentando uma vantagem sobre outras teorias, como a dos jogos, que, com mais frequência vem sendo utilizada para examinar relações internacionais. Como Axelrod expõe, o valor da Teoria Paisagem de Agregação se encontra na possibilidade de identificação de padrões menos ou mais satisfatórios com determinadas situações de alinhamento ("landscape theory adds to game theory: is a way of characterizing all possible configurations and the dynamics among them. In particular, the idea of descent from less satisfactory patterns to more satisfactory patterns helps one characterize the entire range of possibilities in a manner that is sometimes obscure in game: theoretic treatments of n-person settings."). ${ }^{560}$

Ao considerar as preferências dos países em eventuais alinhamentos (com base nos interesses), a Teoria da Paisagem de Agregação avança um passo à frente na construção de uma teoria de formação de alianças, pelo refinamento na análise dos interesses (propensão) e no computo das capacidades (tamanhos), já que por eles ponderados. ${ }^{561}$

Como explorado adiante, a Teoria da Paisagem de Agregação, ao final, permitiu analisar o porque de em determinadas configurações se demandar uma obrigatoriedade na aplicação de contramedidas coletivas, enquanto em outras basta um mecanismo de retaliação coletiva facultativo.

\section{Aplicação aos Contenciosos $C E$ - Bananas e EUA-Jogos e Apostas}

As possibilidades oferecidas pela Teoria da Paisagem de Agregação podem ser analisadas a partir das situações envolvidas nos contenciosos EUA - Jogos e Apostas e CE - Bananas III.

Para tanto, adotou-se a seguinte metodologia:

\footnotetext{
$560 \quad$ Como já indicava Walt: "two-person game theory tells us more about the behavior within coalitions than it does about the players' choice of partners: 'game theory does not predict who will align with whom" (Walt (1983), p. 10).

561 "The point, however, is that virtually all of the power of landscape theory is in the determination of preferences (or affinities) rather than in the justification of the strategic choice." (Ibid.)
} 
- Tamanho: a partir das medidas de capacidades constantes da Tabela 11, do Anexo A, a saber: apurou-se um valor único para os tamanhos dos países participantes de cada um dos contenciosos, mediante mera multiplicação de cada uma daquelas rubricas e ajustamento de tal valor para uma base iniciando em 1.000.000 (para facilitar a compreensão do dado);

- Propensão: decorrente da soma dos interesses "pró" ou "contra" a demanda em questão. Para tanto, partiu-se da classificação indicada na análise realizada sobre os interesses dos Membros demandantes, demandados e terceiras-partes, nos contenciosos em questão. Atribuiu-se uma métrica padrão (interesse "pró", interesse "contra"), considerando que, para os fins deste trabalho, o intuito de utilizar a Teoria da Paisagem de Agregação é de caráter introdutório e exploratório;

- Configuração: dependente da soma dos interesses "pró" e "contra" para cada Membro considerado, gerando-se dois grupos distintos (i.e., duas coalizões);

- Cálculo da energia das configurações: ponderação (multiplicação) dos tamanhos pelas propensões;

- O agrupamento com energia mais elevada tende a prevalecer na demanda, servindo como método para determinação das capacidades relativas e para determinação da "menor coalizão vencedora".

A Tabela 8 abaixo apresenta os componentes acima em relação ao contencioso $C E$ - Bananas III: 
Tabela 8 - Energia Mobilizada no Caso CE - Bananas III

\begin{tabular}{|c|c|c|c|c|}
\hline Caso CE - Bananas III & Tamanho (capacidades) & & o (interesse) & Energia \\
\hline & \multicolumn{4}{|c|}{ Pró Demanda - Contra Demanda } \\
\hline Equador & 57 & 10 & 0 & 570 \\
\hline Guatemala & 22 & 10 & 0 & 220 \\
\hline Honduras & 8 & 10 & 0 & 80 \\
\hline México & 11820 & 10 & 0 & 118200 \\
\hline EUA & 761046 & 10 & 0 & 7610460 \\
\hline Canadá & 15637 & 5 & 5 & 0 \\
\hline Colômbia & 478 & 8 & 2 & 2868 \\
\hline Costa Rica & 20 & 8 & 2 & 120 \\
\hline República Dominicana & 29 & 8 & 2 & 174 \\
\hline Gana & 10 & 8 & 2 & 60 \\
\hline Japão & 90957 & 5 & 5 & 0 \\
\hline Nicarágua & 1 & 8 & 2 & 6 \\
\hline Filipinas & 519 & 6 & 4 & 1038 \\
\hline Venezuela & 126 & 8 & 2 & 756 \\
\hline Brasil & 11694 & 8 & 2 & 70164 \\
\hline Panamá & 10 & 8 & 2 & 60 \\
\hline India & 34843 & 8 & 2 & 209058 \\
\hline CE & 1000000 & 2 & 8 & -6000000 \\
\hline Belize & - & 0 & 10 & 0 \\
\hline Camarões & 7 & 0 & 10 & -70 \\
\hline Granada & - & 0 & 10 & 0 \\
\hline Jamaica & 4 & 0 & 10 & -40 \\
\hline Santa Lucia & - & 0 & 10 & 0 \\
\hline São Vicente Granadinas & - & 0 & 10 & 0 \\
\hline Senegal & 3 & 0 & 10 & -30 \\
\hline Suriname & - & 0 & 10 & 0 \\
\hline Dominica & - & 0 & 10 & 0 \\
\hline Costa do Marfim & 9 & 0 & 10 & -90 \\
\hline Madagascar & 2 & 4 & 6 & -4 \\
\hline Subtotal Pró-Demanda & & & & 8013834 \\
\hline Subtotal Contra-Demanda & & & & -6000234 \\
\hline Resultado & & & & Pró-Demanda Ganha \\
\hline
\end{tabular}

Para o caso acima, adotaram-se alguns critérios para o cálculo de propensão:

- Demandantes em contencioso análogo $(10,0)$ : requerimento de instauração de painel análogo, ou seja, contra a mesma medida, revela que os interesses são comuns, intensos e específicos (conforme classificação adotada na seção anterior), justificando indicar se tratar de intensidade máxima em favor da demanda (daí a atribuição de nota máxima em tal ponto);

- Terceiras-partes com interesse comercial:

○ Pró-demanda $(8,2)$ : atribuiu-se notas de interesse "pró" menores e de interesse "contra" maiores em relação à situação de demandantes em contencioso análogo pelo fato de o interesse comercial não ter sido capaz de conduzir o Membro a requerer a instauração de um painel autônomo a dar ensejo a um contencioso análogo, revelando haver algum inconveniente a respeito; 
○ Contra-demanda $(10,0)$ : o interesse dos Membros terceiras-partes com interesse comercial era completamente alinhado com o interesse das CE em defender sua medida (regime de importação e distribuição de bananas na União Europeia), pois eram beneficiários do regime preferencial para países-ACP e, portanto, tinham amplo interesse para defender tal regime;

- Terceira parte com mera reserva de direito/sem justificativa $(5,5)$ : atribuiu-se uma nota de empate entre interesses "pró" e "contra" (caso do Canadá);

- Demandado $(8,2)$ : atribui-se notas que levam a uma propensão menor do que os Membros demandantes, pelos óbvios ônus suportados por quem se defende em um contencioso dessa natureza.

O modelo permite verificar as energias de cada aliança. A aliança Pró-Demanda apresenta uma energia de 8,013 milhões, ao passo que a aliança Contra-Demanda, uma energia de -6 milhões. Ressalta-se que a energia da aliança Pró-Demanda já inclui as energias de Brasil e Índia, que reforçariam, portanto, a aliança Pró-Demanda, caso lhes fosse permitido participar da retaliação coletiva. Nota-se uma certa equivalência de forças (relativizada por uma propensão menor da própria CE em se defender no contencioso), confirmando a percepção anteriormente indicada de se tratar de uma disputa de difícil solução, em termos de poder, pelo relativo equilíbrio existente (há dois Membros "fortes" de cada lado).

No tocante ao contencioso EUA - Jogos e Apostas, a situação, como se sabe, é mais simples, em termos de configuração. Atribuiu-se nota máxima ao interesse "pró" de Antígua e Barbuda, sem qualquer interesse "contra", como usualmente se adota no caso de Membro demandante $(10,0)$. Da parte dos EUA, tal como CE no caso CE - Bananas III, atribuíram-se notas menores no interesse "contra" demanda, pelos ônus inerentes à defesa $(8,2)$. Como nenhuma das terceiras partes indicou a direção de seus interesses na disputa, conforme anteriormente registrado, atribuíram-se notas iguais aos interesses "PróDemanda" e "Contra-Demanda", com o que se anula a energia de cada um desses Membros. 
Tabela 9 - Energia Mobilizada no Caso EUA - Jogos e Apostas (com Retaliação

Coletiva Facultativa)

\begin{tabular}{|c|c|c|c|c|c|}
\hline \multirow[t]{2}{*}{ Caso EUA - Jogos e Apostas } & Tamanho (capacidades) & $\mathrm{x} \quad \mathrm{Pr}_{1}$ & Propensão (interesse) & $=$ & Energia \\
\hline & \multicolumn{5}{|c|}{ Pró Demanda - Contra Demanda } \\
\hline Antigua e Barbuda & - & 10 & 0 & & 0 \\
\hline China & 377772 & 5 & 5 & & 0 \\
\hline México & 11820 & 5 & 5 & & 0 \\
\hline EUA & 761046 & 2 & 8 & & -4566276 \\
\hline Canadá & 15637 & 5 & 5 & & 0 \\
\hline Japão & 90957 & 5 & 5 & & 0 \\
\hline $\mathrm{CE}$ & 1000000 & 5 & 5 & & 0 \\
\hline Subtotal Pró-Demanda & & & & & 0 \\
\hline Subtotal Contra-Demanda & & & & & -4566276 \\
\hline Resultado & & & & & Demanda Ganha \\
\hline
\end{tabular}

O resultado obtido é revelador, embora intuitivamente previsível: existe um desequilíbrio imenso entre Antígua e Barbuda, de um lado, e os EUA, do outro lado, ilustrando a impossibilidade de Antígua e Barbuda obterem o compliance dos EUA por capacidade própria, ou seja, por meio de retaliação bilateral.

Mesmo que um mecanismo de retaliação coletiva fosse permitido, verifica-se que nenhum dos demais Membros figurantes da configuração teria propensão para se aliar a qualquer um dos lados. Os demais Membros (China, México, Canadá, Japão e CE) têm notas de propensão (interesse) que se anulam, impedindo qualquer alinhamento (as energias encontram-se zeradas).

Nesse ponto entra a questão da obrigatoriedade de um mecanismo de retaliação coletiva. O intuito de um mecanismo de retaliação coletiva obrigatório teria por objetivo assegurar a formação de uma "menor coalizão vencedora" que permitisse induzir o Membro demandado ao cumprimento das recomendações do OSC. Para se obter o engajamento de Membros com capacidades (tamanhos) que permitissem a formação de uma tal coalizão, seria necessário que tais Membros apresentassem propensão para participar da coalizão.

Aqui, a obrigatoriedade de participar, na realidade, equivale a se assumir que o Membro voluntariamente, por ficção, apresenta propensão para participar da coalizão, com o que se permite calcular alguma energia de sua parte. Em verdade, a obrigatoriedade na participação da coalizão equivale a uma voluntariedade ficta para aplicar a retaliação da parte do Membro obrigado a tanto pelo OSC, com o que se eliminam todos e quaisquer 
incentivos "contra" a demanda objeto do contencioso em questão. É, assim, dizer que tratase de situação em que a maximização da energia de um determinado grupo de Membros depende da neutralização dos incentivos contrários à sua aplicação.

O quadro abaixo apresenta o cálculo das energias das alianças "Pró-Demanda" e "Contra-Demanda", em um cenário em que haja obrigatoriedade de que determinados Membros, cujas capacidades relativas, ponderadas por uma propensão máxima positiva (integralmente alinhado com o Membro demandante), as utilizem de modo a formar uma "menor coalizão vencedora":

Tabela 10 - Energia Mobilizada no Caso EUA - Jogos e Apostas (com Retaliação Coletiva Obrigatória)

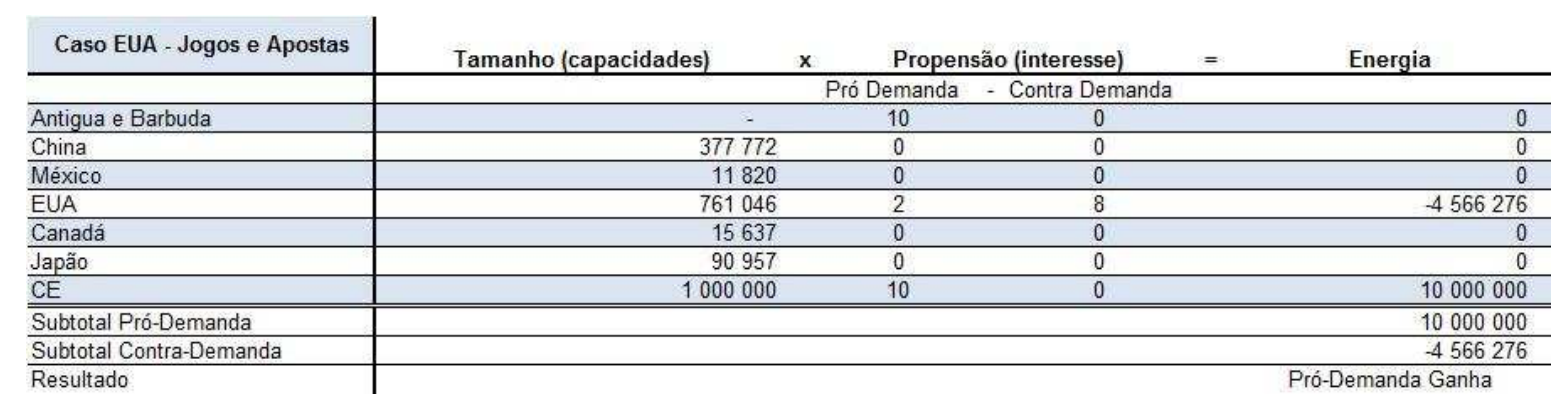

Em outras palavras, somente por um mandamento legal (ou por ficção jurídica) é que se poderia chegar a uma situação, no caso EUA - Jogos e Apostas, em que outros Membros capazes de induzir os EUA ao cumprimento das recomendações do OSC viriam a participar dos custos de uma sanção coletiva. Em nosso entender, essa conclusão justifica a introdução, no âmbito do $\mathrm{SSC} / \mathrm{OMC}$, de um mecanismo de retaliação coletiva, a ser implementado em caráter facultativo ou obrigatório, dependendo das circunstâncias, corroborando as razões para tanto expostas na última seção.

Em conclusão, a utilização da Teoria da Paisagem de Agregação se revela uma contribuição importante, como passo adicional, à teoria de formação de alianças, mostrando-se especialmente adequada para incorporar na análise de eventuais alinhamentos, ferramentas para se analisar, concomitantemente, a influência de interesses comuns ou conflitantes no processo de formação de alianças. Mais do que isso, essa primeira aproximação da Teoria da Paisagem de Agregação com o SSC/OMC parece indicar sua utilidade para possíveis análises futuras de alinhamentos, não se excluindo sua 
aplicabilidade no tocante à formação de alianças em outros contextos como, por exemplo, alinhamentos no âmbito das rodadas de negociação. 


\section{PROPOSTA NORMATIVA PARA INCORPORAÇÃO DE UM MECANISMO DE RETALIAÇÃO COLETIVA NO SSC/OMC}

Este Capítulo tem por objeto apresentar uma proposta normativa para introdução de um mecanismo de retaliação coletiva no âmbito do SSC/OMC, a ser efetivada mediante emenda ao ESC, com as devidas justificativas para tanto.

Na Seção 'E' do Capítulo VI acima, concluiu-se que um mecanismo de retaliação coletiva deve ser implementado somente em situações envolvendo desequilíbrio de poder, podendo ser de caráter facultativo ou obrigatório, conforme as condições presentes na situação fática em questão, ou seja, conforme se identifique a existência, ou não, de condições pré-conflito a propulsionar ou impedir a formação de uma "menor coalizão vencedora", em conjunto com o Membro demandante.

Como exposto anteriormente (vide Capítulo II.B acima), o Artigo 22.1 autoriza o Membro demandante, caso vencedor, a aplicar "suspensão de concessões ou outras obrigações" (contramedidas ou retaliação) contra o Membro demandado que, condenado, não cumpra após a passagem do PRT as recomendações e decisões contidas no relatório adotado pelo OSC. A adoção de contramedidas deve ser precedida de negociações entre o Membro condenado e as outras partes, de forma a buscar uma compensação mutuamente aceitável - a qual deve ser compatível com os acordos (ibid.). Nenhuma dessas duas opções, contudo, é preferível à total implementação das recomendações e decisões do relatório aprovado pelo OSC (ibid.).

Caso dentro de 20 dias da expiração do PRT não tenha havido acordo sobre uma compensação satisfatória, os Membros que houverem recorrido ao OSC (“(...) any party having invoked the dispute settlement procedures (...)") contra o condenado podem solicitar ao OSC autorização para retaliar a parte condenada (Artigo 22.2).

Como é cediço, a retaliação deve obedecer a dois critérios diferentes, um quantitativo e outro qualitativo. Quantitativamente, seu "grau (...) deve ser equivalente ao grau de anulação ou prejuízo" (Artigo 22.4). Qualitativamente, a parte que aplica retaliações deve procurar suspender em primeiro lugar concessões no mesmo acordo violado (Artigo 22.3(a)); caso considere essa suspensão de concessões como sendo "não 
praticável nem eficaz", a parte deverá ainda procurar suspender concessões ou outras obrigações em "outros setores abarcados pelo mesmo acordo" (Artigo 22.3(b)); apenas no caso de essa possibilidade também ser impraticável ou ineficaz, e se a parte considerar que “as circunstâncias são suficientemente graves", podem ser suspensas concessões ou outras obrigações em acordo diferente do violado (a chamada retaliação cruzada, prevista no Artigo 22.3(c)). Segue transcrição das partes relevantes do Artigo 22.3 do ESC, para referência:

" 3 . In considering what concessions or other obligations to suspend, the complaining party shall apply the following principles and procedures:

(a) the general principle is that the complaining party should first seek to suspend concessions or other obligations with respect to the same sector(s) as that in which the panel or Appellate Body has found a violation or other nullification or impairment;

(b) if that party considers that it is not practicable or effective to suspend concessions or other obligations with respect to the same sector(s), it may seek to suspend concessions or other obligations in other sectors under the same agreement;

(c) if that party considers that it is not practicable or effective to suspend concessions or other obligations with respect to other sectors under the same agreement, and that the circumstances are serious enough, it may seek to suspend concessions or other obligations under another covered agreement;

(d) in applying the above principles, that party shall take into account:

(i) the trade in the sector or under the agreement under which the panel or Appellate Body has found a violation or other nullification or impairment, and the importance of such trade to that party;

(ii) the broader economic elements related to the nullification or impairment and the broader economic consequences of the suspension of concessions or other obligations;

(e) if that party decides to request authorization to suspend concessions or other obligations pursuant to subparagraphs (b) or (c), it shall state the reasons therefor in its request. At the same time as the request is forwarded to the DSB, it also shall be forwarded to the relevant Councils and also, in the case of a request pursuant to subparagraph (b), the relevant sectoral bodies;" 
Conforme se pode observar, a medida de retaliação mais extrema é a retaliação cruzada - isto é, operada num acordo diferente do acordo violado -, a qual somente é aplicável se observados alguns requisitos e após seguido determinado procedimento. A excepcionalidade da medida decorre justamente da gravidade das circunstâncias justificando sua aplicação, conforme o próprio texto do ESC requer ("if that party considers that (...) the circumstances are serious enough").

Da mesma forma que a aplicação de retaliação cruzada, a aplicação da retaliação coletiva deve ser resguardada pela excepcionalidade: somente em algumas poucas circunstâncias deverá o ESC permitir ou obrigar sua aplicação, depois de ultrapassadas todas as possibilidades de indução ao cumprimento atualmente previstas. Com efeito, por ser uma medida mais extrema do que a retaliação cruzada (por envolver Membros que não figuraram como demandantes no contencioso original), a retaliação coletiva deverá ter lugar, preferencialmente, após o Membro demandante ter buscado aplicar contramedidas bilaterais no mesmo setor e também no mesmo acordo em que se tenha encontrado uma violação (Artigo 22.3(a)); e, preferencialmente, após o Membro demandante ter obtido autorização para aplicar retaliação cruzada, para o que terá considerado que a aplicação da retaliação originária era "não praticável nem eficaz".

A retaliação coletiva tem um marco distintivo em relação às demais formas de retaliação: o desequilíbrio de poder. Como a retaliação coletiva tem por fundamento o desequilíbrio de poder, deverá ser reservada a situações em que a retaliação bilateral (mesmo que sob a forma "cruzada") seja "insuficiente" ou "ineficaz" para induzir o Membro demandado a atender as recomendações do OSC ("não for suficiente nem eficaz").

Com base em tais conceitos de insuficiência e ineficácia, o Membro poderá requerer ao OSC permissão para que outros países se voluntariem a participar do procedimento de retaliação coletiva. Embora preferencialmente se deva aguardar o resultado da aplicação da retaliação bilateral, para se evitar atrasos indevidos na aplicação das contramedidas, poderá ser admitida imediatamente a aprovação para aplicação de retaliação coletiva caso haja elementos demonstrando convincentemente que a aplicação de retaliação bilateral será insuficiente e ineficaz para induzir o cumprimento. 
O OSC emitirá a autorização requerida, não tomando qualquer medida além de dar a autorização, cabendo aos Membros se organizarem autonomamente no tocante à estruturação da retaliação. A emenda deverá conferir plena autonomia para o Membro demandante se organizar com os demais Membros interessados na retaliação (respeitado o princípio da proporcionalidade da sanção - Artigo 22.4 do ESC), em consonância com a regra de que é o Membro retaliante quem determina a forma de aplicação da retaliação (nesse sentido, não cabe ao árbitro da arbitragem do Artigo 22.6 "examinar a natureza" das contramedidas, conforme estatui o Artigo 22.7).

Decorrido determinado período de tempo, caso nenhum Membro se apresente para participar da retaliação coletiva - ou caso os que tenham se voluntariado não reúnam capacidades suficientes para formar uma "menor coalizão vencedora" - o OSC poderá ser instado pelo Membro demandante a sugerir que determinados Membros participem da retaliação coletiva, por poderem vir a formar uma aliança suficiente para induzir o Membro demandado ao cumprimento (a metodologia de análise utilizada nesta tese poderá ser de grande valia ao OSC ao realizar tal sugestão). Por se tratar de mera sugestão, não deterá caráter obrigatório, mas consistirá em mais um passo no processo dissuasório do Membro demandado.

Passado determinado período de tempo sem que tenha sido formada uma "menor coalizão vencedora", a pedido do Membro demandante, o OSC poderá exercer a prerrogativa de determinar a certos Membros que obrigatoriamente participem da retaliação coletiva, podendo o OSC indicar também os fluxos comerciais a serem objeto da retaliação.

Cumpre esclarecer que, da mesma forma que no procedimento tendente à aplicação de retaliação cruzada, embora tenha o Membro demandante a prerrogativa de considerar que a retaliação bilateral não seja suficiente para induzir ao cumprimento (no caso da retaliação, tem a prerrogativa de considerar que a retaliação no mesmo setor ou no mesmo acordo "não praticável nem eficaz", consoante Artigo 22.3(c)), deverá o Membro apresentar ao OSC as razões pelas quais entenda seja insuficiente a retaliação bilateral (quanto à retaliação coletiva, o Membro demandante "shall state the reasons thereof in its request", conforme Artigo 22.3(c) do ESC). 
Nesse sentido, a insuficiência ou a ineficácia da retaliação bilateral poderá ser demonstrada pela existência de uma situação de desigualdade entre as capacidades relativas do Membro demandante e do demandado (como era o caso entre EUA e Antígua e Barbuda), bem como poderão ser inferidas caso decorra tempo mais que razoável após a aplicação de contramedidas bilaterais, sem que o Membro demandado adote as recomendações do OSC.

De toda forma, bastará ao texto legal indicar a necessidade de demonstração do padrão de "insuficiência" ou "ineficácia", sem adentrar os requisitos de sua caracterização, deixando ao desenvolvimento "jurisprudencial" a definição dos contornos de tais conceitos, da mesma forma como ocorreu com o desenvolvimento do conceito de retaliação "não praticável nem eficaz", exigido para autorização de contramedidas cruzadas. Não obstante, os aspectos abordados no parágrafo anterior poderão ser mencionados genericamente no texto do ESC, como guia interpretativo, servindo o mesmo propósito dos dispositivos contidos no Artigo 22.3(d)(i) e (ii).

Posto isso, apresenta-se abaixo proposta de emenda do Artigo 22 do ESC, mediante a incorporação das alíneas " $h$ " e “i” no parágrafo 3 do Artigo 22, para se prever a possibilidade de o Membro demandante requerer a aplicação de retaliação coletiva no âmbito do SSC/OMC (redação proposta inserida a partir do item " $h$ ", destacada em negrito e itálico):

"3. In considering what concessions or other obligations to suspend, the complaining party shall apply the following principles and procedures:

$(\ldots)$

(h) if that party considers that the suspension of concessions or other obligations by that party is not sufficient or effective, and that the circumstances are serious enough because of an imbalance of power between that party and the Member concerned, it may request the DSB to authorize other Members not participating in the complaint to suspend concessions or other obligations in conjunction with that party;

(i) if that party decides to request authorization for other Members to suspend concessions or other obligations in conjunction with that 
party, pursuant to subparagraph (h), it shall state the reasons therefor in its request." (texto adicionado em destaque)

Buscando preservar a estrutura original do Artigo 22 do ESC, propõe-se, também, a adição de trecho no parágrafo 6 do Artigo 22, conforme redação abaixo, mediante o qual se prevê o processo de aprovação de um requerimento de retaliação coletiva pelo OSC, permitindo que tal requerimento seja levado à análise da arbitragem do próprio Artigo 22.6:

"6. When the situation described in paragraph 2 occurs, the DSB, upon request, shall grant authorization to suspend concessions or other obligations within 30 days of the expiry of the reasonable period of time unless the DSB decides by consensus to reject the request. However, if the Member concerned objects to the level of suspension proposed, or claims that the principles and procedures set forth in paragraph 3 have not been followed where a complaining party has requested authorization to suspend concessions or other obligations pursuant to paragraph 3(b), (c) or (h), the matter shall be referred to arbitration. Such arbitration shall be carried out by the original panel, if members are available, or by an arbitrator (15) appointed by the Director-General and shall be completed within 60 days after the date of expiry of the reasonable period of time. Concessions or other obligations shall not be suspended during the course of the arbitration.

The DSB, upon request, may suggest or recommend that certain Members suspend concessions or other obligations in conjunction with the complaining party, if no Member voluntarily suspends concessions or other obligations in conjunction with the complaining party, despite authorization had been given for a request made pursuant to paragraph $3(\mathrm{~h})$. In such cases, the complaining party may request assistance of the $D S B$ in defining the nature of the concessions or other obligations to be suspended to ensure their sufficiency and effectiveness." (texto adicionado em destaque)

É importante registrar que, da forma como proposta, a adição do mencionado trecho no parágrafo 6 do Artigo 22 do ESC não requererá modificação no texto do parágrafo 7 do mesmo artigo, pois o parágrafo 7 permite ao árbitro, com base no mesmo dispositivo, determinar se as regras e princípios do parágrafo 3 foram observados, o que compreenderá, na redação proposta, análise dos requisitos contidos no subparágrafo " $h$ " (isto é, insuficiência ou ineficácia da retaliação bilateral e verificação de um desequilíbrio de poder entre o Membro demandante e o demandado). 


\section{CONCLUSÃO}

Esta tese teve por objeto analisar a viabilidade de implementação, no âmbito do sistema de solução de controvérsias da OMC, de um mecanismo de contramedidas (retaliação) coletiva, à luz da teoria de formação de alianças, tal qual desenvolvida na teoria de relações internacionais, sobretudo da forma como sistematizada por Glenn H. Snyder.

Ao assim fazer, buscou-se averiguar se e em quais condições um mecanismo tal seria necessário e viável no SSC/OMC, para então propor uma forma de implementação de um mecanismo de retaliação coletiva no sistema. A nosso ver, a aplicação de tal teoria ao $\mathrm{SSC} / \mathrm{OMC}$ revelou algumas relevantes contribuições.

A primeira importante contribuição de tal aproximação foi constatar a adequação de tal teoria para compreender o dilema do compliance no SSC/OMC. Como anteriormente exposto, o enforcement do SSC/OMC ainda se funda em soluções de self-help, ou seja, dependente da força, do poder, do Membro demandante em induzir o Membro demandado a cumprir as recomendações do OSC, mediante a aplicação de retaliação bilateral, historicamente centrada na reciprocidade.

Consistindo o problema do enforcement do SSC/OMC em uma questão de poder, pode-se logo apontar outra contribuição da teoria: a possibilidade de entender o problema do desequilíbrio de poder, tão caro dentro do contexto da OMC e apontado como um dos problemas de legitimidade da instituição. A análise das relações de força, ou de poder, está exatamente na origem da teoria de formação de alianças, na medida em que, nos dizeres de Morgenthau, "somente o poder pode aplacar o poder".

A teoria de formação de alianças também se mostrou adequada como modelo metodológico para a análise empreendida, diante da configuração do sistema de comércio internacional como uma anarquia, dentro de um estrutura de multipolaridade, em que por conseguinte não é possível perceber ex ante os possíveis alinhamentos, diante de uma determinada configuração. 
Tomando isso como premissa, com base no arcabouço teórico apresentado, foi possível confirmar a necessidade de adoção de um mecanismo de retaliação coletiva no SSC/OMC, como alternativa para lidar com o problema do desequilíbrio de poder. Nessa linha, em mais uma contribuição, a teoria deu elementos para se identificar quando a retaliação coletiva deverá ser desnecessária, facultativa ou obrigatória, para o que se valeu de conceitos como, dentre outros, "capacidade relativa", "menor coalizão vencedora", "aliança-dependência", além da necessária análise da situação pré-aliança dos interesses das unidades envolvidas, como propulsionadora ou limitadora da formação de alianças.

Ainda quanto a interesses, a tese se beneficiou da apresentação de uma teoria até então pouco explorada (Teoria da Paisagem de Agregação), que, em continuidade à teoria de formação de alianças, permitiu incorporar na análise de eventuais alinhamentos, ferramentas para se examinar, concomitantemente, a influência de interesses comuns ou conflitantes no processo de formação de alianças. Mais do que isso, revelou que a obrigação de se impor retaliação equivale, para o Membro obrigado a tanto, a uma situação de plena voluntariedade para aplicação da retaliação coletiva (assumida por ficção júridica), em que a maximização das capacidades de um determinado grupo de Membros depende da neutralização dos incentivos contrários à sua aplicação - e, portanto, somente é atingível com tal obrigatoriedade.

Enfim, com base nesses apontamentos, propôs-se texto de emenda aos Artigos 22.3 e 22.6 do $E S C$, por meio da qual se poderá incorporar um mecanismo de retaliação coletiva no SSC/OMC, mediante a observância de determinados critérios legais, como (i) a demonstração da ocorrência de uma situação de desequilíbrio de poder entre Membro demandante e Membro demandado e (ii) a comprovação de que a retaliação bilateral seria "não suficiente nem eficaz" (requisitos da "insuficiência" e "ineficácia" da retaliação bilateral).

A adoção de um mecanismo de retaliação coletiva, como anteriormente exposto, parte do pressuposto de que os Membros da OMC prezam pelo fiel cumprimento das obrigações estampadas no Acordo da OMC. Sua adoção poderá servir, portanto, como uma norma de fechamento de sistema, por reformar o último instituto do SSC/OMC (o enforcement) que ainda se funda na estrutura desenhada nas Conferências de Bretton Woods, ou seja, na velha reciprocidade bilateral. 
A adoção de um mecanismo de retaliação coletiva, até porque revestido de excepcionalidade, conforme proposto acima, não deverá ser vista como uma panaceia. Antes disso, é desejável que o mecanismo de retaliação coletiva nunca venha a ser utilizado. Idealmente, tal mecanismo deverá servir tão-somente como um sinal claro da plena eficácia do SSC/OMC, a levar todos os Membros da OMC a agir e negociar sob a sombra de uma ameaça crível, de forma a atingir soluções mutuamente satisfatórias às controvérsias processadas perante o SSC/OMC.

A expectativa de implementação de um mecanismo de retaliação coletiva no SSC/OMC não é imediata. Pode-se levar anos até que angarie suporte necessário para sua adoção pelos Membros da OMC. A falta de apoio político todavia não deve refrear o papel da Academia, que se sobreleva na propositura de possíveis soluções aos dilemas dos sistemas que se dispõe a examinar. Embora as preferências políticas dos Membros sejam difíceis de prever, cabe à Academia apresentar os possíveis aprimoramentos que o sistema poderia incorporar, dentre os quais certamente deverá estar a adoção de um mecanismo de retaliação coletiva, mecanismo esse há décadas defendido pelos Membros fracos e médios da OMC, dentre os quais o próprio Brasil. A tal fim esta tese procurou atender. 


\section{BIBLIOGRAFIA}

\section{A. LIVROS}

ALDENDERFER, Mark S.; BLASHFIELD, Roger K. (1984). Cluster Analysis. Beverly Hills: Sage, 88 p.

ALLAND, Denis (1994). Justice privée et ordre juridique international . Étude théorique des contre-mesures en droit international public. Paris: Pedone, 503 p.

ALVAREZ, José E. (2006). International Organizations as Law-makers. New York: Oxford University Press, 720 p.

AMARAL JÚNIOR, Alberto do (2008). A Solução de Controvérsias na OMC. São Paulo: Editora Atlas, $234 \mathrm{p}$.

AMARAL JÚNIOR, Alberto do (2008). Introdução ao Direito International Público. São Paulo: Editora Atlas S.A., 546 p.

ARAUJO BRAZ, Mario S. (2006) Retaliação na OMC. Biblioteca de Direito Internacional. Curitiba: Juruá, pp. 604.

AUSTIN, John (1995, first published 1832). The Province of Jurisprudence Determined. Wilfrid RUMBLE (ed.). Cambridge: Cambridge University Press, 344 p.

AXELROD, Robert (1984). The Evolution of Cooperation. New York: Basic Books, 241

p.

AXELROD, Robert (1997). The Complexity of Cooperation: Agent-Based Models of Competition and Collaboration. Princeton Studies in Complexity. Princeton: Princeton University Press, 248 p.

BAYARD, Thomas O. / Kimberly A; ELLIOTT et al. (1994). Reciprocity and Retaliation in U.S. Trade Policy. Washington, D.C.: Institute for International Economics, xiv-503 p. BHAGWATI, Jagdish N. / Hugh T. PATRICK (1990). Aggressive Unilateralism: America's 301 Trade Policy and the World Trade System. Ann Arbor: The University of Michigan Press, xii-265 p.

BHAGWATI, Jagdish N. (2002). Free Trade Today. Princeton: Princeton University Press, $121 \mathrm{p}$.

BHALA, Raj (2001). International Trade Law: Theory and Practice. New York: Lexis Pub, 1xx-1762 p.

BHALA, Raj / Kevin KENNEDY (1998). World Trade Law: The GATT-WTO System, Regional Arrangements, and U.S. Law. Charlottesville: LEXIS Law Publishing, xl-1382 p. 
BUCKER, Fátima C. B. (2007). Aspectos Contemporâneos do Direito Internacional. Tese de Doutorado defendida na Universidade de São Paulo. São Paulo.

BULL, Hedley (1977). The Anarchical Society: A Study of Order in World Politics. New York: Columbia University Press, 368 p.

CALLIARI, Marcelo (2003). A aplicabilidade da teoria dos jogos ao direito internacional : um estudo exploratório. FADUSP, Tese de Doutorado.

CARLSNAES, Walter et al. (2002). Handbook of International Relations. London: Sage, $571 \mathrm{p}$.

CHAYES, Abram / Thomas EHRLICH et al.(1968). International Legal Process; Materials for an Introductory Course. Boston: Little Brown, 1402 p.

CHAYES, Abram / Antonia H. CHAYES (1995). The New Sovereignty: Compliance with International Regulatory Agreements. Cambridge, MA: Harvard University Press, 432 p.

CHOWDHURY, Debashish (1986). Spin Glasses and Other Frustrated Systems. Princeton: Princeton University Press, xiii-385p.

COLEMAN, James A. (1990). Foundations of Social Theory. Cambridge, MA: The Belknap Press of Harvard University Press, xvi-993 p.

DESTLER, I. M. (1992). American trade politics. Washington, DC; New York, NY: NYU Press, $453 \mathrm{p}$.

DREZNER, Daniel W. (2007). All Politics is Global: Explaining International Regulatory Regimes. Princeton : Princeton University Press, 234 p.

EGGERTSSON, Thrainn (1990). Economic Behavior and Institutions. Cambridge [etc.]: Cambridge University Press, xv-385 p.

FISHER, Roger (1981). Improving Compliance with International Law. Charlottesville, VA : University of Virginia Press, 370 p.

FRANCK, Thomas M. (1995). Fairness in International Law and Institutions. Oxford, New York: Clarendon Press; Oxford University Press, 415 p.

FRIEDMAN, Julian R. / Christopher BLADEN / Steven ROSEN (1970). Alliance in International Politics. Boston: Allyn and Bacon.

HARDIN, Russell (1982). Collective Action. Baltimore, MD: The Johns. Hopkins University Press for Resources for the Future, xvi-248 p.

HART, H. L. A. (1994). The Concept of Law. Oxford: Clarendon Press, 328 p.

HENKIN, Louis (1979). How Nations Behave : Law and Foreign Policy. New York, Published for the Council on Foreign Relations by Columbia University Press, 322 p. 
HOVI, Jon (1998). Games, Threats \& Treaties - Understanding Commitments in International Relations. London, Pinter, 160 p.

HUDEC, Robert E. (1990). The Gatt Legal System and World Trade Diplomacy. Salem, NH: Butterworth, xxi-376 p.

HUDEC, Robert E. (1993). Enforcing International Trade Law: The Evolution of the Modern Gatt Legal System. Salem, NH: Butterworths, 630 p.

HUDEC, Robert E. (1999). Essays on the nature of international trade law. London: Cameron May, 395 p.

HUNTINGTON, Samuel P. (1996). The Clash of Civilizations and the Remaking of World Order. New York: Simon and Schuster, 367 p.

INTERNATIONAL MONETARY FUND (2010). World Economic Outlook : A Survey by the Staff of the International Monetary Fund. Washington, DC : IMF, 217 p. (dados completos em http://www.imf.org/external/pubs/ft/weo/2010/02/weodata/index.aspx, acessado em 22 de janeiro de 2011)

JACKSON, John H. (1990). Restructuring the GATT System. London: Chatham House Papers, iv-121 p.

JACKSON, John H. (1997). The World Trading System : Law and Policy of International Economic Relations. Cambridge, MA: MIT Press, 400 p.

JACKSON, John H. (1969). World Trade and the Law of GATT: A Legal Analysis of the General Agreement on Tariffs and Trade. Indianapolis: Bobbs-Merrill, 948 p.

JACKSON, John H. / William J. DAVEY (2008). Legal Problems of International Economic Relations : Cases, Materials, and Text on the National and International Regulation of Transnational Economic Relations. St. Paul, MN: West Pub. Co., 1248 p.

KAUFMAN, Leonard / Peter J. ROUSSEEUW (1990). Finding Groups in Data: An Introduction to Cluster Analysis. New York: Wiley, 368 p.

KELSEN, Hans (1952). Principles of International Law. New York: Rinehart, xvii-461 p. KELSEN, Hans (1967). Pure Theory of Law. Berkeley: University of California Press, x$356 \mathrm{p}$.

KEOHANE, Robert O. (1984). After Hegemony: Cooperation and Discord in the World Political Economy. Princeton, NJ: Princeton University Press, 290 p.

KEOHANE, Robert O. (ed) (1986). Neorealism and Its Critics. New York: Columbia University Press.

KEOHANE, Robert O. (2002). Power and Governance in a Partially Globalized World. London, Routledge. 
KENNEDY, Daniel L. M. / James D. SOUTHWICK (eds). (2002). The Political Economy of International Trade Law: essays in honour of Robert E. Hudec. Cambridge, UK; New York: Cambridge University Press, 712 p.

KRASNER, Stephan D. (ed.) (1981). International Regimes. Ithaca, Cornell University Press, $372 \mathrm{p}$.

LAFER, Celso (1998). A OMC e a Regulamentação do Comércio Internacional: Uma Visão Brasileira. Porto Alegre: Livraria do Advogado, 168 p.

LAWRENCE, Robert Z. (2003). Crimes \& Punishments? Retaliation under the WTO. Washington, DC: Institute for International Economics; 120 p.

LIMA, Tatiana M. N. (2004). GATT/OMC: uma Análise Institucional. Tese de Mestrado defendida na Universidade de São Paulo. São Paulo.

LISKA, George (1962). Nations in Alliance. Baltimore, MD: Johns Hopkins University Press, pp x-301.

LOWENFELD, Andreas F. (2002). International economic law. Oxford/New York: Oxford University Press, 824 p.

LUCK, Edward C. / Michael W. DOYLE (2004). International Law and Organization: Closing the Compliance Gap, Boulder: Rowman and Littlefield.

MAQUIAVEL, Nicolau (2010). O Príncipe. São Paulo: Penguin Companhia.

MEZARD, M.; PARISI, G.; VIRASORO, M. A. (1987). Spin Glass Theory and Beyond. Singapore: World Scientific, xiii-461 p.

MORGENTHAU, Hans J. (1956). Politics Among Nations. New York: Alfred A. Knof, $703 \mathrm{p}$.

NICOLIS, Gregoire / Ilya PRIGOGINE (1989). Exploring Complexity. New York: Freeman, $328 \mathrm{p}$.

NORTH, Douglass C. (1990). Institutions, Institutional Change and Economic Performance. Cambridge: Cambridge University Press, 159 p.

NYE JR., Joseph S. (2002) (Trad. Luiz A. Oliveira de Araújo). O paradoxo do poder americano. Por que única superpotência do mundo não pode prosseguir isolada. São Paulo: Unesp.

O'KELLEY, Charles R.T. / Robert B. THOMPSOM (1999). Corporations and Other Business Associations: Cases and Materials. Aspen: Law \& Business, 1135 p.

OLSON, Mancur (1965). The Logic of Collective Action; Public Goods and the Theory of Groups. Cambridge, MA: Harvard University Press, 186 p. 
OSTROM, Elinor (2002). Governing the Commons: The Evolution of Institutions for Collective Action. Political Economy of Institutions and Decisions. Cambridge: Cambridge University Press.

OYE, Kenneth A. (ed.) (1986). Cooperation Under Anarchy. Princeton: Princeton University Press, 269 p.

PALAN, Ronen (ed.) (2000). Global Political Economy: Contemporary Theories. London: Routledge, xvii, $286 \mathrm{p}$.

PALMETER, David / Petros C. MAVROIDIS (1999). Dispute Settlement in the World Trade Organization: Practice and Procedure. The Hague; Boston: Kluwer Law International, $325 \mathrm{p}$.

PALMETER, David (2003). The WTO as a Legal System: Essays on International Trade Law and Policy. London: Cameron May.

PAUWELYN, Joost (2003). Conflict of Norms in Public International Law: How WTO Law Relates to other Rules of International Law. Cambridge, Cambridge University Press, $560 \mathrm{p}$.

PETERSMANN, Ernst.-Ulrich (1997). International trade law and the GATT/WTO dispute settlement system. London/Boston: Kluwer Law International, 704 p.

PINES, David (ed.) (1985). Emerging Syntheses in Science: Proceedings of the Founding Workshops of the Santa Fe Institute, Santa Fe, New Mexico. Santa Fe, NM: Santa Fe Institute, $250 \mathrm{p}$.

PRESSMAN, Jeremy (2008). Warring Friends: Alliance Restrainst in International Politics. Ithaca, NY: Cornell University Press.

ROSENAU, James N. / Ernst-Otto CZEMPIEL (eds) (1992). Governance Without Government: Order and Change in World Politics, Cambridge/New York: Cambridge University Press, $311 \mathrm{p}$.

ROTHSTEIN, Robert L. (1968). Alliances and Small Powers. New York: Columbia University Press.

SHAFFER, Gregory C. (2003). Defending Interests: Public-Private Partnerships in WTO Litigation. Brookings Institution Press. Washington, D.C.

TAYLOR, Michael (1987). The Possibility of Cooperation. Cambridge: Cambridge University. Press, 205p.

TRACHTMAN, Joel P. (2008). The Economic Structure of International Law. Cambridge, MA: Harvard University Press, 354 p. 
TWIGGS, Joan E. (1987). The Tokyo Round of Multilateral Trade Negotiations: a Case Study in Building Domestic Support for Diplomacy. Washington, D.C. Lanham, MD: University Press of America, $152 \mathrm{p}$.

VIEIRA, Maria C. B. C. (2007). OMC e Países em Desenvolvimento: Análise Empírica sobre a Institucionalidade do Mecanismo de Solução de Controvérsias. Tese de Mestrado defendida na Pontifícia Universidade Católica do Rio de Janeiro. Rio de Janeiro, in http://www.maxwell.lambda.ele.puc-

rio.br/cgibin/db2www/PRG_0991.D2W/SHOW?Cont=11655:en\&Mat=\&Sys $=\& N r=\& F u n$ $=\&$ CdLinPrg=en, acessado em 09/03/2009.

WALT, Stephan M. (1987). The Origins of Alliances. Ithaca, NY: Cornell University Press, $\mathrm{x}-321 \mathrm{p}$.

WALTZ, Kenneth N. (1979). Theory of International Politics. Reading, MA: AddisonWesley, iv-251 p.

WEISS, Edith B. / Harold K. JACOBSON (eds) (1998). Engaging Countries: Strengthening Compliance with International Environmental Accords. Cambridge, MA, London: The MIT Press, $615 \mathrm{p}$.

WILCOX, Clair (1949). A Charter for World Trade. New York: The Macmillan Company, xvii-333 p.

WILLIAMSON, Oliver E. (1985). The Economic Institutions of Capitalism: Firms, Markets, Relational Contracting. New York; London: Free Press, 450 p.

WINHAM, Gilbert R. (1986). International Trade and the Tokyo Round Negotiation. Princeton, NJ: Princeton University Press, xiv-449 p.

WORLD TRADE ORGANIZATION (2007). Analytical Index: Guide To GATT Law And Practice, $2^{\text {nd }}$ Edition. Geneva: Bernan, 2500 p.

WORLD TRADE ORGANIZATION (2010). International Trade Statistics 2010. Geneva: WTO, 250 p. (dados completos em www.wto.org/statistics, acessado em 22 de janeiro de 2011)

YARBROUGH, Beth V. / Robert M. YARBROUGH (1992). Cooperation and Governance in International Trade: The Strategic Organizational Approach. Princeton, NJ: Princeton University Press, xi-182 p.

ZOLLER, Elisabeth (1984). Peacetime Unilateral Remedies: An Analysis of Countermeasures. Dobs Ferry, New York: Transnational, 224 p. 


\section{B. ARTIGOS}

ABBOTT, Kenneth W. (1992). "GATT as a Public Institution: the Uruguay Round and Beyond", Brooklyn Journal of International Law, New York, v. 18, pp. 31-86.

ABBOTT, Kenneth W. / Robert O. KEOHANE (2000). "The Concept of Legalization”, International Organizations, $\quad$ v. $\quad 54, \quad$ pp. $401-419$. ABBOTT, Kenneth W. / Duncan SNIDAL (1998). "Why States Act through Formal International Organizations”, Journal of Conflict Resolution, v. 42, n. 1, pp. 3-32.

ABBOTT, Roderick (2007). “Are Developing Countries Deterred from Using the WTO Dispute Settlement System? - Participation of Developing Countries in the DSM in the years 1995-2005”, ECIPE Working Paper, n. 1, in http://www.ecipe.org/publications/ecipe-working-papers/are-developing-countriesdeterred-from-using-the-wto-dispute-settlement-system/PDF, acessado em 22 de janeiro de 2011. (ECIPE - European Center for International Political Economy).

ACEVES, William J. (1997). "Institutionalist Theory and International Legal Scholarship", American University Journal of International Law and Policy, vol. 12, pp. 227-266. ALTFELD, Michael F. / Bruce BUENO DE MESQUITA (1979). "Choosing Sides in War", International Studies Quarterly, v. 23, pp. 87-223.

ALVAREZ, José E. (2000). “The WTO as Linkage Machine”, American Journal of International Law, v. 96, pp. 146-158.

ALVAREZ, José E. (2005). “Do States Socialize?”, Duke Law Journal, Durham, v. 54, n. 4, pp. 961-974.

AREND, Anthony C. (1998). "Do Legal Rules Matter? International Law and International Politics", Virginia Journal of International Law, Charlottesville, v. 38, pp. 107-154. ASHMAN, Kenneth J. (1989). “The Omnibus Trade and Competitiveness Act of 1988 The Section 301 Amendments: Insignificant Changes from Prior Law?”, Boston University International Law Journal, v. 7, pp. 115-153.

AXELROD, Robert / Robert O. KEOHANE (1985). “Achieving Cooperation Under Anarchy: Strategies and Institutions", World Politics, v. 38, p. 226-254.

BAGWELL, Kyle / Petros C. MAVROIDIS / Robert W. STAIGER (2004). "The Case for Tradable Remedies in WTO Dispute Settlement", World Bank Policy Research Working Paper, no. 3314, in http://econ.worldbank.org/external/default/main?pagePK=64165259\&theSitePK=469382\& 
piPK $=64165421 \&$ menuPK $=64166093 \&$ entity $I D=000112742 \_20040727165316$, acessado em 22 de janeiro de 2011.

BAGWELL, Kyle / Robert W. STAIGER (2001). "Reciprocity, Non-discrimination And The Preferential Agreements In The Multilateral Trading System", European Journal of Political Economy, v. 17, no. 2, pp. 281-325.

BAGWELL, Kyle / Petros C. MAVROIDIS / Robert W. STAIGER (2003). "The Case for Auctioning Countermeasures in the WTO”, NBER Working Papers, No. 9920.

BECKER, Gary S. (1983). "A Theory of Competition Among Pressure Groups for Political Influence", The Quarterly Journal of Economics, v. XCVIII, n. 3, pp. 371-400.

BELLO, Judith Hipler (1996). “The WTO Dispute Settlement Understanding: Less is More", American Journal of International Law, n. 90, pp. 416-418.

BHALA, Raj (1997). "Hegelian Reflections on Unilateral Action in the World Trading System", Berkeley Journal of International Law, v. 5, pp. 159-244.

BISHOP, Andrew S. (2002). "The Second Legal Revolution in International Trade Law: Ecuador Goes Ape in Banana Trade War With European Union", International Legal Perspective, v. 12, pp. 1-3.

BOURGEOIS, Jacques H. J. / Pascal LAURENT (1985). "Le 'nouvel instrument de politique commerciale': un pas en avant vers l'élimination des obstacles aux échanges internationaux", Revue Trimestrielle du droit Européen, v. 21, pp. 41-63.

BOWN, Chad P. / Bernard M. HOEKMAN (2005). "WTO Dispute Settlement and the Missing Developing Country Cases: Engaging the Private Sector", Journal of International Economic Law, v. 8, n. 4, pp. 861-890.

BOWN, Chad P. (2005). "Trade Remedies and World Trade Organization Dispute Settlement: Why Are So Few Challenged?”, The Journal of Legal Studies, Chicago, v. 34, n. 2, pp. 515-555.

BREWSTER, Rachel (2006). "Rule-Based Dispute Resolution in International Trade Law”, Virginia Law Review, Charlottesville, v. 92, n. 2, pp. 251-288.

BRONCKERS, Marco C .E. J (1984). "Private Response to Foreign Unfair Trade Practices - United States and EEC Complaint Procedures", Northwestern Journal of International Law \& Business, v. 6 pp. 651-759.

BRONCKERS, Marco / Naboth van den BROEK (2005). "Financial Compensation in the WTO - Improving the Remedies of WTO Dispute Settlement", Journal of International Economic Law, v. 8, n. 1, pp. 101-126. 
BUCHANAN, James M. (1991). "The Domain of Constitutional Political Economy", in Id., The Economics and the Ethics of Constitutional Order. Ann Arbor, University of Michigan Press, pp. 3-41.

CARMODY, Chios (2008). “A Theory of WTO Law”, Journal of International Economic Law, v. 11, n. 3, pp. 527-557.

CARMODY, Chios (2002). "Remedies and Conformity Under The WTO Agreement", Journal of International Economic Law, v. 5, n. 2, pp. 307-329.

CHARNOVITZ, Steve (2001). "Rethinking WTO Trade Sanctions", American Journal of International Law, v. 95, pp. 792-832.

CHARNOVITZ, Steve (2002). “The WTO's Problematic 'Last Resort' Against Noncompliance", Aussenwirtschaft. The Swiss Review of International Economic Relations, v. 57, pp. 409-440.

CHARNOVITZ, Steve / Jason E. KEARNS (2002). "Adjudicating Compliance in the WTO: a Review of DSU Article 21.5”, Journal of International Economic Law, v. 5, n. 2, pp. 331-352.

CHO, Sungjoon (2004). “The Nature of Remedies in International Trade Law”, University of Pittsburgh Law Review, v. 65, n. 1, pp. 763-810.

CHOINSKI, Alexander Stewart (2002). "Anatomy of a Controversy: The Balance of Political Forces Behind Implementation of the WTO's Gasoline Decision", Law and Policy in International Business, v. 33, n. 4, pp. 569-613.

CHURCHILL, Robin R. / Geir ULFSTEIN (2000). “Autonomous Institutional Arrangements in Multilateral Environmental Agreements: A Little-Noticed Phenomenon in International Law", American Journal of International Law, v. 94 p. 623-659. CLARK, Hunter R. / Amy BOGRAN / Hayley HANSON (2001). "The WTO Ruling on Foreign Sales Corporations: Costliest Battle Yet in an Escalating Trade War Between the United States and the European Union?", Minnesota Journal of Global Trade, v. 10, pp. 291-321.

COASE, Ronald H. (1937). "The Nature of the Firm”, Economica, New Series, Vol. 4, No. 16, pp. 386-405.

COASE, Ronald H. (1960). "The Problem of Social Cost", The Journal of Law and Economics, v. 3, pp. 1-44.

COLLINS, David (2009). "Efficient Breach, Reliance and Contract Remedies at the WTO”, Journal of World Trade, v. 43, p. 225-244. 
COMISSÃO DE DIREITO INTERNACIONAL (ONU), Projeto de Artigos sobre a Responsabilidade dos Estados por Fato Internacionalmente Ilícito, anexo à Resolução 56/83 da Assembléia Geral da ONU de 12 de dezembro de 2001.

DAVEY, Wiliam J. (2003). "The WTO Dispute Settlement Mechanism”, Illinois Public Law and Legal Theory Research Papers Series, Research Paper no. 03-08, in http://papers.ssrn.com/abstract=419943, acessado em 22 de janeiro de 2011.

DAVEY, William J. (2005). "The WTO Dispute Settlement System: the first Ten Years", Journal of International Economic Law, v. 8, n. 1, pp. 17-50.

DAVEY, William J. (2006). “The WTO: Looking Forwards", Journal of International Economic Law, Oxford, v. 9, n. 1, pp. 3-29.

DIEBOLD, William, Jr. (1952). "The End Of The I.T.O.", Princeton Essays In International Finance, v. 16.

DIEHL, Paul F. / Charlotte KU / Daniel ZAMORA (2003). "The Dynamics of International Law: The Interaction of Normative and Operating Systems", International Organization, v. 57, pp. 43-75.

DOWLING Joanmarie M. / Mark P. POPIEL (2003). "War By Sanctions: Are We Targeting Ourselves?”, Currents International Trade Law Journal, v. 11 p. 8-38.

DOWNS, George W. / David M. ROCKE / Peter N. BARSOOM (1996). "Is the Good News about Compliance Good News about Cooperation?”, International Organization, v. 50, n. 3, pp. 379-406.

DOWNS, George W. / David M. ROCKE / Peter N. BARSOOM (1998). "Managing the Evolution of Multilateralism”, International Organization, v. 52, pp. 397-419, 1998.

DOWNS, George W. / Kyle W. DANISH / Peter N. BARSOOM (2000). "The Transformational Model of International Regime Design: Triumph of Hope or Experience?", Columbia Journal of Transnational Law, v. 38, pp. 465-509.

DREZNER, Daniel W. (2003). “The Hidden Hand of Economic Coercion”, International Organization, v. 57, pp. 643-659.

DUNOFF, Jeffrey (2006). "Lotus Eaters: Reflections on the Varietals Dispute, the SPS Agreement and WTO Dispute Resolution", in BERMANN, George A. / Petros C. MAVROIDIS [ed.], Trade and Human Health and Safety. New York (NY), Cambridge University Press, pp. 153-187.

ESSERMAN, Susan / Robert HOWSE (2003), “The WTO on Trial”, Foreign Affairs, v. 82, n.1, pp. 130-140. 
FORD, Rosemary A. (2002). "The Beef Hormone Dispute and Carousel Sanctions: a Roundabout Way of Forcing Compliance with World Trade Organization Decisions", Brooklyn Journal of International Law, New York, v. 27, pp. 543-574.

FUKUNAGA, Yuka (2006). "Securing Compliance Through The WTO Dispute Settlement System: Implementation Of DSB Recommendations", Journal of International Economic Law, v. 9, n. 2, pp. 383-426.

GALAM, Serge (1998). "Comment on 'A Landscape Theory of Aggregation"”, British Journal of Political Science, v. 28, n. 2, pp. 411-412.

GARDNER, Richard N. (1996). "The Bretton Woods - GATT System after Fifty Years: A Balance Sheet of Success and Failure", in KIRSHNER, Orin [ed.]. The Bretton WoodsGatt System: Retrospect And Prospect After Fifty Years Armonk, New York, M.E. Sharpe. GARRETT, Geoffrey / James McCall SMITH (2002). “The Politics of WTO Dispute Settlement", UCLA International Institute - Occasional Paper Series, in http://repositories.cdlib.org/cgi/viewcontent.cgi?article=1000\&context=international, acessado em 22 de janeiro de 2011.

GOWA, Joanne / Edward D. MANSFIELD (2004). “Alliances, Imperfect Markets, and Major-Power Trade", International Organization, v. 58, p. 775-805.

GRANE, Patricio (2001). "Remedies Under WTO Law", 4 J. Journal of International Economic Law, vol. 4, pp. 755-772.

GRANE, Patricio / John H. JACKSON (2001). "The Saga Continues: An Update on the Banana Dispute and its Procedural Offspring", Journal of International Economic Law, v. 4, pp. 581-595.

GREENWALD, John (2003). "WTO Dispute Settlement: An Exercise In Trade Law Legislation?", Journal of International Economic Law, v. 6, n. 1, pp. 113-124.

GRIECO, Joseph M. / Christopher F. GELPI / T. Camber WARREN (2009). "When Preferences and Commitments Collide: The Effect of Relative Partisan Shifts on International Treaty Compliance”, International Organization, v. 63, p. 341-355.

GUZMAN, Andrew T. (2002). "A Compliance-Based Theory of International Law", California Law Review, Berkeley, v. 90, pp. 1823-1888.

HAGGARD, Stephan / Beth A. SIMMONS (1987). "Theories of International Regimes", International Organization, v. 41, n. 3, pp. 491-517.

HIRSHLEIFER, Jack (1982). "Evolutionary Models in Economics and Law: Cooperation Versus Conflict Strategies", Research in Law and Economics, v. 4, pp. 1-60. 
HUDEC, Robert E. (2000). "Broadening the Scope of Remedies in WTO Dispute Settlement", in WEISS, Friedl / Jochem WIERS. Improving WTO Dispute Settlement Procedures. London, Cameron May, pp. 345-376.

HUDEC, Robert E. (1980). "GATT Dispute Settlement after the Tokyo Round: An Unfinished Business", Cornell International Law Journal, v. 13, pp. 153-156.

HUDEC, Robert E. (1990). "Thinking About the New Section 301: Beyond Good and Evil”, in BHAGWATI, J.; PATRICK, H. T. (eds), Aggressive Unilateralism: America's 301 Trade Policy And The World Trade System. Ann Arbor, The University of Michigan Press.

HUDEC, Robert E. (1998). "Reforming GATT Adjudication Procedures: The Lessons of the DISC Case". Minnesota Law Review, v. 72, p. 1443-1509.

HUNGERFORD, Thomas L. (1991). "GATT: A Cooperative Equilibrium in a Noncooperative Trading Regime?”, Journal Of International Economics, v. 31, pp. $357-$ 369.

IIDA, Keisuke (2004). "Is WTO Dispute Settlement Effective?", Global Governance, v. 10, pp. 207-266.

JACKSON, John H. (1997). "The WTO Dispute Settlement Understanding Misunderstandings on the Nature of Legal Obligations", American Journal of International Law, v. 91, p. 60-64.

JACKSON, John H. (2004). "International Law Status of WTO Dispute Settlement Reports: Obligation to Comply or Option to "Buy Out"?", American Journal of International Law, n. 98, pp. 109-125.

JERVIS, Robert (1985). "From Balance to Concert: A Study of International Security Cooperation", World Politics, v. 38, pp. 58-107.

JERVIS, Robert (2009). “Unipolarity: A Structural Perspective”, World Politics, v. 61, n. 1, p. 188-213.

KELLY, Claire R. (2005). "Enmeshment as a Theory of Compliance", New York University Journal of International Law and Politics, New York, v. 37, n. 2, pp. 303-356.

KEOHANE, Robert O. (1982). "The Demand for International Regimes," in KRASNER, Stephen D. [ed.] International Regimes. Ithaca, Cornell University Press.

KEOHANE Reohane O. / Joseph S. NYE (1974). "Transgovernmental Relations and International Organizations", World Politics, v. 27, pp. 39-62. 
KINGSBURY, Benedict (1998). "The Concept of Compliance as a Function of Competing Conceptions of International Law", Michigan Journal of International Law, Ann Arbor, v. 19, pp. 345-372.

KOH, Harold H. (1995). “The 1994 Roscoe Pound Lecture: Transnational Legal Process”, Nebraska Law Review, v. 76, pp. 180-206.

KOH, Harold H. (1997). “Why Do Nations Obey International Law?”, Yale Law Journal, v. 106, p. 2599-2659.

KOREMENOS, Barbara (2007). "If Only Half of International Agreements Have Dispute Resolution Provisions, Which Half Needs Explaining?", The Journal of Legal Studies, Chicago, v. 36, n. 1, pp. 189-212.

KOVENOCH, Dan / Marie THURSBY (1993). "GATT Dispute Settlement and Cooperation", Economics And Politics, v. 4, p. 151-170.

KRASNER, Stephen D. (1982). "Regimes and the Limits of Realism: Regimes as Autonomous Variables", International Organization, v. 36, n. 2, International Regimes, pp. 497-510.

KRASNER, Stephen D. (1982). "Structural Causes and Regime Consequences: Regimes as Intervening Variables", in Id. [ed.], International Regimes. Ithaca: Cornell University Press, pp. 1-22.

KREPS, Sarah Elizabeth; Anthony Clark AREND (2006). "Why States Follow the Rules: Toward a Positional Theory of Adherence to International Legal Regimes". Duke Journal of Comparative \& International Law, Durham, v. 16, n. 2, pp. 331-414.

LEEBRON, David W. (2002). "Linkages”, American Journal of International Law, v. 96, pp. 5-27, 2002.

LEEDS, Brett Ashley (2003). "Alliance Reliability in Times of War: Explaining State Decisions to Violate Treaties", International Organization, v. 57, n. 4, pp. 801-827.

LEIRER, Wolfgang W. (1994). "Retaliatory Action in United States and European Union Trade Law: A Comparison of Section 301 of the Trade Act of 1974 and Council Regulation 2641/84", North Carolina Journal of International Law and Commercial Regulation, v. 20, pp. 41.

LEKTZIAN, David / Mark SOUVA (2003). "The Economic Peace between Democracies: Economic Sanctions and Domestic Institutions", Journal of Peace Research, v. 40, n. 6, pp. 641-660. 
LIPSON, Charles (1982). "The Transformation of Trade: the Sources and Effects of Regime Change”, in KRASNER, Stephen D. [ed.] International Regimes. Ithaca, Cornell University Press.

IIDA, K. “Is WTO Dispute Settlement Effective?” Global Governance, v. 10, pp. 207-266, abril 2004.

LIMÃO, Nuno / Kamal SAGGI (2006). "Tariff Retaliation versus Financial Compensation in the Enforcement of International Trade Agreements", World Bank Policy Research Working Paper, $\quad$ n. 3873, http://econ.worldbank.org/external/default/main?pagePK $=64165259 \&$ theSitePK $=469382 \&$ piPK $=64165421 \&$ menuPK $=64166093 \&$ entity $I D=000160016 \_20060324163518$, acessado em 22 de janeiro de 2011.

LONG, Andrew G.; B. Ashley LEEDS (2006). "Trading for Security: Military Alliances and Economic Agreements", Journal of Peace Research, v. 43, n. 4, Special Issue on Alliances, pp. 433-451.

LOWENFELD, Andreas F. (1973). 'Doing Unto Others...'-The Chicken War Ten Years After", Journal Of Maritime Law And Commerce, v. 4, pp. 599.

MAGGI, Giovanni (1999). “The Role of Multilateral Institutions in International Trade Cooperation", The American Economic Review, v. 89, p. 190-214.

MATON, John; MATON, Carolyn (2007). "Independence Under Fire: Extra-Legal Pressures and Coalition Building in WTO Dispute Settlement", Journal of International Economic Law, Oxford, v. 10, n. 2, pp. 317-334.

MAVROIDIS, Petros C. (2000). "Remedies in the WTO Legal System: Between a Rock and a Hard Place", European Journal of International Law, v. 11, n. 4, pp. 763-813.

MCRAE, Donald (2008). "Measuring the Effectiveness of the WTO Dispute Settlement System", Asian Journal of WTO \& International Health Law \& Policy, Taipei, v. 3, n. 1, pp. 1-20.

MITCHELL, Andrew D. (2006). "Proportionality and Remedies in WTO Disputes", European Journal of International Law, v. 17, n. 5, pp. 985-1008.

MITCHELL, Ronald B. / Patricia M. KEILBACH (2001). "Situation Structure and Institutional Design: Reciprocity, Coercion and Exchange”, International Organization, v. 55, pp. 891-917.

MORA, Miguel Montana i (1993). “A GATT With Teeth: Law Wins Over Politics in the Resolution of International Trade Disputes", Columbia Journal of Transnational Law, v. 31, pp. 131-161. 
MORROW, James D.(1988) "Social Choice and System Structure in World Politics", World Politics, v. 41, pp. 75-97.

MOSOTI, Victor (2006). "Africa in the First Decade of WTO Dispute Settlement", Journal of International Economic Law, v. 9, n. 2, pp. 427-453.

MOVSESIAN, Mark L. (2004). "Enforcement of WTO Rulings: an Interest Group Analysis", Hofstra Law Review, Hempstead, v. 32, pp. 1-22.

NELSON, Richard R. / Sidney G. WINTER (1982). "Skills", in Id., An Evolutionary Theory of Economic Change. Cambridge (MA), The Belknap Press of Harvard University Press, pp. 72-136.

NZELIBE, Jide (2008). "The Case Against Reforming the WTO Enforcement Mechanism”, University of Illinois Law Review, Champaign, v. 2008, n. 1, pp. 319-357, 2008.

OLSON, Mancur / Richard ZECKHAUSER (1966). "An Economic Theory of Alliances”, Review of Economics and Statistics, v. 48, pp. 266-279.

OSTROM, Elinor (2000). "Collective Action and the Evolution of Social Norms", The Journal of Economic Perspectives, v. 14, n. 3, pp. 137-158.

OYE, Kenneth A. (1985). "Explaining Cooperation Under Anarchy: Hypotheses and Strategies", World Politics, v. 38. n. 1, pp. 1-24.

PALMETER, N. David (1990). "Section 301: The Privatization of Retaliation", Transnational Lawyer, v. 3, p. 101.

PALMETER, N. David (2000). "The WTO as a Legal System", Fordham International Law Journal, v. 24, pp. 444-480.

PAUWELYN, Joost (2000). "Enforcement and Countermeasures in the WTO: Rules Are Rules - Toward a More Collective Approach”. American Journal of International Law, Washington, v. 94, pp. 335-347.

PAUWELYN, Joost (2003b). “A Typology of Multilateral Treaty Obligations: Are WTO Obligations Bilateral or Collective in Nature?", European Journal of International Law, v. 14, pp. 907-952.

PEREZ, Oren (2005). "Multiple Regimes, Issue Linkage, and International Cooperation: Exploring the Role of the WTO”. University of Pennsylvania Journal of International Economic Law, Philadelphia, v. 26, pp. 735-778.

PETERSMANN, Ernst-Ulrich (2006). "Justice as Conflict Resolution: Proliferation, Fragmentation, and Decentralization of Dispute Settlement in International Trade", 
University of Pennsylvania Journal of International Economic Law, Philadelphia, v. 27, pp. 273-366.

PETERSMANN, Ernst-Ulrich (2008). "Why Rational Choice Theory Requires a Multilevel Constitutional Approach to International Economic Law - A Response to the Case Against Reforming the WTO Enforcement Mechanism", University of Illinois Law Review, Champaign, v. 2008, n. 1, pp. 359-382.

POSNER, Eric A / John C. YOO (2005). "Reply to Helfer and Slaughter", California Law Review, Berkeley, v. 93, pp. 957-974.

POWERS, Kathy L. (2006). "Dispute Initiation and Alliance Obligations in Regional Economic Institutions”, Journal of Peace Research, v. 43, n. 4, Special Issue on Alliances, pp. 453-471.

PUTNAM Robert D. (1988). "Diplomacy and Domestic Politics: the Logic of Two-Level Games”, International Organization, v. 42, pp. 427-460.

RAGOSTA, John / Navin JONEJA / Mikhail ZELDOVICH (2003). "WTO Dispute Settlement: the System is Flawed and Must Be Fixed", The International Lawyer, Washington, v. 37, n. 3, pp. 697-752.

RAUSTIALA, Kal (2000). “Compliance \& Effectiveness in International Regulatory Cooperation”, Case Western Reserve Journal of International Law, v. 32, 387-440.

RAUSTIALA, Kal (2002). "The Architecture of International Cooperation: Transgovernmental Networks and the Future of International Law", Virginia Journal of International Law, v. 43, pp. 1-92.

REICH, Arie (1997). "From Diplomacy to Law: The Juridicization of International Trade Relations", Northwestern Journal of International Law \& Business, v. 17, pp. 775-849.

ROSAS, Allan (2001), "Implementation and Enforcement of WTO Dispute Settlement Findings: an EU Perspective", Journal of International Economic Law, v. 4, n. 1, pp. 131144.

ROSENDORFF, Peter / Helen V. MILNER (2001). "The Optimal Design of International Trade Institutions: Uncertainty and Escape”, International Organization, v. 55, pp. 829858.

RUGGIE, John G. (1982). "International Regime, Transactions, and Change: Embedded Liberalism In The Postwar Economic Order," in KRASNER, Stephen D. [ed.]. International Regimes. Ithaca, Cornell University Press.

RUNGE, Carlisle Ford (1984). "Institutions and the Free Rider: The Assurance Problem in Collective Action", Journal of Politics, v. 46, n. 1, pp. 154-181. 
SCHWARTZ, Warren F. / Allan O. SYKES (2002)., "The Economic Structure of Renegotiation and Dispute Resolution in the World Trade Organization", Journal of Legal Studies, v. 31, pp. 179-204.

SETEAR, John K. (1996), “An Iterative Perspective on Treaties: A Synthesis of International Relations Theory and International Law", Harvard International Law Journal, v. 37, pp. 139-229.

SHAFFER, Gregory (2003)., "How to Make the WTO Dispute Settlement System Work for Developing Countries", ICTSD Resource Paper, n. 5, in http://kms1.isn.ethz.ch/serviceengine/Files/ISN/92860/ichaptersection_singledocument/6fc 9b1ec-ade2-4df3-9862-

2a7516fefad4/en/No_05_chapter_1_+Towards_a_Development_pdf, acessado em 22 de janeiro de 2011.

SHELL, G. Richard (1995), "Trade Legalism and International Relations Theory: An Analysis of the World Trade Organization”, Duke Law Journal, v. 44, pp. 829-927.

SHOYER, Andrew / Eric SOLOVY / Alexander KOFF (2005). "Implementation and Enforcement of the WTO Agreements", in Patrick MACRORY / Arthur APPLETON / Michael PLUMMER [eds]. The World Trade Organization: Legal, Economic and Political Analysis.New York: Springer.

SILVERMAN, Jared R. (1996). "Multilateral Resolution over Unilateral Retaliation: Adjudicating the Use of Section 301 Before the WTO", University of Pennsylvania Journal of International Economic Law, v. 17, pp. 233-294.

SIMMONS, Beth A. (2000). "Money and the Law: Why Comply with the Public International Law of Money?", Yale Journal of International Law, New Haven, v. 25, pp. 323-362.

SINGER, J. David / SMALL, Melvin (1966). “Formal Alliances, 1815-1939”, Journal of Peace Research, v. 3, pp. 1-31.

SMALL, Melvin / SINGER, J. David (1969). "Formal Alliances, 1815-1965: An Extension of the Basic Data", Journal of Peace Research, v. 6, pp. 257-82.

SMITH, James McCall (2000). "The Politics of Dispute Settlement Design: Explaining Legalism in Regional Trade Pacts”, International Organization, v. 54, pp. 137-180. SNIDAL, Duncan (1985). "The Game Theory of International Politics", World Politics, v. 38 , pp. $25-57$. 
SNIDAL, Duncan (1985b). “Coordination versus Prisoners' Dilemma: Implications for International Cooperation and Regimes." The American Political Science Review, v. 79, p. 923-942.

SNYDER, Glenn H. (1984). "The Security Dilemma in Alliance Politics", World Politics, v. 36, pp. 461-496.

SPAMANN, Holger (2006). “The Myth Of 'Rebalancing' Retaliation In WTO Dispute Settlement Practice", Journal of International Economic Law, Oxford, v. 9, n. 1, pp. 31-79. STEIN, Arthur A. (1982). "Coordination and Collaboration: Regimes in an Anarchic World”, in KRASNER, S. D. (ed.), International Regimes. Ithaca, Cornell University Press.

STEINBERG, Richard H. (2002). "In the Shadow of Law or Power? Consensus-Based Bargaining and Outcomes in the GATT/WTO”, International Organization, v. 56, 339374.

STEINBERG, Richard H. (2004). "Judicial Lawmaking at the WTO: Discursive, Constitutional, and Political Constraints", American Journal of International Law, v. 98, pp. 247-275.

STEWART, Terence / Amy S. DWYER / Elizabeth M. HEIN (2007). "Trends in the Last Decade of Trade Remedy Decisions: Problems and Opportunities for the WTO Dispute Settlement System". Arizona Journal of International and Comparative Law, Tucson, v. 24, n. 1, pp. 251-298.

STOLER, Andrew L. (2004). "The WTO Dispute Settlement Process: Did the Negotiators Get What They Wanted?”, World Trade Review, v. 3, n. 1, pp. 99-118.

SYKES, Allan O. (1992). "Constructive Unilateral Threats in International Commercial Relations: The Limited Case for Section 301", Law and Policy in International Business, v. 23, pp. 263-330.

SYKES, Allan O. (2000). "The Remedy for Breach of Obligations under the WTO Dispute Settlement Understanding: Damages or Specific Performance?”, in Marco BRONCKERS / Reinhard QUICK. New directions in international economic law: essays in honour of John H. Jackson. The Hague; Boston, Kluwer Law International.

TESON, Fernando R. (1992). "The Kantian Theory of International Law”, Columbia Law Review, v. 92, pp. 53-102.

THATCHER, K. Blake (1987). "Section 301 of the Trade Act of 1974: Its Utility Against Alleged Unfair Trade Practices by the Japanese Government", Northwestern University Law Review, v. 81 pp. 492-495. 
TRACHTMAN, Joel P. (1997). "The Theory of the Firm and the Theory of the International Economic Organization: Toward Comparative Institutional Analysis", Northwestern Journal of International Law \& Business, v. 17, pp. 470-555.

TRACHTMAN, Joel P. (1999). "The Domain of WTO Dispute Resolution", Harvard International Law Journal, v. 40, pp. 333-378, 1999.

TRACHTMAN, Joel P. (2007). "The WTO Cathedral”. Stanford Journal of International Law, v. 43, pp. 127-168.

VERDIER, Pierre-Hughes (2002). "Cooperative States: International Relations, State Responsibility and The Problem of Custom", Virginia Journal of International Law, Charlottesville, v. 42 839-867, 2002.

WALKER, Herman (1964). “Dispute Settlement: The Chicken War", American Journal of International Law, v. 57, p. 671-675.

WALT, Stephen M. (2009). “Alliances in a Unipolar World”, World Politics, v. 61, n. 1, pp. 86-120.

WALT, Stephen M. (1988). "Testing Theories of Alliance Formation: The Case of Southwest Asia", International Organization, v. 42, pp. 275-316.

YOUNG, Oran R. (1980), “International Regimes: Problems of Concept Formation”, World Politics, v. 32, n. 3, pp. 331-356. 
ANEXO A

Tabela 11 - Poderio Nacional de Maiores Usuários do SSC/OMC

\begin{tabular}{|c|c|c|c|c|c|c|c|c|c|c|c|c|}
\hline Pais & \begin{tabular}{|l} 
PIB per capita \\
PPP 2010 \\
(dólares) \\
\end{tabular} & $\begin{array}{l}\text { População } \\
\text { (milhares de } \\
\text { pessoas) }\end{array}$ & \begin{tabular}{|l} 
PIB 2010 PPP \\
(milhôes de \\
dólares)
\end{tabular} & $\begin{array}{l}\text { Exportação de } \\
\text { mercadoria }\end{array}$ & $\begin{array}{l}\text { Exportação de } \\
\text { serviço }\end{array}$ & $\begin{array}{l}\text { Exportação de } \\
\text { Mercadorias e } \\
\text { Serviços }\end{array}$ & $\begin{array}{l}\text { Importação de } \\
\text { mercadoria }\end{array}$ & $\begin{array}{l}\text { Importação de } \\
\text { serviço }\end{array}$ & $\begin{array}{l}\text { Importação de } \\
\text { Mercadorias e } \\
\text { Serviços }\end{array}$ & $\begin{array}{l}\text { Corrente de } \\
\text { Comércio }(M+S)\end{array}$ & $\begin{array}{l}\text { PIB } \times \text { Corrente de } \\
\text { Comércio }\end{array}$ & $\begin{array}{l}\text { Tamanho } \\
\text { (capacidades) }\end{array}$ \\
\hline UE & 30294,31 & 500116 & 15150667,00 & 1528,00 & \begin{tabular}{|l}
652,00 \\
\end{tabular} & 2180,00 & 1673,00 & 543,00 & 2216,00 & \begin{tabular}{|l|}
4396,00 \\
\end{tabular} & 66602332132 & 1000000 \\
\hline EUA & 47131,91 & 310282 & 14624184,00 & 1056,00 & 474,00 & 1530,00 & 1605,00 & 331,00 & 1936,00 & 3466,00 & 50687421744 & 761046 \\
\hline China & 7517,72 & 1341414 & 10084369,00 & 1202,00 & 129,00 & 1331,00 & 1006,00 & 158,00 & 1164,00 & 2495,00 & 25160500655 & 377772 \\
\hline Japão & 33828,18 & 127368 & 4308627,00 & 581,00 & 126,00 & 707,00 & 552,00 & 147,00 & 699,00 & 1406,00 & 6057929562 & 90957 \\
\hline Coreia do Sul & 29790,70 & 48910 & 1457063,00 & 364,00 & 57,00 & 421,00 & 323,00 & 75,00 & 398,00 & 819,00 & 1193334597 & 17917 \\
\hline Canadá & 39033,51 & 34076 & 1330106,00 & 317,00 & 58,00 & 375,00 & 330,00 & 78,00 & 408,00 & 783,00 & 1041472998 & 15637 \\
\hline Rússia* & 15806,88 & 140367 & 2218764,00 & 303,00 & 41,00 & 344,00 & 192,00 & 59,00 & 251,00 & 595,00 & 1320164580 & 19822 \\
\hline México & 14265,98 & 108627 & 1549671,00 & 230,00 & 15,00 & 245,00 & 242,00 & 21,00 & 263,00 & 508,00 & 787232868 & 11820 \\
\hline Índia & 3290,55 & 1215939 & 4001103,00 & 163,00 & 87,00 & 250,00 & 250,00 & 80,00 & 330,00 & 580,00 & 2320639740 & 34843 \\
\hline Taipé Chinesa & 33702,16 & 23328 & 786204,00 & 204,00 & 31,00 & 235,00 & 174,00 & 29,00 & 203,00 & 438,00 & 344357352 & 5170 \\
\hline Australia & 39691,59 & 22230 & 882344,00 & 154,00 & 41,00 & 195,00 & 165,00 & 41,00 & 206,00 & 401,00 & 353819944 & 5312 \\
\hline Brasil & 11289,23 & 193253 & 2181677,00 & 153,00 & 26,00 & 179,00 & 134,00 & 44,00 & 178,00 & 357,00 & 778858689 & 11694 \\
\hline Tailândia & 8643,64 & 67653 & 584768,00 & 152,00 & 30,00 & 182,00 & 134,00 & 38,00 & 172,00 & 354,00 & 207007872 & 3108 \\
\hline Turquia & 13050,89 & 71428 & 932199,00 & 102,00 & 33,00 & 135,00 & 141,00 & 16,00 & 157,00 & 292,00 & 272202108 & 4087 \\
\hline Indonésia & 4379,66 & 234557 & 1027279,00 & 119,00 & 13,00 & 132,00 & 92,00 & 28,00 & 120,00 & 252,00 & 258874308 & 3887 \\
\hline Noruega & 52965,45 & 4891 & 259054,00 & 121,00 & 38,00 & 159,00 & 69,00 & 38,00 & 107,00 & 266,00 & 68908364 & 1035 \\
\hline Hungria** & 18730,35 & 9976 & 186854,00 & 84,00 & 18,00 & 102,00 & 78,00 & 16,00 & 94,00 & 196,00 & 36623384 & 550 \\
\hline Venezuela & 2398,90 & 29183 & 70007,00 & 68,00 & 2,00 & 70,00 & 41,00 & 9,00 & 50,00 & 120,00 & 8400840 & 126 \\
\hline Chile & 14939,67 & 17190 & 256813,00 & 54,00 & 8,00 & 62,00 & 42,00 & 9,00 & 51,00 & 113,00 & 29019869 & 436 \\
\hline Argentina & 15603,12 & 40519 & 632223,00 & 56,00 & 11,00 & 67,00 & 39,00 & 11,00 & 50,00 & 117,00 & 73970091 & 1111 \\
\hline Filipinas & 3603,52 & 94013 & 338778,00 & 38,00 & 10,00 & 48,00 & 46,00 & 8,00 & 54,00 & 102,00 & 34555356 & 519 \\
\hline Colômbia & 9091,81 & 45518 & 413841,00 & 33,00 & 4,00 & 37,00 & 33,00 & 7,00 & 40,00 & 77,00 & 31865757 & 478 \\
\hline Nova Zelândia & 27363,01 & 4369 & 119549,00 & 25,00 & 8,00 & 33,00 & 26,00 & 8,00 & 34,00 & 67,00 & 8009783 & 120 \\
\hline Peru & 9107,40 & 29552 & 269142,00 & 27,00 & 4,00 & 31,00 & 22,00 & 5,00 & 27,00 & 58,00 & 15610236 & 234 \\
\hline Equador & 8022,01 & 14314 & 114827,00 & 14,00 & 1,00 & 15,00 & 15,00 & 3,00 & 18,00 & 33,00 & 3789291 & 57 \\
\hline Costa Rica & 10687,66 & 4764 & 50916,00 & 9,00 & 4,00 & 13,00 & 11,00 & 2,00 & 13,00 & 26,00 & 1323816 & 20 \\
\hline \begin{tabular}{l|l} 
Guatemala \\
\end{tabular} & 4874,46 & 14362 & 70007,00 & 7,00 & 1,00 & 8,00 & 11,00 & 2,00 & 13,00 & 21,00 & 1470147 & 22 \\
\hline Rep. Dominican & 9139,07 & 9161 & 83723,00 & 5,00 & 5,00 & 10,00 & 12,00 & 1,00 & 13,00 & 23,00 & 1925629 & 29 \\
\hline Costa do Marfim & 1685,42 & 22026 & 37123,00 & 8,00 & 1,00 & 9,00 & 6,00 & 2,00 & 8,00 & 17,00 & 631091 & 9 \\
\hline \begin{tabular}{l|} 
Gana \\
\end{tabular} & 1591,08 & 23699 & 37707,00 & 6,00 & 2,00 & 8,00 & 8,00 & 2,00 & 10,00 & 18,00 & 678726 & 10 \\
\hline Honduras & 4175,03 & 7993 & 33371,00 & 5,00 & 1,00 & 6,00 & 8,00 & 1,00 & 9,00 & 15,00 & 500565 & 8 \\
\hline Senegal & 1772,85 & 13128 & 23274,00 & 2,00 & 1,00 & 3,00 & 5,00 & 2,00 & 7,00 & 10,00 & 232740 & 3 \\
\hline Camarōes & 2163,34 & 20424 & 44184,00 & 3,00 & 1,00 & 4,00 & 4,00 & 2,00 & 6,00 & 10,00 & 441840 & 7 \\
\hline Jamaica & 8771,29 & 2724 & 23893,00 & 1,00 & 3,00 & 4,00 & 5,00 & 2,00 & 7,00 & 11,00 & 262823 & 4 \\
\hline Nicarágua & 2635,87 & 6462 & 17033,00 & 1,00 & - & 1,00 & 3,00 & 1,00 & 4,00 & 5,00 & 85165 & 1 \\
\hline Madagascar & 905,44 & 21299 & 19285,00 & 1,00 & 1,00 & 2,00 & 3,00 & 1,00 & 4,00 & 6,00 & 115710 & 2 \\
\hline Suriname & 8946,97 & 528 & 4724,00 & 1,00 & - & 1,00 & 1,00 & - & 1,00 & 2,00 & 9448 & 0 \\
\hline \begin{tabular}{|l|} 
Beliza \\
\end{tabular} & 7626,47 & 340 & 2593,00 & - & - & - & 1,00 & - & 1,00 & 1,00 & 2593 & 0 \\
\hline Antigua e Barbud & 1745,35 & 860 & 1501,00 & - & 1,00 & 1,00 & 1,00 & - & 1,00 & 2,00 & 3002 & 0 \\
\hline Dominica & 10424,66 & 73 & 761,00 & - & - & - & - & - & - & - & - & - \\
\hline Santa Lúcia & 10277,46 & 173 & 1778,00 & - & - & - & - & - & - & - & - & - \\
\hline S. Vicente e Grat & 10102,80 & 107 & 1081,00 & - & - & - & - & - & - & - & - & - \\
\hline \begin{tabular}{|l|l} 
Granada & \\
\end{tabular} & 10873,79 & 103 & 1120,00 & - & - & - & - & - & - & - & - & - \\
\hline
\end{tabular}




\section{ANEXO B \\ Tabela 12 - Tipologia dos Interesses Invocados pelas Terceiras-Partes}

Posicionamentos apresentados pelas terceiras partes durante as reuniões de instauração dos painéis que levaram a autorização para retaliações

\begin{tabular}{|c|c|c|c|c|}
\hline Caso: & \multicolumn{4}{|c|}{ CE-Bananas III [DS27] } \\
\hline Demandante: & \multicolumn{4}{|c|}{ Equador, Guatemala, Honduras, México, EUA } \\
\hline Demandado: & \multicolumn{4}{|c|}{$\mathrm{CE}$} \\
\hline Terceiras partes: & $\begin{array}{c}\text { Interesses } \\
\text { comerciais }\end{array}$ & $\begin{array}{l}\text { Interesse } \\
\text { sistêmico }\end{array}$ & $\begin{array}{c}\text { Mera reserva de } \\
\text { direitos }\end{array}$ & $\begin{array}{c}\text { Sem } \\
\text { manifestação }\end{array}$ \\
\hline Belize & $\mathrm{X}$ & & & \\
\hline Camarões & $\mathrm{X}$ & & & \\
\hline Canadá & & $\mathrm{X}$ & & \\
\hline Colômbia & $\mathrm{X}$ & & & \\
\hline Costa Rica & $\mathrm{X}$ & & & \\
\hline Domínica & $\mathrm{X}$ & & & \\
\hline Rep. Dominicana & $\mathrm{X}$ & & & \\
\hline Gana & $\mathrm{X}$ & & & \\
\hline Granada & $\mathrm{X}$ & & & \\
\hline Índia & $\mathrm{X}$ & & & \\
\hline Jamaica & $\mathrm{X}$ & & & \\
\hline Japão & & & $\mathrm{X}$ & \\
\hline Nicarágua & $\mathrm{X}$ & & & \\
\hline Filipinas & & & $\mathrm{X}$ & \\
\hline Santa Lúcia & $\mathrm{X}$ & & & \\
\hline $\begin{array}{l}\text { São Vicente e } \\
\text { Granadinas }\end{array}$ & $\mathrm{X}$ & & & \\
\hline Senegal & X & & & \\
\hline Suriname & $\mathrm{X}$ & & & \\
\hline Venezuela & $\mathrm{X}$ & & & \\
\hline Costa do Marfim & $\mathrm{X}$ & & & \\
\hline Brasil & & & & $\mathrm{X}$ \\
\hline Madagascar & & & & $\mathrm{X}$ \\
\hline Panamá & & & & $\mathrm{X}$ \\
\hline
\end{tabular}




\begin{tabular}{|c|c|c|c|c|}
\hline Caso: & \multicolumn{4}{|c|}{ CE-Hormônios [DS26] } \\
\hline Demandante: & \multicolumn{4}{|c|}{ EUA } \\
\hline Demandado: & \multicolumn{4}{|l|}{$\mathrm{CE}$} \\
\hline Terceiras partes: & $\begin{array}{c}\begin{array}{c}\text { Interesses } \\
\text { comerciais }\end{array} \\
\end{array}$ & $\begin{array}{l}\text { Interesse } \\
\text { sistêmico }\end{array}$ & $\begin{array}{c}\text { Mera reserva de } \\
\text { direitos }\end{array}$ & $\begin{array}{c}\text { Sem } \\
\text { manifestação }\end{array}$ \\
\hline Austrália & & & $\mathrm{X}$ & \\
\hline Canadá & & & $\mathrm{X}$ & \\
\hline Nova Zelândia & & & $\mathrm{X}$ & \\
\hline \begin{tabular}{|l} 
Noruega \\
\end{tabular} & & & $\mathrm{X}$ & \\
\hline
\end{tabular}

\begin{tabular}{|c|c|c|c|c|}
\hline Caso: & \multicolumn{4}{|c|}{ CE - Hormônios [DS48] } \\
\hline Demandante: & \multicolumn{4}{|c|}{ Canadá } \\
\hline Demandado: & \multicolumn{4}{|l|}{$\mathrm{CE}$} \\
\hline Terceiras partes: & $\begin{array}{c}\text { Interesses } \\
\text { comerciais }\end{array}$ & $\begin{array}{l}\text { Interesse } \\
\text { sistêmico }\end{array}$ & $\begin{array}{c}\text { Mera reserva de } \\
\text { direitos }\end{array}$ & $\begin{array}{c}\text { Sem } \\
\text { manifestação }\end{array}$ \\
\hline Austrália & & & $\mathrm{X}$ & \\
\hline Nova Zelândia & & & $\mathrm{X}$ & \\
\hline Noruega & & & $\mathrm{X}$ & \\
\hline EUA & & & $\mathrm{X}$ & \\
\hline
\end{tabular}




\begin{tabular}{|l|l|l|c|c|}
\hline Caso: & \multicolumn{3}{|l|}{ Brasil-Aviões [DS46] } \\
\hline Demandante: & EUA & \multicolumn{3}{|l|}{} \\
\hline Demandado: & CE & \multicolumn{3}{|l|}{} \\
\hline Terceiras partes: & $\begin{array}{c}\text { Interesses } \\
\text { comerciais }\end{array}$ & $\begin{array}{c}\text { Interesse } \\
\text { sistêmico }\end{array}$ & $\begin{array}{c}\text { Mera reserva de } \\
\text { direitos }\end{array}$ & $\begin{array}{c}\text { Sem } \\
\text { manifestação }\end{array}$ \\
\hline & & & & $\mathrm{X}$ \\
\hline Austrália & & & & $\mathrm{X}$ \\
\hline UE & & & $\mathrm{X}$ & $\mathrm{X}$ \\
\hline Coreia do Sul & & & & \\
\hline EUA & & & & \\
\hline
\end{tabular}

\begin{tabular}{|l|l|l|c|c|}
\hline Caso: & \multicolumn{4}{|l|}{ Canadá - Créditos e Garantias para Aviões [DS222] } \\
\hline Demandante: & Brasil & \multicolumn{3}{|l|}{} \\
\hline Demandado: & Canadá & $\begin{array}{c}\text { Sem } \\
\text { manifestação }\end{array}$ \\
\hline Terceiras partes: & $\begin{array}{c}\text { Interesses } \\
\text { comerciais }\end{array}$ & $\begin{array}{c}\text { Interesse } \\
\text { sistêmico }\end{array}$ & $\begin{array}{c}\text { Mera reserva de } \\
\text { direitos }\end{array}$ & X \\
\hline & & & & \\
\hline Austrália & & & $\mathrm{X}$ & \\
\hline UE & & & $\mathrm{X}$ & \\
\hline Índia & & & & \\
\hline EUA & & & &
\end{tabular}




\begin{tabular}{|l|l|l|l|l|}
\hline Caso: & \multicolumn{4}{|l|}{} \\
\hline Demandante: & CE & \multicolumn{3}{l|}{} \\
\hline Demandado: & EUA & $\begin{array}{c}\text { Interesse } \\
\text { sistêmico }\end{array}$ & $\begin{array}{c}\text { Mera reserva de } \\
\text { direitos }\end{array}$ & $\begin{array}{c}\text { Sem } \\
\text { manifestação }\end{array}$ \\
\hline Terceiras partes: & $\begin{array}{c}\text { Interesses } \\
\text { comerciais }\end{array}$ & & & $\mathrm{X}$ \\
\hline Austrália & & & & $\mathrm{X}$ \\
\hline Brasil & & & $\mathrm{X}$ & $\mathrm{X}$ \\
\hline Canadá & & & $\mathrm{X}$ & \\
\hline Japão & & & & \\
\hline Suíça & & & & \\
\hline
\end{tabular}




\begin{tabular}{|l|l|l|c|c|}
\hline Caso: & \multicolumn{4}{|l|}{ EUA-Foreign Sales Corporation [DS108] } \\
\hline Demandante: & EUA & \multicolumn{4}{l|}{} \\
\hline Demandado: & CE & $\begin{array}{c}\text { Interesse } \\
\text { sistêmico } \\
\text { comerciais }\end{array}$ & $\begin{array}{c}\text { Mera reserva de } \\
\text { direitos }\end{array}$ & $\begin{array}{c}\text { Sem } \\
\text { manifestação }\end{array}$ \\
\hline Terceiras partes: & & & & $\mathrm{X}$ \\
\hline Austrália & & & $\mathrm{X}$ & $\mathrm{X}$ \\
\hline Barbados & & & $\mathrm{X}$ & $\mathrm{X}$ \\
\hline Brasil & & & & $\mathrm{X}$ \\
\hline Canadá & & & $\mathrm{X}$ & \\
\hline China & & & & \\
\hline Índia & & & & \\
\hline Jamaica & & & & \\
\hline Japão & & & & \\
\hline
\end{tabular}




\begin{tabular}{|l|l|l|l|l|}
\hline Caso: & \multicolumn{4}{|l|}{ EUA-Lei Antidumping de 1916(CE) [DS136] } \\
\hline Demandante: & CE & \multicolumn{3}{|l|}{} \\
\hline Demandado: & EUA & $\begin{array}{c}\text { Sem } \\
\text { manifestação }\end{array}$ \\
\hline Terceiras partes: & $\begin{array}{c}\text { Interesses } \\
\text { comerciais }\end{array}$ & $\begin{array}{c}\text { Interesse } \\
\text { sistêmico }\end{array}$ & $\begin{array}{c}\text { Mera reserva de } \\
\text { direitos }\end{array}$ & \\
\hline & & & $\mathrm{X}$ & \\
\hline Índia & & & $\mathrm{X}$ & \\
\hline Japão & & & $\mathrm{X}$ & \\
\hline México & & & & \\
\hline
\end{tabular}




\begin{tabular}{|c|c|c|c|c|}
\hline Caso: & \multicolumn{4}{|c|}{ EUA-Emenda Byrd [DS217] } \\
\hline Demandante: & \multicolumn{4}{|c|}{$\begin{array}{l}\text { Austrália; Brasil; Chile; CE; India; Indonésia; Japão; Coreia do Sul; } \\
\text { Tailândia }\end{array}$} \\
\hline Demandado: & \multicolumn{4}{|c|}{ EUA } \\
\hline Terceiras partes: & $\begin{array}{l}\text { Interesses } \\
\text { comerciais }\end{array}$ & $\begin{array}{l}\text { Interesse } \\
\text { sistêmico }\end{array}$ & $\begin{array}{l}\text { Mera reserva de } \\
\text { direitos }\end{array}$ & $\begin{array}{c}\text { Sem } \\
\text { manifestação }\end{array}$ \\
\hline Argentina & & & & $\mathrm{X}$ \\
\hline Canadá & & & & $\mathrm{X}$ \\
\hline Costa Rica & & & $\mathrm{X}$ & \\
\hline Hong Kong, China & & & $\mathrm{X}$ & \\
\hline Israel & & & $\mathrm{X}$ & \\
\hline México & & & $\mathrm{X}$ & \\
\hline Noruega & & & $\mathrm{X}$ & \\
\hline
\end{tabular}

\begin{tabular}{|c|c|c|c|c|}
\hline Caso: & \multicolumn{4}{|c|}{ EUA-Emenda Byrd [DS234] } \\
\hline Demandante: & \multicolumn{4}{|c|}{ Canadá; México } \\
\hline Demandado: & \multicolumn{4}{|c|}{ EUA } \\
\hline Terceiras partes: & $\begin{array}{l}\text { Interesses } \\
\text { comerciais }\end{array}$ & $\begin{array}{l}\text { Interesse } \\
\text { sistêmico }\end{array}$ & $\begin{array}{c}\text { Mera reserva de } \\
\text { direitos }\end{array}$ & $\begin{array}{c}\text { Sem } \\
\text { manifestação }\end{array}$ \\
\hline Argentina & & & & $X$ \\
\hline Austrália & & & $\mathrm{X}^{*}$ & \\
\hline Brasil & & & $\mathrm{X}^{*}$ & \\
\hline Canadá (parte) & & & $\mathrm{X}^{* *}$ & \\
\hline Chile (removido) & & & $\mathrm{X}^{*}$ & \\
\hline Costa Rica & & & & $\mathrm{X}$ \\
\hline UE & & & $\mathrm{X}^{*}$ & \\
\hline Hong Kong, China & & & & $\mathrm{X}$ \\
\hline Índia & & & $X^{*}$ & \\
\hline Indonésia & & & $\mathrm{X}^{*}$ & \\
\hline Israel & & & & $\mathrm{X}$ \\
\hline Japão & & & $\mathrm{X}^{*}$ & \\
\hline México (parte) & & & $\mathrm{X}^{* *}$ & \\
\hline Coreia do Sul & & & $\mathrm{X}^{*}$ & \\
\hline Noruega & & & & $\mathrm{X}$ \\
\hline Tailândia & & & $\mathrm{X}^{*}$ & \\
\hline
\end{tabular}

* Incluídos pela Presidência por serem terceiras partes em DS217.

** Solicitaram direitos de terceira parte recíprocos, para o caso de painéis separados. 


\begin{tabular}{|c|c|c|c|c|}
\hline Caso: & \multicolumn{4}{|c|}{ EUA-Jogos e Apostas [DS285] } \\
\hline Demandante: & \multicolumn{4}{|c|}{ Antígua e Barbuda } \\
\hline Demandado: & \multicolumn{4}{|c|}{ EUA } \\
\hline Terceiras partes: & $\begin{array}{c}\text { Interesses } \\
\text { comerciais }\end{array}$ & $\begin{array}{l}\text { Interesse } \\
\text { sistêmico }\end{array}$ & $\begin{array}{l}\text { Mera reserva de } \\
\text { direitos }\end{array}$ & $\begin{array}{c}\text { Sem } \\
\text { manifestação }\end{array}$ \\
\hline Canadá & & & $\mathrm{X}$ & \\
\hline Taipé Chinesa & & & $\mathrm{X}$ & \\
\hline UE & & & $\mathrm{X}$ & \\
\hline Japão & & & & $\mathrm{X}$ \\
\hline México & & & $\mathrm{X}$ & \\
\hline China & & & & $\mathrm{X}$ \\
\hline
\end{tabular}




\begin{tabular}{|c|c|c|c|c|}
\hline Caso: & \multicolumn{4}{|c|}{ EUA - Algodão [DS267] } \\
\hline Demandante: & \multicolumn{4}{|c|}{ Brasil } \\
\hline Demandado: & \multicolumn{4}{|l|}{ EUA } \\
\hline Terceiras partes: & $\begin{array}{c}\text { Interesses } \\
\text { comerciais }\end{array}$ & $\begin{array}{l}\text { Interesse } \\
\text { sistêmico }\end{array}$ & $\begin{array}{l}\text { Mera reserva de } \\
\text { direitos }\end{array}$ & $\begin{array}{c}\text { Sem } \\
\text { manifestação }\end{array}$ \\
\hline Argentina & $\mathrm{X}^{* *}$ & $\mathrm{X}^{* *}$ & & \\
\hline Austrália & & & & $\mathrm{X}$ \\
\hline Benin & & & & $\mathrm{X}$ \\
\hline Canadá & & & $\mathrm{X}$ & \\
\hline Chade & & & & $\mathrm{X}$ \\
\hline China & $\mathrm{X}^{*}$ & & & \\
\hline Taipé Chinesa & $\mathrm{X}^{*}$ & & & \\
\hline UE & $X^{*}$ & & & \\
\hline Índia & $\mathrm{X}$ & $\mathrm{X}$ & & \\
\hline Nova Zelândia & & & & $\mathrm{X}$ \\
\hline Paquistão & $\mathrm{X}$ & & & \\
\hline Paraguai & & & & $\mathrm{X}$ \\
\hline Venezuela & & & $\mathrm{X}$ & \\
\hline Japão & & & & $\mathrm{X}$ \\
\hline Tailândia & & & & $\mathrm{X}$ \\
\hline
\end{tabular}

* Expressam concordância com a posição de Índia e Paquistão, sem precisar que tipo de interesse detêm na questão.

** Não menciona interesses comerciais ou sistêmicos, mas declara preocupação com os efeitos negativos no mercado global, e em especial para os países em desenvolvimento, resultantes do nível dos auxílios fornecidos pelos EUA à indústria do algodão. 


\section{ANEXO C}

A Figura abaixo apresenta um exemplo de uma paisagem em que cada ponto do plano ao fundo da figura indica uma específica configuração e a planície acima do plano representa a energia de tal configuração. Os pontos adjacentes da paisagem são aqueles que diferem do alinhamento de cada nação. A paisagem tem uma dimensão para cada país, indicando em qual alinhamento se encontra.

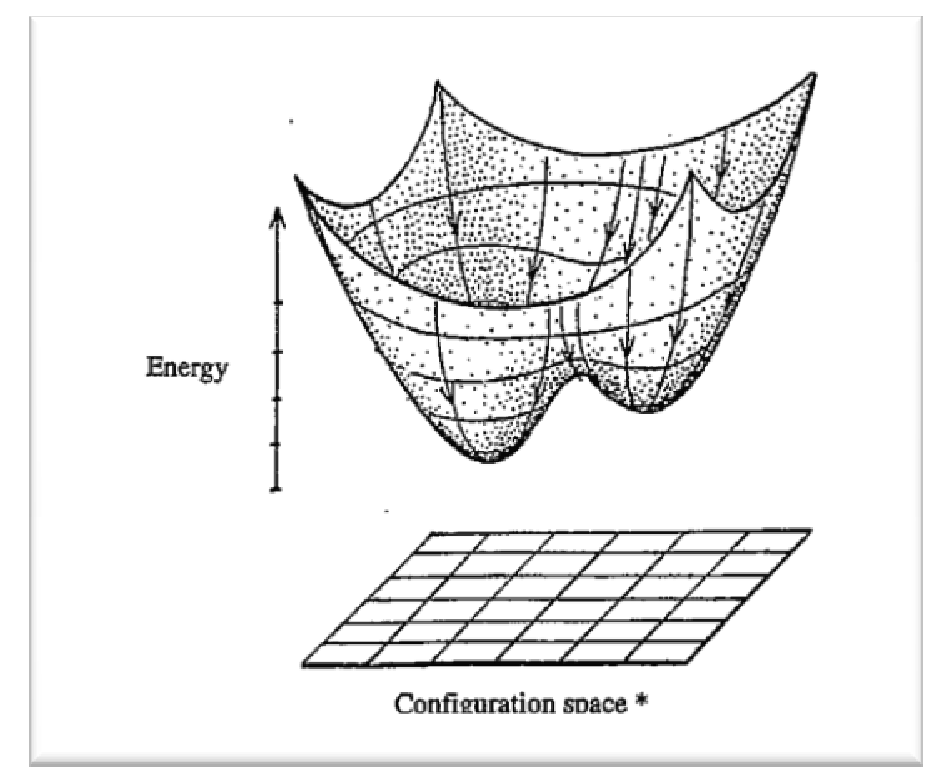

Fonte: Axelrod (1997), p. 77. 


\section{RESUMO}

Esta tese teve por objeto analisar a viabilidade de implementação de, no âmbito do sistema de solução de controvérsias (SSC) da OMC, um mecanismo de contramedidas (retaliação) coletiva, à luz da teoria de formação de alianças, tal qual desenvolvida na teoria de relações internacionais. $\mathrm{O}$ objetivo foi perquirir se e em que condições poderão se formar coalizões visando à aplicação de retaliação coletiva, caso tal mecanismo seja incorporado ao SSC/OMC.

A tese se baseou na premissa de que o enforcement do SSC/OMC ainda se funda em soluções de self-help, ou seja, dependente da força, do poder, do Membro demandante de induzir o Membro demandado a cumprir as recomendações do Órgão de Solução de Controvérsias (OSC), mediante a aplicação de retaliação bilateral, centrada na reciprocidade. Observa-se todavia uma insuficiência e/ou ineficácia de tais contramedidas bilaterais para induzir o Membro demandado a cumprir com as recomendações do OSC em situações envolvendo desequilíbrio de poder (entre Membro demandante e Membro demandado).

A teoria de formação de alianças se mostrou adequada para a análise pretendida, primeiramente porque o desequilíbrio de poder é objeto de estudo de tal teoria. Em segundo lugar, com ênfase na sistematização apresentada por Glenn N. Snyder, tal teoria se mostrou apropriada para a questão em vista da configuração do sistema de comércio internacional como uma anarquia, dentro de uma estrutura de multipolaridade, em que não é possível perceber ex ante os possíveis alinhamentos, diante de uma determinada configuração, justificando o emprego de tal teoria.

A tese então confirmou a necessidade de adoção de um mecanismo de retaliação coletiva no SSC/OMC, tendo indicado quando a retaliação coletiva deverá ser desnecessária, facultativa ou obrigatória. Para tanto, a tese desenvolveu conceitos como "capacidade relativa", "menor coalizão vencedora", "aliança-dependência", além de perquirir sobre a situação pré-aliança dos interesses das unidades envolvidas, como propulsionadora ou limitadora da formação de alianças. Tais conceitos foram aplicados sobre as situações fáticas das onze arbitragens do Artigo 22.6 do Entendimento sobre Solução de Controvérsias (ESC). Por meio da aplicação da Teoria da Paisagem de Agregação, a tese confirmou a necessidade de implementação, em determinadas circunstâncias, de um mecanismo obrigatório de retaliação coletiva.

Assim, propôs a tese que um mecanismo de retaliação coletiva poderá ter caráter meramente facultativo quando, em uma situação de desequilíbrio de poder: (i) houver outros Membros com interesses comuns, intensos e específicos a propulsionar a formação de uma aliança; e (ii) tais Membros reunirem capacidade relativa suficiente para formar uma "menor coalizão vencedora", juntamente com o Membro demandante. De outra parte, o mecanismo de retaliação coletiva deverá ter caráter obrigatório quando, diante de uma situação de desequilíbrio de poder: (i) seja patente a baixa capacidade relativa do Membro demandante; (ii) não haja Membros com interesses comuns, intensos e específicos a propulsionar a formação de uma aliança com o Membro demandante; e (iii) seja improvável a formação de uma "menor coalizão vencedora".

Por fim, a tese apresentou uma proposta de emenda aos Artigos 22.3 e 22.6 do ESC, para incorporação de um mecanismo de retaliação coletiva no SSC/OMC, explicitando os requisitos legais para tanto.

Palavras-chave: OMC; sistema de solução de controvérsias; enforcement; compliance; contramedidas; retaliação; retaliação coletiva; formação de alianças; desequilíbrio de poder. 


\section{ABSTRACT}

The objective of the thesis was to examine the viability of implementing a mechanism of collective countermeasures (retaliation) within the dispute settlement system (DS) of the WTO, as from the perspective of the alliance formation theory, as developed under international relations. The aim was to verify whether and under which conditions coalitions seeking at imposing collective retaliation will form, in case such mechanism is implemented in the DS/WTO.

The thesis developed under the premise that enforcement under the DS/WTO is still founded on self-help, i.e., dependent on the force, the power, of the demanding Members to induce the demanded Member to adopt the Dispute Settlement Body's (DSB) recommendations, by means of bilateral retaliation, based on reciprocity. However, one can note that the insufficiency and/or ineffectiveness of such bilateral countermeasures to induce the demanded Member to comply with the DSB's recommendations are generally associated with imbalance of power situations.

The alliance formation theory proved to be appropriate for undertaking the envisaged analysis. Firstly, the analysis of imbalance of power situations is under the purview of the alliance formation theory. Secondly, with emphasis on the work developed by Glenn N. Snyder, the theory showed to be appropriate for the matter at hand, because the international trade system is structured under anarchy, in a multipolar structure, where it is not possible to predict ex ante the possible alignments in a given configuration, justifying the usage of the theory.

The thesis thus confirmed the need to adopt a mechanism of collective retaliation at the DS/WTO, having indicated that collective retaliation can be unnecessary; allowed or mandatory. For that, the theory developed the concepts of "relative capacity", "minimal winning coalition", "alliancedependence", besides the examination of the pre-alliance situation of the interests of the units involved, to verify whether there are fostering or preventing factors to the alliance formation. Such concepts were applied to the factual settings of the eleven arbitrations of Article 22.6 of the Dispute Settlement Understanding (DSU). By means of the application of the Landscape Theory of Aggregation, the thesis confirmed the need to implement, under certain circumstances, a mandatory mechanism of collective retaliation.

Thus, the thesis submitted that the collective retaliation mechanism will be allowed, when, under an imbalance of power situation: (i) there are other Members with common, intense and specific interests fostering the alliance formation; and (ii) such Members bring about enough relative capacity to form a "minimal winning coalition" with the demanding Member. On the other hand, the collective retaliation mechanism will be mandatory, in an imbalance of power situation, when: (i) it is evident that the demanding Member has low relative capacity; (ii) there are no Members with common, intense and specific interests to foster the formation of an alliance with the demanding Member; and (iii) it is improbable that a "minimal winning coalition" will be formed.

Finally, the thesis proposed an amendment to the text of Articles 22.3 and 22.6 of the $D S U$, to incorporate the collective relation mechanism in the DS/WTO, indicating the legal requisites thereof.

Key-words: WTO; dispute settlement system; enforcement; compliance; countermeasures; retaliation; collective retaliation; alliance formation; imbalance of power. 


\section{ABSTRAIT}

Le but de cette thèse a été l'analyse de le viabilité de l'implémentation, dans le cadre du système de règlement des différends (SRD) de l'OMC, d'un mécanisme de contre-mesures (représailles) collectives, à la lumière de la théorie de formation d'alliances, telle que développée dans la théorie des relations internationales. L'objectif a été de se demander si et dans quelles conditions des coalitions pourrait se former ayant par but l'application des représailles collectives, au cas où ce mécanisme s'incorporait au SRD/OMC.

La thèse s'est basée sur la prémisse selon laquelle l'enforcement du SRD/OMC se base toujours sur des solutions de self-help, c'est à dire, qu'il dépend de la force, du pouvoir, du Membre requérant d'induire le Membre répondant à se conformer aux recommandations de l'Organe de Règlement de Différends (ORD) par la voie de l'application de représailles bilatérales, centrées sur la réciprocité. L'on observe toutefois une insuffisance et/ou inefficacité de telles contre-mesures bilatérales pour induire le Membre répondant à se conformer aux recommandations de l'ORD dans des situations comprenant un déséquilibre de pouvoir (entre Membre requérant et Membre répondeur).

La théorie de formation d'alliances s'est montrée adéquate pour l'analyse ambitionnée, surtout parce que le déséquilibre de pouvoir est le sujet de telle théorie. Ensuite, avec un accent sur la systématisation présentée par Glenn N. Snyder, telle théorie s'est montrée appropriée à la question en vue de la configuration du système du commerce international comme une anarchie, dans une structure de multipolarité, dans laquelle il n'est pas possible d'observer ex ante les possibles alignements, devant une certaine configuration, ce qui justifie l'emploi d'une telle théorie.

La thèse a alors confirmé la nécessité d'adopter un mécanisme de représailles collectives dans l'SRD/OMC, ayant indiqué quand les représailles collectives doivent être non-nécessaires, facultatives ou obligatoires. Pour ce faire, la thèse a développé des concepts comme « capacité relative », « coalition gagnante la plus petite », « alliance-dépendance », examinant par ailleurs la situation pré-alliance des intérêts des unités impliquées, comme moteur ou limite de la formation d'alliances. Ces concepts ont été appliqués sur les situations factuelles des onze arbitrages de l'Article 22.6 de l'Accord sur le règlement des différends (ARD). Par la voie de l'application de la Théorie du Paysage d'Agrégation, la thèse a confirmé la nécessite d'implémentation, dans des circonstances déterminées, d'un mécanisme obligatoire de représailles collectives.

La thèse a proposé qu'un mécanisme de représailles collectives pourra avoir un caractère seulement facultatif lorsque, dans une situation de déséquilibre de pouvoir: (i) il y aura d'autres Membres ayant des intérêts communs, intenses et spécifiques pour donner de l'élan à la formation d'une alliance ; et (ii) ces Membres réuniront la capacité relative suffisante pour former une «coalition gagnante la plus petite », avec le Membre requérant. De l'autre part, le mécanisme de représailles collectives devra avoir un caractère obligatoire lorsque, devant une situation de déséquilibre de pouvoir : (i) la baisse capacité relative du Membre requérant sera évidente ; (ii) il n'y aura pas de Membres avec des intérêts communs, intenses et spécifiques pour donner de l'élan à la formation d'une alliance avec le Membre requérant; et (iii) la formation d'une «coalition gagnante la plus petite » sera improbable.

Finalement, la thèse a présenté une proposition d'amendement aux Articles 22.3 et 22.6 de l'ARD, pour l'incorporation au SRD/OMC d'un mécanisme de représailles collectives, précisant les exigences juridiques pour ceci.

Mots-clés: OMC; système de règlement des différends ; enforcement ; compliance ; contremesures; représailles; représailles collectives; formation d'alliances; déséquilibre de pouvoir. 